UNIVERSIDADE DE SÃO PAULO

FACULDADE DE FILOSOFIA, LETRAS E CIÊNCIAS HUMANAS

DEPARTAMENTO DE LETRAS CLÁSSICAS E VERNÁCULAS

PROGRAMA DE PÓS-GRADUAÇÃO EM FILOLOGIA E LÍNGUA PORTUGUESA

PATRÍCIA SOUZA DA SILVA

\title{
ENSINO DE ARGUMENTAÇÃO EM APOSTILADOS DA REDE PÚBLICA PAULISTA: ENTRE O PRESCRITO E O REAL
}


UNIVERSIDADE DE SÃO PAULO

FACULDADE DE FILOSOFIA, LETRAS E CIÊNCIAS HUMANAS

DEPARTAMENTO DE LETRAS CLÁSSICAS E VERNÁCULAS

PROGRAMA DE PÓS-GRADUAÇÃO EM FILOLOGIA E LÍNGUA PORTUGUESA

\title{
ENSINO DE ARGUMENTAÇÃO EM APOSTILADOS DA REDE PÚBLICA PAULISTA: ENTRE O PRESCRITO E O REAL
}

\author{
Patrícia Souza da Silva
}

Dissertação apresentada ao Programa de Pós-Graduação em Filologia e Língua Portuguesa, do Departamento de Letras Clássicas e Vernáculas, da Faculdade de Filosofia, Letras e Ciências Humanas, da Universidade de São Paulo, para obtenção do título de Mestre em Letras.

Orientadora: $\operatorname{Prof}^{\mathrm{a}} \operatorname{Dr}^{\mathrm{a}}$ Maria Inês Batista Campos 
Autorizo a reprodução e divulgação total ou parcial deste trabalho, por qualquer meio convencional ou eletrônico, para fins de estudo e pesquisa, desde que citada a fonte.

Catalogação na Publicação

Serviço de Biblioteca e Documentação

Faculdade de Filosofia, Letras e Ciências Humanas da Universidade de São Paulo

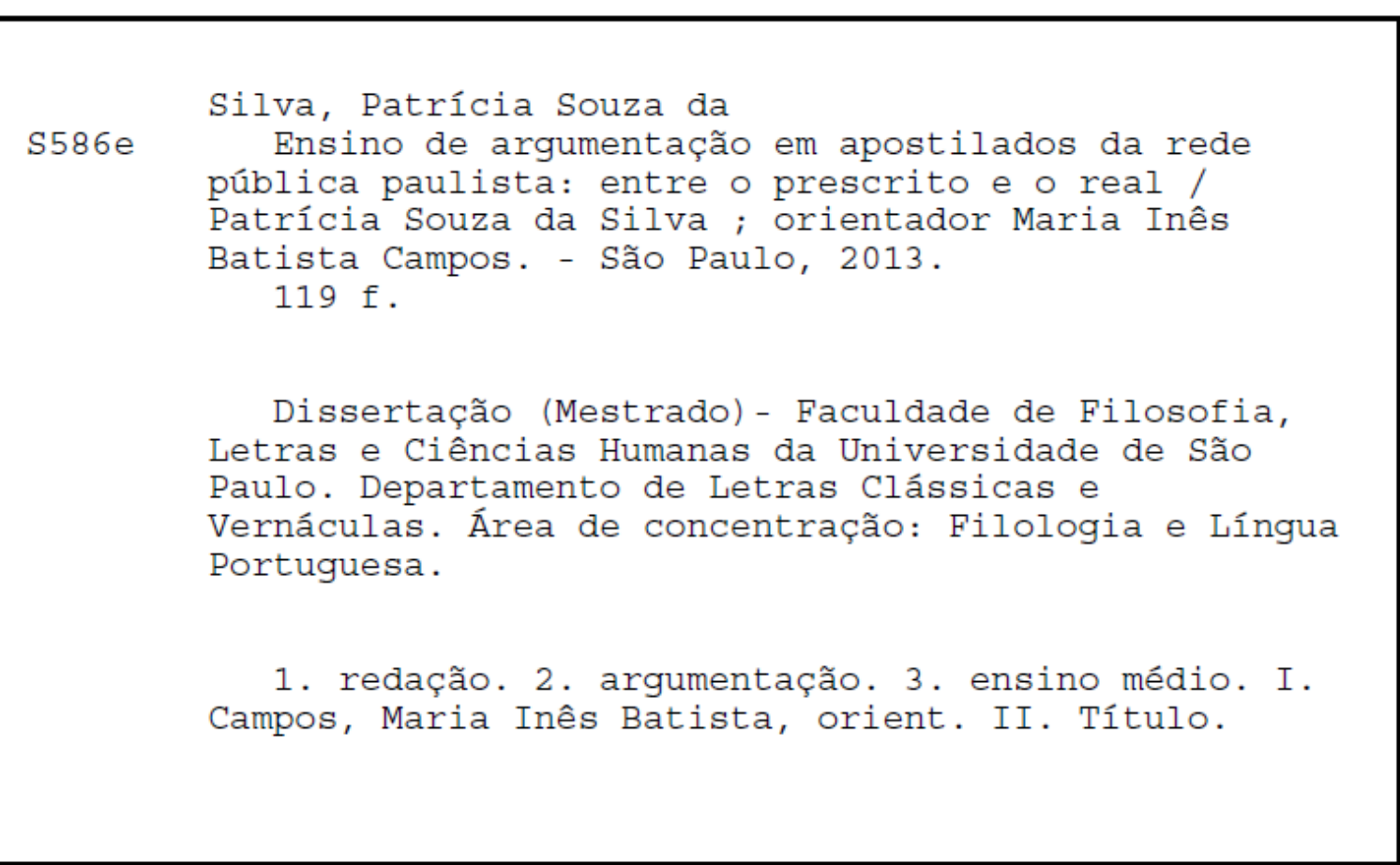


SILVA, Patrícia Souza da. Ensino de argumentação em apostilados da rede pública paulista: entre o prescrito e o real.

Dissertação apresentada ao Programa de Pós-Graduação em Filologia e Língua Portuguesa, do Departamento de Letras Clássicas e Vernáculas, da Faculdade de Filosofia, Letras e Ciências Humanas, da Universidade de São Paulo, para obtenção do título de Mestre em Letras

Aprovada em

Banca Examinadora

$\operatorname{Prof}^{\mathrm{a}} \mathrm{Dr}^{\mathrm{a}}$ Maria Inês Batista Campos Instituição: Universidade de São Paulo Julgamento: Assinatura:

Prof. Dr. Geraldo Tadeu Souza

Julgamento:

Prof $^{\mathrm{a}} \operatorname{Dr}^{\mathrm{a}}$ Zilda Gaspar Oliveira de Aquino Julgamento:
Instituição: Universidade Federal de São Carlos

Assinatura:

Instituição: Universidade de São Paulo Assinatura: 
Aos meus pais, Antonio e Vera, por me ensinarem que o conhecimento é o maior bem do ser humano. 


\section{AGRADECIMENTOS}

Ao Governo do Estado de São Paulo, pelo apoio financeiro dado a esta pesquisa. por meio do Programa Mestrado \& Doutorado.

À Universidade de São Paulo, pelo ambiente de formação acadêmica proporcionado.

À minha orientadora, Maria Inês Batista Campos, pela orientação precisa, generosa e comprometida, desde nossos primeiros encontros até os últimos apontamentos.

À professora Zilda Gaspar Oliveira de Aquino, pela oportunidade de aprendizado, pelo carinho constante e pela confiança em meu potencial.

À professora Beth Brait, pela leitura atenta de meu trabalho e pelas preciosas contribuições dadas em meu exame de qualificação.

Ao professor Geraldo Tadeu Souza, por mostrar-me o rumo bakhtiniano com suas sábias considerações.

Aos professores Clive Thomson e Craig Brandist, por enriquecerem minha formação com os cursos e conferências realizados durante o amadurecimento deste trabalho.

Às professoras Irene Machado, por me acolher em seu curso de verbovisualidade na Escola de Comunicação e Artes da USP, e Sheila Vieira de Camargo Grillo, por ter contribuído para meu aprofundamento no pensamento bakhtiniano.

À Elaine Hernandez de Souza, pela amizade sincera, pelos conselhos e pela valiosa leitura de meu trabalho.

Às companheiras de caminhada, Nanci e Nathália, pelo conforto e amizade.

À querida Mônica, pela contribuição no trabalho de tradução.

À Denísia Moraes, pela revisão criteriosa de meu trabalho.

Aos meus pais e minha irmã, que me incentivaram sempre, sofreram e se alegraram ao meu lado.

Ao meu marido e meu filho, que me apoiaram, acreditaram em mim e aprenderam a entender as minhas ausências.

Aos amigos, de anos e de meses, de longe e de perto, que me deram forças durante todo o processo.

Ao Mestre maior, que permitiu que tudo ocorresse da forma mais perfeita e sublime, que me amparou em minhas quedas e levou-me a dar o passo seguinte. 


\section{RESUMO}

SILVA, Patrícia Souza da. Ensino de argumentação em apostilados da rede pública paulista: entre o prescrito e o real. 2013. 119 f. Dissertação (Mestrado). Faculdade de Filosofia, Letras e Ciências Humanas, Universidade de São Paulo, São Paulo/SP.

Esta dissertação tem como objetivo investigar as propostas de ensino de produção de texto argumentativo, no apostilado de Língua Portuguesa, elaborado pela Secretaria da Educação do Estado de São Paulo, em 2008, e utilizado na rede pública de ensino desde então. Neste trabalho, buscamos (1) descrever o encaminhamento das atividades de ensino de redação de textos argumentativos no apostilado de Língua Portuguesa do Estado de São Paulo, (2) analisar as atividades de produção escrita que abordam o ensino do texto argumentativo (resenha, artigo de opinião e dissertação escolar) e (3) estabelecer o confronto entre as atividades de ensino de redação do texto argumentativo no Caderno do Aluno, as orientações dirigidas ao professor no Caderno do Professor e as prescrições desse conteúdo no Currículo de Língua Portuguesa. Fundamentamos a análise com o apoio teórico do conceito de texto de Bakhtin e o Círculo (1926; 1928; 1929; 1952-53; 1959-61), articulado a outros conceitos do pensamento bakhtiniano - signo ideológico, enunciado e linguagem -, o que contribui para uma concepção da linguagem como atividade humana. Nessa perspectiva, o texto é considerado como uma teia de relações entre textos, que traduzem ações humanas, marcadas social, cultural e historicamente. Recorremos, também, às contribuições do campo de estudos em argumentação denominado Nova Retórica (PERELMAN; OLBRECHTS-TYTECA, 2005), que tratam do conceito de argumentação, dos elementos necessários à argumentação e dos procedimentos argumentativos utilizados na construção da argumentação; elementos que nos auxiliam no aprofundamento da discussão sobre texto argumentativo. Com base nessa fundamentação, descrevemos e analisamos quatro unidades didáticas chamadas Situações de Aprendizagem, presentes em três volumes do apostilado de Língua Portuguesa, composto por doze fascículos, distribuídos aos alunos e professores do Ensino Médio. Nas atividades escolhidas, o ensino do texto argumentativo em três gêneros - resenha (1 ${ }^{a}$ série), artigo de opinião ( $2^{\mathrm{a}}$ série) e dissertação escolar ( $3^{\mathrm{a}}$ série) - e a proposta de escrita nos gêneros mencionados ocorrem pela primeira vez no apostilado de Língua Portuguesa do Ensino Médio. A partir da análise desse objeto de ensino, verificamos que há um embate entre o que está prescrito no Currículo de Língua Portuguesa (2010) e o que, efetivamente, é proposto ao aluno, no que se refere ao conceito de texto e aos conteúdos de ensino do texto argumentativo. Os resultados obtidos mostraram que, no referencial curricular, o texto é considerado como um produto vivo da interação social, e o texto argumentativo deve ser a expressão de um posicionamento crítico diante da sociedade. Nas atividades analisadas, o texto é apresentado como um modelo a ser seguido, favorecendo uma prática escolar pouco voltada à cidadania, e transforma-se em uma tarefa a ser entregue ao professor, na qual o aluno não se constitui como autor, mas como reprodutor de textos. Acreditamos que entre as prescrições e as práticas escolares ainda temos um conhecimento de texto argumentativo genérico e abstrato.

Palavras-chave: texto, argumentação, produção escrita, material didático, apostilado. 


\section{ABSTRACT}

SILVA, Patrícia Souza da. Argumentation teaching in booklets of public school system from São Paulo State: between the prescript and the real. 2013. 119 pages. Dissertation (MA). Faculdade de Filosofia, Letras e Ciências Humanas, Universidade de São Paulo, São Paulo/SP.

This thesis has the purpose to investigate teaching proposals of argumentative texts into Portuguese booklets from Sao Paulo State Ministry of Education, which has been applied in the public school system since 2008. In this study, we aimed (1) to describe writing activities routing, (2) to analyze writing texts that attempt to teaching proposals of argumentative texts (report, text opinion and school essay) and (3) to seek confrontation between teaching activities of argumentative text from the Student's Notebook, the issue guidance to teachers from the Teacher's Notebook, and content prescription inside Portuguese National Curriculum. This theoretical analysis is based on Bakhtin and the Circle Concepts (1926; 1928; 1929; 1952-53; 1959-61) connected to other Bakhtinian concepts - ideological sign, proposition and language - that contribute to a language conception as a human activity. Accordingly, a text is considered a net of relationships between texts translating human actions that are social, cultural and historical marked. We are also based on studies from the argumentative field called New Rhetoric (PERELMAN; OLBRECHTS-TYTECA, 2005) concerning about argumentative concepts, basic elements necessary to argue into and argumentative procedures discussions used to build this specific kind of texts. All of these theories help us to get deeper into argumentative discussion. In this manner, we described and analyzed four didactic units called "Learning Situations", presented on the three volumes of Portuguese Booklet formed by twelve fascicles, distributed to High School teachers and students. In the selected texts, the teaching process of three types of argumentative texts report (First High School), text opinion (Second High School) and school essay (Third High School) happens at first inside the Portuguese High School Booklet. From this educational target analysis, we verified the confrontation between prescribed elements at Portuguese National Curriculum and what effectively is proposed in the classroom referred to contents and concepts of teaching argumentative texts. The results showed that in the Portuguese National Curriculum the text is considered a product of critical placement in front of society. In the analyzed activities, the text is showed as a model to be followed promoting a school practice that is not looking at citizenship process, and it becomes just a task for a teacher where the student is not an author but just a person that is writing something for someone. We believe that between prescription and practice there is a limited and abstract knowledge about the importance of text production.

Key Words: text, argument, writing production, textbook, booklets. 


\section{LISTA DE QUADROS, TABELAS E ESQUEMAS}

Quadro 1 - $\begin{array}{ll}\text { Descrição dos níveis de desempenho em redação } & -37 \\ \text { SARESP }\end{array}$

Quadro 2 - Conteúdos do 1ํㅡ $\quad$ EMrescritos no CLP 45

Quadro 3 - Conteúdos do 2º EM prescritos no CLP

Quadro 4 - Conteúdos do 3ํㅡㄹ prescritos no CLP

Quadro 5 - Reapresentação dos conteúdos de 1ํㅡㄹ EM no CP

Quadro 6 - Reapresentação dos conteúdos de 2º EM no CP 50

Quadro 7 - $\quad$ Reapresentação dos conteúdos de 3ํㅡㄹ no CP

Quadro 8 - $\quad$ Conteúdos de produção escrita 53

Quadro 9 - Composição do objeto de pesquisa

Tabela 1 - Comparativo de desempenho em redação - 3ํㅡㄹ 36

Tabela 2 - Distribuição dos volumes de Língua Portuguesa (EM) Esquema 1 - $\begin{aligned} & \text { Sequência didática das etapas de ensino do texto } \\ & \text { argumentativo no ALP }\end{aligned}$
5

Esquema 2 - $\begin{aligned} & \text { Seções didáticas e etapas de ensino na Situação de } \\ & \text { Aprendizagem "As vozes do outro e a nossa na resenha" }\end{aligned}$

Esquema 3 - Seções didáticas e etapas de ensino na Situação de Aprendizagem "O que faz de alguém um escritor?"

Esquema 4 - Seções didáticas e etapas de ensino na Situação de Aprendizagem "Elaborando um projeto de dissertação"

Seções didáticas e etapas de ensino na Situação de

Esquema 5 - Aprendizagem "Momento de escrita: a redação de acesso 100 ao Ensino Superior" 


\title{
LISTA DE ABREVIATURAS E SIGLAS
}

\author{
ALP - apostilado de Língua Portuguesa \\ CA - Caderno do Aluno \\ CLP - Currículo de Língua Portuguesa \\ CP - Caderno do Professor \\ EM - Ensino Médio \\ ENEM - Exame Nacional do Ensino Médio \\ PCN+ - Orientações Educacionais Complementares aos Parâmetros Curriculares \\ Nacionais
}

PCNEM - Parâmetros Curriculares Nacionais (Ensino Médio)

PISA - Programa Internacional de Avaliação de Estudantes

SAEB - Sistema Nacional de Avaliação da Educação Básica

SARESP - Sistema de Avaliação do Rendimento Escolar do Estado de São Paulo

SPFE - São Paulo Faz Escola 


\section{SUMÁRIO}

INTRODUÇÃO

1 Objeto de pesquisa $\quad 12$

2 Objetivos $\quad 15$

3 Perguntas de pesquisa $\quad 15$

4 Princípios teóricos 16

5 Organização da dissertação 16

\section{CAPÍTULO 1}

Do ensino por correspondência ao Programa São Paulo Faz Escola 18

$\begin{array}{ll}1.1 \text { Sistema de ensino apostilado } & 19\end{array}$

1.2 Programa São Paulo Faz Escola 25

\section{CAPÍTULO 2}

Produção escrita argumentativa no apostilado de Língua Portuguesa: procedimentos metodológicos

2.1 Inserção do ensino de argumentação no Ensino Médio 30

2.2 Composição do objeto de análise 38

2.2.1 Elaboração do apostilado de Língua Portuguesa 38

2.2.2 Composição do apostilado de Língua Portuguesa 38

2.2.3 Organização das Situações de Aprendizagem no Caderno do Aluno

2.2.4 Organização das Situações de Aprendizagem no Caderno do Professor 


\section{CAPÍTULO 3}

Ensino de texto argumentativo no apostilado de Língua Portuguesa

3.1 Texto na concepção de Bakhtin e o Círculo 58

3.2 Texto argumentativo 66

\section{CAPÍTULO 4}

Propostas de produção de textos argumentativos no Caderno do Aluno 73

4.1 Análise A: "As vozes do outro e a nossa na resenha" 74

4.2 Análise B: "O que faz de alguém um escritor?" 82

4.3 Análise C: "Elaborando um projeto de dissertação" 91

4.4 Análise D: "Momento de escrita: a redação de acesso ao Ensino Superior" 99

$\begin{array}{ll}\text { CONSIDERAÇÕES FINAIS } & 106\end{array}$

REFERÊNCIAS

ANEXOS (EM CD) 119 


\section{INTRODUÇÃO}

Nosso estudo está inserido na linha de pesquisa Estudos do Discurso em Língua Portuguesa e vincula-se ao projeto de pesquisa Linguagens e identidades em materiais didáticos de língua portuguesa, liderado pela professora $\mathrm{Dr}^{\mathrm{a}}$ Maria Inês Batista Campos. O grupo de pesquisadores que participa do projeto tem por objetivo estudar práticas de leitura, escrita e oralidade em textos verbais e não-verbais, proposto em livros didáticos e sistemas apostilados de ensino, fundamentando-se na Teoria dialógica do discurso postulada por Bakhtin e o Círculo.

Apresentamos um estudo que trata do ensino de argumentação no sistema de ensino apostilado adotado pela Secretaria da Educação do Estado de São Paulo, desde 2008, composto pela análise de três elementos inter-relacionados no processo de ensino: (1) o documento curricular estadual, denominado Currículo de Língua Portuguesa, publicado em 2010, (2) o material didático direcionado ao professor, intitulado Caderno do Professor, elaborado em 2008 e (3) o material didático usado pelo aluno, Caderno do Aluno, distribuído a partir de 2009. Em nosso estudo, nomeamos o conjunto formado pelos Cadernos do Professor e Cadernos do Aluno como apostilado de Língua Portuguesa.

Nosso objetivo é identificar as relações estabelecidas entre os três componentes do apostilado de Língua Portuguesa (Currículo de Língua Portuguesa, Caderno do Professor e Caderno do Aluno), no que se refere à abordagem dos 
objetos de ensino relacionados ao desenvolvimento de habilidades de leitura e escrita de textos argumentativos.

1 Objeto de pesquisa

Neste trabalho, tomamos por base três componentes do apostilado de Língua Portuguesa da rede de ensino do Estado de São Paulo: (1) os Cadernos do Professor, elaborados em 2008, (2) os Cadernos do Aluno, de 2009 e (3) o Currículo de Língua Portuguesa, consolidado em 2010.

A produção e a adoção desse material integram o plano de ações instituído pelo Governo do Estado de São Paulo em parceria com a Secretaria da Educação, em 2007, baseado na verificação de domínio insuficiente de competências de leitura, escrita e raciocínio lógico-matemático, apresentado por alunos de escolas estaduais em avaliações externas ${ }^{1}$.

A partir desses dados, foi criado o Programa São Paulo Faz Escola, responsável pela implantação de um currículo unificado, o Currículo do Estado de São Paulo (2010), do qual faz parte o Currículo de Língua Portuguesa e a elaboração de um sistema de ensino apostilado próprio, composto pelos Cadernos do Professor, em 2008, e Cadernos do Aluno, em 2009, distribuído aos professores e alunos da rede estadual pública de ensino para que fossem seguidos os mesmos planos de aula em todo o Estado.

Dentre os resultados tomados como base para a adoção de um currículo único e a elaboração do apostilado de Língua Portuguesa, destacamos os dados de avaliação aferidos pelo Sistema de Avaliação do Rendimento Escolar do Estado de São Paulo (SARESP) ${ }^{2}$. Observamos, nesse documento, significativos índices de deficiência no ensino do texto argumentativo, em 2007. Os resultados do SARESP

\footnotetext{
${ }^{1}$ A avaliação externa é um dos principais instrumentos para a elaboração de políticas públicas dos sistemas de ensino e redirecionamento das metas das unidades escolares. $O$ foco é o desempenho da escola, e o resultado é uma medida de proficiência que possibilita a implementação de políticas públicas aos gestores e um retrato do desempenho às unidades escolares.

${ }^{2}$ O SARESP é aplicado pela Secretaria da Educação anualmente desde 1995. Em 2012, foram avaliados os alunos matriculados nos $3^{\circ}, 5^{\circ}, 7^{\circ}$ e $9^{\circ}$ anos do ensino fundamental e na $3^{\text {a }}$ série do ensino médio.
} 
mostraram que apenas $35,6 \%$ dos alunos avaliados apresentaram desempenho adequado no que se refere ao domínio das habilidades de leitura e escrita do gênero avaliado. Averiguamos que 18,2\% mantiveram-se em um patamar considerado insuficiente, 28,4\% apresentavam domínio mínimo das competências leitoras e escritoras esperadas na série em que se encontravam, e, somente, 14,3\% mostravam desempenho avançado no conteúdo avaliado.

O Governo do Estado de São Paulo, em parceria com a Secretaria de Educação, não foi o primeiro a utilizar os apostilados como material didático. $O$ sistema apostilado de ensino teve sua origem na elaboração de apostilas para cursos profissionalizantes a distância, a partir do final da década de 1930. Em 1950, com o aparecimento dos cursos pré-vestibulares, as apostilas foram utilizadas nas salas de aula, e se transformaram em sistemas de ensino estruturados, acompanhando a expansão desses cursos preparatórios nas décadas seguintes. A partir da década de 1990, as escolas públicas municipais do Estado de São Paulo estabeleceram-se como um novo mercado consumidor para as empresas detentoras dos grandes sistemas de ensino, tais como Anglo, Objetivo, COC (SOUZA-E-SILVA, 2012, p. 118).

O ensino do texto argumentativo no Ensino Médio da rede estadual está relacionado ao desenvolvimento de 18 habilidades de leitura e escrita articuladas à tipologia argumentativa. Com o domínio dessas habilidades, apresentadas no Currículo de Língua Portuguesa, espera-se que os alunos tenham condições de escrever textos argumentativos que expressem um posicionamento crítico diante das situações com as quais se deparam.

A tipologia argumentativa é abordada a partir de três gêneros: resenha, artigo de opinião e dissertação escolar. Os gêneros resenha e dissertação escolar são ensinados aos alunos pela primeira vez no Ensino Médio ( $1^{\text {a }}$ série e $3^{\text {a }}$ série, respectivamente). O gênero artigo de opinião começa a ser ensinado aos alunos na última série do Ensino Fundamental II e é retomado na $2^{\underline{a}}$ série do Ensino Médio.

A ênfase no ensino do texto argumentativo no Ensino Médio é dada ao domínio do gênero artigo de opinião, baseado no desenvolvimento de um número de habilidades de leitura e escrita muito maior do que o observado na abordagem dos outros dois gêneros mencionados. Constatamos, nesse material, doze habilidades 
no ensino do artigo de opinião, cinco no ensino da dissertação escolar e apenas uma no ensino da resenha.

Verificamos, assim, que o ensino do texto argumentativo no Ensino Médio pouco contribui no desenvolvimento das habilidades do aluno que decide continuar os estudos. É importante ressaltar que os exames de acesso ao Ensino Superior exigem o domínio da escrita de uma dissertação escolar. Diante da análise do conjunto de dados relacionados à implantação do apostilado de Língua Portuguesa, o destaque ao ensino do artigo de opinião parece-nos uma exigência do exame de avaliação SARESP. Observamos que a escrita de um artigo de opinião aparece nas provas dos alunos concluintes do Ensino Fundamental II e Ensino Médio desde a implantação do Programa São Paulo Faz Escola.

Diante desse quadro complexo, buscamos investigar o tratamento dado a um objeto de ensino específico direcionado a alunos e professores: escrever textos argumentativos.

Em nossa análise, partimos da hipótese inicial de que deve haver consonância existente entre a prescrição do Currículo de Língua Portuguesa, no que se refere ao conceito de texto e conteúdos linguístico-discursivos relativos ao ensino do texto argumentativo e a realização das propostas de escrita de texto argumentativo no material do aluno.

Delimitamos o objeto de pesquisa a quatro atividades didáticas, denominadas Situações de Aprendizagem, presentes em três volumes do Caderno do Aluno, direcionado ao Ensino Médio: "As vozes do outro e a nossa na resenha" (Vol. 3, 1a série do Ensino Médio), "O que faz de alguém um escritor?" (Vol. 1, $2^{\mathrm{a}}$ série do Ensino Médio), "Elaborando um projeto de dissertação" (Vol. 2, $3^{a}$ série do Ensino Médio) e "Momento de escrita: a redação de acesso ao Ensino Superior" (Vol. 2, 3ํㅗㄹ série do Ensino Médio). Nessas atividades, os três gêneros mencionados - resenha, artigo de opinião e dissertação escolar - são abordados pela primeira vez no material didático do Ensino Médio. O texto argumentativo no gênero correspondente a cada série é abordado com exemplos e atividades, e os alunos são levados a produzir um texto no gênero como produto final da Situação de Aprendizagem. 
2 Objetivos

Nosso objetivo principal é investigar as propostas de ensino de redação de texto argumentativo no apostilado de Língua Portuguesa do Estado de São Paulo, no que se refere às prescrições dos conteúdos relativos ao ensino do texto argumentativo.

A partir desse objetivo principal e norteador, estabelecemos três objetivos específicos: (1) descrever o encaminhamento das atividades de ensino de redação de textos argumentativos no apostilado de Língua Portuguesa do Estado de São Paulo; (2) analisar as atividades de produção escrita que abordam o ensino do texto argumentativo (resenha, artigo de opinião e dissertação escolar); (3) estabelecer o confronto entre as propostas de redação de textos argumentativos no Caderno do Aluno, as orientações dirigidas ao professor no Caderno do Professor e as prescrições no Currículo de Língua Portuguesa para esse conteúdo.

\section{Perguntas de pesquisa}

Três perguntas de pesquisa vinculam-se aos objetivos mencionados e direcionam nosso trabalho:

a) As atividades de ensino de texto argumentativo no apostilado de Língua Portuguesa do Estado de São Paulo são suficientes tanto na quantidade quanto no conteúdo para motivar os alunos a escrever textos argumentativos?

b) Que encaminhamento os alunos recebem por meio das Situações de Aprendizagem do apostilado de Língua Portuguesa para que possam ler e escrever textos argumentativos?

c) Os conteúdos linguístico-discursivos relativos à produção de textos argumentativos apresentados no Caderno do Aluno correspondem às prescrições referentes ao ensino de argumentação e de texto argumentativo definidas no Currículo de Língua Portuguesa e reapresentadas no Caderno do Professor? 
4 Princípios teóricos

No estudo proposto, fundamentamos a análise do objeto no conceito de texto conforme as concepções teóricas de Bakhtin e o Círculo (1926; 1928; 1929; 1952-53; 1959-61). Esse conceito articula-se a outros do pensamento bakhtiniano como signo ideológico, enunciado e linguagem. Tal concepção aponta para o estudo da linguagem como atividade humana. Nessa perspectiva, texto não pode ser considerado de maneira isolada, como algo pronto, mas sempre em relação com outros textos, que formam uma cadeia comunicativa viva e mutável. O homem, considerado um ser constituído pela linguagem, tem suas ações traduzidas pelos textos que produz, e, dessa forma, marcam-no social, cultural e historicamente.

Consideramos as noções desenvolvidas pela área de estudos em argumentação denominada Nova Retórica (PERELMAN; OLBRECHTS-TYTECA, 2005) que contribuem para a análise do nosso objeto de pesquisa. : a) conceito de argumentação; b) elementos necessários à argumentação; c) procedimentos argumentativos utilizados na construção da argumentação.

\section{Organização da dissertação}

Organizamos a dissertação em quatro capítulos. No primeiro, intitulado "Do ensino por correspondência ao Programa São Paulo Faz Escola", resgatamos a história dos apostilados, com o intuito de trazer para o leitor um panorama histórico do cenário da educação brasileira a partir da década de 1930, e, dessa forma, oferecer elementos para explicar os discursos que marcaram a época. Além disso, apresentamos o Programa São Paulo Faz Escola, responsável por criar e desenvolver um sistema de ensino apostilado, composto pelos Cadernos do Professor (2008) e pelos Cadernos do Aluno (2009).

No segundo capítulo, intitulado "Produção escrita argumentativa no apostilado de Língua Portuguesa: procedimentos metodológicos”, descrevemos os procedimentos metodológicos para delimitação do objeto de estudo, bem como as razões para a escolha de quatro propostas de produção escrita de textos 
argumentativos nos gêneros resenha, artigo de opinião e dissertação escolar como objeto de pesquisa.

No terceiro capítulo, intitulado "Ensino de texto argumentativo no apostilado de Língua Portuguesa", apresentamos a fundamentação teórica que embasa a análise do objeto, abordando os conceitos de texto, enunciado concreto, língua e linguagem, de acordo com o pensamento bakhtiniano, complementada pelo conceito de argumentação conforme a concepção de argumentação presente na área de estudos Nova Retórica.

No quarto capítulo, intitulado "Propostas de produção de textos argumentativos no Caderno do Aluno", descrevemos e analisamos o encaminhamento metodológico e linguístico-discursivo das Situações de Aprendizagem, escolhidas como objeto de pesquisa, estabelecendo relações entre o que é proposto no Caderno do Aluno (2009) e o que é prescrito no Currículo de Língua Portuguesa (2010) e no Caderno do Professor (2008).

Nas "Considerações finais", apresentamos uma síntese dos resultados obtidos. Procuramos, dessa forma, ainda explicar a hipótese inicialmente formulada, segundo a qual as atividades propostas ao aluno seguem as prescrições do Currículo de Língua Portuguesa, no que se refere ao tratamento dos conceitos relativos ao ensino do texto argumentativo. 


\section{CAPÍTULO 1}

\section{Do ensino por correspondência ao Programa São Paulo Faz Escola}

Considerar o apostilado como um gênero do discurso implica resgatar sua temporalidade e estabelecer os elos com os enunciados que o precederam, de maneira que sua ocorrência na atualidade não seja vista de forma isolada, mas situada em um contexto sócio-histórico real.

Neste capítulo, o objetivo é recuperar a tradição discursiva do apostilado, gênero que agrega posicionamentos ideológicos, transmitidos por meio da materialidade linguística que o constitui como material didático. Na primeira parte do capítulo, resgatamos a tradição de uso das chamadas apostilas, remontando aos anos de 1939 e 1941, com a fundação das primeiras instituições educacionais a utilizar apostilas como base de seu sistema de ensino, Instituto Monitor e Instituto Nacional Brasileiro, passando por sua utilização em cursos pré-vestibulares a partir da década de 1950, até sua maciça presença no panorama das escolas particulares, em um primeiro momento, e públicas desde o final da década de 1990. Em seguida, traçamos o histórico do plano de melhoria da educação paulista iniciado em 2007 pela Secretaria da Educação, o Programa São Paulo Faz Escola (SPFE), do qual faz parte o conjunto de apostilados que integra o objeto de estudo dessa dissertação, com o objetivo de compreender o contexto sócio-histórico no qual os Cadernos do Professor (CP) e Cadernos do Aluno (CA) se inserem. 


\subsection{Sistema de ensino apostilado}

O apostilado passou a ser utilizado como material didático, no Brasil, a partir da fundação do Instituto Radiotécnico Monitor, em 1939, e do Instituto Universal Brasileiro (IUB), em 1941. O Instituto Monitor, considerado o primeiro a utilizar apostilas como recurso didático, foi fundado pelo imigrante húngaro Nicolás Goldberger, que iniciou o Instituto, com a criação de um curso de rádio caseiro, composto por um conjunto de peças e apostilas enviadas pelo correio. Dois anos depois de sua fundação, um de seus sócios se desligou do Instituto e fundou o Instituto Universal Brasileiro (IUB), que seguiu a mesma metodologia de ensino por correspondência.

A fundação das duas instituições, pioneiras no ensino a distância na modalidade correspondência, focadas na formação de mão-de-obra para os setores de indústria e serviços, ocorreu em um cenário histórico específico, com reflexos na educação. Politicamente, o país vivia um regime totalitário, representado pela ascensão de Getúlio Vargas ao poder, por meio de um golpe de Estado, em 1930. Os regimes totalitários eram realidade também em outros países (fascismo na Itália, nazismo na Alemanha, ditadura de Franco na Espanha, e a de Salazar em Portugal), evidenciando marcas de autoritarismo e nacionalismo que culminariam na eclosão da Segunda Guerra Mundial em 1939. (MINOZZI JR., 2007, p. 3)

O fim da República Velha trouxe uma configuração social mais complexa em termos de composição da sociedade. Além da elite, herdeira da aristocracia agrária, havia a classe média, formada principalmente por intelectuais e profissionais, ligados ao comércio e aos serviços nas cidades, e a nascente classe dos operários, que começava o trabalho nas indústrias. O país entrava no processo de industrialização, e era preciso que a educação fornecesse mão-de-obra especializada para essa demanda.

No tocante à educação, importantes mudanças ocorreram, em especial, na organização do ensino secundário. A reforma Francisco Campos (1931) foi responsável pelo reconhecimento oficial do ensino secundário, que passou a ser obrigatório para o ingresso nos cursos superiores, já que até aquele momento havia sido visto apenas como curso preparatório para os exames vestibulares. Além 
disso, o secundário passou a ser organizado em duas etapas: fundamental, com duração de cinco anos, na qual era oferecida uma formação básica e geral; e complementar, com duração de dois anos e formação propedêutica articulada ao Ensino Superior, uma vez que os estudantes optavam entre o curso pré-jurídico, o curso pré-médico e o curso pré-politécnico. Segundo Zotti (2006, p. 4), o caráter enciclopédico dos programas e o alto nível de exigência de aprovação no curso secundário tornaram o ensino acessível somente à elite.

A partir de 1942, a promulgação das Leis Orgânicas do Ensino, iniciativa do Ministro da Educação e Saúde Pública Gustavo Capanema, ocasionou novas modificações à estrutura do ensino secundário e do ensino técnicoprofissionalizante. $O$ curso complementar foi extinto e o secundário passou a ser organizado em dois ciclos. O primeiro, formado pelo curso ginasial, com duração de quatro anos, tinha por objetivo oferecer uma formação básica aos estudantes do ensino secundário. O segundo ciclo era composto por dois cursos paralelos: o científico e o clássico, ambos com duração de três anos. O curso científico aprofundava os estudos na área de ciências; o clássico voltava-se para o estudo das letras antigas. Ao término do secundário, o estudante estava apto a prestar os exames vestibulares e continuar a formação no Ensino Superior. Aos estudantes que não pretendiam cursar o Ensino Superior, ou que não conseguiam resultado satisfatório nos exames de admissão para o curso secundário, havia a opção por cursar um dos cursos do ensino profissional, dividido em normal, agrícola, industrial e comercial, com ingresso direto no mercado de trabalho (ZOTTI, 2006, p. 4-5).

Em outras palavras, o dualismo entre o ensino propedêutico, direcionado às elites, ingressantes no Ensino Superior, e o ensino técnico-profissionalizante, direcionado às camadas populares, principal força de trabalho, se fortalecia. Esse ensino por correspondência propagado pelo Instituto Monitor e pelo Instituto Universal Brasileiro constituiu-se como mais uma forma de preparar mão-de-obra que atendesse à demanda do processo de industrialização. As apostilas, preparadas de maneira igual e enviadas para alunos do Brasil inteiro, contribuíram para a instauração de um processo pedagógico que deixou de lado a reflexão, caracterizando-se pela massificação de conteúdos.

As apostilas adentraram também as salas de aula de cursos presenciais a partir da década de 1950. Em um primeiro momento, foram utilizadas nos cursos 
pré-vestibulares, surgidos com o aumento da demanda por ingresso no Ensino Superior, e mais tarde, a partir da década de 1980, em escolas particulares que adotaram o apostilado como sistema de ensino (CÁRIA; ANDRADE, 2011, p. 4; CARVALHO; COSTA, 2009, p. 2; MOTTA, 2002, p. 82).

Na década de 1950, segundo Whitaker (2010, p. 291), o número de candidatos ao Ensino Superior já ultrapassava a quantidade de vagas oferecidas, 0 que motivou a necessidade de preparação dos candidatos por meio de cursos. De seu surgimento até a década de 1960, os cursinhos eram modestos e se resumiam a pequenas salas de aula mantidas por professores que ministravam cursos de revisão das disciplinas exigidas nos exames vestibulares.

Com a democratização do ensino, ocorrida na década de 1960, que respondia aos planos de desenvolvimento econômico do governo ditatorial brasileiro, houve um aumento vertiginoso na exigência por escolarização, tanto no ensino de $2^{\circ}$ grau quanto no Ensino Superior. Entretanto, a oferta de cursos superiores nas universidades públicas não acompanhou esse crescimento (NETTO, 1985, p. 43).

Muitos alunos que passavam no exame não conseguiam vagas. De acordo com Martins (2009, p. 19), em 1960, 29 mil estudantes aprovados nos exames vestibulares não puderam ingressar na universidade por falta de vagas. Nove anos depois, esse número subia para 162 mil. Para sanar essa questão, o governo militar reestruturou o Ensino Superior, incentivando a abertura de faculdades particulares que pudessem absorver os "excedentes", como ficaram conhecidos os candidatos aprovados que não conseguiam vagas.

A assinatura do Decreto 5.540, em 1968, introduziu modificações ao processo de ingresso nas universidades: a) extinção das provas escritas, substituídas por testes objetivos de múltipla escolha, possibilitando maior rapidez e objetividade na correção das provas; b) alteração do caráter habilitatório do exame para classificatório; c) unificação do vestibular, permitindo aos estudantes concorrer às vagas oferecidas por todas as unidades de Ensino Superior por meio da realização de uma única prova; d) revisão dos programas de vestibulares, incluindo conteúdos das áreas de Ciências Humanas e Literatura (NETTO, 1985, p. 44-45).

Essas medidas tornaram os exames vestibulares ainda mais concorridos, uma vez que apenas os candidatos com melhor classificação conseguiam uma vaga 
no Ensino Superior. Nesse período, o Curso Anglo-Latino e o Curso Objetivo despontaram como os principais cursos preparatórios para vestibulares, inovando na confecção de fascículos teóricos, simulados e resolução comentada de questões de vestibulares, absorvendo os pequenos cursos preparatórios e transformando-se, aos poucos, em grandes conglomerados empresariais (WHITAKER, 2010, p. 4).

Nas décadas de 1970 e 1980, o sistema apostilado de ensino sistematizado pelos cursos preparatórios para os vestibulares passou a ser usado também nas aulas do Ensino Médio, com a criação do Colégio Objetivo e a produção de material didático pelo Curso Anglo a escolas conveniadas. A articulação entre colégios particulares, cursos pré-vestibulares e cursos universitários fortaleceu ainda mais o apostilado como sistema de ensino, uma vez que, a cada ano, mais alunos oriundos de cursos pré-vestibulares e colégios com sistemas de ensino apostilados ingressavam no Ensino Superior. Whitaker (2010, p.3) denomina esse fenômeno como "efeito cursinho", conceito formulado a partir da análise de dados de candidatos ao vestibular da Universidade Estadual Paulista - VUNESP, realizada em duas etapas; a primeira, em 1989; e a segunda, em 1999. A comparação dos dados dos dois grupos de candidatos permitiu verificar que uma grande porcentagem de ingressantes nesse vestibular havia frequentado um curso pré-vestibular por, pelo menos, um ano.

Na visão de Motta (2001, p. 85-86), a escola estruturada sobre um sistema apostilado de ensino partilha das mesmas concepções político-econômicas da sociedade dos anos 1980: manutenção do capitalismo, progresso econômico e modernização. Essas concepções foram calcadas no imaginário social a partir dos anos 1950, com o Plano de Metas, proposto pelo então presidente da República, Juscelino Kubitschek de Oliveira, e reforçado ao longo de todo o período da ditadura militar, em que a educação visava à instrumentalização e adequação de cada um ao mercado de trabalho.

Na década de 1990, a essa visão capitalista somou-se o fenômeno da globalização e a revolução tecnológica da Internet. O mundo do trabalho exigia racionalização, eficiência, informação e rapidez, e a escola precisou se adaptar a esse novo paradigma. As parcerias público-privadas surgiram, em especial, no estado de São Paulo, consistindo no estabelecimento de uma relação entre o setor privado e o poder público, o que possibilitou a intervenção de empresas privadas em 
determinado assunto de responsabilidade da administração pública (BEZERRA, 2008, p. 62-63). No caso dos municípios paulistas que aderiram a essa prática, a municipalização do Ensino Fundamental, iniciada em 1996, no Governo Mário Covas (1995-1998), é considerada por pesquisadores da área de Políticas Públicas como fator preponderante para o estabelecimento dessa parceria, uma vez que a administração pública não dispunha dos meios para o atendimento das demandas educativas assumidas (ADRIÃO et. al., 2009; NICOLETI, 2009; BRITTO, 2011; CUNHA, 2011).

O suporte dado pelo setor privado traduziu-se na compra de sistemas de ensino estruturado, compostos pelo fornecimento de apostilas e materiais didáticos para alunos e professores, capacitação docente e treinamento em serviço, além de acompanhamento pedagógico de utilização do material (ADRIÃO et. al., 2009, p. 801-802).

A adoção do sistema apostilado gera controvérsia, de acordo com Britto (2011, p. 14-16). Dentre os aspectos positivos, a pesquisadora cita o posicionamento das equipes gestoras: a) a estrutura do apostilado, com sequências didáticas claras e planejamento aula a aula, permite um maior controle e monitoramento do trabalho docente; b) a uniformidade de conteúdos e as orientações claras aos professores possibilitam a garantia de um padrão mínimo de qualidade a todos os alunos, de maneira a suprir eventuais deficiências na formação inicial dos docentes; c) a oferta de ferramentas complementares à equipe docente (treinamentos, recursos pedagógicos disponibilizados por meio eletrônico, assessoria pedagógica) assegura a condução das atividades propostas.

Como aspectos negativos, Britto (2011, p. 14-16) aponta: a) ausência de avaliação externa, o que pode acarretar na ocorrência de problemas conceituais e abordagens pedagógicas descontextualizadas; b) diminuição da autonomia do professor, que tem sua aula presa a um roteiro rígido de aulas; c) custo do material, subsidiado inteiramente pelo município, com gasto médio de 150 reais por aluno anualmente.

A despeito das opiniões conflitantes, o número de municípios paulistas conveniados ao setor privado no campo educacional aumenta a cada ano. Em 2008, cerca de $23 \%$ dos municípios paulistas adotavam um sistema de ensino apostilado. 
Em 2011, 44\% dos municípios já haviam realizado esse convênio. A tendência é de crescimento, e editoras, que preparavam o material apenas para escolas particulares, passaram a organizar sistemas apostilados direcionados às redes públicas, como as Editoras Saraiva e Moderna (VIALLI, 2011).

Duas consequências da utilização de sistemas apostilados de ensino podem ser citadas. A primeira refere-se à criação de um currículo independente e paralelo aos referenciais curriculares nacionais, que são colocados em segundo plano. Cada sistema apostilado organiza planos de aula, conteúdos mínimos e metodologia próprios, interferindo na quantidade de aulas de cada disciplina, na rotina escolar e na identidade da escola (CUNHA, 2011, p. 602-603). A segunda relaciona-se à fragmentação do conhecimento, apresentado nas apostilas em forma de aulas a serem cumpridas, com textos esquemáticos e resumos, preparados pelos próprios autores dos apostilados, com pouco ou nenhum espaço para a discussão e reflexão de ideias (MOTTA, 2001, p. 87).

A adoção de sistemas apostilados de ensino constitui-se, na visão de Carvalho Neto (2004, p. 1-2), como uma tecnologia desenvolvida na primeira metade do século XX a fim de responder às demandas educacionais vigentes, a qual o autor denomina "técnica do apostilismo" e assim comenta:

\begin{abstract}
Se, por um lado, a técnica do apostilismo vinha para resolver um problema logístico e definia uma metodologia, isto é, um caminho próprio, por outro podemos questionar 0 impacto educacional que esta concepção potencializava. De fato, o modelo educacional inaugurado pelo apostilismo propiciava a gestão de processos de ensino-aprendizagem calcados na "decoreba" ou, quando muito, alicerçados numa lógica interna precisa, mas totalmente desvinculada das vivências pessoais do estudante e, ainda menos, de seu cotidiano cultural (CARVALHO NETO, 2004, p. 2).
\end{abstract}

No Estado de São Paulo, a Secretaria da Educação criou um sistema de ensino apostilado próprio por meio do Programa São Paulo Faz Escola (SPFE), a fim de sanar as dificuldades apresentadas pelos alunos concluintes do Ensino Fundamental (EF) e Ensino Médio (EM), aferidas em avaliações externas, como o SARESP, o Sistema Nacional de Avaliação da Educação Básica (SAEB) ${ }^{3}$, o Exame

\footnotetext{
${ }^{1}$ O SAEB, criado em 1990 e reformulado em 1995, é composto por duas avaliações complementares, a Avaliação Nacional da Educação Básica (Aneb) e a Avaliação Nacional do Rendimento Escolar (Anresc)/Prova Brasil, que são realizadas a cada dois anos. A Aneb é aplicada a amostras de alunos
} 
Nacional do Ensino Médio (ENEM) ${ }^{4}$ e o Programme for International Student Assessment - Programa Internacional de Avaliação de Estudantes (PISA ${ }^{5}$. Essa medida fez parte de um Plano Estadual da Educação, elaborado em 2007, segundo o qual dez metas deveriam ser atingidas até 2010, com foco na melhoria da qualidade do ensino público (FIAMENGUI, 2009, p. 60; CUSTÓDIO, 2010, p. 42; ANDRADE SILVA, 2010, p. 22; ROSSI, 2011, p. 40-44; CASSIARI, 2011, p. 17; 37 40).

A seguir, apresentamos o histórico do Programa SPFE, com o intuito de mostrar o estabelecimento do Currículo do Estado de São Paulo, referencial curricular que apresenta os conteúdos mínimos e a grade de competências e habilidades a serem desenvolvidas no EF II e EM, válidos para todo o estado. Também são apresentados os Cadernos do Professor (CP) e os Cadernos do Aluno $(C A)$, conjunto de apostilados que subsidiam a implementação do Currículo nas escolas, por meio dos quais professores e alunos da rede tomam contato com as atividades didáticas elaboradas em consonância com a grade curricular prescrita.

\subsection{Programa São Paulo Faz Escola (SPFE)}

O Programa SPFE foi criado em 2007, durante o governo José Serra, sob a orientação da então Secretária da Educação Maria Helena Guimarães de Castro. O programa consistiu na implantação de um currículo pedagógico único em todas as escolas da rede estadual, direcionado aos alunos do EF II e EM, com o objetivo de melhorar a qualidade da educação paulista. O currículo, intitulado Proposta Curricular do Estado de São Paulo, em 2008, e Currículo do Estado de São Paulo depois de sua consolidação, em 2010, está fundamentado nos documentos e publicações institucionais já existentes (Parâmetros Curriculares Nacionais, 1998; Parâmetros Curriculares Nacionais: Ensino Médio, 2000; Orientações Curriculares para o Ensino Médio, 2006), e na consulta e análise de práticas pedagógicas de

matriculados nos 5ํ e 9a anos do EF e na 3a série do EM. A Prova Brasil é direcionada a todos os alunos matriculados nos anos finais dos dois ciclos do Ensino Fundamental (5 e 9ำ anos).

${ }^{4}$ O ENEM, criado em 1998, avalia a qualidade da educação no Ensino Médio em nível nacional.

5 O PISA é uma avaliação internacional padronizada, desenvolvido conjuntamente pelos países participantes da Organização para a Cooperação e Desenvolvimento Econômico (OCDE), aplicada a alunos de 15 anos. Suas avaliações são realizadas a cada três anos e abrangem as áreas de Linguagem, Matemática e Ciências. 
sucesso em escolas da rede para a seleção dos conteúdos, competências e habilidades mínimas, comuns aos alunos da rede estadual. Para a implementação da Proposta nas salas de aula, foram elaborados os Cadernos do Professor $(C P)$ e os Cadernos do Aluno (CA), um sistema de ensino apostilado próprio, que apresentava a professores e alunos o currículo prescrito por meio de atividades didáticas.

Cinco ações principais foram realizadas pelo Programa SPFE a fim de implantar o currículo único: a) recuperação de conteúdos, realizada no início do ano letivo de 2008; b) elaboração da Proposta Curricular do Estado de São Paulo e dos Cadernos do Professor, distribuídos no início de 2008; c) vinculação dos conteúdos apresentados na Proposta Curricular ao SARESP, a partir da avaliação realizada em 2008; d) elaboração e distribuição dos Cadernos do Aluno, em 2009; e) consolidação do Currículo do Estado de São Paulo (2010).

A primeira ação do Programa SPFE foi a realização de uma recuperação de conteúdos nos primeiros 42 dias do ano letivo de 2008, com base na utilização de um jornal elaborado, especialmente, para uso em sala de aula. Todos os alunos da rede receberam O Jornal do Aluno São Paulo Faz Escola, que continha as atividades a serem desenvolvidas em todas as disciplinas, agrupadas em dois blocos. No primeiro bloco, as atividades de Língua Portuguesa, Língua Inglesa, Artes, História e Educação Física priorizaram o desenvolvimento de habilidades de leitura e escrita; no segundo bloco, as atividades de Matemática, Geografia e Ciências enfocaram o cálculo matemático, principais deficiências aferidas nas avaliações externas realizadas anteriormente. As Revistas do Professor foram distribuídas apenas aos docentes, com orientações sobre como desenvolver as atividades propostas no Jornal do Aluno São Paulo Faz Escola.

Terminado o ciclo de recuperação intensiva, os professores receberam a Proposta Curricular e o CP, conjunto de apostilas organizadas por bimestre e por disciplina, contendo, a exemplo da Revista do Professor, as orientações didáticas, planos de aula, bem como as atividades a serem desenvolvidas com os alunos, sugestões de avaliação e recuperação.

O CA foi distribuído nas escolas somente em 2009, após relatos de dificuldades enfrentadas pelos professores na condução das atividades propostas 
sem que os alunos tivessem qualquer tipo de material. Organizados em apostilas bimestrais para cada disciplina, o CA trazia atividades e exercícios para trabalho em sala de aula.

Outra ação prevista pelo Programa SPFE foi a ligação dos conteúdos prescritos na Proposta Curricular à grade de competências e habilidades requisitada nas avaliações do SARESP, que passou a ser a base para as ações de gestão da Secretaria da Educação, influenciando não apenas a mobilização de políticas públicas de melhoria educacional, mas também o sistema de bonificação dos professores da rede, vinculado aos resultados da avaliação, por meio da implantação do Programa de Qualidade da Escola.

Por meio desse programa, os resultados atingidos no SARESP foram combinados aos índices de repetência e evasão de cada escola para criar o Índice de Desenvolvimento da Educação do Estado de São Paulo (IDESP), um indicador de qualidade das séries iniciais e finais do EF e do EM, que tem como objetivo fornecer um diagnóstico de cada segmento da escola, mostrando os pontos a serem melhorados, e propor uma meta anual a ser atingida, calculada com base no desempenho aferido no SARESP e no fluxo escolar (SÃO PAULO, 2012).

Em 2010, com o Secretário da Educação Paulo Renato Souza, ex-Ministro da Educação do governo Fernando Henrique Cardoso (1995-2002), a Proposta Curricular foi reformulada e publicada como versão definitiva, com o título Currículo do Estado de São Paulo, organizado em quatro volumes, cada um direcionado a uma das áreas do conhecimento. A grade mínima de conteúdos e expectativas de aprendizagem referente a cada série, até aquele momento proposta aos professores, tornou-se prescrição, conduzindo o trabalho docente.

O Currículo de Língua Portuguesa (CLP) encontra-se no volume dirigido à área de Linguagens, Códigos e suas Tecnologias, e compõe-se de quatro partes: a) "O ensino de Língua Portuguesa: breve histórico" - panorama histórico do ensino da disciplina de Língua Portuguesa no Brasil, evidenciando o diálogo estabelecido entre esse referencial curricular e os documentos oficiais precedentes; b) "Fundamentos para o ensino de Língua Portuguesa" - apresentação da concepção da disciplina para o EF II e EM e dos fundamentos teóricos que embasam essa concepção; c) "Língua Portuguesa para o Ensino Fundamental (Ciclo II) e Ensino Médio" - 
organização da disciplina no EF II e no EM, com subdivisão em tópicos que abordam os conteúdos básicos desses dois ciclos de ensino, a metodologia de ensinoaprendizagem desses conteúdos, os subsídios para a implementação do CLP e a ligação dos conteúdos básicos às habilidades que devem ser desenvolvidas; d) "Quadro de conteúdos e habilidades em Língua Portuguesa" - tabela organizada por série e dividida em bimestre com os conteúdos e as habilidades que devem ser desenvolvidos (SÃO PAULO, 2010, p. 28-104).

Um dos conceitos centrais no CLP é o de língua e linguagem, que se interrelacionam. A língua é considerada em seu uso efetivo e vivo, interligada às condições sociais de sua realização e aos sujeitos participantes de cada situação de comunicação, contribuindo para que a linguagem seja vista como "uma atividade social, um espaço de interação entre pessoas, num determinado contexto de comunicação" (SÃO PAULO, 2010, p. 31).

Outro conceito importante é o de texto, considerado o centro das aulas de português, entendido como "totalidade semiótica de sentido constituída por uma combinação de linguagens e operações aplicadas ao fluxo de uma produção semiótica concreta" (SÃO PAULO, 2010, p. 32). Em outras palavras, nessa concepção, um texto pode ser verbal, visual ou verbo-visual, e seu estudo está conectado ao estudo dos tipos e gêneros textuais, definidos no referencial curricular estadual como:

\footnotetext{
TIPO

Composição linguística que organiza - pela predominância em um texto os diferentes gêneros textuais.

GÊNERO

Evento linguístico social que organiza os textos a partir de características sociossemióticas: conteúdos, propriedades funcionais, estilo e composição estrutural. (SÃO PAULO, 2010, p. 32)
}

A apresentação dos conceitos que fundamentam a disciplina de Língua Portuguesa permite concluir que a abordagem adotada nos apostilados da rede estadual leva em consideração a língua em consonância com a situação de comunicação, considerando os parceiros da interlocução como sujeitos. Esse posicionamento é considerado um avanço, na medida em que dialoga com as mais recentes teorias linguísticas, nas quais os interlocutores são centrais no processo de comunicação. 
Os apostilados são formados por dois materiais pedagógicos: o $C P$ e o $C A$, o que leva o estabelecimento de um diálogo entre três interlocutores: a Secretaria da Educação, na posição de autor do apostilado, o professor e o aluno, na posição de receptores. Ao professor são dados não apenas os conteúdos mínimos exigidos pelo currículo unificado, mas as sequências didáticas completas para o trabalho em sala de aula. Ao aluno é dada uma versão com as atividades, que compreendem textos para leitura, perguntas e exercícios. $\mathrm{O}$ diálogo entre o $C P$ e o $C A$ se estabelece, na medida em que essas apostilas apresentam os mesmos conteúdos, direcionados a leitores distintos, o que acarreta encaminhamentos específicos a cada destinatário. No entanto, o processo de interação se dá em apenas uma via, da Secretaria da Educação para os professores e alunos, pois as prescrições do currículo e a vinculação do apostilado a uma avaliação externa, na qual a aprendizagem dos conteúdos e habilidades prescritas é cobrada, desmotivam a ocorrência de mudanças na condução das atividades, seja por parte do professor, ou do aluno.

Por outro lado, as mesmas razões que levam à massificação do trabalho docente podem ser vistas como benefício. A organização de conteúdos mínimos e o fornecimento de atividades sistematizadas, nos apostilados, estruturam o trabalho escolar e conectam-no à avaliação da própria escola e da equipe docente, que participa mais ativamente dos processos de formação continuada.

Estabelecemos o histórico de utilização de apostilados como sistemas de ensino, bem como apresentamos os aspectos positivos e negativos de sua utilização, desde o ensino por correspondência, passando pelas apostilas de cursos pré-vestibulares e chegando aos apostilados utilizados nas redes particulares e públicas. No capítulo seguinte, apresentamos os critérios de escolha e delimitação do objeto de pesquisa, a partir dos conteúdos apresentados no CLP. 


\section{CAPÍTULO 2}

\section{Produção escrita argumentativa no apostilado de Língua Portuguesa: procedimentos metodológicos}

Neste capítulo, o objetivo é apresentar os procedimentos metodológicos para a delimitação do objeto de pesquisa. Organizamos o capítulo em três partes. Na primeira parte, apresentamos a relevância do ensino de argumentação no Ensino Médio (EM), justificando a escolha do apostilado de Língua Portuguesa (ALP) da rede pública estadual e dos conteúdos de produção escrita argumentativa como objeto de investigação. Na segunda parte, descrevemos o apostilado de Língua Portuguesa (ALP) do ponto de vista formal, apresentando sua composição e a organização das unidades didáticas que o constituem. Na terceira parte, elencamos os conteúdos prescritos pelo Currículo de Língua Portuguesa (CLP) para o Ensino Médio (EM), a partir dos quais foram selecionados os objetos de ensino referentes à produção argumentativa.

2.1 Inserção do ensino de argumentação no Ensino Médio

O apostilado de Língua Portuguesa (ALP) elaborado pela Secretaria da Educação tem sido utilizado, desde 2008, na rede pública de ensino do Estado de São Paulo, considerado o mais populoso do país. Sua abrangência e consequente relevância no panorama educacional do estado motivaram nossa escolha por analisá-lo, visto que os apostilados são utilizados por $84,94 \%$ dos alunos 
matriculados na rede paulista no Ensino Médio (EM) e 74,73\% dos professores dessa etapa de ensino em 62,58\% das escolas (BRASIL, 2012).

Duas razões motivaram a seleção de conteúdos relacionados ao ensino do texto argumentativo: a) o Governo do Estado de São Paulo considera que o ensino de argumentação é relevante, conforme observado no $C L P$; b) na avaliação externa SARESP, verifica-se a dificuldade dos alunos concluintes do Ensino Médio (EM) em dominar plenamente as competências de escrita do texto argumentativo, conforme dados compilados das avaliações SARESP desde 2007, ano anterior à implementação do Programa SPFE, até 2011, data do último resultado oficial da avaliação.

\section{A argumentação nos referenciais curriculares nacionais}

O ensino de produção de textos argumentativos tem relevância marcada para o Ensino Médio (EM) dada ao desenvolvimento das competências ligadas à construção da argumentação, observado nos três referenciais curriculares nacionais já existentes, voltados ao EM, produzidos entre 2000 e 2006, e que serviram de base à elaboração do CLP (2010): Parâmetros Curriculares Nacionais (Ensino Médio) - Linguagens, Códigos e suas Tecnologias (PCNEM, 2000), Orientações Educacionais Complementares aos Parâmetros Curriculares Nacionais ( $P C N_{+}$, 2002) e Orientações Curriculares para o Ensino Médio (2006).

Nesses documentos, o domínio de conteúdos formais passou a ser apenas um dos aspectos considerados na mobilização de recursos cognitivos necessários à resolução de situações-problema, com ênfase na aquisição de competências e habilidades necessárias à vida em sociedade e ao exercício da cidadania (BRASIL, 1998). As competências são entendidas como um conjunto de atitudes e procedimentos tomados frente a cada situação com que se depara o indivíduo.

Os PCNEM (2000) delimitam a área de conhecimento e estabelecem o domínio da linguagem como primordial para o desenvolvimento de competências. A linguagem é considerada como "a capacidade humana de articular significados coletivos e compartilhá-los em sistemas arbitrários de representação, que variam de 
acordo com as necessidades e experiências da vida em sociedade" (BRASIL, 2000, p. 5), por isso, é transdisciplinar e está presente em todas as disciplinas.

O documento apresenta os novos paradigmas da disciplina de Língua Portuguesa adotados na relação de ensino-aprendizagem, deixando de lado a divisão Língua e Literatura e enfatizando a interdisciplinaridade. A concepção de língua adotada no documento estabelece o texto como centro da aula de português, entendido não mais em virtude de suas características tipológicas, mas como um produto da interação social (BRASIL, 2000, p. 17).

Nos PCNEM, o ensino da argumentação propõe que o aluno compreenda a língua, avalie e interprete 0 ato interlocutivo. Além disso, saiba julgar e tomar posição perante os diversos textos em circulação a partir da compreensão e a reflexão sobre a posição social dos interlocutores, do contexto extraverbal, da escolha do gênero adequado à situação e dos recursos linguísticos pertinentes (BRASIL, 2000, p. 21-22). Não há indicações a respeito do que, especificamente, deve ser trabalhado com os alunos ou como isso deve ser realizado.

Os PCN+ (2002) destinam-se a apresentar a professores uma articulação dos conhecimentos das disciplinas agrupadas em áreas de conhecimento. A segunda parte do documento caracteriza a área de Linguagens, Códigos e suas Tecnologias e explicita a incorporação da abordagem centrada no domínio de competências, aliada à aquisição de conceitos e ao desenvolvimento de habilidades.

No documento, o trabalho com a argumentação está ligado ao desenvolvimento da habilidade de emitir juízos críticos sobre manifestações culturais, em que se prioriza a formulação de opiniões sustentadas por argumentos como requisito para a construção de posicionamentos críticos (BRASIL, 2002, p. 72 74). A identificação de tese e de argumentos, a seleção de argumentos para corroborar a tese, a análise da pertinência das informações para a construção dos argumentos e o estabelecimento de relações comparativas entre operações argumentativas destacam-se no trabalho com textos opinativos.

Em 2006, o Ministério da Educação e Cultura (MEC), em parceria com a Secretaria de Educação Básica (SEB), publicou as Orientações Curriculares para o Ensino Médio. O referencial não sistematiza os conteúdos e/ou as competências e habilidades que devem ser desenvolvidas ao longo do EM, mas enfatiza a 
necessidade de cada escola decidir, por meio de seu projeto político-pedagógico, quais conteúdos específicos devem ser trabalhados e em que momento do ano letivo isso ocorre. Partindo da concepção de língua e linguagem como produto da interação social, indica o trabalho com diferentes agrupamentos de textos que representem os contextos locais (BRASIL, 2006, p. 23-26).

$\mathrm{Na}$ seção destinada aos conhecimentos de língua portuguesa, o documento propõe eixos organizadores das ações de ensino e aprendizagem no EM, dentre elas, atividades de análise das práticas de língua e linguagem em que é possível identificar conteúdos relacionados à escrita argumentativa na descrição das estratégias textualizadoras. As atividades orientam para o trabalho com elementos de articulação das sequências do texto relacionados à construção da argumentação e para o estudo dos modos de organização da composição textual, dos quais faz parte o tipo textual argumentativo (BRASIL, 2006, p. 38-39).

Nos referenciais curriculares nacionais, a argumentação é vista como uma competência a ser desenvolvida. Em termos linguísticos, a argumentação é tratada como uma tipologia textual, um modo de organização de sequências textuais com determinadas características linguísticas reunidas em torno de elementos lexicais e sintáticos e relações lógicas e temporais (MARCUSCHI, 2002, p. 22-23).

\section{A argumentação no Currículo de Língua Portuguesa}

O ensino de argumentação no Currículo de Língua Portuguesa $(C L P)$ tem início na $1^{\underline{a}}$ série do EM, sendo intensificado nas duas séries seguintes, por meio do desenvolvimento de habilidades relacionadas a atividades de leitura e escrita que abordam a tipologia argumentativa (SÃO PAULO, 2010, p. 84-104).

$\mathrm{Na} 1^{1}$ série do EM, a proposta está direcionada para o desenvolvimento de habilidades de leitura e escrita de textos expositivos. Nessa etapa inicial do EM, é explorada a primeira habilidade relacionada ao domínio da leitura e escrita de textos argumentativos: "posicionar-se criticamente diante do texto do outro, defendendo ponto de vista coerente a partir de argumentos" (SÃO PAULO, 2010, p. 84). 
$\mathrm{Na} 2^{\text {a }}$ série, prevê-se o desenvolvimento de doze habilidades ligadas ao domínio da tipologia argumentativa, conforme visto a seguir:

1. Sintetizar opiniões.

2. Distinguir enunciados objetivos e enunciados subjetivos.

3. Reconhecer, em textos, os procedimentos de convencimento, utilizados pelo enunciador.

4. Distinguir notícia de artigo de opinião.

5. Relacionar, em artigos de opinião e anúncios publicitários, opiniões, temas, assuntos, recursos linguísticos, identificando o diálogo entre as ideias e o embate dos interesses existentes na sociedade.

6 . Estabelecer relações lógico-discursivas, analisando o valor argumentativo dos conectivos.

7. Formular opinião sobre determinado fato artístico, científico ou social, defendendo-a por meio de argumentação lógica.

8. Estabelecer relação entre a tese e os argumentos apresentados para defendê-la ou refutá-la.

9. Inferir tese, tema ou assunto principal nos gêneros textuais: artigo de opinião, romance, conto fantástico e poema.

10. Confrontar um texto produzido antes do século XX com outros textos, opiniões e informações, posicionando-se criticamente, levando em conta os diferentes modos de ver o mundo presente.

11. Elaborar estratégias de produção de textos expositivos e argumentativos.

12. Concatenar ideias na estruturação de um texto argumentativo.

(SÃO PAULO, 2012, p. 88; 90-91; 94)

Cinco habilidades são desenvolvidas no $3^{\text {a }}$ série:

1. Identificar a tese e ideias-chave em um texto argumentativo.

2. Projetar dissertações escolares.

3. Relacionar criticamente, na produção de um texto de acesso ao Ensino Superior, informações das diferentes áreas do saber: Filosofia, Economia, Sociologia, Literatura, Arte, entre outras.

4. Posicionar-se criticamente diante da realidade fazendo interagir conceitos, valores ideológicos e elementos linguísticos

5. Analisar as intenções enunciativas dos textos literários na escolha dos temas, das estruturas e dos estilos, como procedimentos argumentativos.

(SÃO PAULO, 2012, p. 98; 100; 102; 104)

A realização efetiva do texto argumentativo somente ocorre na reapresentação das habilidades relacionadas ao domínio da escrita argumentativa no âmbito linguístico-discursivo, o que significa afirmar a necessidade da precisão quanto aos conteúdos de língua portuguesa necessários ao desenvolvimento das habilidades esperadas e da fundamentação teórica que embasa o ensino dos conteúdos definidos. 
Do ponto de vista linguístico-discursivo, o texto argumentativo pressupõe a existência de uma estrutura argumentativa que apresenta, segundo Vilela e Koch (2001, p. 547), seis elementos:

- relação entre os argumentos e a conclusão;

- presença do verbo ser ou equivalente na construção da tese;

- uso de verbos que explicitam a relação de causa/efeito, como causar, originar, ocasionar, etc. e de verbos de elocução, tais como afirmar, declarar, assegurar, etc.;

- uso dos verbos no presente, como tempo de valor universal;

- presença de frases de afirmação, consideradas mais adequadas à argumentação;

- uso de marcadores específicos de coesão e coerência para a ordenação ou conexão dos argumentos, como em primeiro lugar, em segundo lugar, etc. e já que, de modo que, em conclusão, assim, etc.

No CLP (SÃO PAULO, 2010, p. 88; 98), há a indicação expressa da abordagem de apenas dois dos seis elementos mencionados acima: uso de conectores na construção linguística da textualidade, conteúdo indicado no ensino do artigo de opinião (1ํ bimestre, $2^{\circ}$ EM) e estrutura sintática e construção da tese, abordada no ensino da dissertação escolar (2을 bimestre, $3^{\circ}$ EM).

A fundamentação teórica oferecida ao professor é escassa. Nenhuma das 27 obras listadas como referência no CLP aborda os estudos de argumentação, ou apresenta a indicação de uma obra de gramática da língua portuguesa. Apenas quatro títulos dos 48 apresentados como recursos de aprofundamento no material do professor estão diretamente ligados à aprendizagem do texto argumentativo. Dentre esses, um é indicado em um volume da $2^{\mathrm{a}}$ série (Sequência didática: artigo de opinião, de Jacqueline $P$. Barbosa) e três em dois volumes da $3^{\text {a }}$ série ( $O$ texto argumentativo, Linguagem e persuasão, ambos de Adilson Citelli, e Tratado da argumentação: a nova retórica, de Chaïm Perelman e Lucie Olbrecht-Tyteca).

Espera-se que o trabalho do professor de português auxilie na constituição de um sujeito leitor e escritor consciente de seu papel ativo na interação social, em especial, no que se refere à tomada de posição e criticidade. Entretanto, poucas ferramentas da área específica de Língua Portuguesa são dadas para que esse processo se realize. As prescrições do CLP, no que se refere aos conteúdos 
referentes ao ensino do texto argumentativo, concentram-se em aspectos atitudinais e procedimentais, indicando como o aluno deve agir ao final do processo. Aspectos conceituais, relacionados ao eixo linguístico-discursivo, não são aprofundados.

\section{A argumentação no SARESP}

A ênfase no desenvolvimento de habilidades de leitura e escrita de textos argumentativos vincula-se à exigência apresentada nas avaliações do SARESP. Desde 2008, a produção de texto que integra a avaliação exige dos alunos concluintes do EF II e do EM a escrita de um artigo de opinião a partir da leitura de uma coletânea de excertos que problematizam um determinado tema. A exigência pela redação de um artigo de opinião nas séries finais das duas etapas de ensino da Educação Básica parece estar relacionada a duas especificidades do ensino do gênero artigo de opinião: a ocorrência no EF II, único texto argumentativo ensinado nessa etapa de ensino e o aumento de habilidades de leitura e escrita que devem ser desenvolvidas na $2^{\text {a }}$ série do EM, quando o gênero é abordado novamente.

A exigência da escrita do artigo de opinião, na avaliação SARESP, acompanha a prescrição do $C L P$ em relação ao ensino desse gênero, presente no EF II e no EM. Entretanto, ainda que a produção do texto argumentativo seja prescrita e exigida na avaliação por meio da escrita do artigo de opinião, os resultados de redação nos SARESP de 2007 (ano anterior à implementação do Programa SPFE) a 2011 (último resultado divulgado pela Secretaria da Educação) indicam que o percentual de alunos que dominam plenamente as habilidades de escrita de textos argumentativos diminuiu:

Tabela 1 - Comparativo de desempenho em redação - 3ํㅡㄹ

\begin{tabular}{lccccc}
\hline \hline \multicolumn{1}{c}{ Redação 30 EM } & $\mathbf{2 0 0 7}$ & $\mathbf{2 0 0 8}$ & $\mathbf{2 0 0 9}$ & $\mathbf{2 0 1 0}$ & $\mathbf{2 0 1 1}$ \\
\hline \hline Abaixo do básico & 18,2 & 12,9 & 11,9 & 18,6 & 17,5 \\
\hline \hline Básico & 28,4 & 27,8 & 25,0 & 30,8 & 55,0 \\
\hline \hline Adequado & 35,6 & 40,4 & 39,3 & 47,1 & 27,4 \\
\hline \hline Avançado & 14,3 & 18,9 & 23,8 & 3,5 & 0,1 \\
\hline \hline
\end{tabular}

Fonte: SÃO PAULO, 2008, p. 27; 2009, p. 28; 2010, p. 35; 2011, p. 68; 2012, p. 5 
Os níveis de desempenho utilizados na aferição dos resultados obtidos na redação são organizados em uma escala indicativa que varia de 0 a 100, descritos a seguir:

Quadro 1 - Descrição dos níveis de desempenho em redação - SARESP

\begin{tabular}{|c||c||}
\hline Níveis de proficiência & \multicolumn{1}{|c|}{ Descrição } \\
\hline $\begin{array}{c}\text { Abaixo do básico } \\
(<50)\end{array}$ & $\begin{array}{l}\text { Os alunos, neste nível, demonstram domínio insuficiente das } \\
\text { competências e habilidades escritoras desejáveis para o } \\
\text { ano/série escolar em que se encontram. }\end{array}$ \\
\hline $\begin{array}{c}\text { Básico } \\
\text { (entre } 50 \text { e } 60)\end{array}$ & $\begin{array}{l}\text { Os alunos, neste nível, demonstram domínio mínimo das } \\
\text { competências e habilidades escritoras, mas possuem as } \\
\text { estruturas necessárias para interagir com a proposta curricular no } \\
\text { ano/série subsequente. }\end{array}$ \\
\hline \hline $\begin{array}{c}\text { Adequado } \\
(\text { entre } 65 \text { e } 90)\end{array}$ & $\begin{array}{l}\text { Os alunos, neste nível, demonstram domínio pleno das } \\
\text { competências e habilidades escritoras desejáveis para o } \\
\text { ano/série escolar em que se encontram. }\end{array}$ \\
\hline \hline $\begin{array}{c}\text { Avançado } \\
\text { (de } 90 \text { a 100) }\end{array}$ & $\begin{array}{l}\text { Os alunos, neste nível, demonstram domínio das competências e } \\
\text { habilidades escritoras acima do requerido para ono/série } \\
\text { escolar em que se encontram. }\end{array}$ \\
\hline
\end{tabular}

Fonte: SÃO PAULO, 2012, p. 6

A comparação dos resultados da avaliação de redação nos anos de 2007 e de 2011 mostra uma pequena diminuição no percentual de alunos com desempenho abaixo do básico: 18,2\% para 17,5\%. O número de alunos com desempenho básico aumentou, consideravelmente, de $28,4 \%$ para $55,0 \%$. No entanto, o grupo de alunos com desempenho adequado e avançado diminuiu de $35,6 \%$ para $27,4 \%$ e de $14,3 \%$ para $0,1 \%$, respectivamente.

Os dados apresentados nas avaliações SARESP (2007 a 2011) mostram que as medidas tomadas, a partir de 2007, para a melhoria da educação paulista levaram mais da metade dos alunos da rede estadual a demonstrar domínio mínimo das habilidades escritoras esperadas para a série cursada.

Nesse contexto, o apostilado de Língua Portuguesa (ALP) assume papel central na relação entre os dados da realidade advindos dos exames de avaliação SARESP e os alunos do EM da rede pública estadual que necessitam de reais conhecimentos para que possam ler e escrever textos argumentativos de maneira satisfatória. 
O apostilado, utilizado de 2008 a 2013, tem um caráter essencial na formação do aluno e do professor, uma vez que se pode considerá-lo como um material importante e disponível, na sala de aula, para o desenvolvimento do conhecimento específico sobre texto argumentativo definido no CLP.

O desafio de superar os baixos resultados do desempenho dos alunos em um sistema de avaliação que exige a produção de textos argumentativos levou à constituição da análise deste objeto.

\subsection{Composição do objeto de análise}

Nesta parte do capítulo, abordamos a composição do apostilado de Língua Portuguesa (ALP) no que se refere a aspectos formais: a elaboração, realizada por uma equipe de professores de português; a apresentação em fascículos denominados volumes, que correspondem aos Cadernos do Professor (CP) e aos Cadernos do Aluno (CA); e a organização em unidades didáticas chamadas Situações de Aprendizagem, presentes nos CPs e CAs.

\subsubsection{Elaboração do apostilado de Língua Portuguesa}

O apostilado de Língua Portuguesa (ALP), objeto da pesquisa desenvolvida, foi elaborado por uma equipe de autores coordenados pela professora $\mathrm{Dr}^{\mathrm{a}}$ Alice Vieira. A equipe foi formada por professores de Língua Portuguesa com doutorado em educação pela Universidade de São Paulo: Dr $^{\mathrm{a}}$ Débora Mallet Pezarim de Angelo, $\mathrm{Dr}^{\mathrm{a}}$ Eliane Aparecida de Aguiar, Dr José Luís Marques López Landeira e Ms. João Henrique Nogueira Mateos.

A produção e a publicação do ALP, assim como de todo o sistema apostilado da rede pública estadual de ensino, ficaram a cargo da área de Gestão de Tecnologias Aplicadas à Educação da Fundação Vanzolini (GTE/FCAV). A entidade tem fornecido esse material para as todas as escolas estaduais nos últimos seis anos. 
2.2.2 Composição do apostilado de Língua Portuguesa

O apostilado é formado pelos Cadernos do Professor (CP) e pelos Cadernos do Aluno (CA). Em 2009, os CPs foram reformulados, sendo essa edição utilizada até o momento. No caso dos $C A s$, não houve alterações desde a primeira publicação, em 2009. Nessa pesquisa, utilizamos as edições de 2009 dos CPs e de 2010 dos CAs.

O ALP é composto por doze fascículos denominados volumes, distribuídos quatro a cada série do EM. A distribuição de cada volume ocorre no início do bimestre equivalente, sendo vedado ao professor modificar a ordem de sua utilização. Nos CPs, a disciplina é nomeada Língua Portuguesa e Literatura, enquanto nos $C A s$, ela é apresentada somente como Língua Portuguesa.

Cada volume do apostilado é composto por quatro a seis Situações de Aprendizagem, isto é, unidades didáticas que apresentam as atividades a serem realizadas. A quantidade de atividades apresentadas em cada Situação de Aprendizagem é variável, com o mínimo de uma atividade (2ํㅡㄹ, Vol. 1, Situação de Aprendizagem 5: "A palavra e o tempo") e o máximo de vinte e duas atividades ( $1^{\circ} \mathrm{EM}$, Vol. 2, Situação de Aprendizagem 4: “Um, dois, três...ação!"). Nas $1^{\text {a }}$ e $2^{\text {a }}$ séries, são apresentadas 18 Situações de Aprendizagem, e na $3^{a}$ série, 16. 
Tabela 2 - Distribuição dos volumes de Língua Portuguesa (EM)

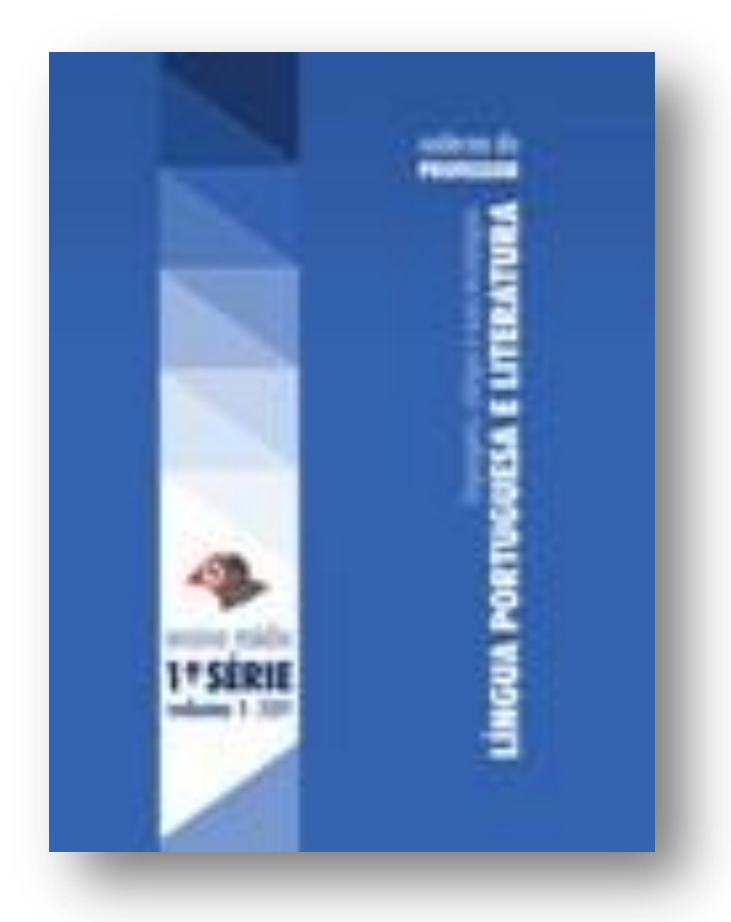

Caderno do Professor $(C P)$

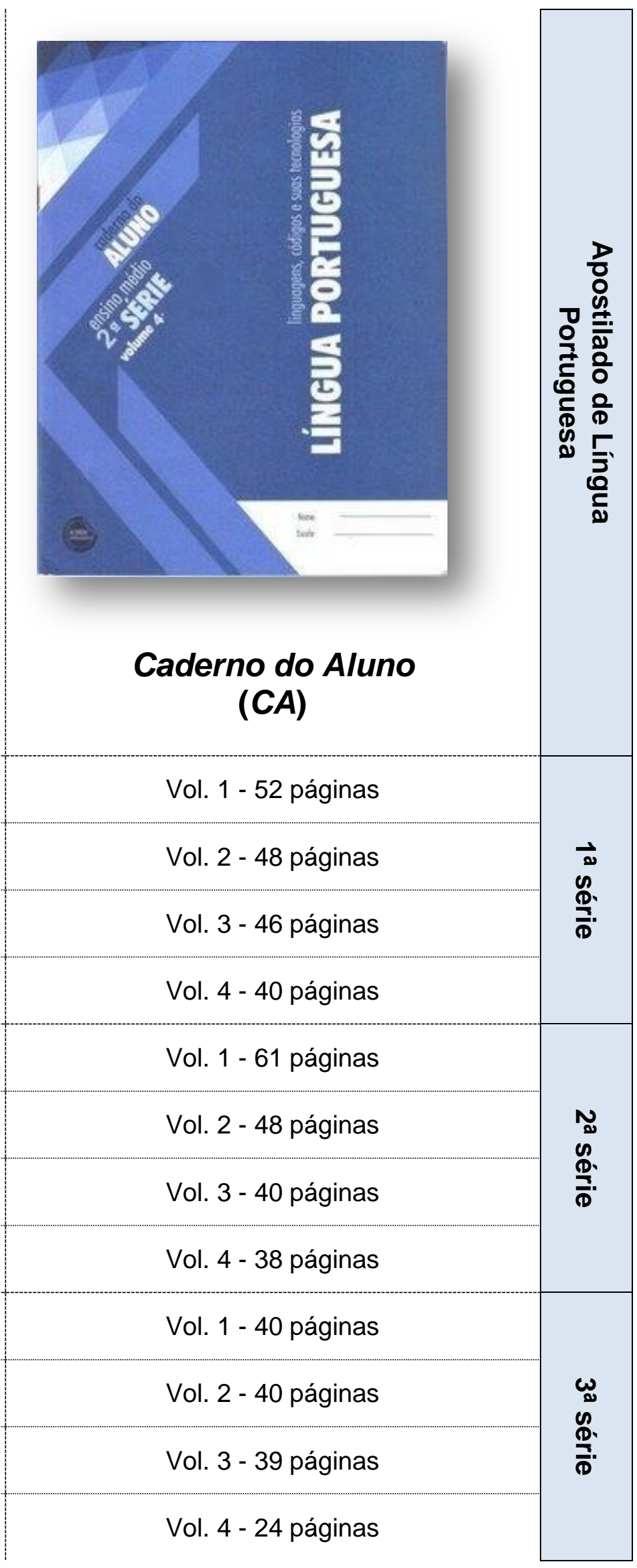




\subsubsection{Organização das Situações de Aprendizagem no Caderno do Aluno}

No Caderno do Aluno $(C A)$, as Situações de Aprendizagem são organizadas em seções didáticas distintas:

a) Em "Para começo de conversa", são realizadas atividades de motivação inicial, nas quais se inicia a abordagem do tema proposto.

b) Em "Discussão oral", são apresentadas questões que devem ser respondidas oralmente, com o objetivo de investigar o conhecimento prévio do aluno a respeito do tema ou refletir sobre o conteúdo recém-abordado.

c) Em "Leitura e Análise de Texto", são apresentados os textos para leitura e compreensão.

d) Em "Lição de casa", são propostas atividades para as tarefas de casa.

e) Em "Para saber mais", são oferecidas indicações de sites, livros e filmes, que aprofundam o conteúdo abordado ou apresentam informações sobre o autor de um texto lido.

f) Em "Você aprendeu?", as atividades propostas têm como objetivo a realização de uma avaliação, na qual o aluno possa mostrar os conhecimentos adquiridos.

Dentre as seções apresentadas, três podem se repetir em uma mesma Situação de Aprendizagem: "Discussão oral", "Leitura e Análise de Texto" e "Lição de casa". As demais ocorrem apenas uma vez em cada sequência didática, e têm posições fixas: "Para começo de conversa" inicia a Situação de Aprendizagem e "Para saber mais" e "Você aprendeu?" finalizam a unidade.

2.2.4 Organização das Situações de Aprendizagem no Caderno do Professor (CP)

As Situações de Aprendizagem são compostas por seis elementos no Caderno do Professor (CP):

1) um quadro inicial, no qual são informados: a) tempo previsto para a realização das atividades propostas na unidade; b) conteúdos e temas abordados; c) 
competências e habilidades desejadas; d) estratégias utilizadas pelo professor na condução das atividades; e) recursos didáticos necessários; f) avaliação de conteúdos assimilados;

2) uma atividade introdutória de motivação inicial, denominada "Sondagem";

3) um roteiro para aplicação da Situação de Aprendizagem com os conteúdos e objetivos específicos da unidade;

4) uma sequência numerada de atividades que constituem a unidade, com a descrição de todas as atividades a serem desenvolvidas com os alunos e os procedimentos a serem tomados pelo professor;

5) um quadro intitulado "Para você, professor!", com respostas de exercícios e explicações sobre o conteúdo abordado;

6) um quadro nomeado "Aprofundando conhecimentos", com citações de obras de referência, relacionadas ao conteúdo abordado na Situação de Aprendizagem.

As Situações de Aprendizagem direcionam o trabalho do professor no que se refere às questões pertinentes ao processo de ensino $-O$ que ensinar? Por quê? Como? Em quanto tempo? - reforçando o caráter prescritivo e metodológico do trabalho do professor.

\subsection{Trabalho prescrito do professor}

Os conteúdos relacionados ao ensino do texto argumentativo, prescritos no $C L P$, são reapresentados nos CPs e CAs, de modo que o desenvolvimento de competências e habilidades exigidas seja transposto para o campo linguísticodiscursivo, constituindo-se como o trabalho prescrito do professor.

Nesta parte do capítulo, apresentamos as etapas do trabalho prescrito do professor. Essas etapas apontam para quatro níveis de abrangência, a partir dos quais delimitamos o objeto de análise: 1) Conteúdos prescritos para o EM no CLP; 2) Reapresentação dos conteúdos prescritos nas Situações de Aprendizagem; 3) Conteúdos de produção escrita; 4) Conteúdos de produção escrita argumentativa. 
De acordo com Souza-e-Silva (2004, p. 84), a prescrição no campo educacional consiste no conjunto de "aspectos institucionais ou normativos, quer formais ou informais, que regem o trabalho do professor em seu dia a dia". O conceito de trabalho prescrito do professor, abordado por pesquisadores da área de Linguagem e Trabalho (BARRICELLI, 2012; ANJOS, 2010; CUNHA, 2008; PORTELA, 2006; LOUSADA, 2006; SOUZA-E-SILVA, 2004), desenvolve-se no âmbito da Ergonomia da Atividade, ciência do trabalho de vertente francesa. Sua origem relaciona-se à Teoria da Ergonomia, surgida na década de 1940 na GrãBretanha, durante a $2^{\mathrm{a}}$ Guerra Mundial, em que pesquisas ergonômicas buscavam a melhor adaptação das máquinas aos combatentes. Na década de 1950, na França, os pesquisadores da Ergonomia passaram a investigar o trabalho humano, delineando o campo de estudo da Ergonomia da Atividade (ANJOS, 2010, p. 21).

O trabalho prescrito do professor é descrito a seguir, observando-se os quatro níveis de abrangência mencionados anteriormente, aos quais se relaciona a escolha das atividades didáticas que constituem o objeto de pesquisa.

1ำ nível: Conteúdos prescritos para o EM no Currículo de Língua Portuguesa

O primeiro nível do trabalho prescrito do professor fundamenta-se na normatização dos conteúdos mínimos para o EM apresentados no CLP. Esses conteúdos são organizados em quatro campos de estudo da língua:

a) Linguagem e sociedade: análise externa da língua e da literatura em sua dimensão social;

b) Leitura e expressão escrita: estudo das características dos gêneros textuais;

c) Funcionamento da língua: análise interna da língua e da literatura;

d) Produção e compreensão oral: produção e escuta de textos orais. ${ }^{6}$

Essa organização evita a divisão da disciplina por frentes de trabalho (literatura, gramática e redação), comuns na condução da Língua Portuguesa no EM. A divisão em campos de estudo só é visível para o professor no CLP, na

\footnotetext{
${ }^{6}$ Fonte: SÃO PAULO, 2010, p.36.
} 
organização dos conteúdos a serem desenvolvidos em cada bimestre de cada série. No $C P$ e no $C A$, não há menção aos campos de estudo, que se inter-relacionam na composição das atividades.

Em seguida, apresentamos os conteúdos prescritos no CLP relacionados aos campos de estudo Linguagem e sociedade e Leitura e expressão escrita, nos quais são apresentados os objetos de ensino referentes ao texto argumentativo. 

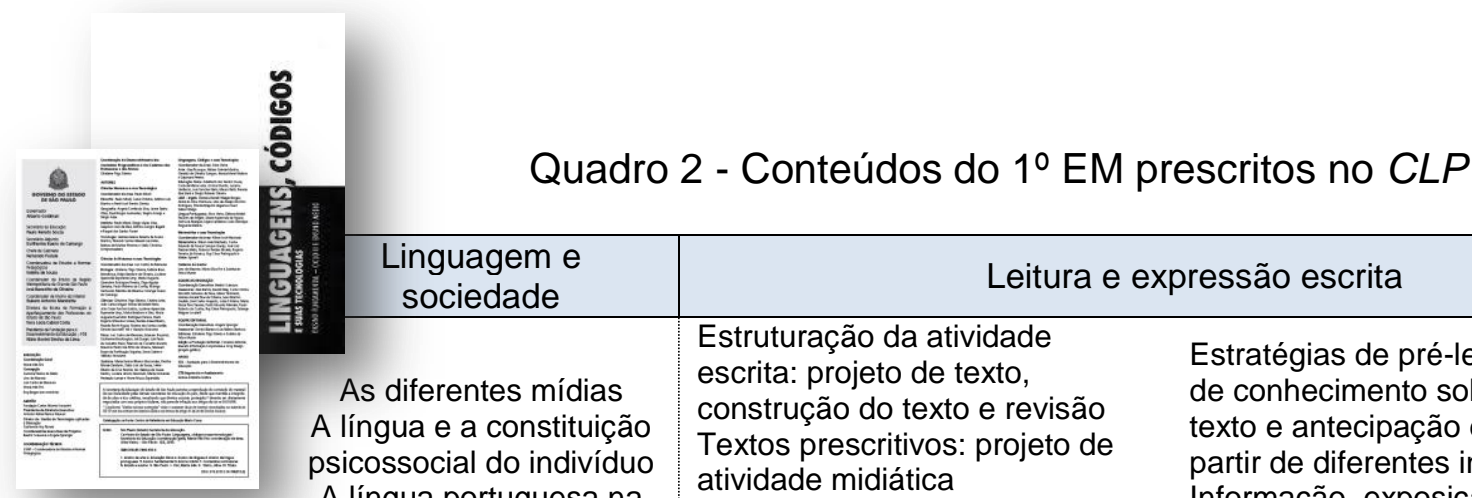

\section{Linguagem e sociedade \\ xpressão escrita}

As diferentes mídias A língua e a constituição psicossocial do indivíduo A língua portuguesa na escola: o gênero textual

no cotidiano escolar

A literatura na sociedade atual

Lusofonia e história da

língua portuguesa

\section{Linguagem $e$ sociedade}

\section{A exposição artística e o} uso da palavra

Comunicação e relações sociais

Discurso e valores pessoais e sociais

Literatura e Arte como instituições sociais Variedades linguísticas: preconceito linguístico

Leitura e expre
Estruturação da atividade
escrita: projeto de texto,
construção do texto e revisão
Textos prescritivos: projeto de
atividade midiática
Texto lírico (leitura): poema
Texto narrativo: conto tradicional
Texto argumentativo: opiniões
pessoais
Texto expositivo: tomada de
notas, resumo de texto
audiovisual, legenda
Relato: notícia

Estratégias de pré-leitura: relações de conhecimento sobre o gênero do texto e antecipação de sentidos a partir de diferentes indícios Informação, exposição de ideias e mídia impressa

Intencionalidade comunicativa

Estratégias de pós-leitura

Organização de informação e utilização das habilidades desenvolvidas em novos contextos de leitura
Estratégias de pré-leitura: conhecimento sobre o gênero do texto e antecipação de sentidos a partir de diferentes indícios

Estruturação da atividade escrita: projeto de texto, construção do texto e revisão Textos prescritivos: projeto de atividade extracurricular Texto teatral / diferenças entre texto teatral e texto espetacular: fábula

\begin{tabular}{|c|c|c|}
\hline $\begin{array}{l}\text { Linguagem e } \\
\text { sociedade }\end{array}$ & \multicolumn{2}{|c|}{ Leitura e expressão escrita } \\
\hline $\begin{array}{c}\text { A literatura como sistema } \\
\text { intersemiótico } \\
\text { O eu e o outro: a } \\
\text { construção do diálogo e } \\
\text { do conhecimento }\end{array}$ & $\begin{array}{l}\text { Estratégias de pré-leitura: } \\
\text { conhecimento sobre o gênero } \\
\text { do texto e antecipação de } \\
\text { sentidos a partir de diferentes } \\
\text { indícios } \\
\text { Estruturação da atividade } \\
\text { escrita: projeto de texto, } \\
\text { construção do texto e revisão } \\
\text { Textos prescritivos: projeto de } \\
\text { texto } \\
\text { Texto argumentativo: estrutura } \\
\text { tipológica } \\
\text { Texto expositivo: folder e } \\
\text { entrevista }\end{array}$ & $\begin{array}{l}\text { Texto lírico: poema e contexto } \\
\text { histórico } \\
\text { Texto narrativo: conto, comédia e } \\
\text { tragédia As entrevistas e a mídia } \\
\text { impressa } \\
\text { Relações entre literatura e outras } \\
\text { expressões da Arte } \\
\text { Intencionalidade comunicativa } \\
\text { Estratégias de pós-leitura } \\
\text { Organização de informação e } \\
\text { utilização das habilidades } \\
\text { desenvolvidas em novos contextos } \\
\text { de leitura }\end{array}$ \\
\hline $\begin{array}{l}\text { Linguagem e } \\
\text { sociedade }\end{array}$ & \multicolumn{2}{|c|}{ Leitura e expressão escrita } \\
\hline $\begin{array}{l}\text { A construção do caráter } \\
\text { dos enunciados } \\
\text { A palavra: profissões e } \\
\text { campo de trabalho } \\
\text { O texto literário e o } \\
\text { tempo }\end{array}$ & $\begin{array}{l}\text { Estratégias de pré-leitura: } \\
\text { conhecimento sobre o gênero } \\
\text { do texto e antecipação de } \\
\text { sentidos a partir de diferentes } \\
\text { indícios } \\
\text { Estruturação da atividade } \\
\text { escrita: projeto de texto, } \\
\text { construção do texto e revisão } \\
\text { Texto narrativo: prosa literária } \\
\text { (comparação entre diferentes } \\
\text { gêneros de ficção), cordel, } \\
\text { epopeia }\end{array}$ & $\begin{array}{l}\text { Texto argumentativo: ethos e } \\
\text { produção escrita, a opinião crítica e } \\
\text { a mídia impressa } \\
\text { Estratégias de pós-leitura } \\
\text { Organização de informação e } \\
\text { utilização das habilidades } \\
\text { desenvolvidas em novos contextos } \\
\text { de leitura } \\
\text { Intencionalidade comunicativa }\end{array}$ \\
\hline
\end{tabular}

Fonte: SÃO PAULO, 2010, p. 76-77; 79-80; 82-83; 85

Texto narrativo: crônica

Texto lírico: poema

Texto expositivo: folheto, resumo O texto literário e a mídia impressa Intencionalidade comunicativa Estratégias de pós-leitura Organização de informação e utilização das habilidades desenvolvidas em novos contextos de leitura 


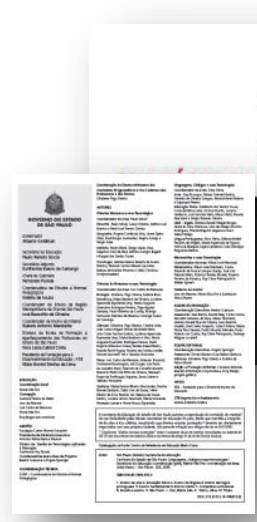

Quadro 3 - Conteúdos do $2^{\circ}$ EM prescritos no CLP

Linguagem e sociedade

A linguagem e a crítica de valores sociais

A palavra e o tempo:

texto e contexto social

Como fazer para gostar de ler literatura?

O estatuto do escritor na sociedade

Os sistemas de arte e de entretenimento

O século XIX e a poesia

\author{
Leitura e expressão escrita
}

Estratégias de pré-leitura: relações de conhecimento sobre o gênero do texto e antecipação de sentidos a partir de diferentes indícios Estruturação da atividade escrita: projeto de texto, construção do texto e revisão

Texto narrativo: textos em prosa (romance), comédia
Texto prescritivo: projeto de texto Texto lírico: poema (visão temática) anúncio publicitário

Argumentação, expressão de opiniões e mídia impressa

Intencionalidade comunicativa

Estratégias de pós-leitura das habilidades desenvolvidas em novos contextos de leitura
Texto argumentativo: artigo de opinião,

Organização de informação e utilização
Literatura e seu estatuto $\mathrm{O}$ escritor no contexto social-político-econômico do século XIX

$O$ indivíduo e os pontos de vista e valores sociais Romantismo e Ultrarromantismo

Valores e atitudes

Linguagem e
sociedade
culturais no texto literário

Estratégias de pré-leitura: relações de conhecimento sobre o gênero do texto e antecipação de sentidos a partir de diferentes indícios Estruturação da atividade escrita: projeto de texto, construção do texto e revisão

Texto prescritivo: projeto de texto

Texto narrativo: romance, conto fantástico

\begin{tabular}{|c|c|c|c|}
\hline $\begin{array}{c}\text { Linguagem e } \\
\text { sociedade }\end{array}$ & \multicolumn{2}{|c|}{ Leitura e expressão escrita } & \\
\hline $\begin{array}{l}\text { Ética, sexualidade e } \\
\text { linguagem } \\
\text { Literatura e seu estatuto } \\
\text { O escritor no contexto } \\
\text { social-político-econômico } \\
\text { do século XIX } \\
\text { As propostas pós- } \\
\text { românticas e a literatura } \\
\text { realista e naturalista }\end{array}$ & $\begin{array}{l}\text { Estratégias de pré-leitura: } \\
\text { relações de conhecimento sobre } \\
\text { o gênero do texto e antecipação } \\
\text { de sentidos a partir de } \\
\text { diferentes indícios } \\
\text { Estruturação da atividade } \\
\text { escrita: projeto de texto, } \\
\text { construção do texto e revisão } \\
\text { Texto prescritivo : projeto de } \\
\text { texto } \\
\text { Texto expositivo: reportagem e } \\
\text { correspondência }\end{array}$ & $\begin{array}{l}\text { Texto argumentativo: estrutura } \\
\text { tipológica } \\
\text { Texto narrativo: o símbolo e a moral } \\
\text { Texto lírico: o símbolo e a moral, } \\
\text { poema } \\
\text { Relato: perfil biográfico } \\
\text { Intencionalidade comunicativa } \\
\text { Estratégias de pós-leitura } \\
\text { Organização de informação e } \\
\text { utilização das habilidades } \\
\text { desenvolvidas em novos contextos } \\
\text { de leitura }\end{array}$ & $\begin{array}{l}\omega \\
10 \\
\frac{\sigma}{\overline{3}} \\
\frac{\mathbb{D}}{0} \\
\frac{0}{1}\end{array}$ \\
\hline $\begin{array}{l}\text { Linguagem e } \\
\text { sociedade }\end{array}$ & \multicolumn{2}{|c|}{ Leitura e expressão escrita } & \\
\hline $\begin{array}{l}\text { Literatura e realidade } \\
\text { social } \\
\text { Comunicação, sociedade } \\
\text { e poder } \\
\text { Ruptura e diálogo entre } \\
\text { linguagem e tradição }\end{array}$ & $\begin{array}{l}\text { Estratégias de pré-leitura: } \\
\text { relações de conhecimento } \\
\text { sobre o gênero do texto e } \\
\text { antecipação de sentidos a } \\
\text { partir de diferentes indícios } \\
\text { Estruturação da atividade } \\
\text { escrita: projeto de texto, } \\
\text { construção do texto e revisão } \\
\text { Texto literário: conto (ruptura } \\
\text { com a tradição), poema } \\
\text { (subjetividade e objetividade) } \\
\text { Texto expositivo: entrevista }\end{array}$ & $\begin{array}{l}\text { Relato: reportagem } \\
\text { Texto informativo: folder ou prospecto } \\
\text { A expressão de opiniões pela } \\
\text { instituição jornalística } \\
\text { Intencionalidade comunicativa } \\
\text { Estratégias de pós-leitura } \\
\text { Organização de informação e } \\
\text { utilização das habilidades } \\
\text { desenvolvidas em novos contextos de } \\
\text { leitura }\end{array}$ & 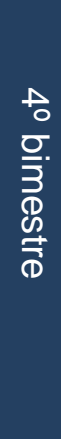 \\
\hline
\end{tabular}

Texto lírico: poema (a denúncia social) Texto argumentativo: artigo de opinião Argumentação, expressão de opiniões e mídia impressa Intencionalidade comunicativa Estratégias de pós-leitura Organização de informação e utilização das habilidades desenvolvidas em novos contextos de leitura

Fonte: SÃO PAULO, 2010, p. 87; 89; 92-93; 95 


\section{Quadro 4 - Conteúdos do $3^{\circ}$ EM prescritos no CLP}

Linguagem e sociedade

\section{Leitura e expressão escrita}

Estratégias de pré-leitura: relações de conhecimento

A literatura e a construção da modernidade e do moderno

Linguagem e desenvolvimento do olhar crítico sobre o gênero do texto e antecipação de sentidos a partir de diferentes indícios Estruturação da atividade escrita: projeto de texto, construção do texto $e$ revisão

Texto prescritivo: projeto de texto

Texto narrativo: a narrativa moderna, cartum ou $\mathrm{HQ}$

Texto lírico: a lírica moderna

Texto argumentativo: resenha crítica Argumentação, crítica e mídia impressa Intencionalidade comunicativa Estratégias de pós-leitura Organização de informação e utilização das habilidades desenvolvidas em novos contextos de leitura

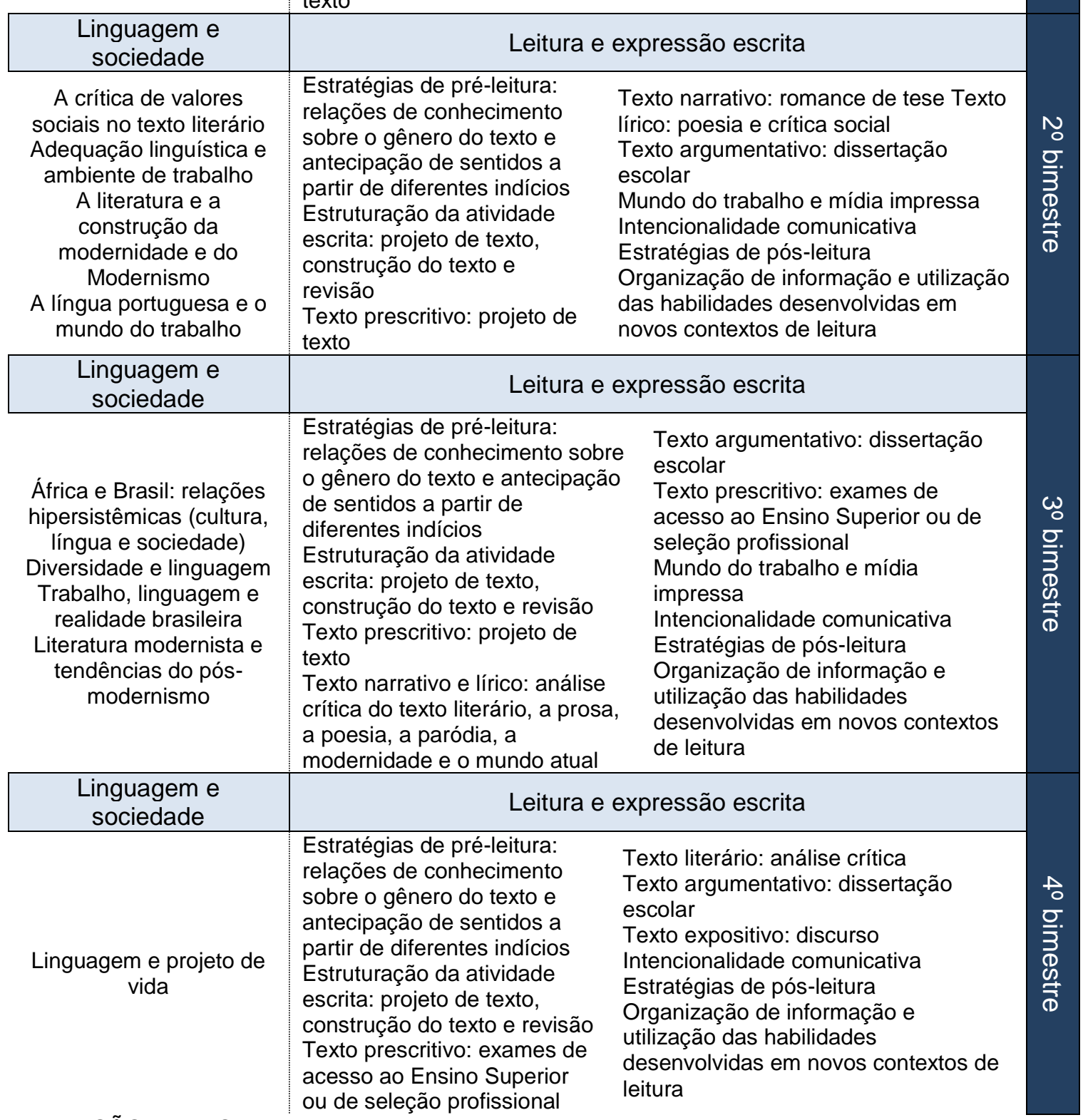

Fonte: SÃO PAULO, 2010, p. 97; 99; 101; 103 
2o nível: Reapresentação dos conteúdos nas Situações de Aprendizagem

O segundo nível do trabalho prescrito, formado pela reapresentação dos conteúdos nas Situações de Aprendizagem presentes no $C P$, confirma a prescrição constitutiva do CLP ao articular elementos do campo pedagógico ao linguístico. O documento oficial e o material dirigido ao professor dialogam fortemente, na medida em que a gênese de ambos ocorre na mesma época, conforme mencionamos no capítulo 1 , dando início à normatização do currículo estadual.

No $C P$, o diálogo com o professor estabelece-se por meio de verbos no modo imperativo. Formas verbais como "explique", "faça", "selecione", "considere", "não deixe de perguntar" etc. são utilizadas de maneira significativa. Nas demais ocorrências, verificamos modalizações de valor condicional como "se julgar conveniente,...", ou expressões com o modo subjuntivo "é importante que peça aos alunos...". A preferência pelo uso do modo imperativo marca linguisticamente o caráter prescritivo do $C P$.

Em seguida, apresentamos as Situações de Aprendizagem que compõem os CPs e os conteúdos correspondentes. 
Quadro 5 - Reapresentação dos conteúdos de 1ํㅡ EM no $C P$

\begin{tabular}{l|l|l|}
\hline \hline & \multicolumn{2}{l|}{ 1. Comunicação - palavras no mural } \\
\hline & 2. Lusofonia - sim, nós falamos português! \\
\hline 3. Você está na mídia?
\end{tabular}

O mural escolar; verbetes de dicionário ou de enciclopédia; notícia informativa; tomada de notas

Lusofonia (conceito); notícia jornalística informativa; título de notícia jornalística

Identificação de palavras-chave em um texto; legendas; sinônimos e antônimos

Breve histórico da Língua Portuguesa; conceito de ideias-chave em textos; pesquisa biográfica; diálogo intersemiótico com poesia

Diferença entre poema e poesia; versão crítica do estudo da gramática; uso estilístico, semântico e literário dos verbos, adjetivos e substantivos

Conto tradicional; teoria da narrativa

A exposição artística e o uso da palavra; texto expositivo; valor estilístico dos verbos

Gênero textual - folheto de divulgação; projeto de folheto de divulgação; foco

Literatura e arte; crônica

Conceito de gênero; a fábula; texto teatral; diferenças entre texto teatral e texto espetacular; verbo: aspectos estilísticos; polissemia

Características do gênero entrevista; valor estilístico do verbo: a construção do futuro; concatenação de ideias na construção do texto

Relações entre verbo e narrativa; o conto como realidade literária intersemiótica; texto teatral - comédia e tragédia: diferenças

Poesia como sistema intersemiótico; produção e interpretação de texto artístico; expressão artística moderna intersemiótica: a instalação; elaboração de folder

\section{Elaboração de resenha}

Características de estilo de época; construção da imagem do autor - ethos - e estilo; os principais estilos de época da literatura em língua portuguesa

Interação entre estilo de época, estilo de autor e obra literária; a crítica social da literatura: Os lusíadas, de Luís Vaz de Camões; valor estilístico dos artigos e dos numerais

Aspectos estruturais do texto literário e a construção de sentido; a crítica social na literatura: a literatura de cordel; valor estilístico dos pronomes

Introdução à construção da análise crítica com base em textos literários produzidos pelos alunos; a escrita, o aprendizado de língua portuguesa e o mercado de trabalho

Fonte: SÃO PAULO, 2009, 1ª série, Vol.1, p.11; 19; 24; 30; 37; 43; Vol.2, p.10;20; 26; 37; Vol.3, p.10; 19; 26; 39; Vol.4, p.10; $19 ; 26 ; 35$ 
Quadro 6 - Reapresentação dos conteúdos de 2 EM no $C P$

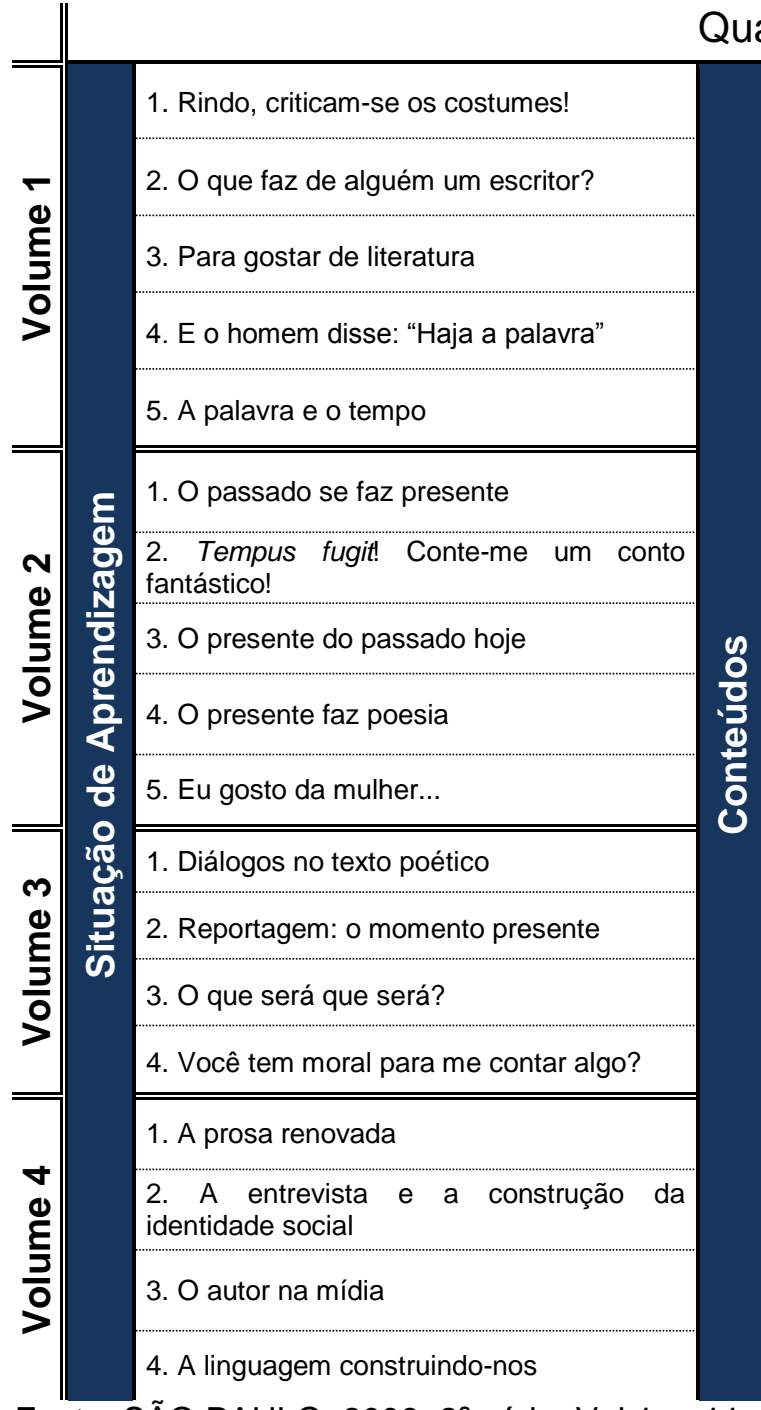

Comédia de costumes; período simples e composto; texto e contexto social

Conceito e definição de argumentação; texto argumentativo: artigo de opinião; conectores: conjunções

Os sistemas de arte e de distração; como fazer para gostar de literatura?; texto e contexto social; o romance

Valor expressivo do período simples; coordenação e subordinação; sintaxe e argumentação; anúncio publicitário; slogan

Poemas: visão temática; o século XIX e a poesia; antologia

A questão de vestibular de literatura - interação entre elementos literários e linguísticos; a obra de Álvares de Azevedo: época, contexto e estilo; a metáfora

Tempus fugit e a crise na identidade social do poeta; o conto fantástico gótico; Romantismo, Ultrarromantismo e Álvares de Azevedo

Artigo de opinião - concatenação de ideias e uso de conectores; a poesia de denúncia social - Castro Alves

O gênero entrevista - tecido linguístico, concatenação de ideias e progressão textual; a poesia contemporânea e o estatuto social do poeta; produção de artigo de opinião

Análise estilística - advérbio e metonímia; valores sociais e culturais no texto; estrutura do projeto de texto

Movimentos poéticos pós-românticos; considerações sobre o estatuto do poeta na sociedade; intertextualidade, dialogismo e poesia

Reportagem; "sequencialização" de parágrafos e elementos de conexão; o estatuto social do poeta

Correspondência pessoal; a sexualidade e a linguagem; poesia: ruptura e diálogo com a tradição; análise estilística: preposição

A parábola, a fábula e a alegoria: o símbolo e a moral

O conto literário e a modernidade: ruptura e tradição; a construção das relações sociais e do eu

Linguagem, interação e entrevista televisiva; a entrevista televisiva e a construção da identidade social; análise estilística: coordenação e subordinação

Análise da influência no processo de escrita literária; a entrevista televisiva e a construção da identidade social; a reportagem com base na entrevista

A poesia: a subjetividade e a objetividade; folder ou prospecto; autoavaliação e construção do conhecimento linguístico

Fonte: SÃO PAULO, 2009, 2ª série, Vol.1, p.11; 19; 29; 38; 45; Vol.2, p.10; 18; 30; 39; 44; Vol.3, p.9; 18; 25; 33; Vol.4, p.10; 19; 26; 30 
Quadro 7 - Reapresentação dos conteúdos de 3ํㅡㄹ no $C P$

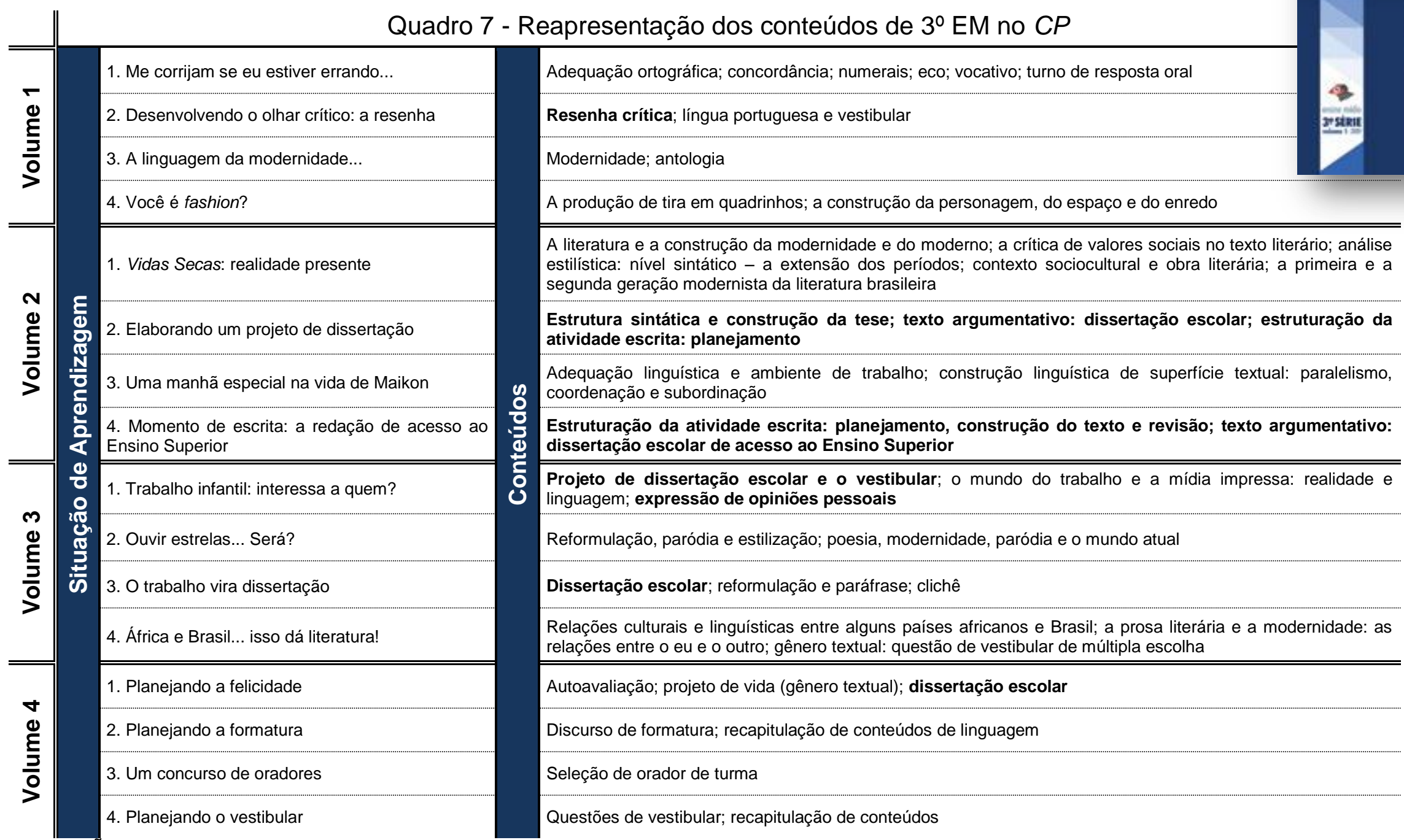

Fonte: SÂO PAULO, 2009, 3로 série, Vol.1, p.11; 15; 20; 25; Vol.2, p.10; 19; 25; 31; Vol.3, p.10; 14; 22; 24; Vol.4, p.10; 17; 25; 27 
3o nível: Conteúdos de produção escrita

A partir dos conteúdos apresentados no CLP e reapresentados nas Situações de Aprendizagem dos CPs, organizamos o terceiro nível do trabalho prescrito do professor, que diz respeito aos conteúdos de produção escrita prescritos pelo documento oficial.

De acordo com o CLP, a escrita é abordada em conjunto com a leitura, consideradas no material como indissociáveis (SÃO PAULO, 2010, p. 14-15). Conforme mencionado na primeira parte deste capítulo, o desenvolvimento de habilidades leitoras e escritoras ocorre em situações que priorizam a utilização de uma determinada tipologia de texto, a partir da qual são selecionados os gêneros trabalhados em cada série.

A abordagem das tipologias e gêneros subsequentes pode apresentar três tipos de atividades: de leitura, de escrita ou de leitura e escrita, conforme mostram os quadros 2, 3 e 4, apresentados anteriormente. Na composição do terceiro nível do trabalho prescrito do professor, recortamos a abordagem de tipologias e gêneros que enfocam o desenvolvimento da escrita ou da leitura e da escrita em conjunto, conforme mostra o quadro a seguir. 
Quadro 8 - Conteúdos de produção escrita

\begin{tabular}{|c|c|c|c|c|c|c|}
\hline \multicolumn{2}{|c|}{$10 \mathrm{EM}$} & \multicolumn{2}{|c|}{ 2 EM } & \multicolumn{2}{|c|}{ 3으 EM } & \multirow{5}{*}{ 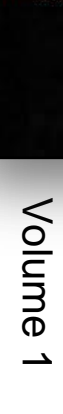 } \\
\hline Tipologia & Gênero & Tipologia & Gênero & Tipologia & Gênero & \\
\hline \multirow[t]{2}{*}{ Texto expositivo } & \multirow{2}{*}{$\begin{array}{c}\text { Tomada de notas } \\
\text { Resumo de texto } \\
\text { audiovisual } \\
\text { Legenda }\end{array}$} & \multirow{3}{*}{$\begin{array}{c}\text { Texto } \\
\text { argumentativo }\end{array}$} & \multirow{3}{*}{$\begin{array}{c}\text { Artigo de opinião } \\
\text { Anúncio } \\
\text { publicitário }\end{array}$} & $\begin{array}{c}\text { Texto } \\
\text { argumentativo }\end{array}$ & Resenha crítica & \\
\hline & & & & \multirow{2}{*}{ Texto narrativo } & \multirow{2}{*}{$\begin{array}{c}\text { Tira em } \\
\text { quadrinhos }\end{array}$} & \\
\hline Relato & Notícia & & & & & \\
\hline Texto prescritivo & Projeto de texto & Texto narrativo & $\begin{array}{c}\text { Romance } \\
\text { Conto fantástico }\end{array}$ & \multirow{2}{*}{$\begin{array}{c}\text { Texto } \\
\text { argumentativo }\end{array}$} & \multirow{2}{*}{$\begin{array}{c}\text { Dissertação } \\
\text { escolar }\end{array}$} & \multirow{2}{*}{$\begin{array}{l}\frac{\delta}{C} \\
\frac{\text { C }}{3} \\
\text { D } \\
N\end{array}$} \\
\hline Texto expositivo & $\begin{array}{l}\text { Folheto de } \\
\text { divulgação }\end{array}$ & $\begin{array}{c}\text { Texto } \\
\text { argumentativo }\end{array}$ & Artigo de opinião & & & \\
\hline Texto expositivo & $\begin{array}{c}\text { Folder } \\
\text { Entrevista }\end{array}$ & Texto expositivo & Reportagem & $\begin{array}{c}\text { Texto } \\
\text { argumentativo }\end{array}$ & $\begin{array}{c}\text { Dissertação } \\
\text { escolar }\end{array}$ & 을 \\
\hline $\begin{array}{c}\text { Texto } \\
\text { argumentativo }\end{array}$ & Resenha & Texto narrativo & $\begin{array}{c}\text { Parábola, fábula, } \\
\text { apólogo }\end{array}$ & $\begin{array}{c}\text { Texto } \\
\text { narrativo/lírico }\end{array}$ & $\begin{array}{l}\text { Paródia e } \\
\text { estilização }\end{array}$ & $\begin{array}{l}\overline{3} \\
\bar{D} \\
\omega\end{array}$ \\
\hline \multirow{3}{*}{$\begin{array}{c}\text { Texto } \\
\text { argumentativo }\end{array}$} & \multirow{3}{*}{ Resenha } & Texto expositivo & Entrevista & \multirow{2}{*}{$\begin{array}{c}\text { Texto } \\
\text { argumentativo }\end{array}$} & \multirow{2}{*}{$\begin{array}{c}\text { Dissertação } \\
\text { escolar }\end{array}$} & \multirow{3}{*}{$\begin{array}{l}\frac{\delta}{c} \\
\frac{1}{3} \\
\text { (1) } \\
+\infty\end{array}$} \\
\hline & & Relato & Reportagem & & & \\
\hline & & Texto informativo & $\begin{array}{l}\text { Folder ou } \\
\text { prospecto }\end{array}$ & Texto expositivo & Discurso & \\
\hline
\end{tabular}

Fonte: SÃO PAULO, 2010, p. 76-104 
4ํ nível: Conteúdos de produção escrita argumentativa

O quarto nível de trabalho prescrito organiza-se em torno dos conteúdos de produção escrita argumentativa. Nessa etapa, tomamos como base as Situações de Aprendizagem apresentadas nos $C A$ s, elaborado um ano depois dos $C P \mathrm{~s}$, para que o estabelecimento de relações entre a prescrição dirigida ao professor, concomitante à normatização do currículo estadual, e a proposta de atividades dirigida ao aluno se realize.

A abordagem da produção escrita argumentativa começa na $1^{\text {a }}$ série e perdura até a $3^{a}$ série, com o ensino de quatro gêneros com características da tipologia argumentativa: resenha, artigo de opinião, anúncio publicitário e dissertação escolar. Considerando a recorrência desses gêneros ao longo das três séries e o predomínio da linguagem verbal em sua constituição, optamos por não incluir o gênero anúncio publicitário, restringindo o objeto de análise ao conjunto formado pelos gêneros resenha, artigo de opinião e dissertação escolar.

O gênero resenha é abordado pela primeira vez na $1^{\underline{a}}$ série, na Situação de Aprendizagem "As vozes do outro e a nossa na resenha" (Vol. 3, $1^{\circ} \mathrm{EM}$ ) e retomado na mesma série, na Situação de Aprendizagem "A análise crítica em sala de aula" (Vol. 4, $1^{\circ} \mathrm{EM}$ ). Ao longo da $2^{\mathrm{a}}$ série, o gênero não é trabalhado, e somente na $3^{\mathrm{a}}$ série, na Situação de Aprendizagem "Desenvolvendo o olhar crítico: a resenha" (Vol. 1, 3ํㅡㄹ) há menção à resenha sob a forma de uma proposta de produção escrita.

O ensino do gênero artigo de opinião ocorre na $2^{\text {a }}$ série, nas Situações de Aprendizagem "O que faz de alguém um escritor?" (Vol. 1, $2^{\text {a }}$ série $\left.E M\right)$ e "O presente do passado hoje" (Vol. 2, $2^{\mathrm{a}}$ série EM).

A dissertação escolar aparece na $3^{\underline{a}}$ série, nas Situações de Aprendizagem "Elaborando um projeto de dissertação" (Vol. 2, 3a série EM), "Momento de escrita: a redação de acesso ao ensino superior" (Vol. 2, $3^{\text {a }}$ série EM), "Trabalho infantil: interessa a quem?" (Vol. 3, 3 ${ }^{\text {a }}$ série EM), "O trabalho vira dissertação" (Vol. 3, $3^{\text {a }}$ série EM) e "Planejando a felicidade" (Vol. 4, $3^{\mathrm{a}}$ série EM).

Para a constituição do objeto de estudo, escolhemos as atividades didáticas que tiveram como objetivo principal ensinar a escrever textos dos gêneros 
mencionados, propondo atividades de leitura e produção escrita que contribuíssem para esse fim. Desse modo, do grupo de dez Situações de Aprendizagem mencionadas acima, selecionamos quatro, conforme mostra o quadro a seguir:

Quadro 9 - Composição do objeto de pesquisa

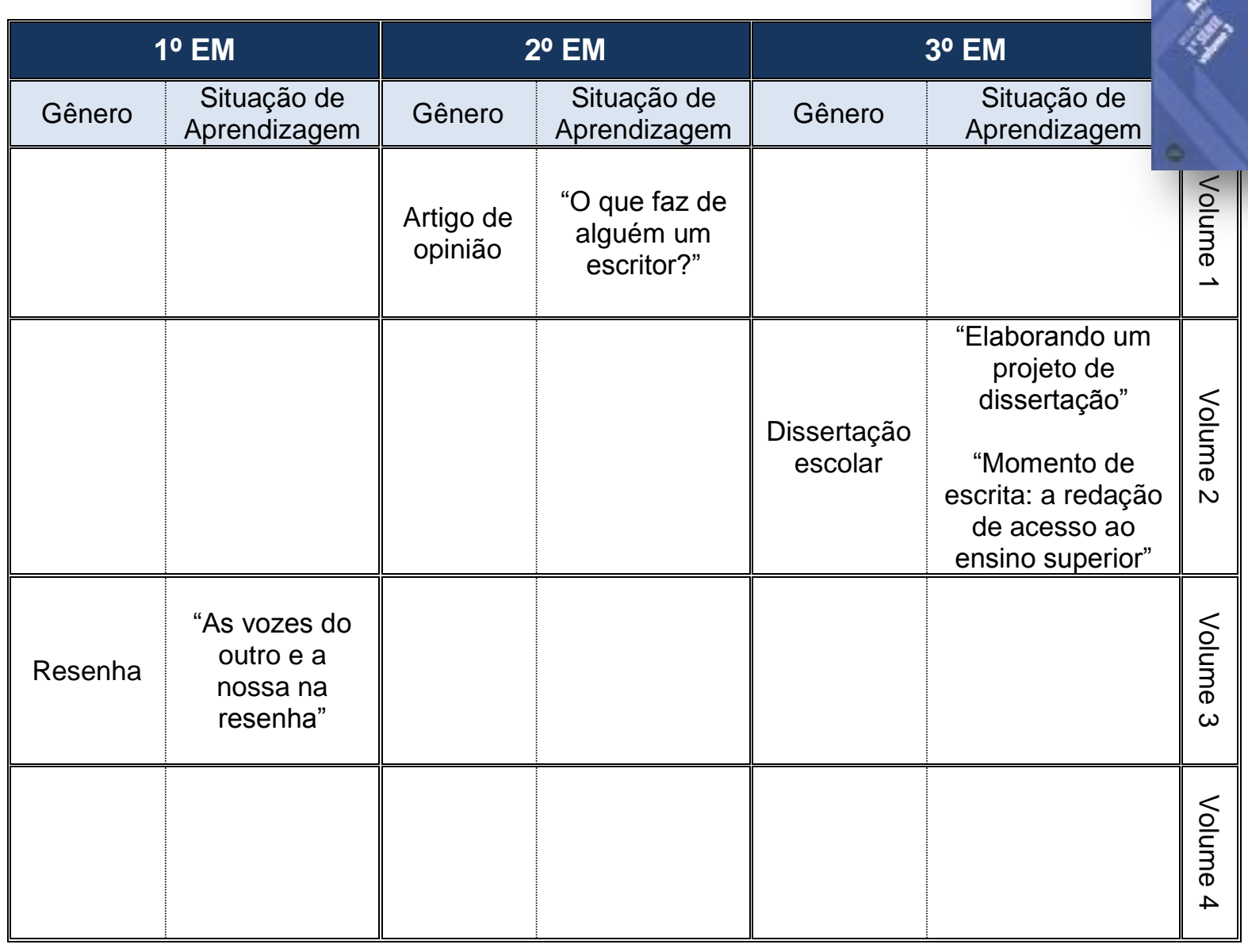

O percurso metodológico para o ensino do texto argumentativo é semelhante nas Situações de Aprendizagem analisadas. Inicia-se a abordagem do tema proposto por uma atividade de motivação inicial, seguida pela leitura e compreensão de um texto integral ou de fragmentos de textos, em geral, pertencentes ao gênero abordado. Apresenta-se o conteúdo teórico pertinente ao assunto tratado com textos didáticos elaborados pelos autores do material, sob a forma de exercícios, que podem ser realizados em aula ou como tarefa de casa. A Situação de Aprendizagem propõe, na etapa final das atividades, a escrita de um texto no gênero abordado. $O$ esquema seguinte permite a visualização da sequência das etapas didáticas: 


\section{Situação de Aprendizagem}
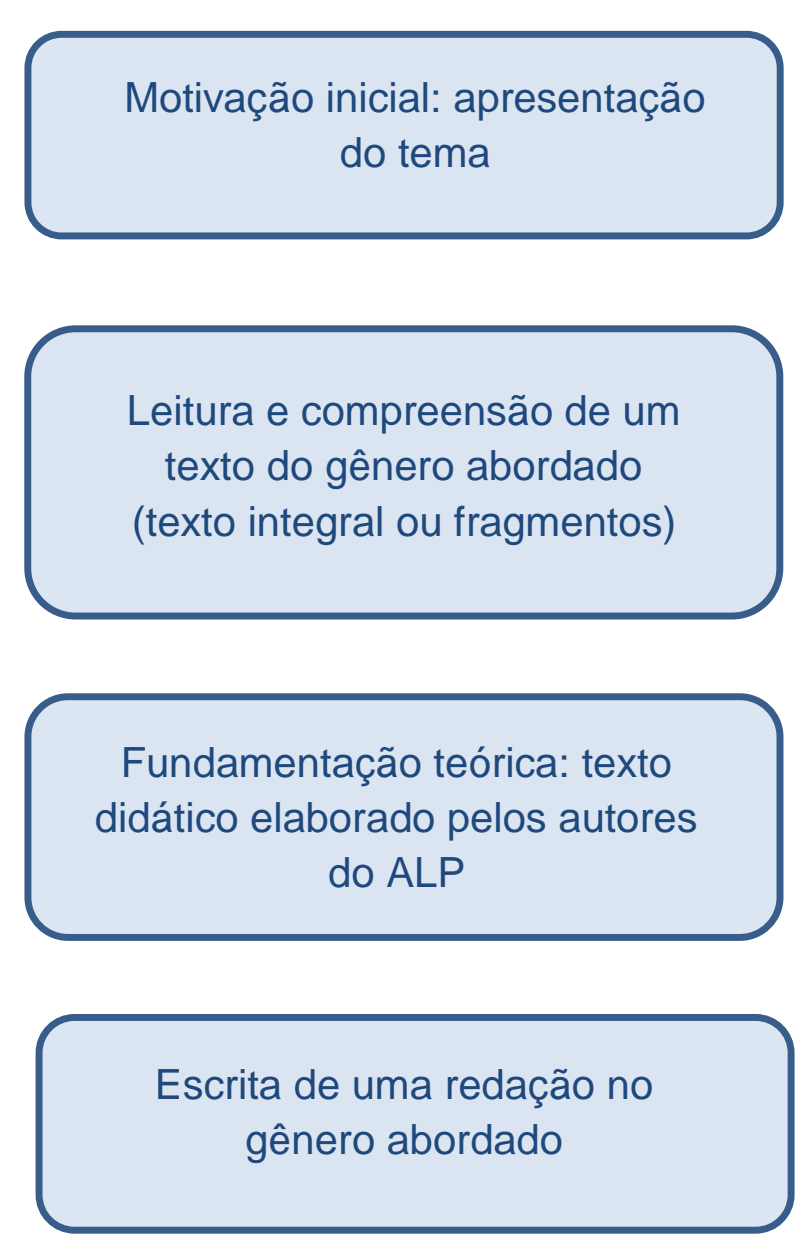

Esquema 1: Sequência didática das etapas de ensino do texto argumentativo no ALP

O relato da composição do objeto de estudo a partir da apresentação da justificativa de escolha do ALP como objeto de pesquisa e da descrição dos conteúdos prescritos, referentes ao ensino do texto argumentativo, permite a passagem para o aprofundamento de questões teóricas pertinentes à análise do objeto, apresentado no próximo capítulo. 


\section{CAPÍTULO 3}

\section{Ensino de texto argumentativo no apostilado de Língua Portuguesa}

A investigação do ensino do texto argumentativo no apostilado de Língua Portuguesa aponta para duas questões: (a) O que é texto? e (b) O que é argumentação? Neste trabalho, fundamentamos a análise com o apoio teórico do conceito de texto de Bakhtin e o Círculo (1926; 1928; 1929; 1952-53; 1959-61), articulado a outros conceitos do pensamento bakhtiniano - signo ideológico, enunciado e linguagem. A pertinência dessa escolha teórica se dá em razão de a concepção de linguagem do pensamento bakhtiniano explicar e responder aos questionamentos levantados a partir da observação do objeto de pesquisa.

No que diz respeito à argumentação, selecionamos três elementos da área dos estudos argumentativos denominada Nova Retórica, desenvolvida por Chaïm Perelman e Lucie Olbrechts-Tyteca, observados em Tratado da argumentação: a nova retórica (2005): (a) conceito de argumentação, (b) elementos necessários à argumentação e (c) procedimentos argumentativos utilizados na construção da argumentação. Os aspectos abordados contribuem de forma significativa para 0 aprofundamento da análise do objeto de pesquisa, uma vez que o encaminhamento 
das propostas de ensino de textos argumentativos no apostilado de Língua Portuguesa fundamenta-se teoricamente nesses conceitos.

O percurso teórico escolhido motivou a organização deste capítulo em duas partes: na primeira, discutimos o conceito de texto; e na segunda, aprofundamos o conceito de argumentação.

\subsection{Texto na concepção de Bakhtin e o Círculo}

A reflexão sobre texto parte da constatação de que esse conceito não se encontra pronto, dado em uma única obra, tampouco pode ser tomado isoladamente dos demais conceitos do Círculo de Bakhtin que com ele se articulam. A concepção de texto, nesta pesquisa, relaciona-se a outros três conceitos do pensamento bakhtiniano: signo ideológico, enunciado e linguagem, que contribuem para o aprofundamento da discussão teórica apresentada.

A escolha por discutir esses conceitos vincula-se às necessidades apontadas pelo objeto de análise. A investigação das relações estabelecidas entre o Currículo de Língua Portuguesa, o Caderno do Aluno e o Caderno do Professor, no que se refere ao encaminhamento das propostas de ensino de texto argumentativo, apresentadas no apostilado de Língua Portuguesa, parte da consideração desses três elementos como textos.

Nessa perspectiva, o Caderno do Professor, o Caderno do Aluno e o Currículo de Língua Portuguesa são social e historicamente determinados, apresentam autor e destinatários específicos e estão inseridos em uma cadeia de comunicação que responde a enunciados anteriores e suscita novas respostas.

A construção da reflexão sobre o conceito de texto parte das considerações apresentadas por M. Bakhtin, no conjunto de notas "O problema do texto na linguística, na filologia e em outras ciências humanas: uma experiência de análise filosófica" (1959-61), publicado na coletânea Estética da criação verbal (BAKHTIN, 2003) e articula-se às reflexões apresentadas em outras quatro obras do Círculo de Bakhtin: (a) Marxismo e filosofia da linguagem. Problemas fundamentais do método sociológico na Ciência da Linguagem (BAKHTIN/VOLOCHÍNOV, 1929), especialmente os capítulos $O$ estudo das ideologias e filosofia da linguagem; $A$ 
relação entre a infraestrutura e as superestruturas; Língua, fala e enunciação e $A$ interação verbal; (b) A palavra na vida e na poesia. Introdução ao problema da poética sociológica (VOLOCHÍNOV, 1926), ensaio publicado em Palavra própria e palavra outra na sintaxe da enunciação (VOLOCHÍNOV; BAKHTIN, 2011); (c) Os gêneros do discurso (BAKHTIN, 1952-53), publicado em Estética da criação verbal (BAKHTIN, 2003); (d) Os elementos da construção artística, capítulo da obra 0 método formal nos estudos literários: introdução crítica a uma poética sociológica (MEDVIÉDEV, 1928).

\section{Texto e signo ideológico}

Bakhtin esclarece que o texto, requisito essencial para a ocorrência da pesquisa na área das Ciências Humanas, é considerado "como qualquer conjunto coerente de signos" (BAKHTIN, 2003[1959-61], p. 307), o que significa considerar não apenas a dimensão verbal, mas também a visual e a verbo-visual como constitutiva do texto. Em qualquer das situações, o texto sempre aponta para fora de si mesmo, de onde decorre seu valor sígnico.

V. N. Volochínov estabelece a relação entre as ideologias e as questões pertinentes à filosofia da linguagem. O signo, para o autor, é todo objeto físico que reflete e refrata uma realidade que lhe é externa, sem deixar de lado sua materialidade, assumindo o caráter ideológico que lhe é constitutivo. Nessa concepção, o signo ideológico nunca é uma abstração da realidade. O signo existe apenas em sua concretude física e somente dessa forma pode ser analisado:

\footnotetext{
Todo fenômeno que funciona como signo ideológico tem uma encarnação material, seja como som, como massa física, como cor, como movimento do corpo ou como outra coisa qualquer. Nesse sentido, a realidade do signo é totalmente objetiva e, portanto, passível de um estudo metodologicamente unitário e objetivo. Um signo é um fenômeno do mundo exterior. O próprio signo e todos os seus efeitos (todas as ações, reações e novos signos que ele gera no meio social circundante) aparecem na experiência exterior. Este é um ponto de suma importância. (2004[1929], p. 33)
}

Um elemento natural, tecnológico ou de consumo torna-se um signo quando parte de uma realidade material e a reflete e refrata, ou seja, além de ser parte dessa realidade, o signo estabelece com ela relações de concordância, de 
discordância, de avaliação. Essas relações são determinadas de acordo com cada esfera ideológica, na qual o signo se insere e estão estreitamente ligadas à função social de cada esfera. Nesse sentido, o signo assume significado em comunicação direta com outros signos, que fazem parte de uma mesma cadeia:

Compreender um signo consiste em aproximar o signo apreendido de outros signos já conhecidos; em outros termos, a compreensão é uma resposta a um signo por meio de signos. E essa cadeia de criatividade e de compreensão ideológicas, deslocando-se de signo em signo para um novo signo, é única e contínua: de um elo de natureza semiótica (e, portanto, também de natureza material) passamos sem interrupção para um outro elo de natureza estritamente idêntica. (BAKHTIN/VOLOCHÍNOV, 2004[1929], p. 33-34)

Nessa cadeia comunicativa, o aspecto social da composição do signo assume grande importância. Em outras palavras, o signo ideológico só pode existir no processo de interação social, a partir da consciência individual, o que implica a constituição da consciência também como um fenômeno social, decorrente desse processo:

Todo signo resulta de um consenso entre indivíduos socialmente organizados no decorrer de um processo de interação. As formas do signo são condicionadas tanto pela organização social de tais indivíduos como pelas condições em que a interação acontece. (BAKHTIN/VOLOCHÍNOV, 2004[1929], p. 44)

A palavra é considerada o signo ideológico mais completo, uma vez que somente a palavra pode ser utilizada para comentar ou traduzir um fenômeno ideológico, seja ele de qualquer natureza, de maneira que toda função ideológica pode ser preenchida por ela, devido a sua neutralidade e capacidade de abarcar significados.

Por meio da palavra, o ser humano organiza seu discurso interior, necessário à sua constituição como ser social. Mesmo quando se trata da palavra interior, que ocorre no âmbito da consciência individual, ela é social, na medida em que a consciência se constitui na interação com o outro, de onde decorre a noção de psicologia do corpo social. De acordo com Bakhtin/Volochínov, 
as formas e aspectos da criação ideológica ininterrupta (...). A psicologia do corpo social se manifesta essencialmente nos mais diversos aspectos da "enunciação" sob a forma de diferentes modos de discurso, sejam eles interiores ou exteriores. (2004[1929], p. 42)

A psicologia do corpo social materializa-se na palavra que aponta todas as transformações sociais por meio de seu caráter ideológico. É por meio da palavra que as mudanças sociais emergem e tomam corpo, para mais tarde se estabelecerem como estruturas ideológicas mais complexas. Como signo ideológico, a palavra assume papel essencial na relação interindividual dos falantes, constituindo-se como "arena onde se desenvolve a luta de classes" (BAKHTIN/VOLOCHÍNOV, 2004[1929], p. 46) e, consequentemente, alavancando o processo de evolução social.

Desvinculada de seu contexto de origem, a palavra não pode significar, uma vez que a apreensão de seu sentido está vinculada à situação extraverbal da qual faz parte. Nesse sentido, a palavra não apenas reflete a compreensão do falante a respeito da situação, mas indica a valoração que o falante realiza no momento da comunicação, no qual deve ser considerada a participação ativa do outro com quem o falante se relaciona.

A palavra carrega uma entonação, um acento de valor que exprime o posicionamento ideológico do falante, constituída na fronteira do verbal e do extraverbal, na interação social e, portanto, apresenta dupla orientação: em relação ao ouvinte, participante ativo da situação de comunicação; e em relação ao próprio objeto de comunicação, considerado um elemento vivo, ativo e participante do processo de interação (VOLOCHÍNOV/BAKHTIN, 2011[1926], p. 154-155).

Para V. N. Volochínov, o caráter social da palavra por meio de um diálogo estabelecido com uma corrente de pensamento filosófico-linguístico vigente na época da elaboração da obra, o subjetivismo idealista. $O$ autor contrapõe-se à visão hegemônica de que a enunciação seria um ato puramente individual, como a expressão de uma consciência individual. Em sua visão, a expressão apresenta duas facetas: o conteúdo e a objetivação exterior, o que supõe um dualismo entre o que é interior e o que é exterior. 
Texto e enunciado

A segunda relação apontada por Bakhtin no conjunto de notas $O$ problema do texto na linguística, na filologia e em outras ciências humanas (1959-61) é a consideração do texto como enunciado:

O problema das fronteiras do texto. O texto como enunciado. (...) Dois elementos que determinam o texto como enunciado: a sua ideia (intenção) e a realização dessa intenção. (...) O texto como enunciado incluído na comunicação discursiva (na cadeia textológica) de dado campo. O texto como mônada original, que reflete todos os textos (no limite) de um dado campo do sentido. A concatenação de todos os sentidos (uma vez que se realizam nos enunciados). (BAKHTIN, 2003[1959-61], p. 308-309).

O conceito de enunciado é amplamente discutido por Bakhtin no ensaio Os gêneros do discurso (1952-53), dividido em duas partes, "O problema e sua definição", no qual o autor apresenta a noção de gênero do discurso e suas implicações teóricas, e "O enunciado como unidade da comunicação discursiva. Diferença entre essa unidade e as unidades da língua (palavras e orações)", no qual são evidenciadas as distinções entre a abordagem na perspectiva discursiva, com base no enunciado concreto, e a abordagem na perspectiva linguística, com base na palavra e na oração.

$\mathrm{Na}$ segunda parte do ensaio, o autor procura estabelecer as relações entre a linguística tradicional, pautada no estudo da palavra e da oração, e a abordagem enunciativo-discursiva, centrada no enunciado concreto, de modo a evidenciar os limites e os objetos de estudo de cada linha teórica.

A linguística tradicional considera a linguagem apenas do ponto de vista do falante, sem tecer as necessárias relações com o ouvinte, o qual também assume papel importante na comunicação. Na perspectiva bakhtiniana, a linguagem constróise nas relações sociais, e o ouvinte coloca-se como uma figura ativa e responsiva no processo comunicativo.

Bakhtin critica a indefinição e imprecisão terminológica a respeito do conceito de fala utilizado pelos linguistas em geral e atribui essa inconsistência ao desconhecimento da real unidade da comunicação discursiva, o enunciado concreto. Ainda de acordo com o autor, o discurso só pode existir por meio de enunciados, 
proferidos por sujeitos do discurso, em condições determinadas de produção. Esses enunciados possuem limites bastante precisos, definidos pela alternância dos sujeitos do discurso, relacionada à conclusibilidade específica de cada enunciado, e fazem parte de uma cadeia de outros enunciados proferidos ou que serão realizados, de modo a estabelecer com eles relações dialógicas.

Desse modo, o autor faz a distinção entre a oração, unidade da língua, e o enunciado, unidade da comunicação discursiva. A oração é considerada de maneira isolada, sem estabelecer relações com o contexto extraverbal ou com as orações de outros falantes. Já o enunciado concreto é constituído pelo aspecto linguístico, a exemplo das orações, e do extralinguístico. É delimitado pela alternância dos sujeitos falantes, tem contato com a realidade que o circunda, estabelece relações com os enunciados de outros falantes e é capaz de suscitar respostas.

A conclusibilidade específica do enunciado, considerada sua segunda peculiaridade, relaciona-se à possibilidade da adoção de uma postura responsiva a ele, e é determinada por três elementos: a exauribilidade semântico-objetal do tema do enunciado (o tratamento do tema), a vontade discursiva do falante (o que o falante quer dizer) e as formas típicas composicionais e de gênero do acabamento (a escolha do gênero para poder dizer).

A terceira peculiaridade do enunciado é sua relação com o próprio falante e com os outros participantes da comunicação discursiva. As escolhas realizadas pelo falante na produção de seus enunciados estão ligadas à construção dos sentidos que se quer obter, bem como com a relação valorativa que se estabelece entre o falante e seu objeto, responsável pelo elemento expressivo constitutivo do enunciado, ausente na oração.

A concepção de que cada enunciado é um elo na cadeia da comunicação discursiva, e, dessa forma, não pode ser considerado isoladamente, mas sempre em relação com os outros enunciados que o determinam, remete-nos a outro traço constitutivo do enunciado, a quem ele se dirige. O destinatário presumido do enunciado é determinado pelo campo de atividade humana do qual ele faz parte e determina, por sua vez, a constituição do enunciado: 
Portanto, o direcionamento, o endereçamento do enunciado é sua peculiaridade constitutiva sem a qual não há nem pode haver enunciado. As várias formas típicas de tal direcionamento e as diferentes concepções típicas de destinatários são peculiaridades constitutivas e determinantes dos diferentes gêneros do discurso. (BAKHTIN, 2003[1952-53], p. 305)

Interligado ao conceito de enunciado está o de gêneros do discurso, entendidos por Bakhtin como "tipos relativamente estáveis de enunciados" (BAKHTIN, 2003[1952-53], p. 262), determinados pelo uso efetivo que o falante faz deles de acordo com cada campo de atividade humana, que, por sua vez, determina a constituição de cada um dos três elementos indissociáveis do enunciado: conteúdo temático, forma composicional e estilo.

Segundo Bakhtin, se as especificidades do gênero não são consideradas, a abordagem linguística leva a uma abstração e a um formalismo que não são compatíveis com essa teoria. Nesse sentido, Campos afirma que

Entender o enunciado como unidade real da comunicação discursiva é compreendê-lo na interação verbal, em situação. A constituição do enunciado é dialógica e social: é produto da interação entre dois indivíduos socialmente organizados (2011a, p. 55)

Em relação a essas especificidades que estabelecem os gêneros do discurso como fenômenos concretos da cadeia comunicativa, observamos, ainda, como essa concepção de gênero consolida-se à de $P$. N. Medviédev em $O$ método formal nos estudos literários: introdução crítica a uma poética sociológica (1928), no texto "Os elementos da construção artística". Medviédev explicita a dupla orientação social do gênero:

Em primeiro lugar, a obra se orienta para os ouvintes e os receptores, e para determinadas condições de realização e de percepção. Em segundo lugar, a obra está orientada na vida, como se diz, de dentro, por meio de seu conteúdo temático. A seu modo cada gênero está tematicamente orientado para a vida, para seus acontecimentos, problemas, e assim por diante. (2012[1928], p. 195)

É possível afirmar que as duas orientações se projetam do gênero em direção à vida. A primeira diz respeito à sua exterioridade, ou seja, às condições de sua realização: a quem o gênero se dirige, em que tempo e espaço ele está situado, a que esfera ideológica ele está ligado, elementos que permitem o estabelecimento 
de uma interação entre falante e ouvinte. A segunda orientação, ligada à interioridade do gênero, relaciona-se às formas, estruturas e conteúdo temático do enunciado concreto, constituintes determinados também pela esfera ideológica na qual o gênero se insere.

Texto e linguagem

A terceira consideração a respeito de texto, também presente no conjunto de notas $O$ problema do texto na linguística, na filologia e em outras ciências humanas (1959-61), articula-se ao conceito de linguagem. É importante ressaltar que todas as peculiaridades apresentadas até o momento sobre a concepção de texto existem na e pela linguagem:

\footnotetext{
Cada texto pressupõe um sistema universalmente aceito de signos, uma linguagem. Se por trás do texto não há uma linguagem, este já não é um texto, mas um fenômeno das ciências naturais. (...) Portanto, por trás de cada texto está o sistema da linguagem. A esse sistema corresponde no texto tudo o que é repetido e reproduzido e tudo o que pode ser repetido e reproduzido, tudo o que pode ser dado fora de tal texto (o dado). Concomitantemente, porém, cada texto (como enunciado) é algo individual, único e singular, e nisso reside todo o seu sentido (sua intenção em prol da qual ele foi criado). (BAKHTIN, 2003[1959-61], p. 309-310)
}

Desse modo, é possível afirmar que texto e linguagem são indissociáveis. Nessa perspectiva, a linguagem é construída sobre dois polos. De um lado, entendida como sistema, permite que os falantes de uma mesma comunidade linguística se reconheçam como tal por meio dos elementos repetíveis em cada situação de comunicação. De outro, vista como um fenômeno vivo e mutável, possibilita a aparição de elementos não-repetíveis e singulares que contribuem para a sua evolução. De ambos os pontos de vista, a linguagem é social, na medida em que sua gênese e função estão intrinsecamente ligadas à interação social. Como sistema de signos partilhados pelos parceiros da comunicação, a linguagem nunca pode ser considerada algo imutável e definitivo. A consideração do ouvinte e a valoração que se faz da situação de comunicação na totalidade determinam a singularidade do evento linguístico a cada enunciação, o que se traduz como um elo na cadeia comunicativa. 
A partir disso, compreende-se que texto é considerado como um organismo vivo que carrega em si tanto traços comuns, que permitem que todos os falantes de uma determinada língua reconheçam elementos que possibilitam a comunicação, quanto traços singulares, que fazem de cada evento linguístico um fenômeno único e irrepetível:

\begin{abstract}
Assim, na prática viva da língua, a consciência linguística do locutor e do receptor nada tem a ver com um sistema abstrato de formas normativas, mas apenas com a linguagem no sentido de conjunto dos contextos possíveis de uso de cada forma particular. Para o falante nativo, a palavra não se apresenta como um item de dicionário, mas como parte das mais diversas enunciações dos locutores $A, B$ ou $C$ de sua comunidade e das múltiplas enunciações de sua própria prática linguística. (BAKHTIN/VOLOCHÍNOV, 2004[1929], p. 95)
\end{abstract}

Nesse sentido, texto não pode ser entendido como um fim em si mesmo, um produto estéril e estático, mas como algo vivo e mutável, que responde à situação em que se insere. Uma vez que o ser humano se constitui pela linguagem, é possível afirmar que as ações humanas se traduzem por meio de textos.

Depois de abordar a articulação dos conceitos do pensamento bakhtiniano no que diz respeito ao texto, trataremos da concepção de texto argumentativo no tópico a seguir.

\title{
3.2 Texto argumentativo
}

O ensino do texto argumentativo proposto no objeto de análise está baseado na discussão de algumas questões teóricas abordadas pela corrente de estudos em argumentação, denominada Nova Retórica, desenvolvida por Chaïm Perelman e Lucie Olbrecht-Tyteca, em Tratado da argumentação: a nova retórica (2005), citadas nas orientações apresentadas no Caderno do Professor. Surgida na segunda metade do século $X X$, essa vertente dos estudos em argumentação foi responsável, em grande parte, pelo ressurgimento da retórica, que passou a vigorar no campo das pesquisas sobre linguagem e argumentação. De acordo com Angenot,

Com esse renascimento na metade do século, a retórica, contígua às ciências da linguagem e da comunicação em pleno desenvolvimento, cessa de ser aquela que havia sido tradicionalmente; de uma aprendizagem da arte de debater bem e de discorrer com eloquência passa a se tornar aquilo 
que é hoje: o estudo dos discursos que circulam na sociedade sob o ângulo da argumentação (2012, p. 144).

Essa afirmação marca a importância da retórica para os estudos da linguagem e da argumentação. Nesse sentido, torna-se possível estabelecer pontos de contato entre o estudo do texto e o estudo da argumentação, de maneira que as contribuições das duas áreas enriqueçam a abordagem da questão apresentada nessa pesquisa, relacionada à investigação do ensino do texto argumentativo no apostilado de Língua Portuguesa do Estado de São Paulo.

Neste capítulo, traçamos um breve resgate histórico dos estudos sobre argumentação para o aprofundamento da discussão sobre texto argumentativo, com ênfase em alguns aspectos desenvolvidos pela retórica aristotélica, com a qual a Nova Retórica dialoga. Em seguida, procuramos responder às questões articuladas ao conceito de argumentação, apresentado no sistema apostilado de língua portuguesa, tendo por base a reflexão proposta por Perelman-Tyteca.

\section{A retórica aristotélica}

Aristóteles foi o responsável pela sistematização das reflexões sobre argumentação, iniciadas no século $V$ a.C. $O$ filósofo reformulou a retórica praticada em sua época, vista como a arte de bem falar e argumentar com as pessoas, ainda que os argumentos não estivessem fundamentados na verdade, integrando-a a um sistema filosófico diferente, segundo o qual a retórica não tinha a função de persuadir, mas "discernir os meios de persuasão mais pertinentes a cada caso" (ARISTÓTELES, 2005, p. 94).

Suas reflexões foram apresentadas na obra intitulada Retórica, composta por três livros. No livro I, Aristóteles sistematizou os três gêneros retóricos e apresentou uma análise da natureza das provas e meios de persuasão, enfatizando os argumentos lógicos. No livro II, apresentou provas e meios de persuasão que se baseiam nas emoções provocadas no auditório. O filósofo analisou novamente as formas de argumentação, privilegiando a estrutura lógica do raciocínio retórico construída com tópicos argumentativos e a utilização de máximas e entimemas. No livro III, analisou o estilo e a composição do discurso retórico. Além de elementos 
como clareza, correção gramatical e ritmo, o uso da metáfora e as partes que compõem um discurso também estão presentes neste livro.

No sistema retórico-aristotélico, a retórica é decomposta em quatro partes, representativas das fases por que passa a pessoa que compõe o discurso. A primeira parte, inventio, corresponde à busca dos argumentos e meios de persuasão, relativos à questão do discurso empreendida pelo orador. A segunda, dispositio, é a ordenação dos argumentos para a organização interna do discurso. A terceira, nomeada elocutio, diz respeito à escrita do discurso, e se relaciona à utilização das figuras de estilo. A quarta e última é a actio, que consiste na proferição efetiva do discurso, em que se destacam os efeitos de voz, ritmo e gestualidade.

A retórica se instalou na cultura ocidental como disciplina essencial, sendo prestigiada até o século $\mathrm{XVI}$, quando seu declínio teve início. O primeiro fator que contribuiu para esse novo quadro foi a separação da retórica e da dialética, o que reduziu a retórica ao estudo dos procedimentos estilísticos para a construção do discurso. No século XVII, René Descartes (1596-1650) desenvolveu um pensamento filosófico com base no questionamento das ideias, segundo o qual um evento ou fenômeno só existiria se pudesse ser provado. Com isso, a base da dialética foi destruída, enfraquecendo ainda mais a retórica. No século XIX, duas correntes de pensamento, o positivismo e o romantismo, rejeitaram veementemente a retórica, em nome da verdade científica e da sinceridade, respectivamente, relegando o que sobrara do sistema aristotélico ao esquecimento (REBOUL, 2004, p. 71).

Entretanto, menos de um século depois, a retórica renasceu na França e na Europa, em virtude do desenvolvimento dos meios de comunicação em massa. Dentre os estudiosos responsáveis por esse evento destaca-se o teórico Chaïm Perelman.

\section{A Nova Retórica}

Os resultados dos estudos de argumentação desenvolvidos por Chaïm Perelman e Lucie Olbrechts-Tyteca foram organizados na obra Tratado da argumentação: a nova retórica, publicada originalmente em francês, em 1958, pela 
Presses Universitaires de France. No Brasil, o livro teve sua primeira edição em 1996, publicado pela Editora Martins Fontes, e uma segunda edição em 2005, com tradução de Maria Ermantina de Almeida Prado Galvão e revisão da tradução de Eduardo Brandão.

Com base na reflexão teórica, proposta nessa obra, buscamos responder a três questões que sintetizam o percurso teórico-metodológico, adotado no ensino de argumentação proposto no objeto de análise: (1) O que significa argumentar?, (2) Quais são os elementos necessários à argumentação? e (3) Que procedimentos argumentativos podem ser utilizados na construção da argumentação?

De acordo com Perelman-Tyteca (2005), a Nova Retórica se propõe a "uma ruptura com uma concepção da razão e do raciocínio, oriunda de Descartes" (2005, p. 1), o que significa afirmar que o campo da argumentação não é o das evidências, mas o do verossímil. O objetivo dessa teoria é estudar "as técnicas discursivas que permitem provocar ou aumentar a adesão dos espíritos às teses que se lhes apresentam ao assentimento" (PERELMAN-TYTECA, 2005, p. 4), justificado pelo fato de que "as mesmas técnicas de argumentação se encontram em todos os níveis, tanto no da discussão ao redor da mesa familiar como no do debate num meio muito especializado" (PERELMAN-TYTECA, 2005, p. 8). Comparada à retórica clássica, a Nova Retórica apresenta pontos em comum, como a ideia de adesão e de auditório, e diferenças, na ênfase dada aos textos escritos.

O conceito de argumentação é dado em contraposição ao conceito de demonstração, que se relaciona à lógica formal, e se limita à apresentação e ao exame dos elementos que se constituem como prova. A argumentação, por outro lado, visa "influenciar, por meio do discurso, a intensidade de adesão de um auditório a certas teses" (PERELMAN-TYTECA, 2005, p. 16), o que justifica a preocupação com o estabelecimento de um contato intelectual com os indivíduos dos quais se pretende conseguir a adesão.

Alguns elementos tornam-se primordiais a fim de que a argumentação ocorra. Os elementos necessários à argumentação dizem respeito, em essência, à existência de uma questão a ser debatida bem como à disponibilidade do auditório em ouvir os argumentos do orador a esse respeito. $O$ orador, por sua vez, deve ter pleno conhecimento de seu auditório, de forma a se ajustar a ele na construção de 
sua argumentação. Assim, o auditório assume função primordial na medida em que a escolha dos argumentos está submetida à sua natureza (PERELMAN-TYTECA, 2005, p. 22-26).

Nesse sentido, o conceito de auditório universal ganha importância. O auditório universal, constituído pela humanidade como um todo, é representante do conjunto de crenças e valores específicos de uma determinada época e, por isso, os argumentos apresentados a esse tipo de auditório devem superar as expectativas e as objeções de qualquer auditório particular (PERELMAN-TYTECA, 2005, p. 37).

Nessa perspectiva, uma boa argumentação é aquela que, ao aumentar a adesão dos ouvintes àquilo que se apresenta, desencadeia neles uma ação ou, pelo menos, uma disposição para a ação, de acordo com a tese apresentada.

Para que a argumentação seja efetiva, é necessário o estabelecimento do acordo entre o orador e seu auditório. Para isso, o orador parte de objetos de acordo que podem servir de premissas, e, dessa forma, agrupados em duas categorias: a categoria do real, da qual fazem parte os fatos, as verdades e as presunções, caracterizados pelo acordo do auditório universal; e a categoria relacionada ao preferível, que comporta os valores, as hierarquias e os lugares do preferível, direcionados ao auditório particular.

$\mathrm{Na}$ argumentação, um evento só é considerado um fato quando é aceito pelo auditório universal sem controvérsias. Se houver questionamentos, o acontecimento perde seu estatuto de fato e não pode ser utilizado como premissa. A verdade é similar ao fato no que se refere à sua aceitação, mas designa sistemas mais complexos, tais como teorias científicas. As presunções representam o verossímil, ou seja, aquilo que se admite até que se prove o contrário.

Em relação à adesão de auditórios particulares, o valor pode ser entendido como algo que exerce uma influência determinada sobre a ação e as disposições à ação sem, no entanto, se impor a todos, mas considerando a multiplicidade de grupos. Estreitamente relacionadas aos valores estão as hierarquias que, do ponto de vista prático, permitem conferir maior intensidade aos valores utilizados na argumentação. Além dos valores e de suas hierarquias, o orador ainda pode contar com os lugares, espécie de agrupamentos de argumentos a fim de facilitar sua utilização (PERELMAN-TYTECA, 2005, p. 73-96). 
Ao garantir a ocorrência de uma situação propícia à argumentação, composta pela existência de uma questão a ser debatida e um auditório a ser persuadido, torna-se necessária a construção do percurso argumentativo, realizado por meio da escolha e elaboração dos argumentos, com a posterior apresentação deles. Na elaboração dos argumentos, dois processos podem ser utilizados: a ligação e a dissociação. Nos processos de ligação, os esquemas argumentativos aproximam elementos diferentes e permitem estabelecer relações de estruturação ou valorização. Nos processos de dissociação, são apresentadas técnicas de ruptura com o intuito de dissociar, separar, desunir elementos de um sistema de pensamento, modificando algumas das noções que constituem suas peças mestras (PERLEMAN-TYTECA, 2005, p. 215).

Na construção da argumentação, além da elaboração dos argumentos, são importantes as relações entre a escolha dos dados e sua interpretação, bem como a apresentação de certos aspectos desses dados, por meio da adequação da linguagem (PERLEMAN-TYTECA, 2005, p. 131-136). A interação e a ordem dos argumentos com a finalidade de fortalecer a argumentação devem ser consideradas, de forma a levar em conta o auditório e a recepção do discurso.

Nesse sentido, a ordem de apresentação dos argumentos também tem valor persuasivo, na medida em que

\footnotetext{
não se procura somente que a reflexão individual não se extravie em pistas erradas, mas também (...) que caminhos úteis não sejam prematuramente abandonados, ou seja, que se dê a certas premissas uma presença suficiente para que sirvam de ponto de partida para a reflexão. (PERELMAN-TYTECA, 2005, p. 558-559)
}

Três possibilidades da ordem dos argumentos podem ser utilizadas: a ordem crescente, que tem por inconveniente a apresentação de argumentos fracos logo de início, o que poderia indispor o ouvinte; a ordem decrescente, que começa pelos argumentos fortes, deixando os ouvintes com uma última impressão desfavorável ao orador, já que os argumentos mais fracos são apresentados por último; e a ordem homérica ou nestoriana, considerada a mais adequada, por começar e terminar o discurso com argumentos fortes, agrupando os mais fracos no meio da argumentação. 
A apresentação de alguns elementos pertinentes aos estudos de argumentação, segundo a Nova Retórica, mostra que a relação existente entre orador e auditório é essencial para a construção do percurso argumentativo em um texto. Nesse sentido, essa teoria estabelece pontos de contato com o pensamento bakhtiniano por considerar que tanto o falante como o ouvinte participam igualmente do processo de interação verbal:

o ouvinte, ao perceber e compreender o significado (linguístico) do discurso,
ocupa simultaneamente em relação a ele uma ativa posição responsiva:
concorda ou discorda dele (total ou parcialmente), completa-o, aplica-o,
prepara-se para usá-lo, etc.; essa posição responsiva do ouvinte se forma
ao longo de todo o processo de audição e compreensão desde o seu início,
às vezes literalmente a partir da primeira palavra do falante. Toda
compreensão da fala viva, do enunciado vivo é de natureza ativamente
responsiva (embora o grau desse ativismo seja bastante diverso); toda
compreensão é prenhe de resposta, e nessa ou naquela forma a gera
obrigatoriamente: o ouvinte se torna falante.(BAKHTIN, 2003[1952-53], p.
271)

A argumentação é entendida como uma atividade humana, constituída na interação entre os participantes da comunicação e, portanto, social. Sua realização pressupõe a afirmação de posicionamentos construídos na relação com o outro.

Com base nas considerações tecidas, no próximo capítulo, além de explicar como as concepções teóricas, aqui apresentadas, subsidiaram o desenvolvimento da pesquisa, mostraremos a análise do objeto selecionado. 


\section{CAPÍTULO 4}

\section{Propostas de produção de textos argumentativos no Caderno do Aluno}

Neste capítulo, o objetivo é apresentar as atividades didáticas escolhidas para a composição do objeto de pesquisa e, a partir da descrição, analisar as Situações de Aprendizagem que embasam o ensino do texto argumentativo e estabelecer as relações entre o que é prescrito no Caderno do Professor $(C P)$ e no Currículo de Língua Portuguesa (CLP) e o que efetivamente é proposto no Caderno do Aluno $(C A)$, no que se refere ao encaminhamento das atividades.

Conforme explicitado no capítulo 2, o objeto de pesquisa é composto por quatro Situações de Aprendizagem, retiradas de três volumes do total de doze apostilas que compõem o apostilado de Língua Portuguesa (ALP). Direcionamos o foco da pesquisa, em especial, para as atividades voltadas para o ensino do gênero argumentativo e a proposta de escrita do texto argumentativo.

Com base nos dados colhidos na descrição das Situações de Aprendizagem, estabelecemos três categorias de análise, equivalentes a cada etapa da proposta de ensino do texto argumentativo: a) leitura de textos no gênero abordado; b) fundamentação teórica apresentada; c) produção escrita do texto argumentativo.

A descrição e a análise de quatro Situações de Aprendizagem, que abordam o ensino de três gêneros: resenha, artigo de opinião e dissertação escolar, motivaram a organização deste capítulo em quatro partes. Na primeira parte, enfocamos a atividade intitulada "As vozes do outro e a nossa na resenha", 
destacada do volume 3 da $1^{\text {a }}$ série, que aborda o ensino de resenha. Na segunda parte, apresentamos a atividade "O que faz de alguém um escritor?", do volume 1 da $2^{\mathrm{a}}$ série, que trata do artigo de opinião. $\mathrm{Na}$ terceira parte, abordamos a terceira atividade, "Elaborando um projeto de dissertação" e a na quarta, a Situação de Aprendizagem "Momento de escrita: a redação de acesso ao ensino superior", ambas tiradas do volume 2 do apostilado da $3^{\text {a }}$ série, que enfocam a produção da dissertação escolar.

Analisamos o encaminhamento metodológico proposto no $C A$ para compreender de que modo o aluno é conduzido à produção do texto argumentativo; em seguida, verificamos se as orientações dadas no $C P$ contribuem para ajudar o aluno no desenvolvimento das habilidades e competências para a realização das atividades. Além disso, averiguamos se os atividades propostas no $C A$ e no $C P$ correspondem aos conteúdos prescritos no CLP no respeito ao ensino da produção de textos argumentativos.

\subsection{Análise A: "As vozes do outro e a nossa na resenha"}

De acordo com Machado (1996, p. 142-143), a resenha crítica, gênero pertencente à esfera jornalística, caracteriza-se pela realização de três operações discursivas: descrição, apreciação e interpretação. Na descrição, o objeto da resenha é descrito em detalhes, com a reprodução ou a reorganização de seus conteúdos. A apreciação é considerada como "o julgamento pessoal que se efetua sobre um determinado objeto, e pode ocorrer após a descrição ou em concomitância a ela". A interpretação consiste na explicação do objeto, na tentativa de se entender sua intencionalidade comunicativa.

No ALP, a resenha é ensinada na Situação de Aprendizagem "As vozes do outro e a nossa na resenha" (Vol. 3, $1^{\text {a }}$ série Ensino Médio). Na introdução apresentada no $C A$, a resenha é descrita como um "texto que apresenta um olhar específico dentro de uma determinada situação" (SÃO PAULO, 2010, $1^{\text {a }}$ série, Vol. 3 , p. 42). Propõe-se a participação do aluno no processo de construção da resenha, o que implica aprender a construir esse "olhar específico", de maneira que a "voz do outro" se faça presente. 
A atividade é composta por cinco páginas, com o objetivo de ensinar a escrever uma resenha, e organizada em seis seções:

1) "Leitura e Análise de Texto": leitura de uma resenha crítica e exercícios de compreensão;

2) "Lição de casa": leitura de texto didático com a fundamentação teórica sobre o gênero resenha;

3) "Projeto de resenha crítica": elaboração de projeto de escrita da resenha;

4) "Lição de casa": escrita da resenha crítica;

5) "Você aprendeu?": revisão do texto após correção do professor;

6) "Para saber mais": indicação de sites relacionados ao assunto abordado.

O esquema abaixo permite a visualização das etapas de ensino da resenha conforme a sequência das seções didáticas:
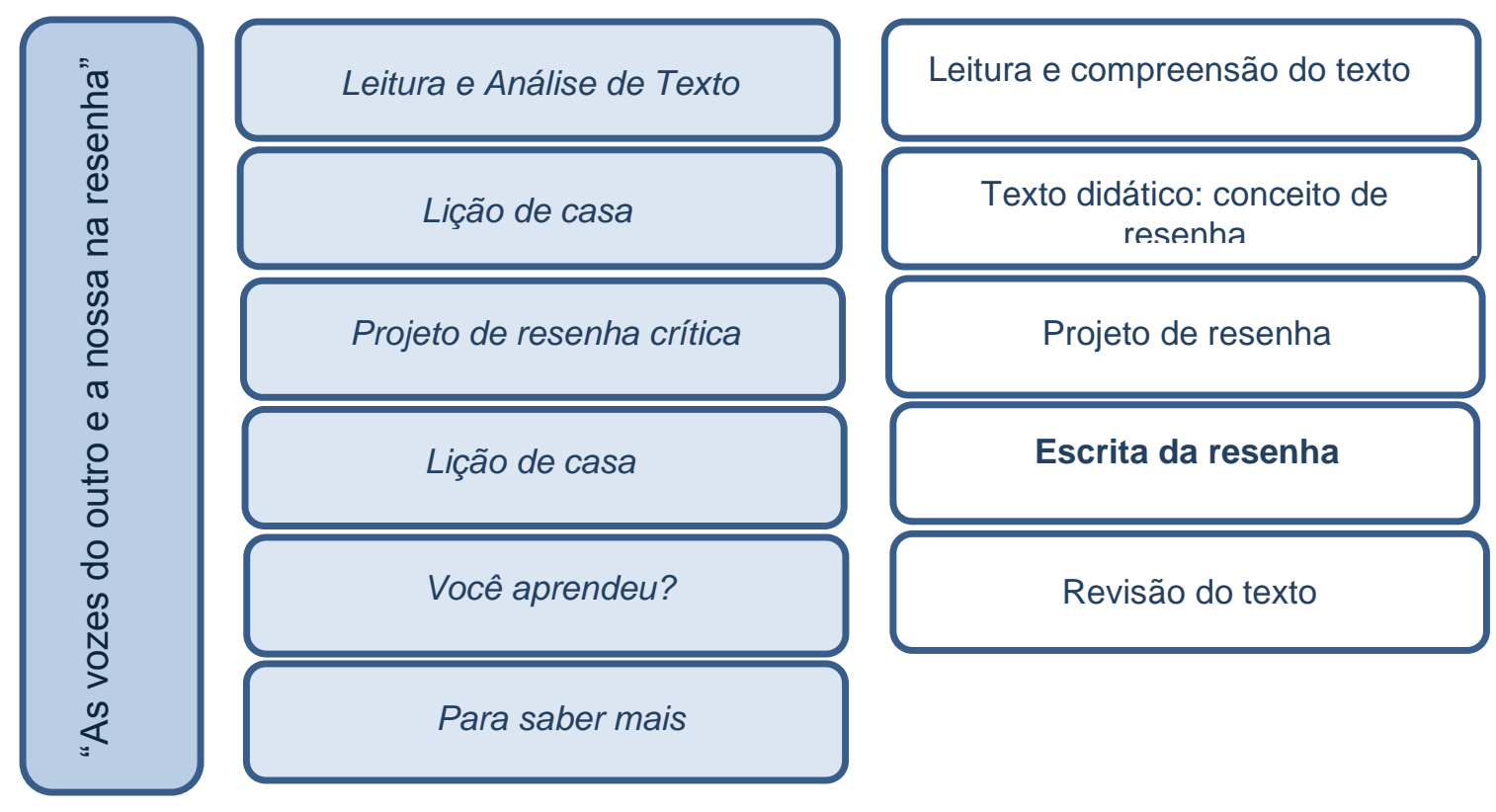

Esquema 2 - Seções didáticas e etapas de ensino na Situação de Aprendizagem "As vozes do outro e a nossa na resenha"

A macroestrutura apresentada mostra que as tarefas realizadas em casa assumem papel fundamental no aprendizado da resenha: o contato com o conceito do gênero resenha e a escrita da primeira versão do texto são realizados em casa. 
Na seção "Leitura e Análise de Texto", composta por quatro exercícios, apresenta-se a resenha "Márcia Castro combina arte e boa diversão". Antecipando a leitura, há um exercício de motivação, por meio do qual é oferecido ao aluno um objetivo para a realização da leitura: descobrir por que o autor da resenha, Lauro Lisboa Garcia, recomenda o show de Márcia Castro.

Em seguida, apresenta-se o texto na íntegra, retirado do jornal O Estado de S. Paulo, com a referência ao autor, ao jornal e à data de publicação no final. Informações como de qual caderno do jornal a resenha foi retirada e em que página ela se encontrava não são fornecidas. Como a composição verbo-visual na qual a resenha estava inserida, em sua publicação real, não é recuperada, as relações estabelecidas entre esse texto na materialidade original e os demais componentes da página do jornal são apagadas. Dessa forma, não se tem a compreensão de que a resenha é um texto que circula socialmente, uma vez que o texto é apresentado de maneira isolada, como uma das atividades propostas no $C A$, desvinculado de sua situação real de uso.

Depois da leitura, há três exercícios com três objetivos diferentes. No primeiro, busca-se a identificação de informações explícitas, tais como o nome do artista, as informações a respeito do espetáculo (local, data, horário), o ponto de vista do resenhista e o levantamento de hipóteses relacionadas à finalidade social da resenha. No segundo exercício, propõe-se a discussão de pontos de vista com base em uma afirmação do texto: "De qualquer maneira, esse combustível contribuiu para a performance". O trecho faz referência à possível ingestão de bebidas alcoólicas durante o show, o que poderia ter contribuído para o bom desempenho da cantora, segundo o resenhista. A proposta, nesse exercício, é que os alunos discutam se a resenha incentiva o uso abusivo de bebidas alcoólicas. No terceiro exercício, propõe-se que o aluno identifique o significado de um estrangeirismo utilizado no texto.

A segunda seção constitui-se como a primeira proposta de "Lição de Casa". $A$ atividade é composta por um texto com três parágrafos numerados, intitulado "O que é uma resenha?". O aluno deve sublinhar, no texto, as respostas para cinco perguntas dadas, organizadas de acordo com o parágrafo em que o aluno encontrará a resposta para cada uma delas: 
Parágrafo 1:

a) O que é uma resenha?

b) Para que serve?

Parágrafo 2: Qual é a diferença entre uma resenha e um simples resumo?

Parágrafo 3:

a) O que devemos evitar ao escrever uma resenha?

b) Quais são as partes obrigatórias de uma resenha?

(SÃO PAULO, 2010, 1aㅡ série, Vol. 3, p. 44)

No texto didático, não há indicação de referências bibliográficas, apenas a informação de ter sido preparado especialmente para circulação no apostilado. Observamos que os aspectos formais relativos à resenha - função, estrutura, diferença entre resenha e resumo - são priorizados. Além disso, entendemos que há a ressalva sobre a necessidade de apresentação da opinião do resenhista como elemento constitutivo desse gênero.

Ainda no que diz respeito à atividade sobre o gênero resenha no $C A$, observamos que as condições de produção, bem como a esfera de circulação, a recepção do texto e os efeitos de sentido estabelecidos na construção de um texto opinativo são aspectos deixados de lado. O processo de construção do texto opinativo não é abordado. Não há elementos da estrutura do gênero como parte do processo de construção do texto. Dessa forma, aspectos voltados para o modo como o aluno constrói a opinião no texto escrito, como os argumentos podem ser encontrados e organizados em uma resenha, como os marcadores argumentativos podem ser utilizados, não são mencionados. A abordagem do conceito de resenha como tarefa de casa exclui a intervenção do professor. A atividade, realizada de maneira individualizada, torna-se apenas um exercício de identificação de informações explícitas.

Na terceira seção, "Projeto de resenha crítica", a elaboração de um projeto de resenha a respeito de uma exposição realizada anteriormente é proposta com base nas orientações do professor. O objetivo da atividade é que o aluno planeje a escrita da resenha. Os critérios de correção e uma definição de projeto de texto de dissertação escolar são oferecidos ao aluno para a realização do projeto de resenha.

A definição de um projeto de dissertação escolar, acompanhando uma atividade de escrita de resenha, parece indicar a noção de que dissertação escolar e resenha, por serem textos opinativos, apresentam o mesmo percurso de 
planejamento e construção, sendo assim, semelhantes. Ainda que os gêneros abordados sejam diferentes, são apresentados ao aluno como sinônimos. A esfera de circulação de cada gênero, o destinatário presumido e as relações estabelecidas na cadeia comunicativa tecida por outros textos do mesmo gênero não são elementos considerados. As condições sociais e históricas da produção do gênero estão apagadas.

Depois de realizado o projeto de texto, há a indicação de uma segunda "Lição de Casa", a quarta seção da Situação de Aprendizagem, que consiste na escrita propriamente dita da resenha e o preenchimento de um quadro de avaliação com os critérios de correção mencionados anteriormente. Dois momentos essenciais na aprendizagem do gênero são relegados a tarefas de casa: o contato com o conceito de resenha e a produção do primeiro texto no gênero.

Depois da entrega e correção da resenha pelo professor, propõe-se a reescrita da resenha para nova entrega e segunda correção na quinta seção, intitulada "Você aprendeu?". Na parte final da atividade, a seção "Para saber mais" traz indicações de sites de quatro universidades (Pontifícia Universidade Católica do Rio Grande do Sul, Centro de Educação Superior do Rio grande do Sul, ligado à Universidade Federal de Santa Maria, Universidade Católica de Brasília e Universidade Federal da Bahia). Sugere-se dessa forma que os alunos busquem mais informações sobre a elaboração da resenha.

No $C P$, a Situação de Aprendizagem é apresentada com um conteúdo único: elaboração de resenha, a partir do trabalho com estratégias de leitura e elementos caracterizadores do gênero. Vale ressaltar a forma como o conceito de resenha aparece no CP: "gênero em que a voz do outro se apresenta com especificidades próprias que desafiam as habilidades de leitura e escrita" (SÃO PAULO, 2009, $1^{\text {a }}$ série, Vol. 3, p. 38). As orientações dadas ao professor, que compõem a Situação de Aprendizagem, são organizadas na atividade de motivação inicial, "Sondagem", seguida por quatro atividades.

$\mathrm{Na}$ "Sondagem", propõe-se ao professor que motive uma discussão oral, com o intuito de preparar os alunos para produção de opiniões fundamentadas a respeito de uma exposição de arte realizada por eles como resultado da Situação de Aprendizagem anterior. $O$ objetivo dessa atividade é verificar a capacidade de 
argumentação da turma, identificando os alunos com "maior habilidade e os que necessitam de atenção especial" (SÃO PAULO, 2009, 1ª série, Vol. 3, p. 39)

Em seguida, na "Atividade 1", são apresentadas cinco estratégias de leitura que devem ser desenvolvidas com os alunos:

1. Reconhecer o objetivo da leitura que se fará. Isso significa encontrar um objetivo para a leitura do texto.

2. Formular previsões e antecipações sobre o texto antes de começar a lêlo e durante o processo de leitura.

3. Interagir adequadamente aspectos materiais (como tamanho das letras, cor e textura do papel etc.), linguísticos (tais como vocabulário e estruturas morfossintáticas), enciclopédicos (o conhecimento de mundo) e contextuais (onde e como foi produzido o texto e como será lido).

4. Avaliar as previsões feitas com o que se vai conhecendo do texto. Avaliar as expectativas e (re)formular novas hipóteses.

5. Formular uma opinião sobre o que se leu.

(SÃO PAULO, 2009, $1^{\text {a }}$ série, Vol. 3, p. 39)

A primeira atividade é finalizada com a leitura e a compreensão da resenha apresentada. No fim da página, uma orientação com a rubrica "Para você, professor!" é fornecida. Os autores do ALP descrevem as atividades de compreensão como atividades de recuperação de informação explícita (questões 1 a 5) e de levantamento de hipóteses (questão 6). Nesta última atividade, propõe-se que os alunos reflitam sobre a função social da resenha, identificando-a como um texto que circula nos jornais. Uma vez que a resenha é apresentada desvinculada da página do jornal onde efetivamente foi publicada, entendemos que cabe ao professor informar ao aluno que a resenha aponta para um gênero pertencente à esfera jornalística.

Na "Atividade 2", aborda-se a utilização do vocábulo performance, indicando a promoção de uma discussão e a expressão das opiniões sobre a presença de incentivo ao alcoolismo no texto lido. Contudo, ainda que se promova o debate de ideias e a expressão de opiniões, não há um trabalho sistemático com o processo de construção de pontos de vista. Não observamos a preocupação com a maneira como a opinião do aluno pode ser construída, tampouco que mecanismos linguístico-discursivos podem ser utilizados para a elaboração de argumentos consistentes, tais como a utilização de marcadores argumentativos na construção da coesão textual e de verbos que explicitam causa e efeito, por exemplo. 
A terceira atividade consiste na explicação do gênero resenha. Para isso, os autores do ALP apresentam um texto didático composto por seis parágrafos. Verificamos que são apresentadas as características desse gênero, com ênfase para os aspectos formais e funcionais. Não há nenhuma referência bibliográfica ou indicação de leitura complementar, o que parece indicar ser um texto escrito pelos autores do material didático. A dimensão argumentativa da resenha é abordada nas seguintes passagens:

Trata-se de uma síntese que expressa a opinião do resenhista sobre determinado fato cultural (...).

A opinião apresentada, devidamente argumentada, pode ser favorável ou não ao fato cultural analisado.

(...) a resenha deve ir direto ao ponto, concentrando-se em provar, dentro do texto resenhado, a opinião do resenhista. Isso resulta em uma mistura, no corpo do texto, de alguns momentos de pura descricão com outros em que se faz uma crítica fundamentada. O objetivo é equilibrar (...) resumo e opinião pessoal.

(...) a resenha (...) deve apresentar as principais características do fato cultural, sem esquecer de argumentar os pontos de vista (...).

Não se esqueça de que uma resenha é um texto argumentativo, ou seja, deve ter um ponto de vista.

(SÃO PAULO, 2009, 1ª série, Vol. 3, p. 42, grifos nossos)

Observamos que há uma recorrência de termos pertencentes ao universo da argumentação nesse texto didático apresentado no CP ("opinião", "ponto de vista", "provar", "argumentar", "texto argumentativo"). No entanto, o campo semântico não aponta para propostas de desenvolvimento de habilidades argumentativas. Nessa atividade, ressalta-se que a resenha é um texto opinativo, em que o autor apresenta argumentos para provar sua opinião, porém, identificamos a ausência de procedimentos essenciais à construção da argumentação, exigida pelo CLP.

$\mathrm{Na}$ quarta atividade, o professor propõe a escrita da resenha sobre a exposição de arte realizada durante a Situação de Aprendizagem anterior, com base na elaboração prévia de um projeto de texto, informando aos alunos os seguintes critérios:

1. Presença dos elementos que compõem o gênero resenha.

2. Uso da norma-padrão da língua portuguesa, especialmente do verbo.

3. Veracidade das informações apresentadas e respeito aos direitos humanos.

4. Pertinência das opiniões apresentadas.

(SÃO PAULO, 2009, 1aㅡ série, Vol. 3, p. 43) 
Nas orientações dadas ao professor, a exemplo do que ocorre no $C A$, propõe-se a escrita de um texto em que sejam expostas as opiniões do resenhista. Observamos que não houve, para a realização da atividade, um trabalho sistemático de desenvolvimento da habilidade de construção e expressão da opinião no texto escrito, contrariando o que é prescrito no $C L P$. De acordo com o referencial curricular, uma das habilidades a serem desenvolvidas por meio das atividades que compõem o volume 3 do $C A$, do qual faz parte a sequência analisada, é "posicionarse criticamente diante do texto do outro, defendendo ponto de vista coerente a partir de argumentos" (SÃO PAULO, 2010, p. 84). Para que a tomada de posição crítica ocorra, seguida da elaboração coerente de argumentos, é preciso que o aluno tome contato com diferentes posicionamentos a respeito de textos diversos, de modo que se depare com caminhos variados para a construção da argumentação.

$\mathrm{Na}$ sequência de atividades descritas tanto no $C A$ quanto no $C P, 0$ tratamento dado ao gênero resenha não prioriza a construção das vozes sociais no texto, conforme anunciado no título da Situação de Aprendizagem. Ao desvincular a resenha de seu contexto de produção, oferecer um único texto para discussão e priorizar as características formais do gênero, o embate de vozes essencial à construção da argumentação é silenciado. Desse modo, a resenha apresentada torna-se, apenas, modelo a ser seguido.

Em um artigo em que analisa o ensino de texto argumentativo em materiais didáticos de língua portuguesa, Campos (2012, p. 223) afirma que "produzir um texto argumentativo exige a escolha de um gênero discursivo, o que significa ser fundamental considerar as esferas de circulação, de produção e de recepção do texto."

Ao transpor um gênero de sua esfera original de circulação, nesse caso, a jornalística, para a esfera escolar, torna-se impossível reproduzir todas as condições de produção inerentes ao processo de construção da resenha. No entanto, acreditamos ser possível a realização de um trabalho mais consistente no que se refere à construção das vozes sociais na resenha a partir da leitura e discussão de uma quantidade maior de textos, nos quais sejam enfocados os mecanismos linguístico-discursivos para expressão de pontos de vista. 
4.2 Análise B: "O que faz de alguém um escritor?"

O artigo de opinião é um gênero que circula na esfera jornalística e que tem como objetivo "convencer o outro de uma determinada ideia, influenciá-lo, transformar seus valores por meio de um processo de argumentação a favor de uma determinada posição assumida pelo produtor e de refutação de possíveis opiniões divergentes" (BRÄKLING, 2000, p. 226).

A Situação de Aprendizagem 2 "O que faz de alguém um escritor?" (Vol. 1, $2^{\mathrm{a}}$ série Ensino Médio), constituída por doze páginas, propõe ao aluno ler e escrever artigos de opinião a partir da sequência de nove seções:

1) "Para começo de conversa": introdução da Situação de Aprendizagem;

2) “Notícia ou opinião?”: distinção entre fato e opinião;

3) "Leitura e Análise de Texto": conceito de questão controversa; leitura de fragmentos de artigo de opinião para identificação de questão controversa;

4) "Lição de casa": identificação de questões controversas em frases;

5) "Leitura e Análise de Texto": leitura de um artigo de opinião para identificação de questão controversa e argumentos; proposta de escrita de artigo de opinião;

6) "Conectando o texto": abordagem dos conectores argumentativos;

7) "Lição de casa": leitura de texto didático sobre conectores e cruzadinha;

8) "Você aprendeu?": escrita de texto sintetizando os conceitos aprendidos na Situação de Aprendizagem;

9) "Para saber mais": indicação de sites para leitura de artigos de opinião e realização de simulados de vestibular. 


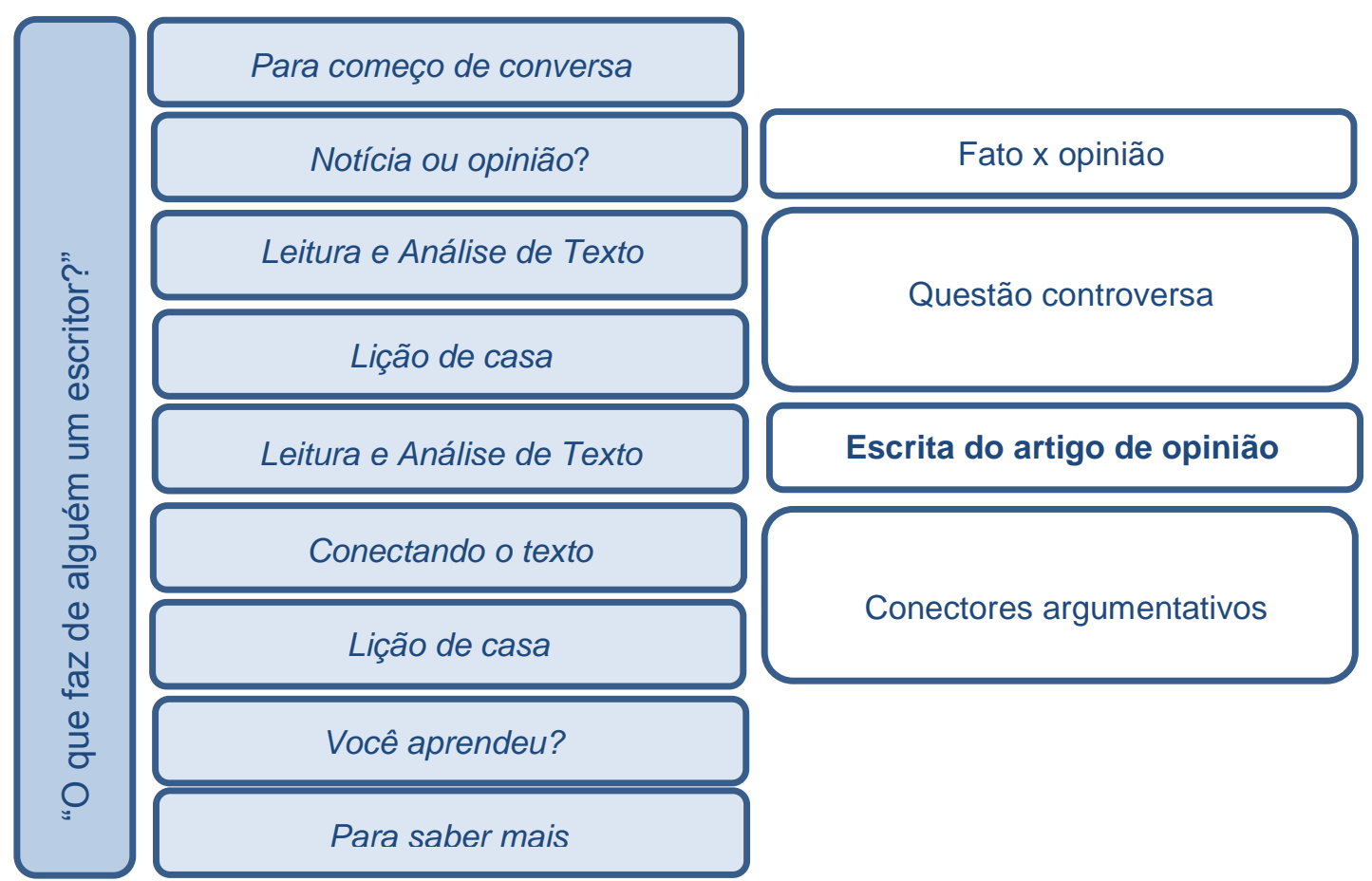

Esquema 3 - Seções didáticas e etapas de ensino na Situação de Aprendizagem "O que faz de alguém um escritor?"

A organização das seções mostra que o ensino do artigo de opinião baseiase na abordagem da distinção entre fato e opinião e na identificação de uma questão controversa para fundamentar o texto. Não é apresentado ao aluno um que conceitue artigo de opinião. O detalhamento das seções didáticas a seguir explicita o percurso metodológico seguido na Situação de Aprendizagem.

$\mathrm{Na}$ primeira seção, os autores do material didático justificam a escolha do artigo de opinião, relacionando-a ao desenvolvimento da crítica e da argumentação, importantes para a vida em sociedade e para o vestibular. No entanto, o artigo de opinião apresenta condições de produção, circulação e recepção bastante específicas, que o diferenciam da dissertação escolar, gênero ligado aos exames vestibulares. A vinculação do ensino da escrita do artigo de opinião ao vestibular indica a aproximação realizada no apostilado entre artigo de opinião e dissertação escolar, considerados gêneros semelhantes, a exemplo do ocorrido com o gênero resenha, conforme mencionamos na primeira parte deste capítulo.

Essa aproximação parece decorrer da desconsideração das esferas de circulação dos dois gêneros, a dissertação e o artigo de opinião; um circula na esfera escolar; o outro, na esfera jornalística. A ausência dessa distinção traz um questionamento em relação ao objetivo da atividade. As atividades propostas no $C A$ ao aluno objetivam que ele se torne um leitor e escritor fluente de artigos de opinião 
e, assim, possa escrever no jornal da escola/do bairro ou espera-se que ele apresente resultados melhores na avaliação SARESP a que é submetido ao final do Ensino Médio (EM)?

A primeira habilidade trabalhada na busca pela proficiência na leitura e escrita de artigos de opinião é a distinção entre os gêneros notícia e artigo de opinião, ambos pertencentes à esfera jornalística, apresentada na seção "Notícia ou opinião?".

A atividade parte do conhecimento prévio dos alunos a respeito das características do gênero notícia, trabalhadas na série anterior, contrapondo os dois gêneros com base na presença de elementos considerados constitutivos: fatos, em notícias, e defesa de posicionamentos, em artigos de opinião.

Para desenvolver a habilidade de "distinguir enunciados objetivos e enunciados subjetivos" (SÃO PAULO, 2010, p. 88), há três exercícios a partir da leitura de três fragmentos de textos retirados de notícias publicadas no jornal Folha de S. Paulo (Edições de 02/out/2003 e 18/set/2004) e de artigos de opinião publicados na revista Caros Amigos (Edição de agosto de 2001). No primeiro exercício, propõe-se ao aluno que ele identifique se o fragmento lido é parte de uma notícia ou de um artigo de opinião. No segundo exercício, o aluno deve justificar a resposta dada e no terceiro exercício, identificar nos trechos de artigos de opinião a questão discutida e o posicionamento do autor.

A seção "Notícia ou opinião?" é finalizada com uma discussão oral, realizada com base na leitura de duas frases, "A Terra é um planeta do sistema solar" e "O rap é uma música de mau gosto", nomeadas como enunciados no $C A$. O aluno deve estabelecer a diferença entre elas, de maneira a identificar qual das frases é apresenta um fato e qual delas apresenta uma opinião.

Na terceira seção, "Leitura e Análise de Texto", trabalha-se a identificação de questões controversas. De acordo com os autores do material didático, "uma questão controversa ou polêmica [é] uma afirmação cuja resposta não seja única, permitindo diferentes posicionamentos" (SÃO PAULO, 2010, 2ª série, Vol. 1, p. 15). A discussão de uma questão controversa também é considerada pelos autores um requisito essencial na construção de um texto argumentativo. 
Nessa seção, são propostos quatro exercícios a partir da leitura de fragmentos de artigos de opinião. Em seguida, o aluno deve identificar 0 posicionamento do autor no texto.

No primeiro exercício, propõe-se a leitura de dois parágrafos do texto "A redação e o vestibular", publicado no jornal Folha de S. Paulo (Edição de 17/02/2004) e escrito por um dos autores do apostilado, José Luís Landeira. A referência indica a data de publicação e o endereço eletrônico para acesso, além do nome do autor, do título do texto e do nome do veículo de publicação. Não é fornecido o nome do caderno do jornal em que o texto foi publicado.

No segundo exercício, pede-se que o aluno identifique o assunto tratado nos dois parágrafos apresentados. Em seguida, o aluno deve encontrar a opinião defendida pelo autor dentre quatro afirmações formuladas pelos autores do material didático e apresentadas no exercício. No terceiro exercício, o aluno identifica a questão controversa apresentada em três fragmentos de artigos de opinião publicados no site Gapa SP em 18 de setembro de 2004 e em duas edições da revista Caros Amigos (Edições 86 e 87, s/d). No quarto exercício, apresentam-se dois outros parágrafos não sequenciais do texto "A redação e o vestibular" e propõese ao aluno que ele estabeleça a relação existente entre o conteúdo desses parágrafos e daqueles dados no primeiro exercício. Em seguida, o aluno deve identificar a questão controversa apresentada no fragmento lido e a posição defendida pelo autor.

A identificação de questões controversas continua na quarta seção, "Lição de casa", composta por três exercícios. O primeiro e o segundo têm por base a leitura das seguintes orações para o reconhecimento de questões controversas:

a) A água é importante para a saúde da vida humana.

b) O trabalho infantil desrespeita os direitos da criança.

c) As drogas prejudicam a saúde.

d) A proibição do consumo de álcool reprime a liberdade.

e) Só a prevenção pode erradicar as DSTs em nossa sociedade.

No terceiro exercício, propõe-se ao aluno que ele leia e compreenda um artigo de opinião pesquisado em jornais, revistas, internet ou em livro didático, 
enfocando o assunto do texto e sua relação com o título, a questão polêmica e a adequação à utilização dos argumentos.

As atividades propostas como lição de casa reforçam a escolha por trabalhar as relações de sentido no nível da frase, o que parece bastante problemático, uma vez que tomada isoladamente e fora do contexto, a frase é uma abstração e não produz efeitos de sentido. De acordo com Bakhtin (2003[1952-53], p. 289), "a oração como unidade da língua, à semelhança da palavra, não tem autor. Ela é de ninguém, como a palavra, e só funcionando como um enunciado concreto ela se torna expressão da posição do falante individual (...)". O mesmo posicionamento a respeito da necessidade de textos reais e de efetiva circulação social para a construção de sentido é compartilhado pelo CLP:

\footnotetext{
A atividade de Língua Portuguesa deve evitar que o aluno se sinta um estrangeiro ao se utilizar de sua própria língua: é necessário saber lidar com os textos nas diversas situações de interação social. É essa habilidade de interagir linguisticamente por meio de textos, nas situações de produção e recepção em que circulam socialmente, que permite a construção de sentidos (SÃO PAULO, 2010, p. 30)
}

As atividades apresentadas para a identificação da questão controversa, considerada central na construção da argumentação, abordam os elementos da estrutura composicional do artigo de opinião. No entanto, observamos que os elementos que dizem respeito aos aspectos discursivos foram ignorados, como a apresentação de vozes controversas e a relação entre os interlocutores. Esses são aspectos significativos para que o aluno perceba o embate de posicionamentos. $A$ condução da atividade não leva à construção da criticidade, pois não há espaço para refutação ou concordância, apenas identificação de questões controversas. Esse encaminhamento contraria o que prescreve o CLP: o aluno deve "relacionar opiniões, temas, assuntos, recursos linguísticos, identificando o diálogo entre as ideias e o embate dos interesses existentes na sociedade" (SÃO PAULO, 2012, p.30).

$\mathrm{Na}$ quinta seção, "Leitura e Análise de Texto", o artigo "Passagem pela adolescência", de Rosely Sayão, publicado no jornal Folha de S. Paulo (Edição de 21/02/2008, Caderno Equilíbrio, p.12), é apresentado. Com base na leitura do texto, o aluno deve identificar a opinião defendida pelo autor e os argumentos 
apresentados. Em seguida, ele deve produzir um artigo de opinião em dupla, seguindo as orientações dadas pelo professor. Para a escrita do artigo de opinião, um roteiro de ações é fornecido, com a clara definição dos passos a seguir para a produção de um artigo:

3. Forme uma dupla com um colega. Com base em alguns temas sugeridos pelo professor, pensem em uma questão polêmica própria para um artigo de opinião e anotem no caderno.

4. Agora, identifiquem dois ou três argumentos que defendem essa questão polêmica ou tese.

5. Escolham um desses argumentos e encontrem um ou dois exemplos para ele.

6. Com as respostas dadas às questões anteriores, produzam um artigo de opinião. Ao elaborar o texto, certifiquem-se de que ele apresente os seguintes critérios para correção:

- ter aproximadamente 30 linhas;

- defender uma questão controversa por meio de argumentos;

- apresentar boa organização e clareza das ideias;

- ser escrito com letra legível.

(SÃO PAULO, 2010, 2ª série, Vol. 1, p. 19)

A atividade proposta dessa maneira conduz à produção de um texto em que o aluno segue um modelo. Três procedimentos transformam a produção do texto em uma atividade mecânica, um cumprimento de tarefas exigido pelo professor: a) a oferta de um único texto para leitura e identificação de tese e argumentos, desvinculado de sua origem; b) a sugestão de temas para a escrita do artigo, realizada sem aprofundamento, discussão ou leitura de outros textos motivadores; c) a apresentação de roteiro semelhante a uma receita, com a utilização do modo imperativo afirmativo. Mais uma vez, o encaminhamento metodológico proposto no $C A$ contradiz o que é prescrito no $C L P$ a respeito da produção de textos:

\footnotetext{
Não se trata de pensarmos em uma lista de características que compõem um modelo segundo o qual devemos produzir nosso texto, mas de compreender como esse texto funciona em sociedade e de que forma ele deve ser produzido e utilizado a fim de atingir o objetivo desejado (SÃO PAULO, 2010, p. 31).
}

Ao término da escrita, propõe-se que cada dupla de alunos leia o artigo de opinião produzido por outra dupla e sugira melhorias ao texto. Em seguida, com base nas sugestões dadas pelos colegas, a dupla deve revisar o texto e entregá-lo ao professor. Depois da correção realizada pelo professor, o texto deve ser reescrito e entregue novamente para a segunda correção. 
Após a escrita, revisão e reescrita do artigo de opinião, inicia-se a abordagem gramatical da situação didática na sexta seção, "Conectando o texto", composta por um exercício. Nessa etapa da Situação de Aprendizagem, enfatiza-se o uso dos conectores na produção do texto argumentativo. Para isso, oito fragmentos de textos distintos e isolados, formados por pequenos parágrafos, são fornecidos. Dentre eles, apenas um apresenta referência ao jornal Folha de $S$. Paulo, de 30 maio de 2004, sem nenhuma menção de que caderno, seção, página o fragmento foi retirado. Nesse caso, não há como identificar onde se encontra o texto original.

Em cada fragmento de texto, os conectores, nomeados organizadores textuais, são destacados. Propõe-se ao aluno que ele identifique o uso adequado do organizador textual por meio das seguintes expressões: "introduz argumento", "acresce argumento", "introduz conclusão", "introduz uma ideia na direção contrária ao que é afirmado antes".

A sétima seção "Lição de casa" é composta por dois exercícios. No primeiro, o aluno retira palavras destacadas de um texto nomeado "Progressão textual e conectores" para completar uma cruzadinha. O texto, constituído por dois parágrafos, sem indicação de fonte, trata da importância dos conectores na escrita do texto argumentativo. Além disso, o autor ressalta os diferentes sentidos estabelecidos pelos organizadores textuais na construção do texto.

No comando do segundo exercício, há uma situação fictícia protagonizada por uma personagem chamada Rebeca. Com base na "história de Rebeca", o aluno deve escolher entre duas frases qual será utilizada pela personagem para contar o ocorrido e justificar sua escolha com base no sentido produzido pelos conectores em cada situação.

Na oitava seção, "Você aprendeu?", propõe-se ao aluno a escrita de uma síntese dos assuntos abordados, seguida da leitura oral do texto produzido aos colegas da turma. Na última seção, "Para saber mais", sugere-se ao aluno a leitura do caderno Folhateen, parte integrante do jornal Folha de S. Paulo. O objetivo é que os alunos leiam conteúdos relacionados à adolescência. Além disso, sugere-se ao aluno que ele consulte o site do portal Universo Online (UOL), para a busca de simulados com questões de vestibulares. 
A Situação de Aprendizagem, conforme apresentada no $C P$, compõe-se da "Sondagem" e oito atividades. Na "Sondagem", o objetivo é verificar se os alunos diferenciam fatos e opiniões. Para isso, são fornecidos três fragmentos de texto retirados de jornais diversos, semelhantes aos apresentados no $C A$. A proposta é que os alunos identifiquem quais fragmentos fazem parte de uma notícia e quais fazem parte de um artigo de opinião.

Após a "Sondagem", há um roteiro com os conteúdos a serem desenvolvidos na atividade: a) conceito e definição de argumentação, considerando seu caráter dialógico; b) conceito de artigo de opinião, entendido como texto argumentativo; c) reflexão sobre o uso das conjunções na produção do texto argumentativo. De acordo com o roteiro apresentado, para que se atinja o objetivo proposto, deve-se abordar o artigo de opinião, considerado como um texto argumentativo, enfocando seu caráter dialógico, ou seja, explorando as relações estabelecidas com outros textos do mesmo gênero e com os demais textos (de gêneros diversos) que compõem a página do jornal na qual o artigo de opinião circula.

Na "Atividade 1", apresentada no CP, define-se o que são fatos e opiniões e discute-se o que é argumentação a partir de três fragmentos de textos de referência. O primeiro fragmento é de autoria de Jacqueline $P$. Barbosa, e compõe o material preparado pela Secretaria da Educação entre 2004 e 2006, para o programa "Ensino Médio em Rede". No $C P$, esse material é indicado como recurso de ampliação de conhecimentos ao professor na última página do volume. O segundo fragmento é extraído da obra Tratado da argumentação: a nova retórica, de Chaïm Perelman e Lucie Olbrechts-Tyteca. O último apresenta apenas uma frase do texto "A vida em uma sociedade letrada", de Maria Luiza M. Abaurre ${ }^{7}$, que integra a publicação destinada aos estudantes que fizeram o Exame Nacional para Certificação de Competências de Jovens e Adultos (Encceja) em 2002.

Na "Atividade 2", é fornecido ao professor um texto didático com explicações sobre o que é uma questão controversa, definida como "a afirmação cuja resposta não seja única, permitindo, então, que se assumam diferentes posicionamentos" (SÃO PAULO, 2009, 2a série, Vol. 1, p. 21). Nas "Atividade 3" e "Atividade 4", é

\footnotetext{
7 ABAURRE, Maria Luiza M. A vida em uma sociedade letrada. In: MURRIE, Z. F. (Coord.). Linguagens, códigos e suas tecnologias: livro do estudante: Ensino Médio. Brasília: MEC/Inep, 2002, p. 95-97.
} 
pedido que o professor proponha ao aluno a leitura de fragmentos de artigos de opinião para que se encontre a questão controversa, o argumento de sustentação da tese e o exemplo utilizado pelo autor. $\mathrm{Na}$ "Atividade 5", é oferecido o primeiro texto integral para que o procedimento se repita: leitura, identificação de questão controversa e de argumentos.

A "Atividade 6" corresponde à proposta de escrita do artigo de opinião realizada em duplas, com a indicação dos critérios de correção. Não é apresentada qualquer espécie de roteiro, como ocorre no CA. A "Atividade 7" e a "Atividade 8" abordam o uso de conectores na produção do texto argumentativo. No final da "Atividade 8", sugere-se ao professor a elaboração de outros exercícios com conectores a partir de artigos de opinião retirados de jornais. No encaminhamento sugerido, o professor pode retirar os conectores do texto, organizá-los em um quadro à parte e orientar os alunos a preencher as lacunas com os conectores adequados.

Propõe-se ao professor que ele priorize a abordagem reflexiva de uso das conjunções na construção do texto argumentativo, evitando a memorização exaustiva. Entretanto, conforme observado nas propostas de exercícios apresentadas no $C A$, o enfoque dado não é na construção do texto, e sim, na relação entre as frases. $O$ fragmento seguinte, retirado do $C P$, mostra que a orientação dada para o professor não corresponde ao que é proposto ao aluno, em relação ao trabalho com os conectivos:

\footnotetext{
A continuidade do texto envolve a progressão daquilo que se diz. Ao escrever um texto argumentativo, não podemos apenas "encher" linhas, mas procuramos defender uma questão controversa por meio de argumentos já selecionados. A continuidade de sentidos (...) exige a articulação entre as diferentes partes do texto por meio do uso adequado de conectivos (SÃO PAULO, 2009, 2ª série, Vol. 1, p. 26)
}

A abordagem gramatical focada no uso dos conectores, ainda que apresente elementos que auxiliam na construção do texto argumentativo, como a reflexão sobre os sentidos estabelecidos por meio de cada organizador textual, não é considerada parte constitutiva do processo de produção do texto. Na sequência analisada, o trabalho com os conectores tem início depois da escrita do texto, contrariando os objetivos propostos no roteiro de aplicação da Situação de 
Aprendizagem, apresentado no CP. Vale ressaltar que dentre os objetivos propostos no $C P$ destaca-se aquele em que o aluno deve aprender a "usar de modo reflexivo os conectores, especialmente as conjunções, na produção de um texto argumentativo" (SÃO PAULO, 2009, $2^{\mathrm{a}}$ série, Vol. 1, p. 20).

No $C P$, a proposta de escrita do artigo de opinião não é guiada por um roteiro de passos, como ocorre no $C A$. Ao contrário, nenhuma instrução de como deve ser escrito o artigo é dada, a não ser o comando "produzam um artigo de opinião". Nos dois materiais, a ausência de discussão a respeito dos temas propostos, a oferta de um único texto para leitura e contato com o gênero e a falta de uma abordagem consistente a respeito da construção da argumentação inviabilizam a escrita no qual o aluno, de fato, tome um posicionamento diante dos fatos e expresse seu ponto de vista.

\subsection{Análise C: "Elaborando um projeto de dissertação"}

A dissertação tem sua origem na esfera escolar, como um objeto de ensino da escrita. Atualmente, sua produção e circulação ultrapassam a sala de aula e atingem os processos seletivos de ingresso no Ensino Superior, nos quais é requisitada sua produção (SOUZA, 2003, p. 163). Na dissertação escolar, o aluno discorre sobre um determinado tema, produzindo um texto em que seu ponto de vista é defendido de maneira lógica e consistente, fundamentado na articulação coerente de ideias. De acordo com Souza (2003, p. 164), "a dissertação deve ser produzida com verdadeira intenção comunicativa, na qual o escritor tem consciência de que seu ponto de vista será submetido à apreciação de outros leitores".

No ALP, o ensino da dissertação escolar é realizado na 3aㅗ série do Ensino Médio, por meio de duas Situações de Aprendizagem que se complementam: a situação 2, intitulada "Elaborando um projeto de dissertação" e a situação 4, "Momento de escrita: a redação de acesso ao Ensino Superior", apresentadas no volume 2 do apostilado. Na primeira atividade, os alunos realizam um planejamento da escrita por meio de um projeto de texto; na segunda, efetuam a escrita propriamente dita da dissertação escolar. 
Em "Elaborando um projeto de dissertação", três conteúdos centrais são apresentados: a) estrutura sintática da tese; b) características da dissertação escolar, considerada como texto argumentativo; c) planejamento da escrita. Para atingir aos objetivos propostos, a atividade didática organiza-se em dez seções, apresentadas da seguinte maneira no $C A$ :

1) "Para começo de conversa": estrutura sintática da tese;

2) "Lição de casa": estrutura sintática da tese;

3) "Um gênero argumentativo: a dissertação escolar": conceito de dissertação escolar;

4) "Preparando o caminho para o texto": organização de argumentos;

5) "Lição de casa": conectores argumentativos;

6) "A leitura para construir a argumentação": coletânea de textos para a escrita da dissertação;

7) “Lição de casa”: coletânea de textos para a escrita da dissertação;

8) "Produzindo seu projeto": elaboração do projeto de texto de dissertação escolar;

9) "Lição de casa": conceito de argumentação e texto dissertativo;

10) “Você aprendeu?”: escrita de texto explicando o que é dissertação escolar. 


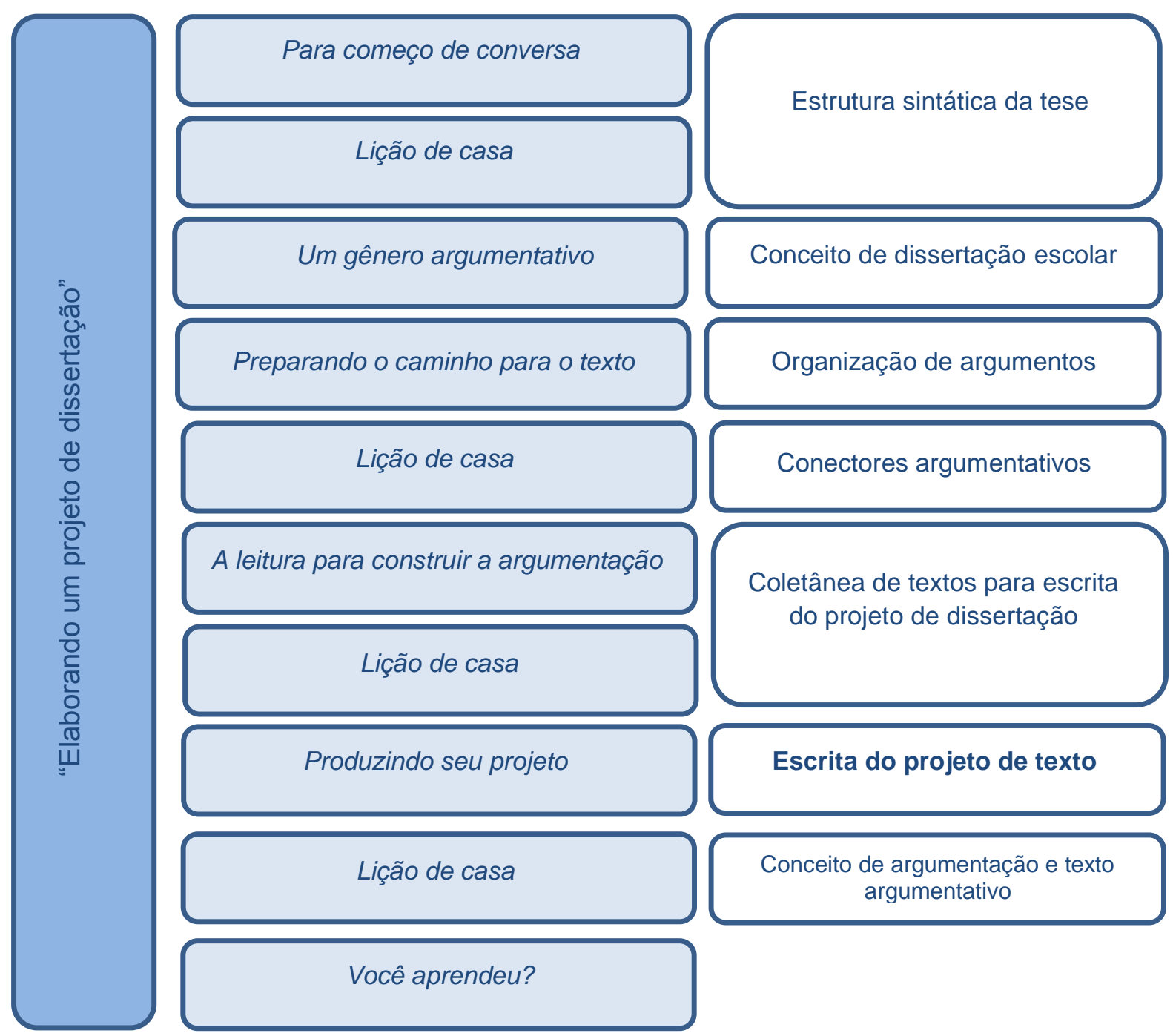

Esquema 3 - Seções didáticas e etapas de ensino na Situação de Aprendizagem "Elaborando um projeto de dissertação"

Na primeira seção, "Para começo de conversa", há uma discussão inicial seguida de quatro exercícios. A atividade que compõe a discussão inicial é intitulada "Tipologia textual: a argumentação", e apresenta profissões que exigem uma formação específica no Ensino Superior, organizadas em seis áreas do conhecimento: Ciências Humanas e do Conhecimento; Engenharias; Ciências Exatas; Ciências Biológicas; Ciências Agrárias; Artes. Depois dessa apresentação, o aluno é questionado a respeito de suas escolhas em relação à profissão que gostaria de seguir.

Em seguida, propõem-se quatro exercícios nessa seção do $C A$. No primeiro, são apresentadas quatro frases-síntese que devem ser relacionadas a três 
parágrafos do texto "Tecnologias de Comunicação e Informação: presença constante em nossas vidas" ${ }^{\text {, }}$ de Paulo Marcelo Vieira Pais, publicado no livro do estudante direcionado aos jovens que se preparavam para a avaliação de obtenção de certificado de conclusão do ensino médio em 2006.

O segundo exercício inicia-se com a apresentação de um artigo de opinião escrito por José Luís Landeira, um dos autores do material didático de português, publicado apenas no apostilado, para que o aluno reconheça a tese defendida no texto por meio da escolha de uma dentre quatro alternativas apresentadas. Em seguida, o aluno deve identificar um argumento utilizado no texto para a defesa da tese e explicar como os objetivos do autor são atendidos. Por fim, o aluno elabora uma tese para cada um dos sete temas apresentados - violência, aborto, sexo, leitura, política, pena de morte e imprensa -, evidenciando sua posição em relação a cada questão.

A utilização de um artigo de opinião fictício, elaborado apenas para a publicação no material do aluno, vai de encontro às diretrizes apresentadas nos referenciais curriculares nacionais e ao próprio $C L P$, que orientam para o trabalho com textos reais, de efetiva circulação em sociedade. Além disso, utilizar um artigo de opinião em uma atividade didática que tem por objetivo ensinar a dissertação escolar reforça a consideração de que os gêneros artigo de opinião e dissertação escolar são iguais, já que são textos opinativos.

Na segunda seção, "Lição de Casa", dois exercícios que abordam a construção de tese são apresentados. No primeiro, o aluno identifica em um grupo de seis frases aquelas que mantêm a estrutura apresentada pelos autores do ALP como sendo a mais adequada à construção da tese: sujeito + verbo/locução verbal + complementos ou predicativos. No segundo exercício, o aluno deve escrever um argumento para cada uma das quatro teses apresentadas. A elaboração dos argumentos deve ser realizada a partir da apresentação, no $C A$, de um modelo de argumento ("Bons amigos melhoram nosso humor, o que nos traz melhor saúde.") que defende uma tese ("Boa saúde depende também de bons amigos").

\footnotetext{
${ }^{8}$ PAIS, Paulo Marcelo Vieira. Tecnologias de comunicação e informação: presença constante em nossas vidas. In: Linguagens, códigos e suas tecnologias: livro do estudante (Ensino Médio). MURRIE, Zuleika F. (coord.). Brasília: MEC: INEP, 2006. p.157.
} 
$\mathrm{Na}$ série anterior, na atividade relacionada à escrita do artigo de opinião, o conceito de tese foi apresentado como sendo o de uma afirmação cuja resposta não seja única. No entanto, as "teses" apresentadas ao aluno nesse exercício não admitem réplica ou questionamentos, visto serem afirmações amplamente aceitas em sociedade, descaracterizando a essência de uma questão controversa.

A proposta para que a elaboração dos argumentos seja realizada em casa, sem que tenham sido trabalhadas, em aulas, estratégias argumentativas (argumentação pelo exemplo, argumento de autoridade, relações de causa e consequência, analogias etc.), com a orientação "Siga o modelo", na sequência de um exercício que trabalha com a ordem direta de frases, reduz a construção de teses à elaboração de afirmações formadas por sujeito + verbo/locução verbal + complementos/predicativos.

$\mathrm{Na}$ terceira seção da Situação de Aprendizagem, "Um gênero argumentativo: a dissertação escolar", apresenta-se o gênero dissertação escolar ao aluno por meio de dois exercícios. No primeiro, o aluno examina três recortes de propostas de redação de vestibular, nos quais são apresentados apenas os comandos da atividade, para identificar e anotar em seu caderno os pontos em comum entre elas. No segundo exercício, com base nas orientações do professor, o aluno é motivado a "definir, com suas palavras, o conceito de dissertação escolar como gênero dissertativo" (SÃO PAULO, 2010, $3^{\mathrm{a}}$ série, Vol. 2, p. 21, grifos dos autores).

$\mathrm{Na}$ quarta seção, "Preparando o caminho para o texto", o aluno realiza dois exercícios nos quais aplica os conhecimentos adquiridos na seção anterior, preparando-se para a escrita do projeto de texto dissertativo. Como introdução aos exercícios, há um parágrafo em que se aponta a necessidade de esclarecer o sentido das palavras-chave utilizadas em um texto argumentativo. Esse esclarecimento, segundo os autores do ALP, pode ser realizado de duas maneiras: a) definindo-se as palavras-chave; e/ou b) estabelecendo quais aspectos ou situações são discutidos. No primeiro exercício, com base na tese apresentada no parágrafo introdutório ("A violência das cidades conduz a sérios problemas familiares"), o aluno deve responder a duas questões que envolvem a definição de palavras-chave e a delimitação do tema. 
Entre o primeiro e o segundo exercícios, os autores apresentam, em uma caixa de texto, nomeada "Aprendendo a aprender", a definição de argumentação como "um processo textual que exige organização: os argumentos devem se encadear uns aos outros, dando ao leitor a sensação de unidade" (SÃO PAULO, 2010, 3ํㅗㄹ série, Vol. 2, p. 22, grifo dos autores).

No segundo exercício, uma situação fictícia é apresentada, na qual um estagiário de um jornal é convidado a escrever um artigo de opinião, dirigido a jovens e adolescentes. Para isso, ele pede a ajuda de uma amiga jornalista. $O$ exercício é dividido em quatro itens. No primeiro, o aluno deve escrever as falas dessa personagem, de modo a completar o diálogo entre o estagiário e a jornalista. No segundo, depois de ler os três argumentos oferecidos no $C A$, o aluno deve opinar sobre a qualidade desses argumentos, considerando o leitor do artigo. No item seguinte, um quadro contendo o projeto de texto (tema, tese, termos que são definidos no texto, argumentos) deve ser completado com a hierarquização dos três argumentos apresentados no segundo item. No último item, o aluno deve justificar as escolhas realizadas no terceiro item.

$\mathrm{Na}$ seção seguinte, a segunda "Lição de Casa", aborda-se o uso de conectores no texto argumentativo. No primeiro exercício, o aluno relaciona duas colunas, associando verbos no infinitivo ("concordar"; "duvidar"; "dar certeza"; "alternar") a quatro grupos de conectores. No segundo, sete conectores diferentes devem ser encontrados em um caça-palavras e utilizados para completar uma carta de amor à língua portuguesa, especialmente escrita para compor o exercício.

A sexta seção, "A leitura para construir a argumentação", é formada por quatro atividades: a) uma discussão oral; b) a leitura de um poema, seguida de três atividades de compreensão; c) uma segunda discussão oral; d) um quadro com informações sobre o autor do poema, intitulado "Aprendendo a aprender". As atividades dessa seção fornecem repertório para que o aluno possa escrever seu projeto de texto dissertativo.

Na primeira discussão oral, com base em duas perguntas, o aluno relembra o conteúdo trabalhado na Situação de Aprendizagem anterior, em que se tratou da obra Vidas Secas, de Graciliano Ramos, e discute a função social de um poema. Na 
segunda atividade, depois de lido o poema $O$ açúcar ${ }^{9}$, de Ferreira Gullar, o aluno realiza três exercícios: uma síntese das ideias mais importantes do poema, uma atividade de múltipla escolha, na qual identifica o sentido de um adjetivo utilizado no texto, e a escrita de um parágrafo explicando a relação entre o sentido do poema e a crítica da sociedade. Na segunda discussão oral, o aluno define trabalho escravo na atualidade. No quadro "Aprendendo a aprender", dados biográficos de Ferreira Gullar são apresentados.

A coletânea de textos para a elaboração do projeto de dissertação é completada com a proposta de "Lição de Casa", sétima seção da Situação de Aprendizagem, em que o aluno realiza dois exercícios: a) escreve um poema que critique uma injustiça social, seguindo o estilo de Ferreira Gullar; b) lê apenas o $22^{\circ}$ parágrafo do texto "O que é trabalho escravo"10, publicado no site de uma organização não-governamental, envolvida com a denúncia de trabalho escravo no Brasil, e relaciona-o ao poema.

Na oitava seção, "Produzindo seu projeto", o aluno é orientado a completar um quadro de planejamento do projeto de texto argumentativo, com base na leitura dos textos apresentados. No quadro, que segue o modelo fornecido no segundo exercício da seção "Preparando o caminho para o texto", são preenchidas as seguintes informações: a) tese; b) termos que vou definir no texto; c) argumento menos importante (1); d) argumento médio (2); e) argumento mais importante (3).

A atividade é seguida por uma última "Lição de Casa", a nona seção, na qual o aluno é orientado a procurar definições de argumentação e texto dissertativo em livros didáticos de português. Em seguida, deve selecionar aquelas que julgar mais importantes, comparar com as anotações realizadas em aula e elaborar uma lista definitiva. Na décima e última seção, "Você aprendeu?", o aluno aconselha uma personagem fictícia a respeito da elaboração da redação no ENEM.

No CP, a Situação de Aprendizagem é composta pela "Sondagem" e por três atividades. Na "Sondagem", verificam-se as expectativas dos alunos a respeito dos exames de acesso ao Ensino Superior por meio de perguntas a respeito dos planos de continuidade dos estudos. Na "Atividade 1", propõe-se ao professor a

\footnotetext{
${ }^{9}$ GULLAR, Ferreira. Toda poesia. Rio de Janeiro: José Olympio, 2006.

${ }_{10}$ Repórter Brasil. Agência de Notícias. Disponível em:
} http://www.reporterbrasil.org.br/conteudo.php?id=4. Acesso em: 05 dez 2012. 
apresentação de três recortes de propostas de redação de vestibular ao aluno. Nesses recortes, apenas os comandos da atividade são apresentados, para que o aluno identifique e anote em seu caderno os pontos em comum entre as diferentes propostas de redação de vestibular.

$\mathrm{Na}$ "Atividade 2", são fornecidos elementos para que os alunos entendam o que é um texto argumentativo. Um texto didático é apresentado, sem referências bibliográficas. De acordo com o texto, transcrito apenas no $C P$, "o que as instituições de Ensino Superior compreendem como 'texto argumentativo' é aquele no qual se expõe um tema, defendendo uma ideia central" (SÃO PAULO, 2009, $3^{\text {a }}$ série, Vol. 2, p. 21).

No texto didático, ressalta-se a necessidade da defesa de uma tese, organizada segundo a fórmula sintática sujeito + verbo + complementos ou predicativos, e o desenvolvimento de recursos argumentativos: definição e esclarecimento do sentido de palavras-chave, seleção e hierarquização de argumentos. O enfoque é dado aos aspectos formais, desconsiderando-se as condições reais de produção, circulação e recepção da dissertação escolar. Enfatiza-se a ficcionalização, uma vez que se toma por base uma tese inventada para apresentar ao professor o texto didático que explica o processo de construção do texto argumentativo: "Imaginemos a seguinte tese" (SÃO PAULO, 2009, $3^{\text {a }}$ série, Vol. 2, p. 22, grifo nosso).

$\mathrm{Na}$ última página do volume, apresentam-se três títulos de obras, relacionadas aos estudos da argumentação, como recursos de ampliação de conhecimentos do professor: $O$ texto argumentativo, Linguagem e persuasão, ambos de Adilson Citelli, e Tratado da argumentação: a Nova Retórica, de Chaïm Perelman e Lucie Olbrecht-Tyteca. Na Situação de Aprendizagem, não há qualquer menção a que se verifique a indicação de leitura no final do volume.

A "Atividade 3" consiste na apresentação de textos que possam embasar a elaboração do projeto de dissertação. Os mesmos textos utilizados no $C A$ são apresentados. Propõe-se a discussão dos textos em sala, seguida da elaboração em grupo do projeto de texto dissertativo, diferentemente do proposto no $C A$, que prevê a realização da atividade individualmente e a leitura do segundo texto em casa. 
No $C A$ e no $C P$, a oferta de textos que motivem a escrita da dissertação escolar, ainda em fase de planejamento, é escassa. No entanto, no $C P$, a interação entre os alunos e deles com o professor é mais valorizada. No $C A$, a discussão oral em sala sobre o tema da dissertação é embasada apenas na leitura e compreensão do poema $O$ açúcar, e a leitura do parágrafo do texto "O que é trabalho escravo" é realizada como tarefa de casa, seguida do planejamento da escrita, realizado individualmente. No $C P$, os dois textos são apresentados em aula, seguidos da discussão oral e da elaboração do projeto de texto em grupos, permitindo maior aproximação entre alunos e professor.

4.4 Análise D: "Momento de escrita: a redação de acesso ao ensino superior"

A Situação de Aprendizagem 4, "Momento de escrita: a redação de acesso ao ensino superior" (Vol. 2, 3a série EM), complementa o trabalho iniciado na Situação de Aprendizagem 2, na qual o aluno elabora o projeto de texto da dissertação escolar. Nessa situação, o aluno escreve a dissertação com base no projeto realizado anteriormente.

A Situação de Aprendizagem, composta por sete páginas, organiza-se em oito seções:

1) "Colhendo informações": compreensão da coletânea de textos para a escrita da dissertação escolar;

2) "Lição de casa": conectores argumentativos;

3) "Leitura e Análise de Texto": compreensão da coletânea de textos para a escrita da dissertação escolar;

4) "Lição de casa": conceito de senso comum;

5) "Preparando o caminho para o texto": elaboração de projeto de texto;

6) "Lição de casa": estrutura sintática da tese;

7) "Produzindo a dissertação escolar": escrita da dissertação escolar;

8) “Você aprendeu?": explicação sobre o que é argumentar. 


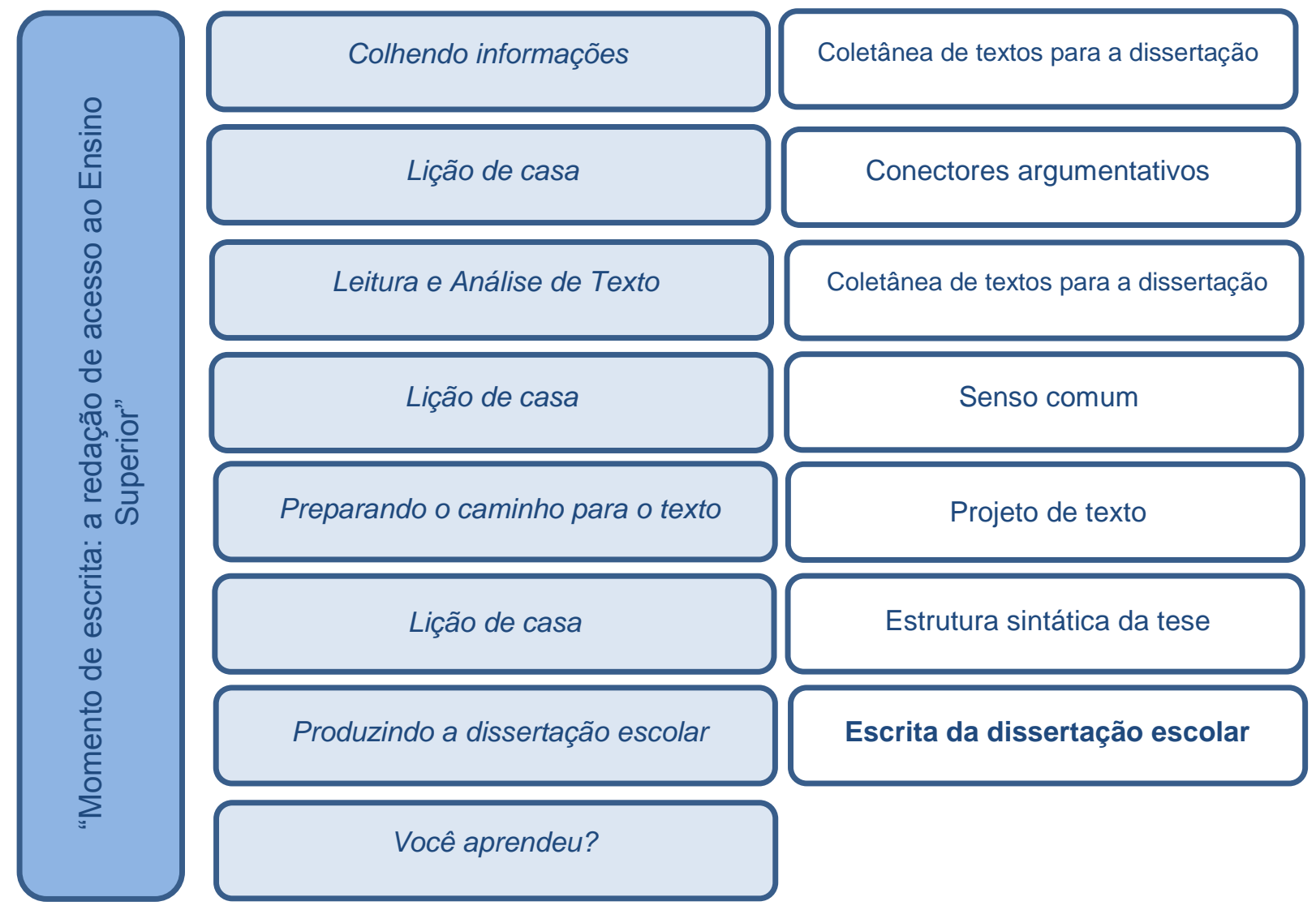

Esquema 5 - Seções didáticas e etapas de ensino na Situação de Aprendizagem "Momento de escrita: a redação de acesso ao Ensino Superior"

A primeira seção, "Colhendo informações", é composta por um quadro intitulado "Aprendendo a aprender" e três exercícios. No quadro, apresenta-se o gênero dissertação escolar como foco da Situação de Aprendizagem, definindo-o como "um gênero textual argumentativo, assim como o artigo de opinião e a resenha" (SÃO PAULO, 2010, 3ª série, Vol. 2, p.35).

Nos três exercícios seguintes, avalia-se a produção do projeto de texto, realizada na Situação de Aprendizagem 2, e analisa-se a primeira parte da coletânea de textos da proposta de redação do ENEM 2005. Essa informação não é dada ao aluno ou ao professor. Os quatro excertos presentes na proposta original são apresentados de maneira gradativa, entremeados por atividades de compreensão.

Nos exercícios dessa seção, o aluno comenta sobre as dificuldades encontradas na elaboração do projeto de texto, é questionado sobre a existência do 
problema do trabalho infantil no Brasil (tema da dissertação a ser escrita) e tem contato com o primeiro fragmento da proposta de redação do ENEM 2005.

A segunda seção, "Lição de casa", é composta por um exercício com três itens. Em cada um deles, o aluno deve ligar duas orações, utilizando um conectivo que expresse o sentido informado em cada item do exercício. $O$ aluno deve seguir o modelo de resposta dado no comando do exercício para escrever os períodos. Novamente, as relações de sentido se estabelecem no nível da frase, considerada fora de um contexto real, e a atividade se torna um exercício mecânico de seguimento de modelos.

Em "Leitura e Análise de Texto", seção seguinte, são apresentados os três fragmentos restantes da proposta de redação do ENEM 2005, por meio de quatro exercícios. A seção é iniciada por uma discussão oral, na qual se investiga a opinião do aluno a respeito da gravidade e das causas do trabalho infantil. Em seguida, o segundo fragmento da proposta de redação do ENEM 2005 é apresentado, seguido por dois exercícios. No primeiro, o aluno identifica informações explícitas no trecho lido e copia-as no caderno e, no segundo, discute com os colegas a adequação do ditado popular "O trabalho dignifica o homem" à realidade infantil.

Em seguida, há um quadro "Aprendendo a aprender", no qual discute-se o conceito de senso comum, definido como "conjunto de crenças consideradas verdadeiras em uma determinada sociedade, mesmo que não o sejam" (SÃO PAULO, 2010, 3a série, Vol. 2, p. 37). Além disso, chama-se a atenção do aluno para que ele evite sua ocorrência no texto argumentativo.

O terceiro fragmento da proposta de redação do ENEM 2005 é apresentado no terceiro exercício dessa seção, no qual se propõe que o aluno identifique um argumento considerado senso comum no fragmento lido. Em seguida, há uma segunda discussão oral, que introduz o último fragmento de texto a ser lido na coletânea, o artigo $4^{\circ}$ do Estatuto da Criança e do Adolescente, a partir da pergunta "Qual é a necessidade de termos leis?". Nesse fragmento, afirma-se o dever da família, da sociedade e do poder público de assegurar os direitos da criança e do adolescente, descritos no texto do artigo. A compreensão do artigo $4^{\circ}$ do Estatuto da Criança e do Adolescente é realizada no quarto exercício, com o questionamento sobre a observação desse artigo na comunidade em que o aluno vive. 
A finalização dessa seção consiste na proposta de uma terceira discussão oral, na qual o aluno é levado a identificar o tema central que permeia todos os textos.

$\mathrm{Na}$ quarta seção da Situação de Aprendizagem, uma segunda "Lição de casa", propõe-se que o aluno pesquise em jornais, revistas e no livro didático três frases que apresentem opiniões fundamentadas no senso comum e as analise, justificando sua escolha.

A quinta seção, "Planejando o caminho para o texto", é composta por dois exercícios. No primeiro, o aluno elabora o projeto de texto, seguindo as orientações apresentadas na Situação de Aprendizagem 2, que abordou a elaboração do projeto de texto, com acréscimo de dois itens: "exemplos que comprovem os argumentos" e " outras ideias que desejo aproveitar para o texto". No segundo exercício, propõe-se que o aluno responda a quinze questões, organizadas em cinco itens.

Os autores do ALP nomeiam os itens de organização da dissertação escolar de acordo com o parágrafo a que corresponde na composição formal do texto argumentativo: a) Primeiro parágrafo - introdução; b) Segundo parágrafo argumento mais fraco; c) Terceiro parágrafo - argumento intermediário; d) Quarto parágrafo - argumento mais forte; e) Último parágrafo - conclusão.

a) Primeiro parágrafo - introdução

- Do que vai tratar essa redação? (Que tese vai ser defendida?)

- Por que esse tema é importante?

b) Segundo parágrafo - argumento mais fraco

- Qual o argumento menos convincente de que disponho?

- Como ele se relaciona com o tema e a tese?

- Existe algum modo de exemplificar esse argumento? Qual?

c) Terceiro parágrafo - argumento intermediário

- Qual o argumento intermediário de que disponho?

- Como ele se relaciona com o tema e a tese?

- Existe algum modo de exemplificar esse argumento? Qual?

d) Quarto parágrafo - argumento mais forte

- Qual o argumento mais convincente de que disponho?

- Como ele se relaciona com o tema e a tese?

- Existe algum modo de exemplificar esse argumento? Qual?

- Que relações existem entre esse argumento e os dois anteriores?

e) Último parágrafo - conclusão

- Uma síntese de minhas ideias até o presente momento.

- Que solução proponho para esse problema do trabalho infantil?

- Como essa solução se relaciona com a realidade?

(SÃO PAULO, 2010, 3ª série, Vol. 2, p. 38-39) 
Na seção seguinte, há a proposta de uma terceira "Lição de Casa", na qual o aluno reescreve quatro orações dadas no $C A$ em ordem direta, sem alteração de sentido, com o objetivo de treinar a ordem sujeito-verbo-complementos ou predicativos.

A sétima seção, "Produzindo a dissertação escolar", é formada por quatro exercícios. No primeiro, propõe-se que o aluno escreva a dissertação de vestibular com base nas respostas dadas ao questionário do exercício anterior. No segundo exercício, o aluno deve trocar seu texto com um colega, antes da entrega ao professor, para obter sugestões de melhora. No terceiro exercício, propõe-se a revisão do texto com base nas contribuições de colegas e em critérios de avaliação fornecidos no $C A$, utilizados pelo professor na correção do texto. No quarto exercício, após a correção do professor, o aluno deve reescrever o texto e devolvêlo ao professor, para a segunda correção.

Observamos que a atividade prevê o resultado de um encaminhamento que privilegia o trabalho com a frase isolada: o "texto" torna-se uma somatória de orações, em que não há garantia do estabelecimento de relações de sentido entre as partes do texto. A dissertação escolar se torna sinônimo de agrupamentos de respostas, dadas com frases completas na ordem direta.

$\mathrm{Na}$ última seção, "Você aprendeu?", o aluno enumera os aspectos mais e menos interessantes da Situação de Aprendizagem e explica o que é argumentar.

No $C P$, a Situação de Aprendizagem se compõe da "Sondagem" e três atividades. Na "Sondagem", orienta-se o professor para que discuta com os alunos o tema trabalho infantil, foco da proposta de redação de vestibular apresentada nas atividades posteriores.

$\mathrm{Na}$ "Atividade 1", propõe-se o comentário sobre os projetos de texto entregues ao fim da Situação de Aprendizagem 2, com a sugestão de melhorias ao texto.

$\mathrm{Na}$ "Atividade 2", os quatro fragmentos da proposta de redação do ENEM 2005 são apresentados, sem indicação de exercícios de compreensão. Ao final da leitura dos quatro fragmentos, sugere-se ao professor que promova uma discussão em classe a respeito deles. Na discussão, o professor é orientado a questionar os alunos a respeito de três aspectos: 
- Qual o tema central, em comum, desses textos?

- Como eles apresentam contradições entre ideal e realidade?

- Como os textos demonstram que o problema não pode ficar reduzido ao senso comum?

(SÃO PAULO, 2009, 3aㅗ série, Vol. 2, p. 33)

Em seguida, um quadro intitulado "Para você, professor!" é fornecido, com a mesma definição de senso comum apresentada ao aluno no CA. Além disso, discute-se a apresentação de um argumento baseado no senso comum no terceiro fragmento da proposta de redação do ENEM 2005 e o caráter idealizador do quarto fragmento da mesma proposta de redação.

Ao final da discussão, é pedido ao professor que proponha a escrita de uma dissertação sobre o tema "O trabalho infantil na realidade brasileira". O comando da atividade proposta pede que os alunos considerem

\footnotetext{
"os conhecimentos adquiridos e as reflexões feitas ao longo de sua formação. Selecionem, organizem e relacionem argumentos, fatos e opiniões para defender seu ponto de vista e suas propostas, sem ferir os direitos humanos" (SÃO PAULO, 2009, $3^{\mathrm{a}}$ série, Vol. 2, p. 33).
}

$\mathrm{Na}$ "Atividade 3", orienta-se o professor que proponha aos alunos a elaboração de um projeto de texto, seguindo as mesmas orientações apresentadas no CA. Em um quadro com a indicação "Para você, professor!", os autores do ALP explicam a introdução de dois itens ao esquema de projeto de texto, apresentado na Situação de Aprendizagem 2: "Exemplo(s) que comprove(m) os argumentos" e "Outras ideias que desejo aproveitar para o texto". Segundo os autores do ALP, "o objetivo desses itens é que os alunos incorporem ao seu projeto elementos que possam depois aproveitar para a construção do texto dissertativo-argumentativo" (SÃO PAULO, 2009, 3ª série, Vol. 2, p. 34).

A "Atividade 4" consiste na proposta de escrita da dissertação e segue os mesmos procedimentos oferecidos no $C A$ : um roteiro com quinze questões, cujas respostas organizam-se na construção do texto dissertativo pedido. Há a preocupação de que o professor não aceite parágrafos compostos por uma única frase. No entanto, há a indicação do questionário como um modelo a ser seguido: "Acreditamos que este modelo poderá ser a base para outras possibilidades criativas 
de construção do texto argumentativo. Proponha que, para cada pergunta a seguir, o aluno faça uma frase" (SÃO PAULO, 2009, $3^{\mathrm{a}}$ série, Vol. 2, p. 35).

Verificamos que o seguimento de um roteiro de perguntas que embasa a "construção criativa" da dissertação é priorizado tanto no $C A$ quanto no $C P$. Não é oferecida uma dissertação escolar para a leitura e contato com o gênero em nenhum dos dois conjuntos de materiais. Os alunos devem escrever uma dissertação escolar sem nunca ter lido ao menos uma. Eles são motivados a transformar suas respostas ao questionário, dadas em uma frase, conforme pedido, em parágrafos; entretanto, não há orientações de como esse processo pode ser realizado. Não se apresenta uma redação de vestibular em cujos parágrafos sejam desenvolvidos os tópicos previstos na condução da proposta de escrita da dissertação escolar.

Realizado dessa maneira, como resposta mecânica a um questionário, acreditamos que o texto escrito pelo aluno não se apresenta como produto de reflexão, no qual estejam agregados "os conhecimentos adquiridos" ao longo da formação acadêmica, como pede o comando da atividade. $O$ resultado do percurso metodológico proposto ao aluno é um texto em que o posicionamento crítico diante dos fatos é nulo. 


\section{CONSIDERAÇÕES FINAIS}

Neste trabalho, nosso objetivo foi investigar o encaminhamento das propostas de redação de texto argumentativo dos gêneros resenha, artigo de opinião e dissertação escolar, retiradas de três volumes do apostilado de Língua Portuguesa que compõe o sistema de ensino adotado nas escolas públicas estaduais a partir de 2008. Na análise, identificamos e analisamos quatro Situações de Aprendizagem em torno do ensino do texto argumentativo e estabelecemos as relações entre três conjuntos de textos, elaborados pela Secretaria da Educação, no que se refere ao tratamento dado aos conteúdos apresentados: o Currículo de Língua Portuguesa, que prescreve os conteúdos e habilidades mínimas desenvolvidos em cada série; o Caderno do Professor, que fornece ao professor as orientações de como abordar os conteúdos e desenvolver as habilidades prescritas; e o Caderno do Aluno, que oferece ao aluno as atividades e propostas de lição de casa realizadas para a aquisição dos conceitos.

Para isso, apresentamos o contexto de criação do Programa São Paulo Faz Escola, responsável pela instituição do sistema apostilado de ensino nas escolas públicas estaduais, a partir da recuperação das condições sociais e históricas da utilização de apostilas como material didático. Surgidas no final da década de 1930 para utilização em cursos profissionalizantes, as apostilas tornaram-se material obrigatório em cursos pré-vestibulares nas décadas seguintes e atingiram as escolas particulares e públicas a partir da década de 1990. Desde seu surgimento, apresentaram como característica marcante a abordagem sintética dos conteúdos, na qual a reflexão e a construção do conhecimento não são prioridades. 
$\mathrm{Na}$ rede estadual, o sistema apostilado de ensino se constituiu de dois conjuntos de apostilas, os Cadernos do Professor (CP) e os Cadernos do Aluno $(C A)$, que passaram a ser utilizados em épocas diferentes. Em 2008, os professores receberam os $\mathrm{CP}$, com as atividades e orientações de como desenvolvê-las com os alunos, e a Proposta Curricular do Estado de São Paulo, um referencial curricular apresentando os conteúdos e habilidades esperados em cada série. No ano seguinte, os alunos receberam os CA, com as propostas de atividades a serem desenvolvidas em aula e em casa. Somente em 2010, após a consolidação da Proposta, o Currículo do Estado de São Paulo, com os conteúdos prescritos, foi entregue aos professores. Não houve modificações substanciais em nenhum dos conjuntos de apostilados elaborados anteriormente, mesmo depois da publicação do Currículo de Língua Portuguesa (CLP) em 2010, o que motivou uma de nossas questões de investigação: como se relacionam os dois conjuntos de apostilados e o documento oficial curricular?

Para responder a essa pergunta, foi necessário aprofundar o conceito de texto segundo a concepção teórica de Bakhtin e o Círculo. Considerar os dois conjuntos de materiais didáticos e o CLP como textos significa instaurá-los como enunciados com autor e destinatário específicos, produzidos em situação social, histórica e cultural determinadas, dotados de posicionamentos ideológicos que refletem e refratam o meio social em que estão inseridos. Nesse sentido, os três conjuntos de textos dialogam entre si, havendo concordâncias, discordâncias, refutações e confrontos.

A necessidade de delimitação de um objeto de análise levou-nos à escolha de quatro atividades didáticas em que o ensino do texto argumentativo e a proposta de escrita do texto no gênero abordado ocorriam pela primeira vez no material didático direcionado ao Ensino Médio. A escolha por analisar o ensino do texto argumentativo deveu-se à relevância dada à aprendizagem da escrita argumentativa, verificada tanto nos referenciais curriculares nacionais e no CLP quanto na avaliação SARESP, que avalia o desempenho acadêmico dos alunos da rede estadual. Selecionamos as Situações de Aprendizagem em que ocorre o ensino de resenha na $1^{\underline{a}}$ série do Ensino Médio, de artigo de opinião na $2^{a}$ série e de dissertação escolar na $3^{\text {a }}$ série. 
A análise mostrou que há tensão entre a prescrição instituída no $C L P$ e a efetivação das atividades nos $C P$ e nos $C A$. De acordo com o $C L P$, a aquisição e o desenvolvimento de conteúdos e habilidades mínimas relacionadas ao domínio da escrita argumentativa devem levar o aluno a construir e expressar uma postura crítica e ativa diante dos textos com os quais toma contato. Para isso, deve-se trabalhar com textos reais, de efetiva circulação na sociedade, que possam oferecer as condições necessárias para que a criticidade seja construída.

Nos $C P$ e nos $C A$, entretanto, o encaminhamento das atividades conduz para resultados diferentes. Três elementos nortearam a análise dos $C A$, contrapostos aos $C P$ : a oferta de textos do gênero abordado para leitura e compreensão, a fundamentação teórica apresentada a professores e/ou alunos e a abordagem da proposta de escrita do texto argumentativo abordado.

Nas quatro Situações de Aprendizagem analisadas, verificamos a apresentação de um único texto integral, nem sempre de efetiva circulação social, o que pouco contribuiu para o embate de vozes necessário à construção da argumentação. O contato com uma quantidade maior de textos é fundamental para que o aluno possa perceber as regularidades do gênero trabalhado, respeitando-se as singularidades próprias de cada texto. A oferta de um único exemplo leva à padronização do texto, que passa a ser seguido como modelo.

A fundamentação teórica oferecida a alunos e professores consistiu na apresentação de textos didáticos elaborados pelos autores do material didático, sem referências bibliográficas completas que indicassem as fontes consultadas. Aos professores, quatro indicações de obras relacionadas aos estudos de argumentação são fornecidas na última página de três volumes dos $C P$, um da $2^{a}$ série e os demais, da 3aㅗ séries, como recursos de ampliação de conhecimentos, sem ligação direta às Situações de Aprendizagem que enfocam o ensino do texto argumentativo. Nenhuma das indicações de obras teóricas consta das referências apresentadas no CLP.

A produção de texto foi realizada como um roteiro de atividades a serem seguidas pelo aluno, enfatizando a realização de tarefas. Na maioria das situações analisadas, o contato com a teoria apresentada no material didático ou as propostas de escrita do texto foram realizadas como tarefa de casa, sem a intervenção do 
professor ou a interação com os outros alunos. Em todas as propostas de escrita de texto argumentativo, a ausência de discussão consistente do tema abordado foi marcante e a efetivação da proposta tornou-se um exercício mecânico de seguimento de modelos dados anteriormente, na qual o aluno não se coloca como autor, mas como reprodutor de textos.

O texto argumentativo, visto como um fim em si mesmo, é ensinado como sendo o resultado da realização de etapas sucessivas, nas quais se prioriza o enfoque metodológico, observado na interação realizada com alunos e professores, em que a preferência pelo uso dos verbos no imperativo afirmativo evidencia o seguimento de tarefas. De acordo com Campos (2012, p.251):

\footnotetext{
Esse [o texto] não compõe uma unidade estanque, mas é entendido como um elo na comunicação discursiva, pois é orientado pelos elementos que o antecedem e relacionado com os outros que convoca de maneira tensa e constante.
}

Para que a produção do aluno se torne um texto de fato, é necessário que ele seja um elo na cadeia comunicativa, o que significa dizer que, no processo de ensino e aprendizagem do texto argumentativo, o aluno precisa ter contato com outros textos do mesmo gênero, considerando as condições reais de produção, circulação e recepção do texto.

Os resultados mostram que a hipótese inicial apresentada no trabalho não se confirma, na medida em que não há concordância total entre a prescrição do CLP e as propostas de trabalho apresentadas no $C P$ e no $C A$, no que se refere ao conceito de texto e ao desenvolvimento das habilidades de leitura e escrita de textos argumentativos.

Embora represente um avanço na educação paulista, no sentido de oferecer uma grade curricular padronizada a todos os alunos da rede, o sistema apostilado de ensino adotado é limitado no que se refere à construção da criticidade, requisito necessário e esperado à constituição do aluno como sujeito ativo e cidadão.

Essa limitação pode estar relacionada ao fato de que não fica claro aos professores como desenvolver as habilidades leitoras e escritoras exigidas no CLP 
durante as aulas de português, uma vez que a abordagem dos conteúdos específicos, referentes ao eixo linguístico-discursivo, é tênue.

A análise do encaminhamento das propostas de escrita de textos argumentativos nas Situações de Aprendizagem do CA mostra claros indícios de que a prática dos gêneros no apostilado de Língua Portuguesa retoma práticas já existentes na tradição escolar. Essa retomada consiste, precisamente, em uma mescla do ensino de produção de texto e da gramática, muitas vezes de forma bifurcada, na escolha de objetos de ensino fixos e fluidos.

A reapresentação de aspectos sintáticos pertinentes à escrita de textos argumentativos, como a abordagem dos conectores argumentativos e da construção sintática da tese, na seção Lição de casa, leva a supor que o aluno já domina esse conteúdo de forma integrada ao texto. A sequência apresentada, no entanto, não articula esse conhecimento ao texto, levando a um distanciamento entre a produção escrita de textos argumentativos e a sintaxe.

Percebemos que as sugestões para o professor e para o aluno emolduram a proposta de redação de modo única e exclusivamente didático, e não atingem o objetivo proposto pelo CLP, que é o de levar o aluno a se posicionar de maneira crítica e cidadã por meio de textos.

Esperamos que esse trabalho motive novas investigações sobre o apostilado de Língua Portuguesa utilizado na rede estadual de ensino, de maneira que esse material possa ganhar novas considerações. 


\section{Referências}

ADRIÃO, Theresa et al. Uma modalidade peculiar de privatização da educação pública: a aquisição de "sistemas de ensino" por municípios paulistas. Educação \& Sociedade, v. 30, p. 799-818, 2009. Disponível em: <http://www.scielo.br/pdf/es/v30n108/a0930108.pdf>. Acesso em: 30 ago. 2012.

ANDRADE SILVA, Valéria. A apropriação da Proposta Curricular do programa "São Paulo faz escola" pelos professores de Língua Portuguesa. Dissertação (Mestrado). Universidade Nove de Julho - UNINOVE, São Paulo, 2010.

ANGENOT, Marc. Novas proposições para o estudo da argumentação na vida social. (Trad. Maria Helena Cruz Pistori). EID\&A - Revista Eletrônica de Estudos Integrados em Discurso e Argumentação, llhéus, n.3, p. 142-155, nov. 2012. Disponível em: < http://www.uesc.br/revistas/eidea/revistas/revista3/eidea3-11.pdf>. Acesso em 07 jan. 2013.

ANJOS, Arlete Alves dos. Sentidos-e-significados de diferentes áreas sobre a Proposta Curricular e os Cadernos da SEE/SP. Dissertação (Mestrado). Programa de Pós-Graduação em Linguística Aplicada e Estudos da Linguagem, Pontifícia Universidade Católica de São Paulo, São Paulo, 2010.

ARISTÓTELES. Retórica (Trad. Manuel Alexandre Júnior). Lisboa: Imprensa Nacional - Casa da Moeda, 2005.

BAKHTIN, Mikhail. O problema do texto na linguística, na filologia e em outras ciências humanas: uma experiência de análise filosófica (1959-61). In: Estética da criação verbal. Trad. Paulo Bezerra. 4. ed. São Paulo: Martins Fontes, 2003, p. 307336.

Os gêneros do discurso (1952-53). In: Estética da criação verbal. Trad. Paulo Bezerra. 4.ed. São Paulo: Martins Fontes, 2003, p. 261-306.

BAKHTIN, Mikhail (VOLOCHÍNOV, Valentin) Marxismo e Filosofia da Linguagem. Problemas fundamentais do Método Sociológico na Ciência da Linguagem. Trad. Michel Lauand; Yara F. Vieira. 11.ed. São Paulo: Hucitec, 2004[1929].

BARBOSA, Jacqueline P. Sequência didática: artigo de opinião. São Paulo: Secretaria de Estado da Educação de São Paulo, s/d.

BARRICELLI, Ermelinda. Transformações e conflitos no processo de elaboração, de difusão e de utilização de instruções oficiais de educação infantil: um estudo genealógico. Tese (Doutorado). Programa de Pós-Graduação em Linguística Aplicada e Estudos da Linguagem, Pontifícia Universidade Católica de São Paulo, São Paulo, 2012.

BEZERRA, Egle Pessoa. Parceria público-privada nos municípios de Brotas e Pirassununga: estratégias para a oferta do ensino? 2008. Dissertação (Mestrado). Instituto de Biociências, Universidade Estadual Paulista, Rio Claro. 
BRÄKLING, Kátia Lomba. Trabalhando com artigo de opinião: re-visitando o eu no exercício da (re)significação da palavra do outro. In: ROJO, Roxane (org.) A prática de linguagem em sala de aula: praticando os PCNs. São Paulo: Mercado de Letras, 2000, p. 221-246.

BRASIL. Sinopse Estatística da Educação Básica 2011. MEC/Inep: Brasília, 2012. Disponível em: <http://portal.inep.gov.br/basica-censo-escolar-sinopse-sinopse>. Acesso em: 30 ago. 2012.

Matriz de Referência ENEM. MEC/Inep: Brasília, 2012. Disponível em: <http://download.inep.gov.br/educacao_basica/enem/downloads/2012/matriz_referen cia_enem.pdf>. Acesso em: 15 jan.2013.

Disponível

A redação no ENEM 2012: guia do participante. MEC/Inep: Brasília, 2012. <http://download inep gov br/educacao basica/enem/downloads/2012/guia participa nte_redacao_enem2012.pdf>. Acesso em: 15 jan. 2013.

Ministério da Educação e Desporto. Conselho Nacional da Educação. Câmara de Educação Básica. Resolução n. 3 de 26/6/98. Disponível em: $<$ http://portal.mec.gov.br/cne/arquivos/pdf/rceb03_98.pdf>. Acesso em: 22 nov. 2012.

. Parâmetros Curriculares Nacionais (Ensino Médio). Volume 1: Linguagens, Códigos e suas Tecnologias. Ministério da Educação: Brasília, 2000.

Orientações Complementares aos Parâmetros Curriculares Nacionais. Linguagens, Códigos e suas Tecnologias. Ministério da Educação: Brasília, 2002.

Orientações Curriculares para o Ensino Médio. Volume 1: Linguagens, Códigos e suas Tecnologias. Ministério da Educação, Secretaria de Educação Básica: Brasília, 2006.

BRITTO, Tatiana Feitosa de. O livro didático, o mercado editorial e os sistemas de ensino apostilados. Centro de Estudos da Consultoria do Senado, 2011. Disponível em: <http:// www.senado.gov.br/senado/conleg/textos_discussao/TD92TatianaFeitosadeBritto.pdf>. Acesso em 30 ago. 2012.

BUNZEN, C. Reapresentação de objetos de ensino em livros didáticos de língua portuguesa: um estudo exploratório. In: SIGNORINI, I. (Org.) Significados da inovação no ensino de língua portuguesa e na formação de professores. Campinas: Mercado de Letras, 2007, p. 79-108.

CAMPOS, Maria Inês Batista. A questão da arquitetônica em Bakhtin: um olhar para os materiais didáticos de língua portuguesa. In: Filologia e Linguística portuguesa, N. 14(2), 2012, p.247-263.

. A construção da identidade nacional nas crônicas da Revista do Brasil. São Paulo: Olho d'Água/Fapesp, 2011a. 
Textos argumentativos em materiais didáticos: que proposta seguir? In: Delta: Documentação de Estudos em Linguística Teórica e Aplicada, Vol. 27, N. 2, 2011b, p. 219-234.

CÁRIA, Neide Pena; ANDRADE, Nelson Lambert de. Material didático sob a lógica do mercado: uma questão de política educacional. In: Políticas Públicas e Gestão da Educação: construção histórica, debates contemporâneos e perspectivas futuras: programa e trabalhos completos / XXV Simpósio Brasileiro de Política e Administração da Educação, II Congresso Ibero Americano de Política e Administração da Educação; organizador: Benno Sander - Niterói (RJ): ANPAE; São Paulo (SP): PUCSP/FACED/PPGE, 2011. 1 CD-ROM. (Coleção Biblioteca ANPAE, Série Cadernos: $\quad$ n. 11). Disponível em: <http://www.anpae.org.br/simposio2011/cdrom2011/PDFs/trabalhosCompletos/comu nicacoesRelatos/0419.pdf>. Acesso em: 02 nov. 2012.

CARVALHO, Bruna; COSTA, Áurea de Carvalho. Sistema de ensino apostilado na rede pública municipal. In: XXI Congresso de Iniciação Científica da UNESP, 2009. São José do Rio Preto: Universidade Estadual Paulista, p. 1-4. Disponível em: <http://prope.unesp.br/xxi_cic/27_36916343893.pdf>. Acesso em: 02 nov. 2012.

CARVALHO NETO, Cassiano Zeferino. O apostilismo. In: ___. E agora, professor? Por uma pedagogia vivencial. São Paulo: Instituto para a Formação Continuada em Educação (IFCE), 2004. Disponível em: <http://ifce.com.br/php/artigo_mostra.php?cod=22>. Acesso em: 27 mar. 2013.

CITELLI, Adilson. Linguagem e persuasão. São Paulo: Ática, 1988.

O texto argumentativo. São Paulo: Scipione, 1994.

CUNHA, Ana Maria Affonso. Representações de uma comunidade escolar sobre o trabalho do professor de inglês: prescrição e reflexão. Tese (Doutorado). Programa de Pós-Graduação em Linguística Aplicada e Estudos da Linguagem, Pontifícia Universidade Católica de São Paulo, São Paulo, 2008.

CUNHA, Luiz Antônio. Contribuição para a análise das interferências mercadológicas nos currículos escolares. Revista Brasileira de Educação, Rio de Janeiro, v. 16, n. 48, dez. $2011 . \quad$ Disponível em: <http://www.scielo.br/scielo.php?script=sci_arttext\&pid=S1413-

$24782011000300004 \&$ lng=en\&nrm=iso >. Acesso em: 02 nov. 2012.

CUSTÓDIO, Cristine Leonardo. Gêneros do discurso e ensino de Língua Portuguesa: a leitura da proposta curricular do estado de São Paulo por uma professora de Língua Portuguesa. Dissertação (Mestrado). Universidade Estadual Paulista, Instituto de Biociências, Rio Claro, 2010.

FIAMENGUI, Gustavo. Impactos do Projeto São Paulo Faz Escola no trabalho do professor. Dissertação (Mestrado). Programa de Pós-graduação em Educação da Universidade Católica de Santos, São Paulo, 2009. 
IZIDORO, Solange. O ensino de Língua Portuguesa: um olhar sobre a leitura. Dissertação (Mestrado). Pontifícia Universidade Católica de São Paulo, São Paulo, 2010.

LEITE, Gisele Guimarães Belluomini. Leitura crítica da metodologia de ensino inserida na proposta curricular de língua portuguesa do estado de São Paulo (5 $5^{\underline{a}}$ série 2008/2009). Dissertação (Mestrado). Universidade do Oeste Paulista UNOESTE, Presidente Prudente, 2010.

LELLIS, Marcelo. Sistemas de ensino versus livros didáticos: várias faces de um enfrentamento. In: Simpósio nacional do livro didático, Educação e História, 2007. São Paulo, Universidade de São Paulo, p.1000-1012. 1 CD-ROM. Disponível em: <http://www.abrale.com.br/wp-content/uploads/sistemas-ensino-livros-didaticos.pdf>. Acesso em: 02 nov. 2012

LOUSADA, Eliane Gouvêa. Entre trabalho prescrito e realizado: um espaço para a emergência do trabalho real do professor. Tese (Doutorado). Programa de PósGraduação em Linguística Aplicada e Estudos da Linguagem, Pontifícia Universidade Católica de São Paulo, São Paulo, 2006.

MACHADO, Anna Rachel. A organização sequencial da resenha crítica. The ESPecialist. Vol.17, N. 2, 1996, p. 133-149.

MARCUSCHI, Luís Antônio. Gêneros textuais: definição e funcionalidade. In: DIONISIO, Ângela Paiva et al (org.) Gêneros textuais \& ensino. Rio de Janeiro: Lucerna, 2002, p.19-36.

MARTINS, Carlos Benedito. A reforma universitária de 1968 e a abertura para o ensino superior privado no Brasil. Educação \& Sociedade, Campinas, vol.30, n. 106, p.15-35, jan./abr. 2009.2 Disponível em: <http://www.scielo.br/pdf/es/v30n106/v30n106a02>. Acesso em: 02 nov. 2012.

MEDVIÉDEV, Pável Nikoláievich. O método formal nos estudos literários: introdução crítica a uma poética sociológica. Trad. Sheila Camargo Grillo; Ekaterina Vólkova Américo. São Paulo: Contexto, 2012[1928].

MINOZZI JR., Essio. A educação brasileira na Era Vargas. Anais IV Colóquio de pesquisa sobre Instituições Escolares: as instituições escolares da Metrópole / Carlos Bauer (org.)...[ et. al] São Paulo: UNINOVE, 2007. Disponível em: <http://www.uninove.br/PDFs/Mestrados/Educa\%C3\%A7\%C3\%A3o/Anais_IV_coloq uio/COMUNICA\%C3\%87\%C3\%830\%2017.pdf>. Acesso em: 02 nov. $201 \overline{2}$.

MOTTA, Carlos Eduardo de Souza. Indústria cultural e o sistema apostilado: a lógica do capitalismo. Cadernos Cedes, v. 21, n. 54, p. 82-89, ago. 2001. Disponível em: <http://www.scielo.br/pdf/\%0D/ccedes/v21n54/5272.pdf>. Acesso em: 30 ago. 2012.

NASCIMENTO, Gisele Alves. Os modelos de letramento subjacentes em uma nova proposta oficial de ensino de língua materna: novas ideias, novos rumos? Dissertação (Mestrado). Universidade Estadual de Campinas, Instituto de Estudos da Linguagem, Campinas, 2010. 
NETTO, Adolpho Ribeiro. O vestibular ao longo do tempo: implicações e implicâncias. Trabalho apresentado no Seminário sobre "Vestibular Hoje", MEC/SESU/CAPES, Brasília, p. 41-48, 1985. Disponível em: <http://www.fcc.org.br/pesquisa/publicacoes/es/artigos/116.pdf>. Acesso em: 02 nov. 2012.

NICOLETI, João Ernesto. Ensino apostilado na escola pública: tendência crescente nos municípios da região de São José do Rio Preto - SP. Dissertação (Mestrado). Faculdade de Ciências e Letras, Universidade Estadual Paulista, Araraquara, 2009.

PERELMAN, Chaïm, OLBRECHTS-TYTECA, Lucie. Tratado da argumentação: a nova retórica. Trad. Maria Ermantina de Almeida Prado Galvão. 2.ed. São Paulo: Martins Fontes, 2005.

PORTELA, Sonia Cristina. A imagem discursiva do trabalho educacional nos prescritos oficiais. Dissertação (Mestrado). Programa de Pós-Graduação em Linguística Aplicada e Estudos da Linguagem, Pontifícia Universidade Católica de São Paulo, São Paulo, 2006.

REBOUL, Olivier. Introdução à retórica. Trad. Ivone Castilho Benedetti. 2.ed. São Paulo: Martins Fontes, 2004.

ROSSI, Murilo. A nova proposta curricular do ensino de Geografia na rede estadual de São Paulo: um estudo. Dissertação (Mestrado). Programa de Pós-Graduação em Geografia Humana. Faculdade de Filosofia, Letras e Ciências Humanas, Universidade de São Paulo, São Paulo, 2011.

SÃO PAULO. Programa de Qualidade da Escola: nota técnica. São Paulo: SEE, 2012. Disponível em: <http://idesp.edunet.sp.gov.br/>. Acesso em: 30 ago. 2012.

Disponível

SARESP 2011: resultados gerais da rede estadual. São Paulo: SEE, 2012.

<http://saresp.fde.sp.gov.br/2011/pdf/Resultados\%20gerais\%20da\%20Rede\%20Est adual.pdf>. Acesso em: 30 ago. 2012.

. SARESP 2010: sumário executivo. São Paulo: SEE, 2011. Disponível em: <http://saresp.fde.sp.gov.br/2010/Pdf/Sum\%C3\%A1rio_Executivo_2010.pdf>. Acesso em: 30 ago. 2012.

. Currículo do Estado de São Paulo: Linguagens, códigos e suas tecnologias. Coordenação geral: Maria Inês Fini, coordenação de área: Alice Vieira. São Paulo: SEE, 2010.

- Caderno do Aluno: língua portuguesa, ensino médio - 1ํㅡ série, volume 2. Coordenação geral: Maria Inês Fini, coordenação de área: Alice Vieira. 2.ed. São Paulo: SEE, 2010. 
Caderno do Aluno: língua portuguesa, ensino médio - $1^{\underline{a}}$ série, volume 3. Coordenação geral: Maria Inês Fini, coordenação de área: Alice Vieira. 2.ed. São Paulo: SEE, 2010.

. Caderno do Aluno: língua portuguesa, ensino médio - 1a série, volume 4. Coordenação geral: Maria Inês Fini, coordenação de área: Alice Vieira. 2.ed. São Paulo: SEE, 2010.

. Caderno do Aluno: língua portuguesa, ensino médio - 2ª série, volume 1. Coordenação geral: Maria Inês Fini, coordenação de área: Alice Vieira. 2.ed. São Paulo: SEE, 2010.

. Caderno do Aluno: língua portuguesa, ensino médio - $2^{\mathrm{a}}$ série, volume 2. Coordenação geral: Maria Inês Fini, coordenação de área: Alice Vieira. 2.ed. São Paulo: SEE, 2010.

. Caderno do Aluno: língua portuguesa, ensino médio - $2^{\mathrm{a}}$ série, volume 3. Coordenação geral: Maria Inês Fini, coordenação de área: Alice Vieira. 2.ed. São Paulo: SEE, 2010.

. Caderno do Aluno: língua portuguesa, ensino médio - $2^{\mathrm{a}}$ série, volume 4. Coordenação geral: Maria Inês Fini, coordenação de área: Alice Vieira. 2.ed. São Paulo: SEE, 2010.

. Caderno do Aluno: língua portuguesa, ensino médio - $3^{a}$ série, volume 1. Coordenação geral: Maria Inês Fini, coordenação de área: Alice Vieira. 2.ed. São Paulo: SEE, 2010.

. Caderno do Aluno: língua portuguesa, ensino médio - $3^{a}$ série, volume 2. Coordenação geral: Maria Inês Fini, coordenação de área: Alice Vieira. 2.ed. São Paulo: SEE, 2010.

. Caderno do Aluno: língua portuguesa, ensino médio - $3^{\mathrm{a}}$ série, volume 3. Coordenação geral: Maria Inês Fini, coordenação de área: Alice Vieira. 2.ed. São Paulo: SEE, 2010.

. Caderno do Aluno: língua portuguesa, ensino médio - $3^{a}$ série, volume 4. Coordenação geral: Maria Inês Fini, coordenação de área: Alice Vieira. 2.ed. São Paulo: SEE, 2010.

. Caderno do Professor: língua portuguesa, ensino médio - $1^{\text {a }}$ série, volume 1. Coordenação geral: Maria Inês Fini, coordenação de área: Alice Vieira. 2.ed. São Paulo: SEE, 2009.

. Caderno do Professor: língua portuguesa, ensino médio - $1^{\text {a }}$ série, volume 2. Coordenação geral: Maria Inês Fini, coordenação de área: Alice Vieira. 2.ed. São Paulo: SEE, 2009. 
. Caderno do Professor: língua portuguesa, ensino médio - $1^{\text {a }}$ série, volume 3. Coordenação geral: Maria Inês Fini, coordenação de área: Alice Vieira. 2.ed. São Paulo: SEE, 2009.

. Caderno do Professor: língua portuguesa, ensino médio - $1^{\text {a }}$ série, volume 4. Coordenação geral: Maria Inês Fini, coordenação de área: Alice Vieira. 2.ed. São Paulo: SEE, 2009.

- Caderno do Professor: língua portuguesa, ensino médio - $2^{a}$ série, volume 1. Coordenação geral: Maria Inês Fini, coordenação de área: Alice Vieira. 2.ed. São Paulo: SEE, 2009.

- Caderno do Professor: língua portuguesa, ensino médio - $2^{\mathrm{a}}$ série, volume 2. Coordenação geral: Maria Inês Fini, coordenação de área: Alice Vieira. 2.ed. São Paulo: SEE, 2009.

. Caderno do Professor: língua portuguesa, ensino médio - $2^{\mathrm{a}}$ série, volume 3. Coordenação geral: Maria Inês Fini, coordenação de área: Alice Vieira. 2.ed. São Paulo: SEE, 2009.

. Caderno do Professor: língua portuguesa, ensino médio - $2^{\mathrm{a}}$ série, volume 4. Coordenação geral: Maria Inês Fini, coordenação de área: Alice Vieira. 2.ed. São Paulo: SEE, 2009.

. Caderno do Professor: língua portuguesa, ensino médio - $3^{\underline{a}}$ série, volume 1. Coordenação geral: Maria Inês Fini, coordenação de área: Alice Vieira. 2.ed. São Paulo: SEE, 2009.

. Caderno do Professor: língua portuguesa, ensino médio - $3^{\text {a }}$ série, volume 2. Coordenação geral: Maria Inês Fini, coordenação de área: Alice Vieira. 2.ed. São Paulo: SEE, 2009.

- Caderno do Professor: língua portuguesa, ensino médio - $3^{a}$ série, volume 3. Coordenação geral: Maria Inês Fini, coordenação de área: Alice Vieira. 2.ed. São Paulo: SEE, 2009.

. Caderno do Professor: língua portuguesa, ensino médio - $3^{\underline{a}}$ série, volume 4. Coordenação geral: Maria Inês Fini, coordenação de área: Alice Vieira. 2.ed. São Paulo: SEE, 2009.

. SARESP 2009: sumário executivo. São Paulo: SEE, 2010. Disponível em: <http://saresp.fde.sp.gov.br/2009/ArquivosPdf/SUMARIO_SARESP\%202009_Final_ 17_06.pdf>. Acesso em: 30 ago. 2012.

. SARESP 2008: sumário executivo. São Paulo: SEE, 2009. Disponível em: <http://saresp.fde.sp.gov.br/2008/pdf/Sumario_Executivo_2008_completo.pdf>. Acesso em: 30 ago.2012. 
. SARESP 2007: sumário executivo. São Paulo: SEE, 2008. Disponível em: <http://saresp.fde.sp.gov.br/2007/Arquivos/Boletim_Conteudo/Sum\%C3\%A1rio\%20e xecutivo.pdf>. Acesso em: 30 ago. 2012.

SOUZA, Edna. Dissertação: gênero ou tipo textual? In: DIONISIO, A.P. \& BESERRA, N. S. (orgs.) Tecendo textos, construindo experiências. 2.ed. Rio de Janeiro: Lucerna, 2003. p. 163-183.

SOUZA-E-SILVA, Maria Cecília. O ensino como trabalho. In: MACHADO, A.R. (org.) O ensino como trabalho: uma abordagem discursiva. Londrina: Editora da Universidade Estadual de Londrina, 2004.

Sistemas de ensino: produção discursiva de sentidos sobre a educação e o trabalho do professor. In: BARBISAN, L.; FANTI, M. G. (orgs.) Enunciação e discurso: tramas de sentidos. São Paulo: Contexto, 2012, p. 116-130.

VIALLI, Andrea. Quase metade das cidades paulistas usa apostila nas escolas municipais. O Estado de S. Paulo. Caderno Notícias. 21 jul. 2011. Disponível em: <http://www.estadao.com.br/noticias/impresso,quase-metade-das-cidades-paulistasusa-apostila-nas-escolas-municipais,747606,0.htm>. Acesso em: 02 nov. 2012.

VILELA, Mário; KOCH, Ingedore Villaça. Gramática da Língua Portuguesa: gramática da palavra, gramática da frase, gramática do texto/discurso. Coimbra: Almedina, 2001, p.545-547.

VOLOCHÍNOV, Valentin (BAKHTIN, Mikhail) A palavra na vida e na poesia. Introdução ao problema da poética sociológica (1926). In: VOLOCHÍNOV, Valentin; BAKHTIN, Mikhail. Palavra própria e palavra outra na sintaxe da enunciação. São Carlos: Pedro \& João Editores, 2011, p. 145-181.

WHITAKER, Dulce Consuelo Andreatta. Da "invenção" do vestibular aos cursinhos populares: um desafio para a Orientação Profissional. Revista Brasileira de Orientação Profissional. São Paulo, v. 11, n. 2, jul-dez. 2010, p. 289297. Disponível

em: $<$ http://pepsic.bvsalud.org/scielo.php?script=sci_arttext\&pid=S167933902010000200013\&lng=pt\&nrm=iso>. Acesso em: 02 nov. 2012.

ZOTTI, Solange Aparecida. O ensino secundário nas reformas Francisco Campos e Gustavo Capanema: um olhar sobre a organização do currículo escolar. Anais do IV Congresso Brasileiro de História da Educação. Goiânia: Universidade Católica de Goiás / SBHE, 2006. Disponível em: $<$ http://www.sbhe.org.br/novo/congressos/cbhe4/individuaiscoautorais/eixo01/Solange\%20Aparecida\%20Zotti\%20-\%20Texto.pdf>. Acesso em: 02 nov. 2012. 
ANEXOS (EM CD) 
ANEXO A - "As vozes do outro e a nossa na resenha" (Caderno do Aluno, Vol. 3, 1a série $\mathrm{EM})$

ANEXO B - "O que faz de alguém um escritor?" (CA, Vol. 1, 2ª série $\mathrm{EM})$

ANEXO C - "Elaborando um projeto de dissertação" (CA, Vol. 2, 3ª série EM)

ANEXO D - "Momento de escrita: a redação de acesso ao ensino superior" ( $C A$, Vol. 2, 3aㅗ série $\mathrm{EM})$

ANEXO E - "As vozes do outro e a nossa na resenha" (Caderno do Professor, Vol. 3, $1^{\text {a }}$ série EM)

ANEXO F - "O que faz de alguém um escritor?" ( $C P$, Vol. 1, 2ª série $E M)$

ANEXO G - "Elaborando um projeto de dissertação" (CP, Vol. 2, 3ª série EM)

ANEXO H - "Momento de escrita: a redação de acesso ao ensino superior" ( $C A$, Vol. 2, 3ํㅗㄹ série EM)

ANEXO I - Currículo de Língua Portuguesa

ANEXO J - Quadro de conteúdos e habilidades em Língua Portuguesa - 1ª série EM (Currículo de Língua Portuguesa)

ANEXO K - Quadro de conteúdos e habilidades em Língua Portuguesa - $2^{\mathrm{a}}$ série $\operatorname{EM}(C L P)$

ANEXO L - Quadro de conteúdos e habilidades em Língua Portuguesa - 3ª série $\operatorname{EM}(C L P)$ 


\section{ANEXO A - "As vozes do outro e a nossa na resenha" (Caderno do Aluno, Vol. 3, 1ㄹ série $E M)$}

\section{SITUAÇÃO DE APRENDIZAGEM 4 AS VOZES DO OUTRO E A NOSSA NA RESENHA}

Após trabalhar com uma instalação, nesta Situação de Aprendizagem você participará do processo de construçáo de uma resenha, texto que apresenta um olhar específico dentro de uma determinada situaçăo.

1. Discutam, em classe e sob a orientaçăo do professor, as impressốes de todos sobre a exposiçáo.

\section{Leitura e Análise de Texto}

1. Você vai ler um texto do crítico Lauro Lisboa Garcia sobre a apresentaçáo da cantora Marcia Castro. Ao terminar de ler a resenha, você será capaz de responder à questão:

- Por que o autor do texto recomenda o show de Marcia Castro?

\section{Marcia Castro combina arte e boa diversáo}

Cantora ganha a plateia pela inteligência mesmo com repertório pouco conhecido

Crítica: Lauro Lisboa Garcia

Marcia Castro já deixou claro no álbum de estreia, Pecadinho, que se faz de porta-voz da irreverência. Não é à toa que sintoniza com as estripulias sonoras do outsider Tom Zé, um de seus ídolos e coautor, com Tuzé de Abreu, do Frevo (Pecadinho), que abre o CD e encerra o show em cartaz no Teatro Crowne Plaza. No palco, ela aplica seu aprendizado em teatro musical, como se atuasse em esquetes cômicos de cabaré. Tem algo da ironia de Cida Moreira e do deboche de Silvia Machete, mas é como se aspirasse também a integrar a galeria de Aracy de Almeida, Maria Alcina e Cássia Eller, com estágio em Angela Ro Ro, mas sem rancor.

No show de estreia, entre goles de água e de outra bebida que o copo de plástico branco ocultava, a cantora baiana foi subindo a temperatura a cada música, até que quando chegou na hilária Vergonha (Luciano Salvador Bahia), não se sabia se ela estava fazendo tipo, com a voz empastada, por causa do personagem bebum da cançấo, ou se realmente estava "em águas", como se diz na Bahia. De qualquer maneira, esse combustível contribuiu para:a performance.

As cançốes, mesmo as mais sérias como Medo (J. Velloso), Em Nome de Deus (Sérgio Sampaio) e Coração Selvagem (Belchior), não escapam da flecha do ceticismo. Quando escancara no humor, como em Futebol para Principiantes (Kleber Albuquerque), Barraqueira (Manuela Rodrigues) e Você Gosta (Tom Zé), é pândega. Como Tom Zé, ela compensa certas insuficiências vocais buscando soluçôes no canto falado, na interpretação vigorosa. O efeito de seus "pecadinhos" é imediato: mesmo com repertório praticamente desconhecido, ganha a plateia em cada cançăo, bulindo com a inteligência e a sexualidade, evidenciando cada letra esperta. 
Os músicos que a acompanham no palco - guitarra, teclado, bateria, trompete e baixo - não são os mesmos do $\mathrm{CD}$, mas afinam com as características do projeto. Tanto são aptos a romper em experimentalismo, provocando estranhamento logo de início, como caem no samba de Roque Ferreira (Barulho) e no rock de Chico Buarque (Jorge Maravilha), com desenvoltura. É uma prazerosa combinação de diversão, arte e ousadia, que anda fazendo falta por aí.

Serviço

Marcia Castro. Teatro Crowne Plaza (153 lugs.). Rua Frei Caneca, 1.360. 3ㄹ 21 horas. R\$ 20. Até 25/3.

GARCIA, Lauro Lisboa. Marcia Castro combina arte e boa diversáo. O Estado de S. Paulo. 10 mar. 2008.

2. Identifiquem, no caderno, os elementos a seguir:

a) $\mathrm{O}$ nome do artista.

b) O local, a hora e o dia da apresentação.

c) O ponto de vista do enunciador do texto sobre o show.

d) Um trecho do texto em que o enunciador apresenta um pequeno resumo do show.

e) Outro trecho do texto em que se apresente uma opiniāo do enunciador (Lauro Lisboa Garcia).

f) A finalidade do texto no cotidiano da sociedade.

3. Em certo momento do texto, o enunciador afirma: "De qualquer maneira, esse combustível contribuiu para a performance".

Os mesmos grupos do exercício anterior deverão se reunir para discutir se o texto incentiva o alcoolismo ou nấo. As opiniōes deveráo ser defendidas usando argumentos claros e inteligíveis, e nâo apenas opiniōes pessoais.

4. O termo de origem inglesa performance pode ser adequadamente substituído por:
a) desempenho.
b) perfeição.
c) competiçāo.
d) final.
e) permanência. 
No texto a seguir, destaque as ideias que respondem às perguntas:

Parágrafo 1:

a) O que é uma resenha?

b) Para que serve?

Parágrafo 2: Qual é a diferença entre uma resenha e um simples resumo?

Parágrafo 3:

a) $\mathrm{O}$ que devemos evitar ao escrever uma resenha?

b) Quais são as partes obrigatórias de uma resenha?

\section{O que é uma resenha?}

1. Trata-se de uma síntese que expressa a opiniáo do resenhista sobre um fato cultural: um livro, um filme, um jogo de futebol, uma peça de teatro, uma exposiçāo, uma novela, um show, um conto etc. O objetivo da resenha é orientar o leitor pela enorme quantidade de produçấo cultural que a cada dia aumenta e, por vezes, confunde. A opiniáo apresentada, devidamente argumentada, pode ser favorável ou não ao fato cultural analisado.

2. Embora seja um resumo, a resenha deve ir direto ao ponto, concentrando-se em provar, dentro do texto resenhado, a opiniáo do resenhista. Isso resulta em uma mistura, no corpo do texto, de alguns momentos de pura descrição com outros em que se faz uma crítica fundamentada. Não podemos esquecer que a resenha é um texto argumentativo, ou seja, deve ter um ponto de vista. O objetivo é equilibrar resumo e opinião pessoal sem que o texto perca sua qualidade.

3. Durante a escrita de uma resenha - ou de qualquer texto cujo objetivo seja convencer o outro - devem se evitar expressóes tais como "eu acho", "náo gostei", bem como gírias. Além disso, em uma resenha, devem aparecer o título, a referência da obra resenhada e o resumo ou a síntese do conteúdo contemplado pela avaliação crítica.

Elaborado especialmente para o Säo Paulo faz escola.

\section{Projeto de resenha crítica}

Orientada pelo professor, a classe se organizará para elaborar um projeto de resenha crítica a respeito da exposição das instalaçôes que realizaram na Situação de Aprendizagem anterior e entregá-lo ao professor. Considerem que vocês serão avaliados com base em quatro critérios: 
- presença dos elementos que compóem o gênero resenha;

- ortografia e uso da norma-padrăo (atenção especial ao verbo);

- veracidade das informaçóes e respeito aos direitos humanos;

- pertinência das opiniōes apresentadas.

\section{APRENDENDO A APRENDER}

Um projeto de texto de dissertaçáo escolar é um gênero textual que substitui, em uma redação escolar, o famoso rascunho. Ele permite que o seu texto náo seja um fluir de "achismos", mas um conjunto de argumentos encadeados que se apresenta como produto de uma reflexão.

LANDEIRA, J. L.; BARONTO, L. E. O espaço em gêneros. São Paulo: Salesiana, 2009.

Uma vez pronto, usem o projeto para escrever a resenha da exposiçáo das instalaçôes que realizaram na Situaçăo de Aprendizagem anterior.

Considerem os critérios de correção a seguir. Completem a parte de vocês somente depois de produzido o texto.

\begin{tabular}{|l|l|l|l|l|}
\hline \multicolumn{1}{|c|}{ Critérios } & Está o.k. & $\begin{array}{c}\text { Precisa } \\
\text { melhorar }\end{array}$ & Está o.k. & $\begin{array}{c}\text { Precisa } \\
\text { melhorar }\end{array}$ \\
\hline $\begin{array}{l}\text { Presença dos elemen- } \\
\text { tos que compóem o } \\
\text { gênero resenha crítica }\end{array}$ & & & & \\
\hline $\begin{array}{l}\text { Ortografia e uso da } \\
\text { norma-padráo (aten- } \\
\text { çáo especial ao verbo) }\end{array}$ & & & & \\
\hline $\begin{array}{l}\text { Veracidade das infor- } \\
\text { maçóes e respeito aos } \\
\text { direitos humanos }\end{array}$ & & & & \\
\hline $\begin{array}{l}\text { Pertinência das opi- } \\
\text { nióes apresentadas }\end{array}$ & & & & \\
\hline
\end{tabular}


Depois que o professor corrigir a resenha crítica, ela será devolvida. Compare o ponto de vista do professor com o seu. Discuta em classe aspectos da escrita que todos os alunos podem aprimorar. Reescreva o texto seguindo as orientaçóes dadas e devolva-o para correção final, com a primeira versão.

\section{PARA SABER MAIS}

Os sites a seguir poderăo ajudá-los em suas pesquisas sobre resenhas:

- <http://www.pucrs.br/gpt/resenha.php>. Acesso em: 5 mar. 2010.

- $\quad$ http://www.cesnors.ufsm.br/projetos/textos-academicos/RESENHA\%20CRI TICA.doc/view>. Acesso em: 5 mar. 2010.

- <http://www.ucb.br/prg/comsocial/cceh/normas_organinfo_resumo_critico. htm>. Acesso em: 5 mar. 2010.

- <http://www.moodle.ufba.br/mod/resource/view.php?id=19103>. Acesso em: 5 mar. 2010.

O que eu aprendi... 
ANEXO B - "O que faz de alguém um escritor?" ( $C A$, Vol. 1, 2ª série EM)

\section{PARA SABER MAIS}

O escritor Luís Fernando Veríssimo lançou o livro Comédias da vida privada (Porto Alegre: LP\&M, 1996), em que situaçóes hilárias são vividas por heróis anônimos. Procure um exemplar na biblioteca ou na sala de leitura da escola e aproveite a leitura.

A internet faz uso constante da palavra. O site <http://www.releituras.com> apresenta uma variedade de textos literários e biografias de seus autores. Além disso, o site <http:// educacao.uol.com.br/ensino-medio> traz inúmeras possibilidades para você ampliar seus conhecimentos.

\section{SITUAÇÃO DE APRENDIZAGEM 2} O QUE FAZ DE ALGUÉM UM ESCRITOR?

Com esta Situação de Aprendizagem você verá que não é tão difícil escrever bons textos. Uma boa orientaçáo, acompanhada de um pouco de empenho, pode ser a receita que o motive para uma escrita significativa.

\section{Para começo de conversa}

Escrever pode não ser uma tarefa fácil, mas também não é um dom para seres "inspirados por entidades divinas". Todas as pessoas podem escrever bons textos se forem devidamente orientadas e se empenharem. O objetivo da atividade a seguir é prepará-lo para ler artigos de opinião jornalísticos e para aprender a escrevê-los. A leitura e a escrita desse gênero textual favorecem o desenvolvimento da crítica e da argumentaçáo, importantes para a vida em sociedade e para o vestibular.

\section{Notícia ou opinião?}

1. Identifique quais dos textos a seguir sáo parte de uma notícia (ou reportagem) e quais sāo parte de um artigo de opiniáo:

I. "[...] O Brasil precisa de agricultura livre de transgênicos para suprir o mercado interno com alimentos saudáveis e baratos e, depois, vender os excedentes aos ricos mercados da Europa, Japão e China, que rejeitam OGMs. Eles pagam até $10 \%$ a mais para se ver livres do milho 'frankenstein'. A soja certificada como não transgênica recebe dos europeus prêmio de até 8 dólares por tonelada [...]." 
II. "[...] A discussão em torno da possível criação de uma zona livre da plantação de gráos transgênicos nos Estados do Paraná e de Santa Catarina causou reaçáo do governo do Rio Grande do Sul.

Enquanto paranaenses e catarinenses analisam supostas vantagens econômicas com a produçāo de alimentos sem modificação genética, gaúchos apostam que os produtores irāo rejeitar determinaçóes contrárias à liberaçáo do cultivo de sementes transgênicas [...]"

("PR e SC discutem criar 'zona livre'; RS reage", de Mari Tortato, Léo Gerchmann e Jairo Marques. Follha de S.Panlo, 2 out. 2003.)

III. "[...] Na última safra, mais de $80 \%$ da soja plantada no Estado (RS) foi transgênica. Os agricultores gaúchos esperam a decisáo do governo para saber se poderāo utilizar sementes do organismo modificado geneticamente para a próxima safra ou não. Publicamente, já disseram que, mesmo que sem permissão, pretendem repetir o uso [...]."

2. Justifique sua resposta à questão anterior dizendo por que definiu os textos como notícia ou como artigo de opiniáo.

3. Identifique nos trechos de opiniāo qual questáo está sendo discutida e qual a posiçâo do autor nessa questáo.

\section{Discussāo oral}

1. Qual é a diferença entre os dois enunciados a seguir?

- A Terra é um planeta do sistema solar.

- O rap é uma música de mau gosto.

2. Para convencer seus colegas de que você tem razáo sobre determinado assunto, o que você faz? 


\section{Questốes controversas}

1. Examine o texto a seguir.

\section{Leitura e Análise de Texto}

\section{A redação e o vestibular}

A redação nos chamados grandes vestibulares não é bem o que se apregoa no Ensino Médio. Para atender ao que Unicamp, Unesp e USP, por exemplo, pedem a seus futuros alunos, o candidato deve conseguir superar o modelo oferecido pela maioria dos colégios e cursinhos.

Uma redação que siga uma estrutura muito divulgada de introduçáo, com resumo do assunto abordado, desenvolvimento genérico do tema proposto e conclusāo retomando a introduçāo, consegue no máximo uma nota mediana. Muitas redaçóes mal pontuadas escondem o triste paradoxo de o candidato acreditar que havia feito um bom trabalho.

$[\ldots]$

LANDEIRA, J. L. A redaçāo e o vestibular. In: Folha de S.Paulo. 17 fev. 2004. Disponivel em <http://www1 folha.uol.com.br/folha/ sinapse/ult 1063u739.shtml>. Acesso em: 6 nov. 2009.

2. Responda às questóes:

a) Qual é o assunto tratado no texto?

b) Sobre esse assunto, o autor defende a opiniāo de que:

I. Fazer uma boa redaçáo deixou de ser importante para aprovaçâo em vestibulares de instituiçōes sérias de Ensino Superior.

II. As técnicas de redação ensinadas pela maioria das instituiçóes educacionais nâo preparam o aluno para o vestibular.

III. Os alunos sáo muito fracos na sua capacidade de aprender e por isso náo conseguem fazer boas redaçōes.

IV. É obrigaçáo do leitor de uma redaçáo se esforçar para entender o que o autor quis dizer com aquilo que escreveu. 


\section{APRENDENDO A APRENDER}

Não esqueça que uma boa argumentaçáo exige que se discuta uma questáo controversa ou polêmica, ou seja, uma afirmaçāo cuja resposta não seja única, permitindo diferentes posicionamentos.

3. Leia atentamente os trechos a seguir e identifique a questáo ${ }^{1}$ controversa subjacente:

I. "Prevenir é um grande trunfo para vencer mais algumas batalhas contra a AIDS, no entanto isso muitas vezes é ofuscado pelo desejo e esperança que cercam a busca pela cura: a pesquisa científica, a vacina, o avanço no desenvolvimento de medicamentos e a melhoria na assistência, que apresenta um caráter de maior urgência e de resultados imediatos. Assim, de maneira geral, a prevençáo acaba ocupando uma posição secundária dentro das políticas de saúde voltadas à AIDS, sendo abordada em açōes pontuais e isoladas e desarticuladas entre si, que náo resultam em mudanças de impacto e sustentáveis."

José Carlos Veloso/Gapa - Grupo de apoio à prevenção à Aids-Gapa:BR/SP. Agência Carta Maior, 18 set. 2004. Disponivel em: <http://www.gapabrsp.org.brs.

II. "O que me espanta é que os jovens se queixem de que têm poucas fontes de conhecimento da sexualidade. Só nas últimas décadas, as escolas começaram a introduzir o tema nas salas de aula, assim mesmo com ênfase na higiene corporal, tendo em vista as DSTs. A família, aos poucos, começa a derrubar tabus, exceto nas classes populares, onde a falta de conhecimento obriga os jovens a aprenderem 'na rua', como se dizia na minha geraçāo. Hoje, 'aprende-se' na televisāo. Primeiro, com a exacerbaçáo do voyeurismo, tipo Big Brother. É o bordel despejado, via eletrônica, no quarto das crianças ou na sala da casa. Sem que famílias, escolas e igrejas cuidem da educação do olhar de crianças e jovens."

Frei Betto, Revista Caros Amigos, ediçáo n. 87.

III. "As empresas de motoboys estavam a mil, cada motoqueiro ganhava um salário que compensava o risco, assim como também foram os lotaçóes. Agora vai começar o cadastramento, 
o controle, e a verdade é que o Estado está organizado para náo deixar que a elite perca poder econômico e político, estáo todos preparados para boicotar qualquer tentativa de crescimento da classe tida por eles como mais baixa, que na real somos nós."

Ferréz, Revista Caros Amigos, ediçăo n. 86.

4. Retorne ao trecho inicial do artigo de opiniāo $A$ redaçáo e o vestibular, leia o segundo trecho a seguir e responda às questóes.

\section{$[\ldots]$}

Antes de tudo, o perfil que as consideradas grandes universidades procuram é o do aluno que tenha algo a dizer. Por exemplo, o tema deste ano da Fuvest, o tempo, exigia uma abstraçáo ao mesmo tempo científica, sociológica e filosófica que não é comum na escola brasileira e não faz parte do cardápio usual dos cursinhos.

\section{$[\ldots]$}

Sobre um tema como o tempo, muitos conseguiriam, nesse último vestibular, citar conceitos de sala de aula como "o tempo é relativo" ou "o passado explica o presente". Contudo é reduzido o número dos que justificariam razoavelmente tais teses fugindo de clichês mal formulados, como "se Hitler tivesse estudado o passado, nāo teria repetido o erro de Napoleāo, ao invadir a Rússia no inverno". Poucos pensariam na possibilidade de Hitler dispor de um armamento superior ao que Napoleão utilizara um século antes. A questáo poderia ser náo de desconhecimento histórico, mas de orgulho e crença na tecnologia da época.

$[\ldots]$

LANDEIRA, J. L. A redaçáo e o vestibular. In: Folha de S.Paulo. 17 fev. 2004. Disponível em: <htup://wwwl.folha.uol.com.br/folha/ sinapse/ult 1063u739.shtml>. Acesso em: 6 nov. 2009.

a) Qual é a relaçáo que o segundo trecho estabelece com o inicial?

b) Que argumento sustenta a opiniáo do autor apresentada na introduçāo do artigo?

c) Que exemplo ele fornece para justificar seu argumento?

1. Assinale as alternativas que apresentam uma questáo controversa: 
a) ( ) A água é importante para a saúde da vida humana.

b) ( ) O trabalho infantil desrespeita os direitos da criança.

c) ( ) As drogas prejudicam a saúde.

d) ( ) A proibiçāo do consumo de álcool reprime a liberdade.

e) ( ) Só a prevenção pode erradicar as DSTs em nossa sociedade.

2. Explique os motivos de sua resposta na questão anterior em cada alternativa.

3. Procure um artigo de opiniāo em jornais e revistas, na internet e no livro didático. Responda:

a) Qual é o título do artigo?

b) Identifique a fonte onde o encontrou.

c) O título do texto é apropriado, ou seja, ele sintetiza o assunto discutido?

d) Qual é a questāo polêmica apresentada?

e) Os argumentos presentes são adequados para defender essa questão?

\section{Leitura e Análise de Texto}

\section{Passagem pela adolescência}

"Filho criado, trabalho redobrado." Esse conhecido ditado popular ganha sentido quando chega a adolescência. Nessa fase, o filho já não precisa dos cuidados que os pais dedicam à criança, táo dependente. Mas, por outro lado, o que ele ganha de liberdade para viver a própria vida resulta em diversas e sérias preocupaçóes aos pais. Temos a tendência a considerar a adolescência mais problemática para os pais do que para os filhos. É que, como eles já gozam de liberdade para sair, festejar e comemorar sempre que possível com colegas e amigos de mesma idade e estão sempre prontos a isso, parece que a vida deles é uma eterna festa. Mas vamos com calma porque náo é bem assim.

Se a vida com os filhos adolescentes, que alguns teimam em considerar um fato aborrecedor, é complexa e delicada, a vida deles também o é. $\mathrm{Na}$ verdade, o fenômeno da adolescência, principalmente no mundo contemporâneo, é bem mais complicado de ser vivido pelos próprios jovens do que por seus pais. Vejamos dois motivos importantes. 
1. Após ler com atençáo o título e o trecho inicial que apresentamos, responda no caderno:

- O que espera encontrar no restante do texto? Por quê?

2. Agora, leia com atenção a continuaçāo do texto e responda às questôes a seguir, no caderno:

Em primeiro lugar, deixar de ser criança é se defrontar com inúmeros problemas da vida que, antes, pareciam nāo existir: eles permaneciam camuflados ou ignorados porque eram da responsabilidade só dos pais. Hoje, esse quadro é mais agudo ainda, já que muitos pais escolheram tutelar integralmente a vida dos filhos por muito mais tempo.

Quando o filho, ainda na infância, enfrenta dissabores na convivência com colegas ou pena para construir relaçōes na escola, quando se afasta das dificuldades que surgem na vida escolar - sua primeira e exclusiva responsabilidade -, quando se envolve em conflitos, comete erros, não dá conta do recado etc., os pais logo se colocam em cena. Dessa forma, poupam o filho de enfrentar seus problemas no presente, é claro, mas também passam a ideia de que eles náo existem por muito mais tempo.

É bom lembrar que a escola - no ciclo fundamental - deveria ser a primeira grande batalha da vida que o filho teria de enfrentar sozinho, apenas com seus recursos, como experiência de aprender a se conhecer, a viver em comunidade e a usar seu potencial com disciplina para dar conta de dar os passos com suas próprias pernas.

Em segundo lugar, o contexto sociocultural globalizado atual, com ideais como consumo, felicidade e juventude eterna, por exemplo, compromete de largada o processo de amadurecimento típico da adolescência, que exige certa dose de solidão para a estruturação de tantas vivências e, principalmente, interlocução. E com quem os adolescentes contam para conversar?

Eles precisam, nessa época de passagem para a vida adulta, de pessoas dispostas a assumir o lugar da maturidade e da experiência com olhar crítico sobre as questôes existenciais e da vida em sociedade para estabelecer com eles um diálogo interrogador. Várias pesquisas já mostraram que os jovens dão grande valor aos pais e aos professores em suas vidas. Entretanto, parece que estamos muito mais comprometidos com a juventude do que eles mesmos.

Quem leva a sério questóes importantes para eles em temas como política, sexualidade, drogas, ética, depressão e suicídio, vida em família, vida escolar, violência, relaçōes amorosas e fidelidade, racismo, trabalho etc.? Quando digo levar a sério me refiro a considerar o que eles dizem e dialogar com propriedade, e não com moralismo ou com excesso de jovialidade. E, desse mal, padecem muitos pais e professores que com eles convivem.

Os adolescentes nāo conseguem desfrutar da solidāo necessária nessa época da vida, mas parece que se encontram sozinhos na aventura de aprender a se tornarem adultos. Bem que merecem nossa companhia, năo?

SAYÃO, Rosely. Passagem pela adolescència. Folha de S.Paulo, São Paulo, 21 fev. 2008. Caderno Equilibrio, p. 12. 
a) Qual é a questāo controversa discutida no artigo?

b) Quais são os argumentos que o enunciador utiliza para defender sua opiniâo?

c) O texto elabora uma proposta de intervenção solidária, respeitando os valores humanos? $\mathrm{Se}$ sim, qual?

3. Forme uma dupla com um colega. Com base em alguns temas sugeridos pelo professor, pensem em uma questáo polêmica própria para um artigo de opiniáo e anotem no caderno.

4. Agora, identifiquem dois ou três argumentos que defendem essa questáo polêmica ou tese.

5. Escolham um desses argumentos e encontrem um ou dois exemplos para ele.

6. Com as respostas dadas às questóes anteriores, produzam um artigo de opiniāo. Ao elaborar o texto, certifiquem-se de que ele apresente os seguintes critérios para correção:

- ter aproximadamente 30 linhas;

- defender uma questáo controversa por meio de argumentos;

- apresentar boa organização e clareza das ideias;

- ser escrito com letra legível.

7. Após a escrita do texto, troquem-no com outra dupla e anotem, a lápis, no texto de seus colegas, sugestóes para melhorar a escrita. Quando seu texto lhes for devolvido, vejam a opiniāo de seus colegas. Vocês não são obrigados a segui-las, mas verifiquem se elas melhorariam seu texto. Finalmente, após as mudanças que considerarem oportunas, entreguem-no ao professor.

8. Depois de corrigido, o artigo de opiniāo será devolvido a vocês. Reescrevam-no seguindo as orientaçóes dadas e o entreguem para a correção final.

\section{Conectando o texto}

Faça o exercício a seguir²:

1. Leia com atençâo os períodos a seguir e inclua os organizadores textuais em destaque nas colunas adequadas, de acordo com a funçáo que desempenham em cada período, usando um quadro semelhante ao que segue: 


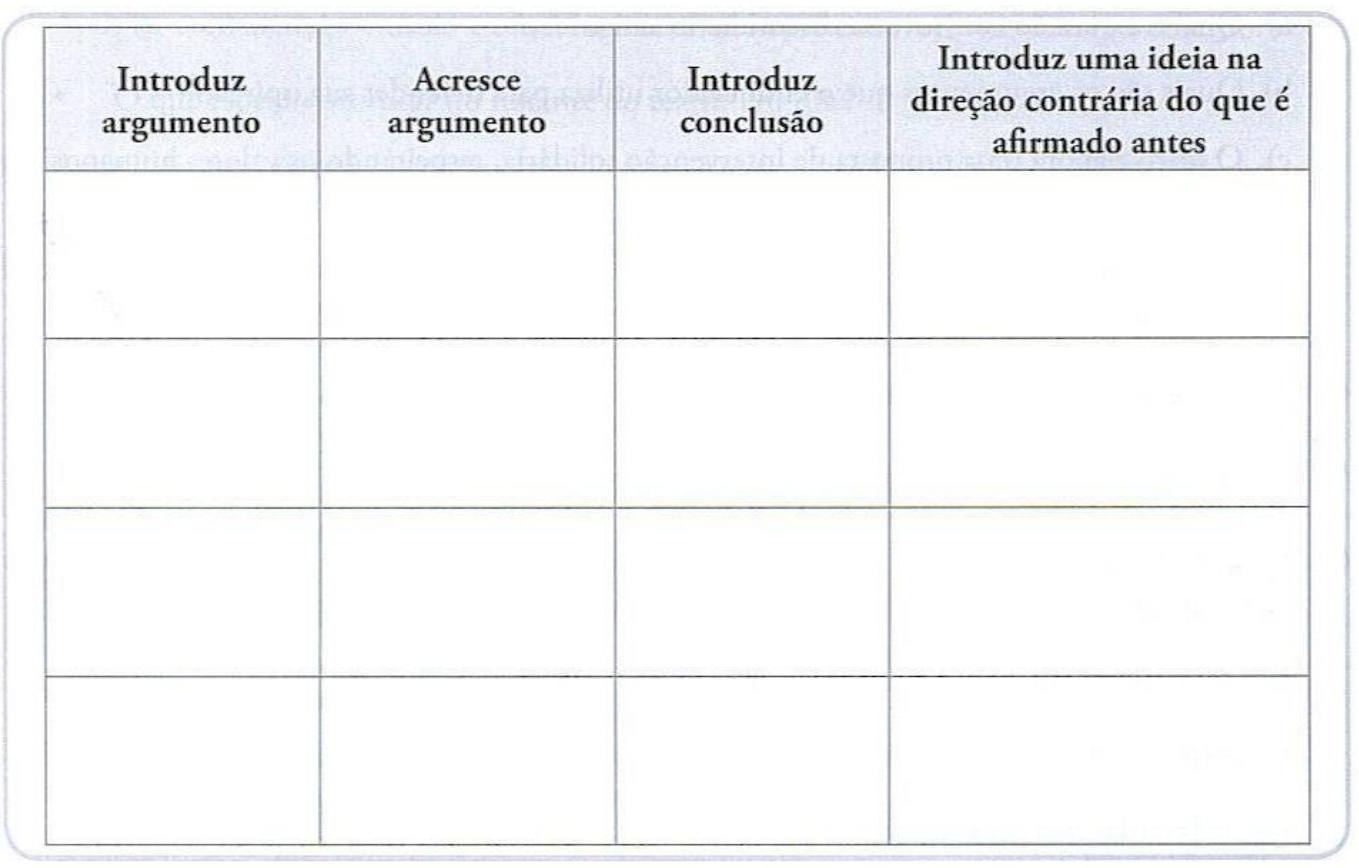

- Não se pode de maneira simplista afirmar que o brasileiro náo gosta de ler, pois é preciso considerar que muitos deles ainda hoje não têm acesso a livros e outros tantos nem sequer sabem ler.

- As músicas eram de mau gosto, o bolo estava seco, a bebida, quente. Em suma, a festa foi um fracasso.

- O filme nāo é muito bom. A fotografia é escura demais, o roteiro está cheio de falhas de continuidade. Além disso, os atores trabalham muito mal.

- A bebida alcoólica diminui a capacidade do homem de responder imediatamente aos estímulos do mundo externo. Portanto, nāo se deve dirigir alcoolizado.

- Criar condiçóes de desenvolvimento econômico é o melhor modo de ajudar a população carente. Entretanto, muitos governantes preferem implementar políticas assistencialistas. 
- No Egito antigo, a cerveja era considerada a bebida nacional. Os egípcios acreditavam que ela possuía propriedades curativas, especialmente contra picadas de escorpiāo. A bebida também era utilizada como produto de beleza pelas mulheres, que acreditavam em seus poderes de rejuvenescimento.

- "A reserva de vagas para estudante de escolas públicas náo resolve a questão, como também náo assegura que os beneficiados sejam os mais pobres, uma vez que náo há na proposta corte por renda. Não é improvável que estudantes menos qualificados de classes mais abastadas migrem pata o ensino público visando beneficiar-se da cota." (Folha de S.Paulo, 30 maio 2004.)

- O ambiente era bastante hostil, porém muitos animais sobreviveram lá.

- O Brasil é uma naçáo jovem, posto que $42,1 \%$ da população tem menos de 18 anos.

1. Encaixe, nos espaços devidos, as palavras destacadas no texto Progressáo textual e conectores.

\section{Progressāo textual e conectores}

A continuidade do texto envolve a progressão daquilo que se diz. Ao escrever um texto argumentativo, não podemos apenas "encher" linhas, mas defender uma questão controversa com argumentos consistentes. A continuidade de sentidos é como um constante ir e vir: de um lado, aquilo que já é sabido pelo leitor e, de outro, aquilo que ele virá a saber. Para esse fim, é necessária a cuidadosa articulaçâo entre as diferentes partes do texto por meio do uso adequado de conectores.

Chamamos de conectores as palavras ou expressóes que conectam partes do texto entre si possibilitando a construçáo do sentido. Eles estabelecem diferentes relaçóes como oposiçấo (mas, porém etc.); causalidade (pois, porque etc.); temporalidade (quando etc.); consequência (por isso, entāo etc.); condiçâo (se, caso etc.); finalidade (a fim de que, para etc.). 


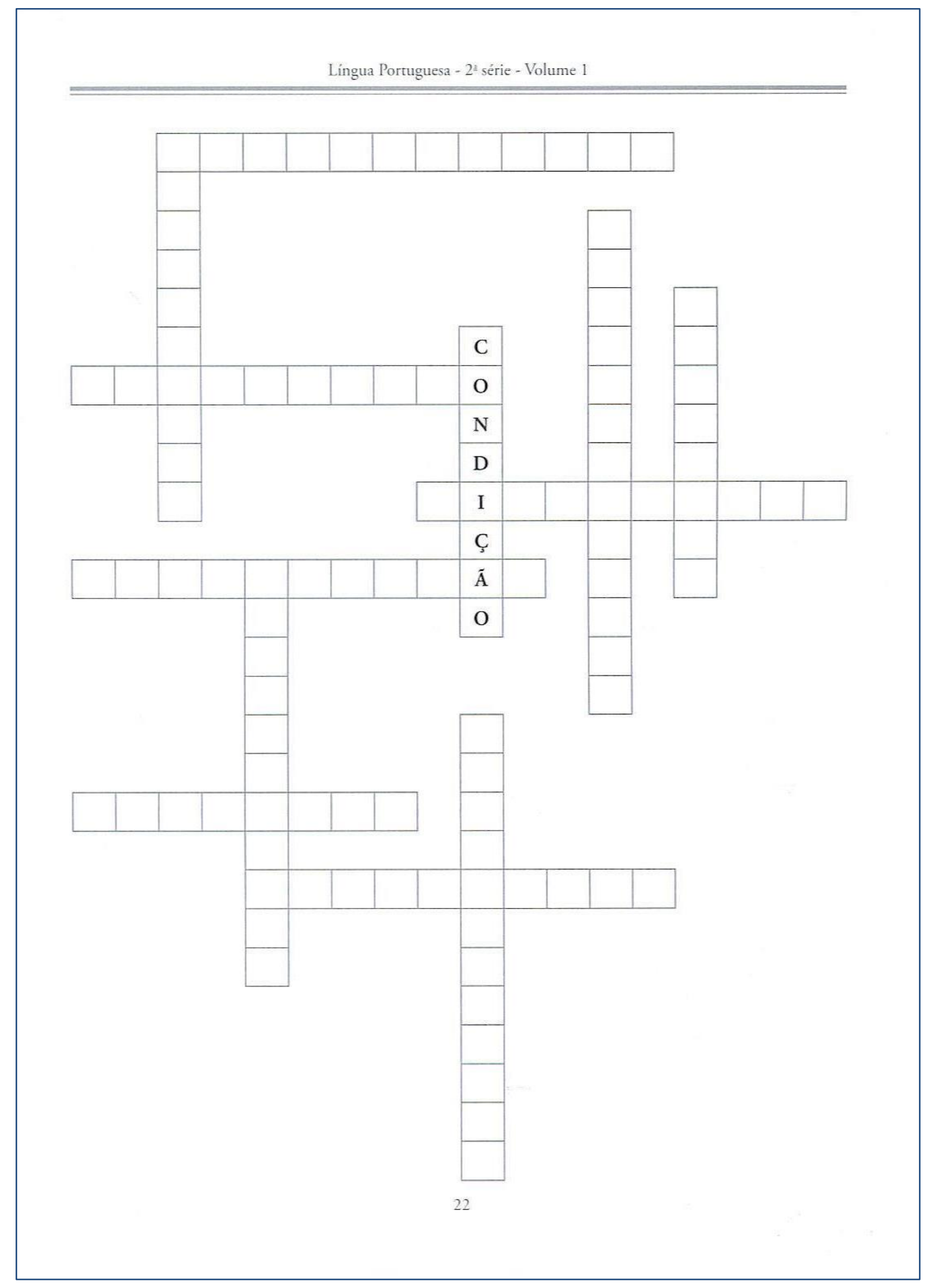


2. Rebeca é uma aluna que raramente faz as liçōes com atençāo. Ela termina correndo para tentar sair mais cedo da classe. Um dia ela fez a liçāo rapidinho, contudo a reaçáo da professora não foi a esperada. Qual das duas frases vai ser usada por Rebeca para contar o que aconteceu?

a) Terminei a liçáo mais cedo, portanto a professora não me deixou sair antes da aula acabar.

b) Terminei a liçāo mais cedo, mas a professora nāo me deixou sair antes da aula acabar.

Explique o porquê de sua resposta.

Em dupla ou em trio, elaborem, no caderno, um texto sobre o que aprenderam em relação aos assuntos desenvolvidos nesta Situaçâo de Aprendizagem. Usem adequadamente os conceitos estudados em sala de aula até agora, fazendo as consultas que acharem necessárias.

Ao final, apresentem oralmente o texto à classe.

\section{PARA SABER MAIS}

O jornal Folha de S.Paulo publica, todas as segundas-feiras, o caderno Folhateen. Nele você encontrará matérias direcionadas ao público adolescente.

O site <http://vestibular.uol.com.br/simulado> traz uma variedade de testes simulados com questóes de vestibular das principais instituiçóes públicas.

\section{SITUAÇÃO DE APRENDIZAGEM 3 PARA GOSTAR DE LER LITERATURA}

As atividades desta Situação de Aprendizagem farão com que você veja o texto literário como obra que emociona e perpetua a essência humana.

\section{Para começo de conversa}

\section{No alto céu e na boca dos poetas: a lua!}


ANEXO C - "Elaborando um projeto de dissertação" (CA, Vol. 2, 3ª série EM)

\section{PARA SABER MAIS}

O livro Vidas secas, de Graciliano Ramos, merece ser lido com a atençāo de quem deseja adquirir cultura e desenvolver a habilidade de refletir. Ele certamente faz parte do acervo da biblioteca ou sala de leitura de sua escola.

O filme Vidas secas (direção de Nelson Pereira dos Santos, 1963, 103 min) é uma interessante adaptaçăo da obra de Graciliano Ramos. Você verá que nâo é apenas o livro transformado em filme, mas uma maneira muito especial de ver os problemas que preocupavam o escritor e, de certo modo, preocupam todos nós.

Os sites a seguir também são uma ótima fonte de pesquisa: <http://www.releituras. com>; <http://www.bibvirt.futuro.usp.br>; <http://www.tvebrasil.com.br>; <http://www. mac.usp.br>.

\section{SITUAÇĀO DE APRENDIZAGEM 2} ELABORANDO UM PROJETO DE DISSERTAÇÃO

\section{Para começo de conversa}

\section{Tipologia textual: a argumentação}

As profissóes que exigem uma formação específica no chamado Ensino Superior, depois de concluído o Ensino Médio, são divididas em áreas, como segue:

- Ciências humanas e sociais: Administração, Arquitetura e Urbanismo, Ciências Sociais, Direito, Gastronomia, Publicidade e Propaganda, Licenciaturas em geral, Psicologia, Turismo etc.

- Engenharias: Ambiental, Elétrica, Civil, Mecânica, Naval, de Alimentos, de Agricultura, de Petróleo e Gás, da Computação, Biomédica etc.

- Ciências exatas: Astronomia, Ciências Contábeis, Ciência da Computação, Geofisica, Meteorologia, Ciências Aeronáuticas etc.

- Ciências biológicas: Biotecnologia, Ecologia, Farmácia, Medicina, Medicina Veterinária, $\mathrm{Nu}$ triçáo, Oceanografia, Odontologia, Zootecnia etc.

- Ciências agrárias: Agronomia, Ecologia, Engenharia de Horticultura.

- Artes: Cinema e Video, Artes Plásticas, Artes Cênicas, Audiovisual, Multimídia etc.

Responda no caderno: qual área e profissão você gostaria de seguir? Por quê? 
1. Relacione as frases-síntese com os parágrafos do texto a seguir. Observe que uma frase vai sobrar.

I. A linguagem verbal humana representa uma capacidade de comunicação muito superior às demais encontradas na natureza.

II. A invençāo da escrita é um dos maiores marcos da história da humanidade.

III. Animais e plantas apresentam a capacidade de comunicação.

IV. A comunicação faz parte do processo da vida dos seres humanos.

\section{Comunicação é vida}

( ) A comunicação faz parte do processo da vida. Quando nascemos, mesmo antes de começarmos a falar, já nos comunicamos com nossos pais. Apenas pelo choro da criança, uma mãe pode identificar quais sâo suas necessidades, se ela está com sono, fome ou alguma dor. Para cada necessidade, há um choro diferente. Pelas expressōes, gestos e sons emitidos pela criança, a máe sabe se ela está bem ou não.

( ) Podemos nos comunicar com animais, ensiná-los, conhecer suas emoçōes, saber se estão alegres ou agressivos. Também podemos observar a comunicaçáo entre eles, os sons que emitem, os sinais físicos de que se utilizam para ameaçar ou se proteger, reproduzir, marcar e proteger um território. Até uma planta pode emitir sinais que alcançam outras plantas por meio de elementos químicos que liberam no ar.

( ) O ser humano, contudo, por meio da fala, da linguagem verbal, desenvolveu uma capacidade de comunicação bem mais complexa do que aquela que encontramos no resto da natureza.

PAIS, Paulo Marcelo Vieira. Tecnologias de comunicaçáo e informaçáo: presença constante em nossas vidas. In: Linguagens, códigos e suas tecnologias: livro do estudante (Ensino Médio). MURRIE, Zuleika F. (coord.). Brasilia: MEC: INEP, 2006. p. 157.

2. Leia o artigo de opiniáo a seguir. Procure identificar a tese e os argumentos que o constituem.

\section{A leitura e a cidadania}

Ler, hoje em dia, tornou-se uma forma essencial de nos constituirmos como parte da sociedade, como cidadāos. Em todos os lugares, é necessário ler e, portanto, interpretar algo. A necessidade de desvendar caracteres, letreiros, números faz com que passemos a olhar, a questionar, a buscar decifrar o desconhecido para atender às diferentes facetas de nossa vida. A necessidade de ler transforma o nosso olhar e esse novo olhar que a leitura desenvolve é uma forma nova e melhor de ser cidadāo.

Uma vez que nos tornamos leitores da palavra, invariavelmente, leremos o mundo sob a influência dela. Isso ocorre de modo consciente ou nâo. Em nossa sociedade letrada, 
mundo e palavra estão de tal modo associados que é impossível separá-los. Ler a palavra é também ler o mundo e passar a vê-lo de outro modo.

Mas ler é uma prática que náo se reduz às palavras. Antes mesmo de ler a palavra, já lemos o universo que nos permeia: um cartaz, uma imagem, um som, um olhar, um gesto. Sáo muitas as razóes para a leitura. Todas elas permitem que tenhamos uma melhor experiência de cidadania. Cada leitor tem a sua maneira de perceber e de atribuir significado ao que lê, mas a leitura é essencial para vivermos bem em sociedade.

Elaborado especialmente para o Säo Paulo faz escola.

Qual é a tese (posiçáo do enunciador) defendida no texto?

a) A leitura melhora nossa experiência de cidadania.

b) A leitura é importante.

c) As pessoas que náo leem sáo ignorantes.

d) Todos aqueles que leem muito se tornam ricos e bem-sucedidos financeiramente.

3. Em um texto argumentativo, o autor procura convencer os leitores, com argumentos, de que sua tese é correta. Identifique, no artigo de opinåo que leu, um argumento usado para defender a ideia expressa na tese e explique, no caderno, como ele atende ao objetivo do autor.

4. Tome uma posiçáo para cada tema a seguir e, no caderno, elabore uma tese que esclareça sua posição para possíveis leitores: violência; aborto; sexo; leitura; política; pena de morte; imprensa.

\section{LIÇÃO DE CASA}

1. Identifique os itens cujas frases mantêm a seguinte estrutura:

Sujeito + verbo (ou locuçáo verbal) + complementos ou predicativos

a) A comunicação faz parte do processo da vida.

b) Podemos nos comunicar com animais.

c) Apenas pelo choro da criança.

d) Uma máe pode identificar as necessidades de uma criança.

e) Faz parte do processo e é muito importante isso.

f) Comunicaçáo é vida. 
2. Elabore, no caderno, um argumento para justificar as teses a seguir. Siga o modelo.

Tese: Boa saúde depende também de bons amigos.

Argumento: bons amigos melhoram nosso humor; o que nos traz melhor saúde.

a) Tese: Desenvolver a leitura amplia a nossa qualidade de vida.

b) Tese: Os vícios corrompem a dignidade humana.

c) Tese: Todos devem se preocupar com sua formação cultural.

d) Tese: O lazer diminui o estresse.

\section{Um gênero argumentativo: a dissertaçáo escolar}

1. A seguir, você examinará alguns enunciados extraídos de vestibulares. Identifique o que há em comum entre eles e anote no caderno.

- Redija uma dissertaçáo, a tinta, desenvolvendo um tema presente nos textos abaixo.

- (Enem) Com base nas ideias presentes nos textos acima, redija uma dissertaçáo sobre o tema:

- Baseando-se em sua experiência, nos textos literários mencionados e no texto jornalístico a seguir, escreva uma redaçáo, no gênero dissertativo, sobre o seguinte tema:

2. Orientado pelo professor e com base nos conhecimentos adquiridos, procure definir, com suas palavras, o conceito de dissertaçáo escolar como gênero dissertativo. Anote no caderno.

\section{Preparando o caminho para o texto}

A afirmaçáo: "A violência das cidades conduz a sérios problemas familiares" tem como palavras-chave "violência" e "problemas familiares". Em um texto argumentativo, como uma dissertação escolar para um exame de vestibular, náo poderíamos deixar essas duas palavras sem esclarecimentos. Um dos modos de esclarecer palavras é dar definiçóes para elas; outro é estabelecer, dentro de um tema amplo (como problemas familiares, por exemplo), quais aspectos ou situaçôes seráo discutidos.

1. Responda às questóes no caderno:

a) De quais formas diferentes de violência você tem conhecimento?

b) Que diferentes problemas familiares sáo comuns na comunidade em que mora? 


\section{APRENDENDO A APRENDER}

A argumentação é um processo textual que exige organização: os argumentos devem se encadear uns aos outros, dando ao leitor a sensaçáo de unidade. Uma excelente ideia pode ser perdida se não soubermos organizar os argumentos ou se estes forem fracos.

2. Pedro é estagiário em um importante jornal do estado de São Paulo. Como um dos redatores do caderno dirigido aos jovens e adolescentes fica repentinamente doente, Pedro é convidado a fazer um artigo de opiniáo sobre o tema imprensa. Entusiasmado, logo pensa na seguinte tese: $A$ imprensa deve ser responsável ao transmitir informaçōes. Entretanto, antes de escrever, ele precisa organizar as ideias que vai usar na construção de seu texto. O primeiro passo é definir de modo claro as palavras-chave de sua tese. Por exemplo, o conceito de responsabilidade muda muito de pessoa para pessoa, e Pedro necessita ter bem claro com qual sentido essa palavra aparecerá no texto. Ele náo quer errar e resolve telefonar para Heloísa, sua amiga e também jornalista.

a) Leia o diálogo de Pedro e Heloísa no texto a seguir e o complete, tomando o lugar de Heloísa e dando as respostas que ela daria.

\section{TRIMMMMMMMMMMMM}

Heloísa: Alô!

Pedro: Oi, Helô, tô precisando de você, gata! Seguinte: vou escrever um artigo de opiniăo com a tese $A$ imprensa deve ser responsável ao transmitir informaçōes. $\mathrm{O}$ que você acha da ideia?

\section{Heloísa:}

Pedro: Então, o problema é o seguinte, gata, como você acha que eu tenho de delimitar as palavras-chave? Ou seja, o que deve ser, no meu texto, responsabilidade? De que imprensa você acha que eu devo falar? E informaçóes: devo falar de todas as informaçōes ou só de algumas? Quais? Puxa! Estou superatrapalhado. Você me ajuda?

\section{Heloísa:}

Pedro: Olha, Helô, muito obrigado, tá? Fico devendo mais essa pra você! Mas, se eu precisar de mais alguma coisa, volto a te ligar, ok? 
b) Uma vez resolvida a questão das palavras-chave, Pedro precisa agora criar alguns argumentos para defender sua tese. Depois de muito pensar, ele opta por três argumentos que the parecem bons:

- as informaçōes da imprensa são o principal instrumento de manutençáo da democracia;

- a sociedade precisa conhecer a verdade dos fatos;

- acontecimentos importantes para a naçáo náo podem ser tratados como uma simples distração.

Ele escreve, entáo, um e-mail para sua amiga Heloísa apresentando-lhe os argumentos e pedindo a ela uma opiniáo. E o termina com as seguintes palavras: "Me diz logo se vc gostou dos argumentos que bolei e p q, o.k.?".

Agora, escreva no caderno a resposta de Heloísa com sua opiniáo sobre a qualidade dos argumentos. Leve em conta que o texto de Pedro se dirige a um tipo muito especial de leitor e é pensando nesse leitor que decidimos se os argumentos sâo bons ou náo.

c) Pedro decide elaborar um projeto que o ajude a visualizar seu texto. O problema, agora, é dar hierarquia aos argumentos, ou seja, decidir qual deles é o mais importante e qual o menos importante. Complete o quadro a seguir, tomando as decisóes no lugar de Pedro.

\begin{tabular}{|c|c|}
\hline \multicolumn{2}{|c|}{ Projeto de texto } \\
\hline Tema & Imprensa \\
\hline Tese & $\begin{array}{c}\text { A imprensa deve ser responsável } \\
\text { ao transmitir informaçóes }\end{array}$ \\
\hline Termos que vou definir no texto & Responsabilidade \\
\hline Argumento menos importante (1) & \\
\hline Argumento médio (2) & \\
\hline Argumento mais importante (3) & \\
\hline
\end{tabular}

d) No caderno, justifique as escolhas que fez no exercício anterior. 
1. Associe a ideia presente no grupo de expressōes a cada item:
a) concordar
( ) certamente, sem dúvida alguma, sabe-se bem que, é evidente que
b) duvidar
( ) nāo é difícil concordar com, concordamos com, nāo é fácil negar que
c) dar certeza
( ) talvez, é possível que, é provável que, não há garantias de que
d) alternar
( ) por um lado... por outro lado, estabelecer relaçōes entre ... e ..., sob outra perspectiva

2. Complete o texto a seguir com os conectores que faltam. Encontre-os no caça-palavras:

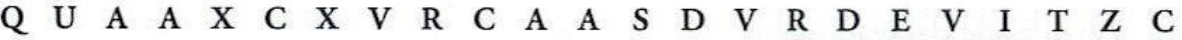
$\begin{array}{llllllllllllllllllllllll}P & A & R & A & Q & U & E & C & F & G & F & S & J & D & G & F & K & I & L & A & A & E & B\end{array}$

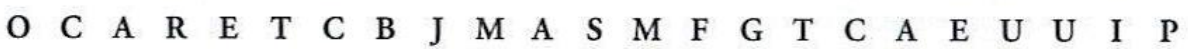
$\begin{array}{lllllllllllllllllllllll}R & S & C & F & T & Y & H & G & Z & E & T & I & T & J & O & P & L & G & D & E & T & E & A\end{array}$

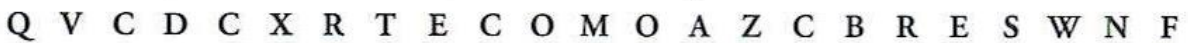

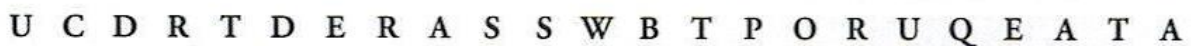

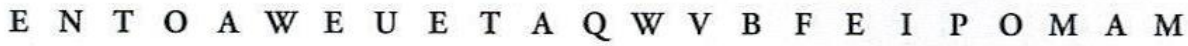

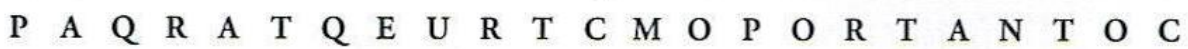

\section{Eu amo você, Língua Portuguesa}

José Luís Landeira e João Henrique Mateos

Às vezes me sinto feliz e expresso minha felicidade ao seu lado, companheira amiga, mistério que estou sempre descobrindo. A felicidade tem corpo e cor e pulsa no meu coraçáo e corre a se encontrar com você, (1) ___ _ a felicidade vira palavra e eu sofro um pouco (2) não sei qual a melhor palavra para expressar o que sinto... Alegria? Contentamento? Entusiasmo?

Certos momentos, você sabe, inunda-me uma tristeza sem fim. Mar cheio de ondas, covas profundas de dor e melancolia, então eu olho ao redor e vejo-me tão só, tâo só que nem palavras tenho. (3) até nessa angústia completa sinto a necessidade de que você esteja por perto. É a primeira coisa que procuro: nomear a minha dor. 
Em outro momento estou inventivo e encontro mil planos para melhorar o mundo, para fazer a vida dos outros mais feliz, para resolver todos os problemas, (4) todos se sintam mais completos e verdadeiros. Nessas horas, também você está em mim e eu mergulho nas suas entranhas e tento levá-la, a sua riqueza, até o outro que me escuta. Às vezes é tão difícil!

Faltam exércitos de grandes pensadores, (5) existem na língua inglesa ou francesa. Faltam muitos poetas, filósofos, sábios, cientistas pensando em português. Expressar raciocínios mais elaborados em português é um verdadeiro desafio. É preciso ter paciência... Você é um diamante, que vai ganhando brilho na lapidaçāo de sua história. História de amor, que você faz com os que aprenderam a amar o seu idioma nas dificuldades de quem você é e de quem nós somos.

(6) eu amo e amar é dizer que se ama e eu amo em português. Não consigo me imaginar dizendo I love you para o ser amado e isso ter o mesmo gosto, a mesma sensaçāo boa de amor que é dizer, mesmo com erro gramatical: "Eu te amo, (7) você é o meu amor!”. E é isso que digo agora, minha língua máe, em que aprendi a ser quem sou: eu te amo, você é o meu amor.

\section{A leitura para construir a argumentaçáo}

\section{Discussáo oral}

1. Recapitulem oralmente: o que você lembra sobre a obra Vidas secas, de Graciliano Ramos, trabalhada na Situação de Aprendizagem anterior?

2. Qual é a funçáo social de um poema, isto é, por que as pessoas leem poesia?

\section{Leitura e Análise de Texto}

Ao ler o poema a seguir, procure identificar a crítica presente nele. Observe, por exemplo, como pode ficar caro, em termos humanos, um momento aparentemente tão simples e prazeroso como tomar um café de manhā.

\section{O açúcar}

O branco açúcar que adoçará meu café nesta manhā de Ipanema nāo foi produzido por mim nem surgiu dentro do açucareiro por [milagre. 
Vejo-o puro

e afável ao paladar

como beijo de moça, água

na pele, flor

que se dissolve na boca. Mas este açúcar

năo foi feito por mim.

Este açúcar veio

da mercearia da esquina e tampouco o fez

dono da mercearia.

[o Oliveira,

Este açúcar veio

de uma usina de açúcar em Pernambuco

ou no Estado do Rio

e tampouco o fez o dono da usina.

Este açúcar era cana

e veio dos canaviais extensos

que não nascem por acaso

no regaço do vale.
Em lugares distantes, onde não há hospital nem escola,

homens que não sabem ler e morrem de

aos 27 anos

[fome

plantaram e colheram a cana

que viraria açúcar.

Em usinas escuras,

homens de vida amarga

e dura

produziram este açúcar

branco e puro

com que adoço meu café esta manhã em

[Ipanema.

GULLAR, Ferreira. Toda poesia. Rio de Janeiro: José Olympio, 2006.

1. No caderno, escreva as ideias do poema que considerou mais importantes.

2. No primeiro verso, Ferreira Gullar usa o adjetivo branco antes do substantivo açúcar: "O branco açúcar que adoçará meu café". O poeta, entretanto, poderia ter formulado esse verso da forma mais comum, sem o adjetivo. Ao usar o termo branco, o poema reforça um valor:

a) biológico, destacando a necessidade do açúcar para uma boa saúde.

b) afetivo, atribuindo-lhe inocência e luminosidade.

c) intelectual, caracterizando o açúcar que, sendo um substantivo, deve aparecer sempre com um adjetivo.

d) histórico, observando sua importância no mundo globalizado e consumista.

3. Observe:

Em usinas escuras,

homens de vida amarga

e dura

produziram este açúcar

branco e puro

com que adoço meu café esta manhã em Ipanema 
$\mathrm{O}$ branco muitas vezes está associado à pureza e à inocência. $\mathrm{O}$ gesto de adoçar o café parece inocente e sofisticado, ainda mais se pensarmos que é realizado numa bela manhã no bairro elegante de Ipanema, no Rio de Janeiro.

Explique, no caderno, como a antítese escuras/branco, presente no poema, reforça uma visáo crítica da sociedade.

\section{Discussão oral}

- O que é trabalho escravo nos dias de hoje?

\section{APRENDENDO A APRENDER}

Conheça melhor o autor da obra: Ferreira Gullar nasceu no dia 10 de setembro de 1930, na cidade de São Luís, capital do Maranháo, quarto filho dos 11 que teriam seus pais. É considerado um dos nomes mais importantes da poesia brasileira contemporânea. Sua obra é marcada pelo olhar crítico à sociedade, preocupado principalmente com as injustiças sociais.

1. No caderno, elabore um poema que revele seu olhar crítico a respeito de alguma injustiça social. Siga de perto o estilo de Ferreira Gullar, poeta contemporâneo que também fez de sua obra de arte um instrumento para transformar o mundo.

2. Ao ler o próximo texto, pense no poema de Ferreira Gullar, que acabamos de examinar, e relacione os dois textos.

\section{O que é trabalho escravo}

\section{$[\ldots]$}

Muitas vezes, quando peóes reclamam das condiçóes ou querem deixar a fazenda, capatazes armados os fazem mudar de ideia. "A água parecia suco de abacaxi, de táo suja, grossa e cheia de bichos." Mateus, natural do Piauí, e seus companheiros usavam essa água para beber, lavar roupa e tomar banho. [...] "Sempre que vejo um trabalhador cego ou mutilado pergunto quanto o patrāo lhe pagou pelo dano e eles têm me respondido assim: 'Um olho perdido, R\$60,00. Uma máo perdida, R\$100,00’. E assim por diante. Estranho é que o corpo com partes perdidas tem preço, mas se a perda for total náo vale nada", afirma um integrante da equipe de fiscalização do Ministério do Trabalho e Emprego.

Repórter Bnasil. Agência de Noticias. Disponivel em: <http://www.reporterbrasil.org.br/conteudo.phpłid=4́. Acesso em: 20 nov, 2009. 


\section{Produzindo seu projeto}

Após a leitura dos textos $O$ açúcar e $O$ que é trabalho escravo, elabore um projeto de texto argumentativo. Lembre-se dos passos dados por Pedro em exercício anterior. A seguir, preencha o quadro. O professor irá verificá-lo. Guarde-o, pois futuramente você irá usá-lo para construir seu texto.

\begin{tabular}{|c|c|}
\hline \multicolumn{2}{|c|}{ Projeto de texto argumentativo } \\
\hline Tema central & Exploraçáo do trabalhador \\
\hline Tese & \\
\hline Termos que vou definir no texto & \\
\hline Argumento menos importante (1) & \\
\hline Argumento médio (2) & \\
\hline Argumento mais importante (3) & \\
\hline
\end{tabular}

\section{LIÇÃO DE CASA}

Procure no livro didático o que ele diz sobre o que é argumentação e texto dissertativo. Liste no caderno as frases que julgar importantes nas definiçōes lidas. Compare-as com as anotaçóes feitas nas atividades de $A$ leitura para construir a argumentaçáo e faça uma lista definitiva, retirando e adaptando as ideias que achar inconsistentes.

\section{VOCÊ APRENDEU?}

Sérgio, seu colega da classe vizinha, inscreveu-se para fazer o Enem (Exame Nacional do Ensino Médio). Ele está apreensivo por achar que não conseguirá fazer a redaçáo e pediu sua ajuda nessa questáo. O que você o aconselharia a fazer?

\section{SITUAÇÃO DE APRENDIZAGEM 3 UMA MANHÃ ESPECIAL NA VIDA DE MAIKON}

Conheça Maikon, um rapaz de 18 anos que está procurando emprego.

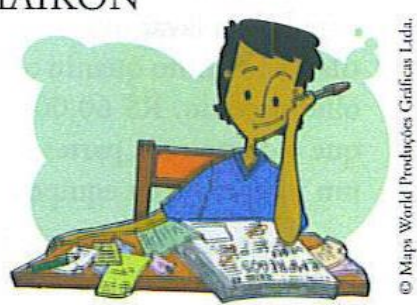

ANEXO D - "Momento de escrita: a redação de acesso ao ensino superior" ( $C A$, Vol. 2, 3롤 série $E M)$ 
2. Depois de compreender essas explicaçōes, Maikon se sentiu triste e deprimido. Ficou com vontade de desistir de tudo. Achou que nunca chegaria a lugar algum, sentiu-se indigno. Discuta, em classe, as razóes e a validade dessa atitude. A seguir, no caderno, escreva-lhe um SMS (um torpedo), via celular, animando Maikon a melhorar, identificando aspectos em que isso poderá, de fato, ser feito. Considere que seu celular dispóe apenas de 160 caracteres (incluindo espaços e sinais de pontuaçăo) por mensagem.

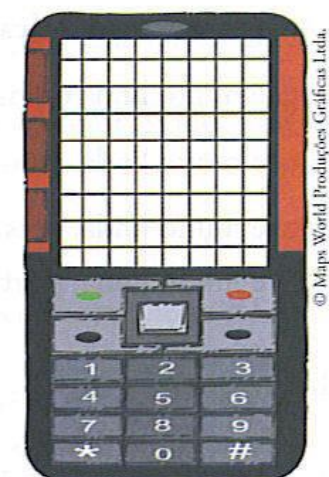

Traga para a próxima aula questôes de vestibular encontradas em sites, no livro didático e em outros livros disponíveis na biblioteca ou na sala de leitura da escola que tratem de conteúdos discutidos nas últimas aulas. Certifique-se de também trazer as respostas.

\section{Produção escrita}

Assuma, mais uma vez, o papel de Maikon e escreva um recado no site de relacionamento para a namorada dele, Paula, explicando o ocorrido na seleçáo de emprego. Explique-lhe os problemas de escrita e deixe claro o seu empenho em aplicar-se mais na próxima vez.

\section{VOCÊ APRENDEU?}

Elabore, no caderno, um resumo dos conteúdos que considerou mais significativos nesta Situação de Aprendizagem.

20 SITUAÇÃO DE APRENDIZAGEM 4

MOMENTO DE ESCRITA: A REDAÇÃO DE ACESSO AO ENSINO SUPERIOR

\section{Colhendo informaçóes}

\section{APRENDENDO A APRENDER}

O gênero dissertaçáo escolar: nesta Situação de Aprendizagem, vamos desenvolver um gênero textual argumentativo comum em exames e concursos - a dissertação escolar. 
Ela é comumente pedida em vestibulares e processos seletivos de emprego. Trata-se de um gênero textual argumentativo, assim como o artigo de opiniáo ou a resenha.

1. Com base no projeto de texto argumentativo que você fez na Situaçăo de Aprendizagem 2, reflita:

a) No que você teve mais dificuldades?

b) O que você propóe para que essas dificuldades sejam superadas em um próximo projeto de texto?

2. No Brasil, ainda existe o problema do trabalho infantil? Em que regióes você acha que esse problema é mais corrente?

3. Leia o texto a seguir:

\section{Trabalho infantil no Brasil}

Há 5,438 milhóes de crianças e adolescentes entre 5 e 17 anos que trabalham no país.

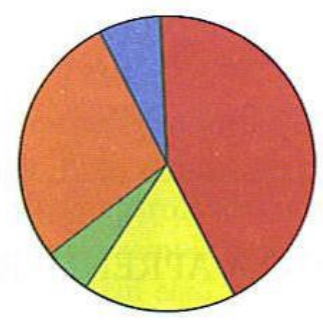

Nordeste $42,2 \%$ (2,296 milhōes)

Sudeste $27,82 \%$ (1,513 milhão)

$\square$ Sul $17,25 \%$ (938 mil)

Centro-Oeste $7,02 \%$ (382 mil)

Norte $5,25 \%$ (285 mil)

Fonte: IBGE/PNAD, 2001.

Responda no caderno:

a) Em que regiáo o percentual de crianças trabalhadoras é mais alto? Em que regiáo o percentual é mais baixo? Forme uma frase comparativa usando o conectivo enquanto.

b) Reescreva a frase a seguir, substituindo o verbo haver por existir.

Há 5,438 milhöes de crianças e adolescentes entre 5 e 17 anos que trabalham no pais.

Junte as oraçōes a seguir dando-lhes o sentido pedido entre parênteses. Inicie a frase de acordo com a sugestáo. Siga o modelo: 
(contradiçāo)

Passou por todos os processos avaliativos com sucesso.

Năo conseguiu o cargo de diretora.

Inicie com: Passou por todos os processos avaliativos com sucesso, mas (ou porém, entretanto) náo conseguiu o cargo de diretora.

a) (tempo)

O mundo terá menos injustiças sociais.

A sociedade vive livre de preconceitos.

Inicie com: Quando a sociedade...

b) (causa)

Havia feito o exame escrito.

Não precisou passar pela prova prática.

Inicie com: Náo precisou...

c) (condiçāo)

Você decide ir ao cinema.

Eu vou com você.

Inicie com: Se você...

\section{APRENDENDO A APRENDER}

Leia jornais sempre que possível. Os textos jornalísticos váo ajudá-lo a compreender melhor os diferentes assuntos que irá estudar na escola.

\section{Discussão oral}

a) Você considera um problema grave o fato de haver trabalho infantil no Brasil? Por quê?

b) Na sua opiniáo, quais são as causas da exploração do trabalho infantil em nosso país?

\section{Leitura e Análise de Texto}

\section{A crueldade do trabalho infantil}

A crueldade do trabalho infantil é um pecado social grave em nosso país. A dignidade de milhóes de crianças brasileiras está sendo roubada diante do desrespeito aos direitos 
humanos fundamentais que não lhes são reconhecidos: por culpa do poder público, quando náo arua de forma prioritária e efetiva, e por culpa da família e da sociedade, quando se omitem diante do problema ou quando simplesmente o ignoram em decorrência da postura individualista que caracteriza os regimes sociais e políticos do capitalismo contemporâneo, sem pátria e sem conteúdo ético.

MEDEIROS NETO, Xisto T. de. A crueldade do trabalho infantil. Diário de Natal. 21 out. 2000.

1. Transcreva do texto para o caderno:

a) $\mathrm{O}$ argumento que o enunciador usa para mostrar que "A crueldade do trabalho infantil é um pecado social grave em nosso país".

b) As causas apresentadas para justificar esse argumento.

2. Comente em classe a seguinte frase: Você acredita que o ditado popular "O trabalho dignifica o homem" também serve para as crianças?

\section{APRENDENDO A APRENDER}

O senso comum é um conjunto de crenças consideradas verdadeiras em uma determinada sociedade, mesmo que nāo o sejam. Essas crenças são entendidas como pertencentes a toda a humanidade, mesmo que apenas compartilhadas por uma comunidade. Acreditar que misturar leite e manga pode matar é um exemplo de senso comum. Por vezes, o senso comum transforma uma verdade particular em algo universal, como quando se diz que todos os políticos são desonestos ou que os brasileiros são muito acolhedores. $\mathrm{O}$ uso do senso comum empobrece o texto argumentativo e dificulta a construçáo de ideias lógicas.

3. Verifique o próximo texto.

Submetidas aos constrangimentos da miséria e da falta de alternativas de integraçáo social, as famílias optam por preservar a integridade moral dos filhos, incutindo-lhes valores, tais como a dignidade, a honestidade e a honra do trabalhador. Há um investimento no caráter moralizador e disciplinador do trabalho, como tentativa de evitar que os filhos se incorporem aos grupos de jovens marginais e delinquentes, ameaça que parece estar cada vez mais próxima das portas das casas.

MARIN, J. O. B. O trabalho infantil na agricultura moderna. Goiània: Revisza UFG, v. 7, n² 01, jun. 2004.

Quando se fala dos motivos pelos quais a família também é culpada pela exploraçáo do trabalho infantil, o texto apresenta um argumento considerado senso comum. Identifique-o. 


\section{Discussão oral}

Qual é a necessidade de termos leis?

4. Leia este texto:

Art. $4^{\circ}-$ É dever da família, da comunidade, da sociedade em geral e do Poder Público assegurar, com absoluta prioridade, a efetivaçáo dos direitos referentes à vida, à saúde, à alimentação, à educaçáo, ao esporte, ao lazer, à profissionalizaçăo, à cultura, à dignidade, ao respeito, à liberdade e à convivência familiar e comunitária.

BRASIL. Estatuto da Criança e do Adolescente. Lei n 8.069, de 13 de julho de 1990

O artigo $4^{\circ}$ do Estatuto da Criança e do Adolescente é respeitado na sua comunidade? Justifique sua resposta.

\section{Discussáo oral}

- Qual é o tema central, em comum, de todos os textos que examinamos até agora nesta Situação de Aprendizagem?

- Como eles evidenciam contradiçōes entre ideal e realidade?

- Qual é o perigo de examinarmos o assunto apenas a partir do senso comum?

\section{LIÇĀO DE CASA}

Encontre no livro didático, em jornais ou revistas três frases que revelem o senso comum sobre determinado problema. Anote-as e apresente à classe na próxima anla. Explique, no caderno, por que considera que elas revelam senso comum.

\section{Preparando o caminho para o texto}

1. Com base nas ideias presentes nos textos anteriores, prepare um projeto de texto sobre o seguinte tema: $O$ trabalho infantil na realidade brasileira. Anote, no caderno, as seguintes informaçôes sobre seu projeto de texto dissertativo: (a) tema central; (b) tese; (c) termos que vai definir no texto; (d) argumento principal; (e) argumento secundário; (f) argumento terciário; (g) exemplo(s) que comprove $(\mathrm{m})$ os argumentos; $(\mathrm{h})$ outras ideias importantes.

2. Uma vez feito o projeto, responda às seguintes perguntas no caderno, formando uma frase completa para cada uma delas: 
a) Primeiro parágrafo - introduçāo

- Do que vai tratar essa redaçáo? (Que tese vai ser defendida?)

- Por que este tema é importante?

b) Segundo parágrafo - argumento mais fraco

- Qual o argumento menos convincente de que disponho?

- Como ele se relaciona com o tema e com a tese?

- Existe algum modo de exemplificar esse argumento? Qual?

c) Terceiro parágrafo - argumento intermediário

- Qual o argumento intermediário de que disponho?

- Como ele se relaciona com o tema e com a tese?

- Existe algum modo de exemplificar esse argumento? Qual?

d) Quarto parágrafo - argumento mais forte

- Qual o argumento mais convincente de que disponho?

- Como ele se relaciona com o tema e com a tese?

- Existe algum modo de exemplificar esse argumento? Qual?

- Que relaçóes existem entre esse argumento e os dois anteriores?

e) Último parágrafo - conclusăo

- Uma síntese de minhas ideias até o presente momento.

- Que soluçáo proponho para esse problema do trabalho infantil?

- Como essa solução se relaciona com a realidade?

1. No caderno, reescreva essas oraçóes em ordem direta, ou seja, respeitando a ordem sujeitoverbo-complementos ou predicativos, sem, entretanto, mudar seu sentido:

a) Com razão, os homens desejam a paz.

b) Viram as crianças, entusiasmadas, os pássaros.

c) Às segundas, terças e sextas de manhā, estudo Língua Portuguesa.

d) Viveu Ronaldo, durante toda sua vida, experiências excepcionais.

\section{Produzindo a dissertação escolar}

1. Com o projeto de texto pronto e as questóes respondidas, é o momento de redigir sua dissertaçáo escolar, gênero textual muito comum em vestibulares e outros exames de acesso ao Ensino Superior, tais como o Enem. Ele deve seguir os seguintes critérios:

- ser escrito na modalidade padráo da língua portuguesa;

- náo ser escrito em forma de poema (versos) ou narraçáo;

- ter, no mínimo, 15 (quinze) linhas escritas. 


\section{APRENDENDO A APRENDER}

Ao desenvolver o tema proposto, procure utilizar os conhecimentos adquiridos e as reflexóes feitas ao longo de sua formaçāo. Selecione, organize e relacione argumentos, fatos e opinióes para defender seu ponto de vista e suas propostas sem ferir os direitos humanos.

2. Antes de entregar seu texto ao professor, troque-o com um colega para obter contribuiçóes que possam melhorá-lo.

Entre os critérios utilizados para corrigir seu texto, o professor verificará se você:

a) demonstrou domínio da norma-padrāo da língua escrita;

b) compreendeu a proposta de redaçāo e aplicou conceitos das diferentes áreas do conhecimento para desenvolver o tema, dentro dos limites estruturais do texto dissertativo-argumentativo;

c) selecionou, relacionou, organizou e interpretou informaçóes, fatos, opiniôes e argumentos em defesa de um ponto de vista;

d) demonstrou conhecimentos dos mecanismos linguísticos necessários para a construção da argumentaçāo;

e) elaborou proposta de soluçáo para o problema abordado, demostrando respeito aos valores humanos e considerando a diversidade sociocultural.

3. Após a elaboração do texto, considere os seguintes critérios para avaliar seu trabalho: (1) compreensão da proposta de redação; (2) seleção e organização de informaçóes, fatos e opiniōes; (3) tese adequada e original; (4) argumentos eficientes; (5) comprovação adequada dos argumentos; (6) exemplos eficientes; (7) conclusão eficiente; (8) se a proposta de soluçāo para o problema abordado respeita os valores humanos e considera a diversidade sociocultural; (9) uso adequado da norma-padrão da língua portuguesa.

4. Depois de corrigido, o texto lhe será devolvido. Compare o ponto de vista do professor com o seu. Discuta em classe aspectos da escrita em que todos os alunos devem melhorar. Reescreva seu texto seguindo as orientaçóes dadas e devolva-o para a correçáo final, com a primeira versáo. Observe que náo se trata de escrever um outro texto, mas de aprimorar o que você já fez.

\section{VOCÊ APRENDEU?}

Responda às seguintes questóes no caderno:

1. O que você mais gostou de estudar? Por quê?

2. O que considerou desinteressante nesta Situaçāo de Aprendizagem? Por quê?

3. Explique com suas palavras o que é argumentar. 


\section{ANEXO E - "As vozes do outro e a nossa na resenha" (Caderno do Professor, Vol. 3, $1^{\text {a }}$ série $\left.E M\right)$}

aparência estética agradável aos conteúdos. Usualmente, a folha do fôlder é dobrada em duas ou três partes.

Leve para a aula alguns fôlderes, tomando o cuidado de emprestar pelo menos um a cada grupo.

Cada grupo terá de produzir um, apresentando ao público a proposta da sua instalação. Coletivamente, a classe discutirá o nome da exposição dos trabalhos, bem como se haverá o uso de algum logotipo especial. Os fôlderes poderão ser feitos à mão ou impressos conforme as possibilidades da escola. Tome o cuidado, no entanto, de fazer a leitura atenta dos textos produzidos pelos alunos antes de aprová-los para qualquer divulgação na escola ou na comunidade; caso, é claro, a classe deseje promover a exposição.

O fôlder deve terminar com as seguintes informações, como o exemplo a seguir:

Nome da exposição: Nove instalações produzidas pela $1^{\text {a }}$ série do Ensino Médio. Curadoria: nome do professor. Onde: nome da escola, espaço usado e endereço. Quando: data e horários da exposição.

\section{Para você, professor!}

É importante que a escrita do fôlder, coletiva, reflita o conhecimento que a classe adquiriu durante esta Situação de Aprendizagem. Avise seus alunos que haverá, ainda, outras atividades que tomarão a exposição como base, mesmo depois que ela terminar. Estamos já vislumbrando a próxima Situação de Aprendizagem.

\section{Atividade 7}

Elabore, com os alunos, a exposição. Consulte seu coordenador sobre a possibilidade de utilizar todo o espaço da escola para as instalações. Recomendamos que, na medida do possível, elas fiquem expostas pelo menos por um dia inteiro, sendo ideal que o tempo se prolongue por alguns dias, como costuma ocorrer com outras exposições fora do espaço escolar.

Durante a exposição, solicite aos alunos que façam um resumo individual detalhado do evento, que será usado na próxima Situação de Aprendizagem. O professor precisa apenas dar um visto nessa atividade e devolvê-la oportunamente aos alunos.

\section{SITUAÇÃO DE APRENDIZAGEM 4 AS VOZES DO OUTRO E A NOSSA NA RESENHA}

Há gêneros em que a voz do outro se apresenta com especificidades próprias que desafiam as habilidades de leitura e escrita. Um desses textos é a resenha. Nesse momento, vamos estudar o processo de construção do gênero textual resenha e aplicar o conceito desenvolvido na exposição realizada na Situação de Aprendizagem anterior. 
Tempo previsto: 6 a 8 aulas.

Conteúdos e temas: elaboração da resenha.

Competências e habilidades: elaborar resenha crítica; posicionar-se criticamente sobre os valores sociais expressos nas manifestações culturais e artísticas; utilizar os conhecimentos sobre a relação arte e realidade para analisar formas de organização de mundo, de textos e de identidades, emitindo juízos de valor.

Estratégias: atividades individuais e em grupo; apresentação do professor de forma dialogada com os alunos; recapitulação da Situação de Aprendizagem anterior.

Recursos: texto apresentado neste Caderno; resenhas de jornais e revistas.

Avaliação: avaliação processual acompanhando o desenvolvimento dos alunos na compreensão do conceito; elaboração de resenha; processo de revisão e autocorreção.

\section{Sondagem}

Discuta em classe o que os alunos acharam da exposição. Peça-lhes que fundamentem suas opiniões. Reforce bem a ideia de que não basta dizer "eu acho", que é importante explicar bem por que se pensa dessa forma. Incentive os alunos a superar a tendência de elogiar ou criticar apenas repetindo chavões. Peça-lhes que se esforcem em pensar o que ainda ninguém pensou.

Anote na lousa as opiniões mais bem fundamentadas e peça aos alunos que também as anotem no caderno. Observe a capacidade de argumentação da turma. Identifique aqueles que apresentam maior habilidade e os que necessitam de atenção especial.

\section{Roteiro para aplicação da Situação de Aprendizagem 4}

\section{- Elaboração da resenha}

Estratégias de leitura da resenha e elementos caracterizadores do gênero textual. Produção de resenha a partir de situação específica.

\section{Atividade 1}

Apresente a seus alunos a resenha a seguir. Antes, contudo, pense em como utilizar o texto para desenvolver as habilidades de leitura. De modo geral, a leitura exige cinco movimentos básicos:

1. Reconhecer o objetivo da leitura que se fará Isso significa encontrar um objetivo para a leitura do texto.

2. Formular previsões e antecipações sobre o texto antes de começar a lê-lo e durante o processo de leitura.

3. Interagir adequadamente aspectos materiais (como tamanho das letras, cor e textura do papel etc.), linguísticos (tais como vocabulário e estruturas morfossintáticas), enciclopédicos (o conhecimento de mundo) e contextuais (onde e como foi produzido o texto e onde e como será lido).

4. Avaliar as previsões feitas com o que se vai conhecendo do texto. Avaliar as expectativas e (re)formular novas hipóteses.

5. Formular uma opinião sobre o que se leu. 
Para esse fim, proponha a seguinte questão inicial: por que o autor do texto recomenda o show de Marcia Castro?
Enquanto ouve as possíveis respostas, mostre interesse em saber qual o conceito de seus alunos sobre um bom espetáculo.

\section{Marcia Castro combina arte e boa diversão}

Cantora ganha a plateia pela inteligência mesmo com repertório pouco conhecido

Crítica: Lauro Lisboa Garcia

Marcia Castro já deixou claro no álbum de estreia, Pecadinho, que se faz de porta-voz da irreverência. Não é à toa que sintoniza com as estripulias sonoras do outsider Tom Zé, um de seus ídolos e coautor, com Tuzé de Abreu, do Frevo (Pecadinho), que abre o CD e encerra o show em cartaz no Teatro Crowne Plaza. No palco, ela aplica seu aprendizado em teatro musical, como se atuasse em esquetes cômicos de cabaré. Tem algo da ironia de Cida Moreira e do deboche de Silvia Machete, mas é como se aspirasse também a integrar a galeria de Aracy de Almeida, Maria Alcina e Cássia Eller, com estágio em Angela Ro Ro, mas sem rancor.

No show de estreia, entre goles de água e de outra bebida que o copo de plástico branco ocultava, a cantora baiana foi subindo a temperatura a cada música, até que quando chegou na hilária Vergonha (Luciano Salvador Bahia), não se sabia se ela estava fazendo tipo, com a voz empastada, por causa do personagem bebum da canção, ou se realmente estava "em águas", como se diz na Bahia. De qualquer maneira, esse combustível contribuiu para a performance.

As canções, mesmo as mais sérias como Medo (J. Velloso), Em Nome de Deus (Sérgio Sampaio) e Coração selvagem (Belchior), não escapam da flecha do ceticismo. Quando escancara no humor, como em Futebol para principiantes (Kleber Albuquerque), Barraqueira (Manuela Rodrigues) e Você gosta (Tom Zé), é pândega. Como Tom Zé, ela compensa certas insuficiências vocais buscando soluções no canto falado, na interpretação vigorosa. O efeito de seus "pecadinhos" é imediato: mesmo com repertório praticamente desconhecido, ganha a plateia em cada canção, bulindo com a inteligência e a sexualidade, evidenciando cada letra esperta.

Os músicos que a acompanham no palco - guitarra, teclado, bateria, trompete e baixo - não são os mesmos do CD, mas afinam com as características do projeto. Tanto são aptos a romper em experimentalismo, provocando estranhamento logo de início, como caem no samba de Roque Ferreira (Barulho) e no rock de Chico Buarque (Jorge Maravilha), com desenvoltura. É uma prazerosa combinação de diversão, arte e ousadia, que anda fazendo falta por aí.

\section{Serviço}

Marcia Castro. Teatro Crowne Plaza (153 lugares). Rua Frei Caneca, 1360. 3a , 21 horas. R\$ 20. Até $25 / 3$

GARCIA, Lauro Lisboa. Marcia Castro combina arte e boa diversão. O Estado de S. Paulo. Disponível em <http://www.estado.com.br/editorias/2008/03/10/cad-1.93.2.20080310.13.1.xml>. Acesso em: 18 jun. 2009. 
Após a leitura, peça-lhes que identifiquem:

1. O nome do artista.

\section{Marcia Castro.}

2. O local, a hora e o dia da apresentação.

Teatro Crowne Plaza, terça-feira, às 21 horas.

3. O ponto de vista do enunciador do texto sobre o show.

Muito positivo, o enunciador recomenda o show.

4. Um trecho do texto em que o enunciador apresenta um pequeno resumo do show.

Qualquer um-ou mais - dos trechos a seguir:

"[...] álbum de estreia, Pecadinho [...] Tom $Z \dot{e}, u m$ de seus ídolos e coautor, com Tuzé de Abreu, do Frevo (Pecadinho), que abre o CD e encerra o show em cartaz no Teatro Crowne Plaza. [...] No show de estreia, entre goles de água e de outra bebida que o copo de plástico branco ocultava, a cantora baiana foi subindo a temperatura a cada música, até que quando chegou na hilária Vergonha (Luciano Salvador Bahia) não se sabia se ela estava fazendo tipo, com a voz empastada, por causa do personagem bebum da canção, ou se realmente estava 'em águas', como se diz na Bahia. [...] Os músicos que a acompanham no palco - guitarra, teclado, bateria, trompete e baixo - não são os mesmos do CD".

5. Outro trecho do texto em que se apresente uma opinião do enunciador (Lauro Lisboa Garcia).

Qualquer um-ou mais - dos trechos a seguir: "[...] se faz de porta-voz da irreverência. [...] No palco, ela aplica seu aprendizado em teatro musical, como se atuasse em esquetes cômicos de cabaré. Tem algo da ironia de Cida Moreira e do deboche de Silvia Machete, mas é como se aspirasse também a integrar a galeria de Aracy de Almeida, Maria Alcina e Cássia Eller, com estágio em Angela Ro Ro, mas sem rancor. [...] As canções, mesmo as mais sérias [...] não escapam da flecha do ceticismo. Quando escancara no humor, [...] é pândega. Como Tom Zé, ela compensa certas insuficiências vocais buscando soluções no canto falado, na interpretação vigorosa. O efeito de seus 'pecadinhos' é imediato: mesmo com repertório praticamente desconhecido, ganha a plateia em cada canção, bulindo com a inteligência e a sexualidade, evidenciando cada letra esperta. [...] É uma prazerosa combinação de diversão, arte e ousadia, que anda fazendo falta por ai".

6. A finalidade do texto no cotidiano da sociedade.

A finalidade do texto no cotidiano da sociedade: possibilitar que os leitores tenham uma clara ideia do show, bem como que conheçam a opinião do crítico.

\section{Para você, professor!}

O texto apresenta termos e referências musicais que não são do conhecimento imediato do aluno. Observe que, para realizar essa atividade, o aluno não precisa conhecer todos os termos que aparecem no texto. Observe também que as perguntas 1 a 5 remetem a partes específicas do texto lido. Já a questão 6 obriga a levantar hipóteses. Certifique-se de que seus alunos notem que se trata de um texto que circula nos jornais. 


\section{Atividade 2}

Em certo momento do texto, o enunciador afirma:

"De qualquer maneira, esse combustível contribuiu para a performance."

Promova uma discussão para que os alunos expressem suas opiniões sobre o texto. Os argumentos devem ser claros e inteligíveis sobre o fato de o texto incentivar o alcoolismo ou não.

Proponha que substituam adequadamente o termo de origem inglesa performance por outro da língua portuguesa.

Desempenho.

\section{Para você, professor!}

Professor, aproveite essa oportunidade para discutir o valor formador da imprensa na sociedade. Questione seus alunos para que eles formulem suas opiniões, fundamentadas tanto sobre a responsabilidade da imprensa como sobre os limites desta, que são, exatamente, os da responsabilidade do leitor em ler ou não o texto.

Discutam também a respeito da influência da língua inglesa no uso cotidiano da linguagem.

\section{Atividade 3}

Utilizando como base as atividades anteriores, explique o gênero textual resenha.

O que é uma resenha?

Trata-se de uma sintese que expressa a opinião do resenhista sobre determinado fato cultural: um livro, um filme, um jogo de futebol, uma peça de teatro, uma exposição, uma novela, um show, um conto etc. O objetivo da resenha é orientar o leitor pela enorme quantidade de produção cultural que aumenta cada dia e, por vezes, confunde. A opinião apresentada, devidamente argumentada, pode ser favorável ou não ao fato cultural analisado.

Embora seja um resumo, a resenha deve ir direto ao ponto, concentrando-se em provar, dentro do texto resenhado, a opinião do resenhista. Isso resulta em uma mistura, no corpo do texto, de alguns momentos de pura descrição com outros em que se faz uma crítica fundamentada. O objetivo é equilibrar, na qualidade do texto, essas duas dimensões: resumo e opinião pessoal.

Vale destacar que a resenha não é um texto superficial: deve apresentar as principais características do fato cultural, mas sem esquecer de argumentar os pontos de vista e sem cansar o leitor com palavras em excesso.

Recomende a seus alunos que evitem (SEMPRE!) expressões como "eu acho", "não gostei", bem como gírias, que demonstram falta de familiaridade com o texto resenhado.

Além disso, em uma resenha devem aparecer o título, a referência da obra resenhada e o resumo ou a síntese do conteúdo contemplado pela avaliação crítica.

Não se esqueça de que uma resenha é um texto argumentativo, ou seja, deve ter um ponto de vista.

Comente as diferenças entre "resenha sobre um show" " "notícia sobre um show". Utilize as definições fornecidas neste Caderno sobre resenha para contrastá-las com o gênero entrevista e determinar suas diferenças e semelhanças. 


\section{Atividade 4}

Peça a seus alunos que elaborem uma resenha sobre a exposição das instalações que realizaram na Situação de Aprendizagem anterior.

Para você, professor!

Seria importante que a exposição, se possivel, ainda estivesse sendo apresentada quando pedir esta atividade. De qualquer maneira, agora é o momento de devolver os resumos anteriormente feitos, por ocasião da visita à exposição, para que sirvam de base para a elaboração das resenhas.

Apresente a seus alunos os seguintes critérios que serão utilizados na correção da atividade.

\section{Critérios de correção da resenha}

1. Presença dos elementos que compõem o gênero resenha.

2. Uso da norma-padrão da língua portuguesa, especialmente do verbo.

3. Veracidade das informações apresentadas e respeito aos direitos humanos.

4. Pertinência das opiniões apresentadas.

\section{Aprofundando conhecimentos}

"Um projeto de texto [...] é um gênero textual que substitui, em uma redação escolar, o famoso rascunho. Ele permite que o seu texto não seja um fluir de 'achismos', mas um conjunto de argumentos encadeados que se apresenta ao leitor como produto de uma reflexão."

LANDEIRA, J. L.; BARONTO, L. E. O espaço em gêneros. São Paulo: Salesiana. 2009.
Em um primeiro momento, os grupos deverão fazer seu projeto de texto e entregá-lo ao professor.

Ao corrigir os trabalhos, mantenha o foco nesses quatro eleméntos. Forneça sugestões para deixar os trabalhos melhores apenas no que diz respeito aos critérios solicitados. Devolva os trabalhos aos grupos e peça-lhes que escrevam o texto solicitado, seguindo o projeto que elaboraram, bem como as orientações dadas. Observe que não se trata de redigir um texto novo, mas de limitar-se ao projeto, melhorando-o no que foi solicitado. Explique que não devem tirar do texto as partes problemáticas (o que o deixaria, provavelmente, pior), mas que devem resolvê-las. Nas anotações, não deixe de fazer elogios sinceros, quando apropriado, ao trabalho realizado, mas não diretamente ao aluno.

O projeto de texto retorna ao professor junto com o texto produzido, para que sejam verificados os progressos que resultaram de suas anotações.

\section{Expectativas de aprendizagem e grade de avaliação}

O término do $3^{\circ}$ bimestre é também o momento em que os alunos começam a se dar conta de que o ano letivo está quase chegando ao fim. Trata-se de uma oportunidade para compreender, com os alunos, o percurso feito, procurando fazer os ajustes necessários para que o $4^{\circ}$ bimestre tenha êxito.

É importante, nesse momento, separar as habilidades e os conteúdos de desenvolvimento específicos do $3^{\circ}$ bimestre dos que se projetam ao longo de todo o ano letivo e avaliar os progressos em cada um deles.

Nesse sentido, algumas habilidades se destacam como imprescindíveis: as relacionadas à elaboração de estratégias de leitura e de produção 
de textos, em particular literários e argumentativos. Neste bimestre lidamos com grande variedade de gêneros textuais: entrevistas, contos, peças de teatro, poemas, fôlderes, resenhas, além, é claro, da instalação, que pode ser considerada um texto não verbal.

Nesse momento, devemos ter bem claro que um bimestre é um período curto para encontrar avanços significativos na maioria dos alunos, mas o fato de estarmos no $3^{\circ}$ bimestre significa que temos um bom tempo de material lido e produzido pelos alunos para avaliar. Sugerimos, então, que compare uma ou duas atividades do $1^{\circ}$ bimestre produzidas pelo aluno com uma realizada agora, avaliando assim os aspectos em que ele progrediu e aqueles em que não se notaram avanços. Observe se o aluno:

1. constrói devidamente a textualidade;

2. elabora um projeto de texto.

Embora trabalhosa, tal prática permitirá que acompanhemos mais conscienciosamente o desenvolvimento das habilidades em médio e longo prazo. No que diz respeito à leitura, observe o comportamento do aluno diante do texto. Surgem então algumas questões.

1. Como o aluno se relaciona com o título: ignora-o ou incorpora-o ao processo de elaboração de sentido?

2. Como o gênero textual orienta as expectativas de leitura geradas?

3. Consegue organizar as informações lidas em sínteses? Consegue utilizá-las em outras Situações de Aprendizagem?

4. Reconhece a intencionalidade comunicativa dos textos? Leva em conta tal intencionalidade ao realizar sua leitura?

O aluno teve oportunidade, durante o 3 o bimestre, de entrar em contato com as respostas a essas questões. Cabe agora observar se tais respostas foram introjetadas, construindo o cidadão autônomo que desejamos ver.

A concatenação de ideias, tanto em uma entrevista como em um conto, em diferentes níveis de construção coesiva do texto, foi o carro-chefe no desenvolvimento das habilidades de leitura e escrita.

Durante o bimestre, aprofundamos o conhecimento da entrevista e das relações estabelecidas entre perguntas e respostas. Além disso, estudamos o verbo com base em uma perspectiva estilística que desejamos ver traduzida em uma atitude de respeito ao uso da palavra na produção textual. Isso é extremamente importante em uma sociedade que cultiva a perspectiva de que não importa o como se diz, desde que sejamos entendidos. Muitas confusões seriam desfeitas se as pessoas desenvolvessem a habilidade de "pesar" as palavras antes de usá-las.

Consideramos também a literatura como realidade intersemiótica, complexa, em que a linguagem hipercarregada de sentido apresenta-se ao leitor como um desafio em que se misturam a construção da cultura com o prazer de ler. Novamente se destaca o fato de que a língua é viva e de que a pior armadilha em que podemos cair é desconsiderar seu valor em mover-nos para a frente, rumo a um futuro melhor... ou para trás. Os gêneros textuais literários conversam entre si, estabelecendo, tanto no próprio texto como no leitor, produtivas relações intertextuais.

Outro conteúdo essencial para o desenvolvimento de habilidades de leitura e escrita com autoria e autonomia é a resenha. Nesse gênero, acrescentamos, à capacidade de síntese desenvolvida nos bimestres anteriores, a habilidade de argumentar satisfatoriamente uma opinião. 
ANEXO F - "O que faz de alguém um escritor?" ( $C P$, Vol. 1, 2ª série EM)

Para finalizar a atividade', peça que os alunos, em duplas ou trios, escrevam um final para a peça, levando em conta aspectos da época e do lugar. Recolha as atividades que serão usadas em momento posterior.

\section{Critérios atitudinais}

Durante a execução da atividade em sala de aula, observe se o aluno:

$\checkmark$ usa o dicionário e outros compêndios de estudo, tais como gramáticas, para dirimir dúvidas sobre o uso da norma-padrão.

$\checkmark$ mantém-se concentrado na execução da atividade, evitando perturbar ou distrair colegas.

$\checkmark$ é respeitoso ao lidar com os colegas e com o professor.

\section{Critérios de correção} texto:

Ao corrigir a atividade, leve em conta se o

$\triangleright$ tem aproximadamente 20 linhas.

D apresenta boa organização e clareza das ideias.

$\checkmark$ mantém-se próximo ao estilo de Martins Pena, manifestando crítica social.

$\triangleright$ apresenta letra legível.
Para você, professor!

É importante que o aluno tenha conhecimento dos critérios pelos quais seu trabalho será avaliado antes mesmo de começá-lo. É recomendável apresentar à classe esses critérios por escrito.
Aprofundando conhecimentos

"A comunicação é a ponte que integra subjetividades através de ferramentas de linguagem - os signos, as técnicas e as tecnologias comunicativas. Os discursos construídos pela linguagem referem-se ao mundo real traduzido pelas individualidades que o experimentam, mas transformam-se, uma vez expressos, em modelos que orientam futuras percepções do real. Aderem às coisas como parte integrante delas, adquirindo concretude quase da mesma natureza."

COSTA, Cristina. Fiç̧ão, comunicaşão e mídias. São Paulo: Senac, 2002.

\section{SITUAÇÃO DE APRENDIZAGEM 2 O QUE FAZ DE ALGUÉM UM ESCRITOR?}

Escrever não é uma tarefa fácil e também não é um dom para seres superiores e inspirados por entidades divinas. Qualquer um pode escrever bons textos se devidamente orientado. Claro, desde que haja empenho. Esta atividade tem por objetivo motivar o aluno para a escrita significativa em textos argumentativos, em particular, artigos de opinião. Trata-se de gêneros complexos que facilitam a transição entre o universo escolar e extraescolar.

\footnotetext{
${ }^{1}$ Atividade adaptada de: LANDEIRA, J. L. Quando as palavras resolvem fazer arte. In: MURRIE, Z. F. (Coord,). Linguagens, códigos e suas tecnologias: livro do estudante: Ensino Médio. Brasilia: MEC/nep, 2002. p. 89-95.
} 
Tempo previsto: 6 a 9 aulas.

Conteúdos e temas: conceito e definição de argumentação; texto argumentativo: artigo de opinião; conectores: conjunções.

Competências e habilidades: distinguir enunciados objetivos e enunciados subjetivos; reconhecer as linguagens como elementos integradores de comunicação.

Estratégias: aula interativa, com a participação dialógica do aluno, com a preparação e conhecimento de conteúdos e estratégias por parte do professor; uso de recursos audiovisuais; valorizaçào do cotidiano escolar e de um aprendizado ativo centrado no fazer.

Recursos: livro didático; dicionário de Língua Portuguesa; filmes; textos de livros extraclasse; mural da escola; comunicados escolares; música.

Avaliação: resolução de exercícios; elaboração de artigo de opinião.

\section{Sondagem}

Verifique com seus alunos as diferenças entre "textos informativos" e "textos de opinião". Isso permitirá que você avalie o que eles já sabem sobre o assunto a ser estudado. Para isso sugerimos o seguinte exercício:

Os trechos a seguir foram retirados de jornais. Indique quais são parte de uma notícia (ou reportagem) e quais são parte de um artigo de opinião:

\section{Trecho 1}

“(...) O Brasil precisa de agricultura livre de transgênicos para suprir o mercado interno com alimentos saudáveis e baratos e, depois, vender aos ricos mercados da Europa, Japão e China, que rejeitam OGMs. Eles pagam até $10 \%$ a mais para se ver livres do milho 'frankenstein'. A soja certificada como não-transgênica recebe dos europeus prêmio de até 8 dólares por tonelada (....."

LONDRES, Flávia. Revista Caros Amigos, ago. 2001.

\section{Trecho 2}

"(...) A discussão em torno da possível criação de uma zona livre da plantação de grãos transgênicos nos Estados do Paraná e de Santa Catarina causou reação do governo do Rio Grande do Sul. Enquanto paranaenses e catarinenses analisam supostas vantagens econômicas com a produção de alimentos sem modificação genética, gaúchos apostam que os produtores irão rejeitar determinações contrárias à libertação do cultivo de sementes transgênicas (...)."

"PR e SC discutem criar 'zona livre'; RS reage" de Mari Tortato, Léo Gerchmann e Jairo Marques, Folha de S.Paulo, 2 out. 2003, fornecido pela Folhapress.

\section{Trecho 3}

(...) Na última safra, mais de $80 \%$ da soja plantada no Estado (RS) foi transgênica. Os agricultores gaúchos esperam a decisão do governo para saber se poderão utilizar sementes do organismo modificado geneticamente para a próxima safra ou não. 
Publicamente, já disseram que, mesmo que sem permissão, pretendem repetir o uso (...)."

Da sucursal de Brasilia, Folha de S.Paulo, 18 set. 2004.

\section{Para você, professor!}

É sempre bom lembrar que nosso objetivo, neste momento, é resgatar as ideias da turma a respeito dos conteúdos que serão tratados, estimulando-os para o aprendizado.

Os Trechos 1 e 2 são artigos de opinião e o Trecho 3 é uma notícia. A questão que está sendo discutida é a produção de alimentos transgênicos

Justifique sua resposta à questão anterior dizendo por que definiu os textos como notícia ou como artigo de opinião.

Identifique nos trechos de opinião qual questão está sendo discutida e qual a posição do autor em relação a ela.

\section{Roteiro para aplicação da Situação de Aprendizagem 2}

$\checkmark$ Conceito e definição de argumentação

Conceituar a argumentação, considerando alguns aspectos de seu caráter dialógico e das condições próprias da situação comunicativa concreta (a enunciação).

\section{Texto argumentativo: artigo de opinião}

Conceituar o gênero argumentativo "artigo de opinião" valorizando as relações entre esse gênero e o mundo do trabalho.

Conectores: conjunções

Usar de modo reflexivo os conectores, especialmente, as conjunções, na produção de um texto argumentativo.

\section{Atividade 1}

Inicialmente, vamos definir o que são enunciados que transmitem fatos e enunciados que transmitem opiniões.

Escreva na lousa as seguintes frases:

I. A Terra é um planeta do sistema solar.

II. O rap é uma música de mau gosto.

Qual a diferença entre os dois enunciados?

A estrutura sintática é a mesma:

Sujeito + verbo de ligação + predicativo do sujeito

No entanto, a Frase I afirma uma verdade científica que, considerando o que sabemos sobre nosso sistema solar até hoje, não será contestada. Nem sequer há necessidade de argumentar a favor ou contra. Trata-se de um fato. Ninguém vai perguntar: "Por que você pensa assim?".

Já a Frase II manifesta uma opinião. A expressão "de mau gosto" pode ser contestada por pessoas que tenham posições diferentes nesse assunto. Não será difícil encontrar quem pergunte: "Por que você pensa assim?". Para sustentar a Frase II é necessário argumentar.

Naturalmente, com o passar do tempo, uma opinião pode passar a ser considerada um fato. É o que ocorreu, por exemplo, com a ideia de a Terra ter forma semelhante a uma esfera: originalmente tal ideia foi tida como absurda por alguns, hoje considerada um fato inquestionável.

$\triangleright$ O que é argumentar?

"Argumentar é mais do que simplesmente dar a opinião sobre algo - é sustentá-la com 
argumentos, que são razões, evidências, provas, dados etc. que dão suporte à ideia defendida".

BARBOSA, J. P. Sequência didática: artigo de opinião. São Paulo: Secretaria de Estado da Educação de São Paulo, s/d.

\section{Aprofundando conhecimentos}

"Pois toda a argumentação visa à adesão dos espíritos e, por isso mesmo, pressupõe a existência de um contato intelectual."

PERELMAN, C.; OLBRECHSTS-TYTECA, L. Tratado da argumentação: a nova retórica. Trad. Maria Ermantinca G. G. Pereira. São Paulo: Martins Fontes, 1996

A argumentação produz textos dissertativos (também chamados de dissertativo-argumentativos):

"Em um texto dissertativo, o objetivo do autor é mostrar para seus leitores que ele tem razão em pensar daquela maneira."

ABAURRE, M. L. M. A vida em uma sociedade letrada. In: MURRIE, Z. F. (Coord.). Linguagens, códigos e suas tecnologias: livro do estudante: Ensino Médio. Brasilia: MEC/Inep, 2002. p. 95-97.

\section{Atividade 2}

O passo seguinte é estudar como isso se realiza em um texto. Inicialmente, examine em classe o trecho a seguir:

\section{A redação e o vestibular}

A redação nos chamados grandes vestibulares não é bem o que se apregoa no
Ensino Médio. Para atender ao que Unicamp, Unesp e USP, por exemplo, pedem a seus futuros alunos, o candidato deve conseguir superar o modelo oferecido pela maioria dos colégios e cursinhos.

Uma redação que siga uma estrutura muito divulgada de introdução, com resumo do assunto abordado, desenvolvimento genérico do tema proposto e conclusão retomando a introdução, consegue no máximo uma nota mediana. Muitas redações mal pontuadas escondem o triste paradoxo de o candidato acreditar que havia feito um bom trabalho.

LANDEIRA, J. L. A redação e o vestibular. In: Folha de S.Paulo, 17 fev. 2004. Disponivel em: <http://www. folha.uol.com.br/folha/sinapse/ult1063u739.shtml>. Acesso em: 30 out. 2007.

Pergunte à classe qual o assunto tratado e a opinião do autor a respeito. Solicite que escrevam essa opinião em uma frase.

Para você, professor!

O texto tem como assunto a redação do vestibular. $\mathrm{O}$ autor defende a opinião de que o que se ensina sobre redações na maioria das instituições educacionais não prepara o aluno para o processo seletivo.

Uma boa argumentação exige que se discuta uma questão controversa ou polêmica.

O que é uma questão controversa? Neste nosso estudo, chamamos de questão controversa, questão polêmica ou tese $a$ afirmação cuja resposta não seja única, permitindo, então, que se assumam diferentes posicionamentos. 


\section{Para você, professor?}

Os termos "discutir" e "criticar" costumam ter um sentido negativo no senso comum: como se fossem sinônimos de "brigar" e "falar mal", respectivamente. Nada mais longe da realidade disso em nossa disciplina, em que procuramos um diálogo constante, mas devidamente fundamentado. Ou seja, não apenas no "achismo", mas nas relações que as ideias estabelecem entre si.

Se eu disser "A água é importante para a vida humana", não temos uma questão controversa, pois ninguém, com alguma medida de boa saúde mental, vai questionar essa afirmação. No entanto, se eu disser que "o trabalho infantil desrespeita os direitos da criança", algumas pessoas concordarão; outras discordarão. Trata-se, certamente, de uma questão controversa.

As questões controversas podem tanto ser de caráter particular como geral. A decisão entre "ficar" com um(a) menino(a) ou não é uma questão particular e não seria matéria para um artigo de opinião. Entretanto, questões sobre política, assuntos científicos, sociais e culturais são de interesse geral, visto que afetam, de uma forma ou de outra, grande número de pessoas direta ou indiretamente.

Além disso, não podemos confundir questão polêmica (ou tese) com assunto. Quando falo "o aborto" ou "as drogas" não tenho uma questão polêmica, mas um assunto. Sobre aborto e drogas eu posso ter as mais diferentes questões polêmicas. Por exemplo:

$\checkmark$ o aborto é um crime.

$\triangleright$ o aborto é uma solução.

$\triangleright$ as drogas prejudicam a saúde humana.

$\downarrow$ as drogas prejudicam a economia de um país.

\section{Atividade 3}

Realize com seus alunos o exercício proposto a seguir ${ }^{2}$ :

Leia atentamente os trechos a seguir e identifique a questão controversa subjacente.

\section{Trecho I}

Prevenir é um grande trunfo para vencer mais algumas batalhas contra a Aids; no entanto isso muitas vezes é ofuscado pelo desejo e esperança que cercam a busca pela cura: a pesquisa científica, a vacina, o avanço no desenvolvimento de medicamentos e a melhoria na assistência, que apresenta um caráter de maior urgência e de resultados imediatos. Assim, de maneira geral, a prevenção acaba ocupando uma posição secundária dentro das políticas de saúde voltadas à Aids, sendo abordada em ações pontuais e isoladas e desarticuladas entre si, que não resultam em mudanças de impacto e sustentáveis.

José Carlos Veloso/Gapa - Grupo de apoio à prevenção à Aids-Gapa: BR/SP <http://www,gapabrsp.org.br> Agência Carta Maior, 18 set. 2004.

A prevenção à Aids recebe tratamento secundário em relação à busca de sua cura.

\section{Trecho II}

O que me espanta é que os jovens se queixem de que têm poucas fontes de conhecimento da sexualidade. Só nas últimas décadas, as escolas começaram a introduzir o tema nas salas de aula, assim mesmo com ênfase na higiene corporal, tendo em vista as DSTs. A familia, aos poucos, começa a derrubar tabus, exceto nas classes populares, onde a falta de conhecimento obriga os jovens a aprenderem 2Exercício extraido de BARBOSA, J. P. Sequéncia didática: artigo de opinião. São Paulo: Secretaria de Estado da Educação de
São Paulo, s/d. 
"na rua", como se dizia na minha geração. Hoje, "aprende-se" na televisão. Primeiro, com a exacerbação do voyeurismo, tipo Big Brother. É o bordel despejado, via eletrônica, no quarto das crianças ou na sala da casa. Sem que familias, escolas e igrejas cuidem da educação do olhar de crianças e jovens.

FREI BETTO, Revista Caros Amigos, edição n 87

Hoje em dia, os jovens não têm poucas fontes de conhecimento sobre a sexualidade.

\section{Trecho III}

As empresas de motoboys estavam a mil, cada motoqueiro ganhava um salário que compensava o risco, assim como também foram os lotações. Agora vai começar o cadastramento, o controle, e a verdade é que o Estado está organizado para não deixar que a elite perca poder econômico e político, estão todos preparados para boicotar qualquer tentativa de crescimento da classe tida por eles como mais baixa, que na real somos nós.

FERRĖZ, Revista Caros Amigos, edição n² 86

$O$ cadastramento dos motoboys apenas favorece a elite.

\section{Atividade 4}

Continue, com seus alunos, examinando o texto $A$ redação e o vestibular.

\section{(...)}

Antes de tudo, o perfil que as consideradas grandes universidades procuram é o do aluno que tenha algo a dizer. Por exemplo, o tema deste ano da Fuvest, o tempo, exigia uma abstração ao mesmo tempo científica, sociológica e filosófica, que não é comum na escola brasileira e não faz parte do cardápio usual dos cursinhos.

Sobre um tema como o tempo, muitos conseguiriam, nesse último vestibular, citar conceitos de sala de aula como "o tempo é relativo" ou "o passado explica o presente". Contudo é reduzido o número dos que justificariam razoavelmente tais teses fugindo de clichês mal formulados, como "se Hitler tivesse estudado o passado, não teria repetido o erro de Napoleão, ao invadir a Rússia no inverno". Poucos pensariam na possibilidade de Hitler dispor de um armamento superior ao que Napoleão utilizara um século antes. A questão poderia ser não de desconhecimento histórico, mas de orgulho e crença na tecnologia da época.

LANDEIRA, J. L. A redação e o vestibular. In: Folha de S. Paulo, 17 fev. 2004. Disponivel em: <http://wwwl. folha.uol.com.br/folha/sinapse/ult 1063u 739.shtml> Acesso em: 30 out. 2007.

Apresente as seguintes questões:

Qual o argumento que sustenta a opinião do autor apresentada na introdução do artigo $A$ redação e o vestibular?

$\checkmark$ Que exemplo ele fornece de seu argumento?

$O$ autor defende que o perfil procurado pelas grandes instituições de Ensino Superior é o de alguém que tem algo a dizer e não alguém preparado mecanicamente para escrever. Como exemplo ele cita o tema da Fuvest de 2004, o tempo, sobre o qual muitos conseguiriam apenas citar clichês de sala de aula como "o tempo é relativo" ou "o passado explica o presente".

\section{Atividade 5}

A leitura de um texto exige do leitor certo grau de autonomia, o que inclui a necessidade de elaborar uma meta de leitura como um plano de ação. Agora que os alunos encontraram 
a questão controversa em trechos de artigos de opinião, ofereça-lhes um artigo completo sobre o qual eles responderão às seguintes perguntas:

1. Qual a questão controversa que está sendo discutida no artigo?

2. Quais os argumentos que o autor utiliza para defender sua opinião?

3. O texto elabora uma proposta de intervenção solidária, respeitando os valores humanos?

Apresente essas perguntas antes da leitura do texto. Elas funcionarão como um plano de ação que se traduzirá em meta de leitura.

Você poderá obter artigos de opinião em jornais e revistas e até na internet. O livro didático adotado possivelmente traz artigos de opinião.

Discuta com seus alunos, antes da leitura do texto, o título e as expectativas geradas. Isso reforçará o fato de que o título deve levantar horizontes de expectativas no leitor e que as diferentes partes do texto devem funcionar como um todo. Trata-se de uma simples e eficiente estratégia de leitura.

\section{Passagem pela adolescência}

"Filho criado, trabalho redobrado." Esse conhecido ditado popular ganha sentido quando chega a adolescência. Nessa fase, o filho já não precisa dos cuidados que os pais dedicam à criança, tão dependente. Mas, por outro lado, o que ele ganha de liberdade para viver a própria vida resulta em diversas e sérias preocupações aos pais. Temos a tendência a considerar a adolescência mais problemática para os pais do que para os filhos. É que, como eles já gozam de liberdade para sair, festejar e comemorar sempre que possível com colegas e amigos de mesma idade e estão sempre prontos a isso, parece que a vida deles é uma eterna festa. Mas vamos com calma porque não é bem assim.

Se a vida com os filhos adolescentes, que alguns teimam em considerar um fato aborrecedor, é complexa e delicada, a vida deles também o é. Na verdade, o fenômeno da adolescência, principalmente no mundo contemporâneo, é bem mais complicado de ser vivido pelos próprios jovens do que por seus pais. Vejamos dois motivos importantes.

Em primeiro lugar, deixar de ser criança é se defrontar com inúmeros problemas da vida que, antes, pareciam não existir: eles permaneciam camuflados ou ignorados porque eram da responsabilidade só dos pais. Hoje, esse quadro é mais agudo ainda, já que muitos pais escolheram tutelar integralmente a vida dos filhos por muito mais tempo.

Quando o filho, ainda na infância, enfrenta dissabores na convivência com colegas ou pena para construir relações na escola, quando se afasta das dificuldades que surgem na vida escolar - sua primeira e exclusiva responsabilidade -, quando se envolve em conflitos, comete erros, não dá conta do recado etc., os pais logo se colocam em cena. Dessa forma, poupam o filho de enfrentar seus problemas no presente, é claro, mas também passam a ideia de que eles não existem por muito mais tempo.

É bom lembrar que a escola - no ciclo fundamental - deveria ser a primeira grande batalha da vida que o filho teria de enfrentar sozinho, apenas com seus recursos, como experiência de aprender a se conhecer, a viver em comunidade e a usar seu potencial com disciplina para dar conta de dar os passos com suas próprias pernas.

Em segundo lugar, o contexto sociocultural globalizado atual, com ideais como consumo, felicidade e juventude eterna, por exemplo, compromete de largada o processo de amadurecimento típico da adolescência, que exige certa dose de solidão para a estruturação de tantas vivências e, principalmente, interlocução. E com quem os adolescentes contam para conversar?

Eles precisam, nessa época de passagem para a vida adulta, de pessoas dispostas a assumir o lugar da maturidade e da experiência com olhar crítico sobre as questões existenciais e da vida em sociedade 
para estabelecer com eles um diálogo interrogador. Várias pesquisas já mostraram que os jovens dão grande valor aos pais e aos professores em suas vidas. Entretanto, parece que estamos muito mais comprometidos com a juventude do que eles mesmos.

Quem leva a sério questões importantes para eles em temas como política, sexualidade, drogas, ética, depressão e suicídio, vida em familia, vida escolar, violência, relações amorosas e fidelidade, racismo, trabalho etc.? Quando digo levar a sério me refiro a considerar o que eles dizem e dialogar com propriedade, e não com moralismo ou com excesso de jovialidade. E, desse mal, padecem muitos pais e professores que com eles convivem.

Os adolescentes não consegüem desfrutar da solidão necessária nessa época da vida, mas parece que se encontram sozinhos na aventura de aprender a se tornarem adultos. Bem que merecem nossa companhia, não?

SAYÃO, Rosely. Passagem pela adolescencia. Folha de S. Paulo, São Paulo, 21 fev. 2008. Caderno Equilibrio, p. 12.

\section{Para você, professor!}

$\mathrm{O}$ assunto do texto é a adolescência. A autora defende que todo adolescente está sozinho na aventura de se tornar adulto. Os argumentos são dois: 1) "Deixar de ser criança é se defrontar com inúmeros problemas da vida que, antes, pareciam não existir" e 2) "o contexto sociocultural globalizado atual (...) compromete de largada o processo de amadurecimento típico da adolescência". A autora propõe, como resposta, "pessoas dispostas a assumir o lugar da maturidade e da experiência com olhar crítico sobre as questões da vida em sociedade para estabelecer com eles um diálogo interrogador".

\section{Atividade 6}

Agora proponha que seus alunos, em duplas, produzam um artigo de opinião. $\mathrm{Na}$ verdade, será uma primeira versão. Em outro momento do bimestre, esse artigo será devolvido e avaliado pelos alunos em uma atividade que desenvolverá a autoavaliação. Proponha dois temas polêmicos e atuais na comunidade, sobre os quais os alunos conseguem se expressar com propriedade.

\section{Critérios atitudinais}

Durante a execução da atividade em sala de aula, observe se o aluno:

Usa o dicionário e outros compêndios de estudo, tais como gramáticas, para dirimir dúvidas sobre o uso da norma-padrão.

$\checkmark$ Mantém-se concentrado na execução da atividade, evitando perturbar ou distrair colegas.

$\checkmark$ É respeitoso ao lidar com os colegas e com o professor.

\section{Critérios de correção}

Ao corrigir a atividade, leve em conta se o texto:

$\checkmark$ tem aproximadamente 30 linhas.

$\triangleright$ defende uma questão controversa por meio de argumentos.

$\triangleright$ apresenta boa organização e clareza das ideias.

$\triangleright$ apresenta letra legivel.

Para você, professor!

É importante que o aluno tenha conhecimento dos critérios pelos quais seu trabalho será avaliado antes mesmo de começá-lo. É recomendável apresentar à classe esses critérios por escrito. 


\section{Atividade 7}

Rebeca é uma aluna que raramente faz as lições com atenção. Ela termina correndo para tentar sair mais cedo da classe. Um dia, fez a lição rapidinho. Contudo, a reação da professora não foi a esperada. Qual das duas frases vai ser usada por Rebeca para contar o que aconteceu?

I. Terminei a lição mais cedo, portanto a professora não me deixou sair antes de a aula acabar.

II. Terminei a lição mais cedo, mas a professora não me deixou sair antes de a aula acabar.

Chamamos de conectores as palavras ou expressões que conectam partes do texto entre si, possibilitando a construção do sentido do texto. Estabelecem relações como:

$\checkmark$ oposição (mas, porém, etc.);

$\checkmark$ causalidade (pois, porque, etc.);

$\triangleright$ temporalidade (quando, etc.);

$\checkmark$ consequência (por isso, então, etc.);

$\checkmark$ condição (se, caso, etc.);

$\triangleright$ finalidade (a fim de que, para, etc.).

Uma boa gramática ou, possivelmente, seu livro didático, deve fornecer uma lista exaustiva dos principais conectores. É importante não "jogar" tudo para o aluno, apenas desejamos que ele construa o conceito do que é um conector e pare para refletir sobre as relações que essas estruturas estabelecem entre os termos dos enunciados.

\section{Para você, professor!}

As conexões estão presentes em todos os gêneros discursivos, orais ou escritos, mas elas se materializam das mais diferentes formas. Na explicação, utilize-se de algum slogan publicitário ou do trecho de uma letra de música do momento para ampliar os horizontes de sua explicação.

Lembre-se de que o objetivo não é que ele decore uma lista de conectores, mas que compreenda as relações que esses conectores estabelecem entre as diferentes partes do texto.

A continuidade do texto envolve a progressão daquilo que se diz. Ao escrever um texto argumentativo, não podemos apenas "encher" linhas, mas procuramos defender uma questão controversa por meio de argumentos já selecionados. A continuidade de sentidos, um constante ir e vir entre aquilo que já é sabido pelo leitor e aquilo que ele virá a saber, exige a articulação entre as diferentes partes do texto por meio do uso adequado de conectivos.

\section{Atividade 8} guir:

Faça com seus alunos o exercício ${ }^{3}$ a se-

1. Leia com atenção os períodos abaixo e inclua

os organizadores textuais em destaque nas colunas adequadas do quadro a seguir, de acordo com a função que desempenham em cada período.

\footnotetext{
${ }^{3}$ Exercicio extraido de BARBOSA, J. P. Sequência didática: artigo de opinião. São Paulo: Secretaria de Estado da Educação de
São Paulo, s/d.
} 


\begin{tabular}{|l|l|l|l|}
\hline Introduz argumento & $\begin{array}{c}\text { Acrescenta } \\
\text { argumento }\end{array}$ & Introduz conclusão & $\begin{array}{c}\text { Introduz uma ideia na } \\
\text { direção contrária do } \\
\text { que é afirmado antes }\end{array}$ \\
\hline & & & \\
\hline & & & \\
\hline & & & \\
\hline & & & \\
\hline
\end{tabular}

a) Não se pode, de maneira simplista, afirmar que o brasileiro não gosta de ler, pois é preciso considerar que muitos deles ainda hoje não têm acesso a livros e outros tantos nem sequer sabem ler.

b) As músicas eram de mau gosto, o bolo estava seco, a bebida, quente. Em suma, a festa foi um fracasso.

c) O filme não é muito bom. A fotografia é escura demais, o roteiro está cheio de falhas de continuidade. Além disso, os atores trabalham muito mal.

d) A bebida alcoólica diminui a capacidade do homem de responder imediatamente aos estímulos do mundo externo. Portanto, não se deve dirigir alcoolizado.

e) Criar condições de desenvolvimento econômico é o melhor modo de ajudar a população carente. Entretanto, muitos governantes preferem implementar políticas assistencialistas. f) No Egito antigo a cerveja era considerada a bebida nacional. Os egípcios acreditavam que ela apresentava propriedades curativas, especialmente contra picadas de escorpião. A bebida também era utilizada como produto de beleza pelas mulheres, que acreditavam em seus poderes de rejuvenescimento.

g) "A reserva de vagas para estudante de escolas públicas não resolve a questão, como também não assegura que os beneficiados sejam os mais pobres, uma vez que não há na proposta corte por renda. Não é improvável que estudantes menos qualificados de classes mais abastadas migrem para o ensino público visando a beneficiar-se da cota." (Editorial, Folha de S.Paulo, 30 maio 2004).

h) O ambiente era bastante hostil, porém muitos animais sobreviveram lá.

i) O Brasil é uma nação jovem, posto que $42,1 \%$ da população tem menos de 18 anos. 


\begin{tabular}{|l|l|l|l|}
\hline Introduz argumento & $\begin{array}{c}\text { Acrescenta } \\
\text { argumento }\end{array}$ & Introduz conclusão & $\begin{array}{c}\text { Introduz uma ideia na } \\
\text { direç̃o contrária do } \\
\text { que é afirmado antes }\end{array}$ \\
\hline pois & Além disso & Em suma & Entretanto \\
\hline uma vez que & também & Portanto & porém \\
\hline posto que & & & \\
\hline
\end{tabular}

Para você, professor!

Você poderá elaborar exercícios muito simples com conectores a partir de artigos de opinião encontrados em jornais de sua localidade. Nesse caso:

I. Escolha trechos desses artigos e retire os conectores, pedindo para os alunos restabelecerem.

II. Forneça, em quadro à parte, os conectores devidos.

Uma variante pode ser a de oferecer mais conectores do que espaços em branco, de modo que sobrem alguns termos não usados. Tome o cuidado, no entanto, para que esses termos não sejam sinônimos.
Aprofundando conhecimentos

"Ao produzir um discurso, o homem se apropria da língua, não só com o fim de veicular mensagens, mas, principalmente, com o objetivo de atuar, de interagir socialmente, instituindo-se como EU e constituindo, ao mesmo tempo, como interlocutor o outro, que é, por sua vez, constitutivo do próprio EU, por meio do jogo de representações e de imagens recíprocas que entre eles se estabelecem."

KOCH, I. G. V. Argumentação e linguagem. São Paulo: Cortez, 1996. 
Pergunte:

$\triangleright$ No trecho lido de Vidas secas, há predominância de períodos curtos ou longos?

$\checkmark$ Que valor expressivo a extensão dos períodos reforça no texto?

Nesse texto, há um predomínio de periodos curtos, que reproduzem o ritmo do pensamento fragmentado da personagem Fabiano. É como se o leitor estivesse acompanhando o ritmo dos seus pensamentos, que surgem aos pedaços, meio desconexos, sem subordinação das ideias.

\section{Atividade 12}

Depois de explicar o valor estilístico dos períodos curtos em Vidas secas, solicite que resolvam o exercício:

$\checkmark$ Que valores são reforçados no texto pela extensão dos períodos no trecho a seguir de Vidas secas?

Dois ou três alunos devem ler, repetidamente, o texto a seguir em voz alta. Incentive uma atitude adequada durante a leitura, que facilite o tom de voz e a articulação das palavras.

Olhou a catinga amarela, que o poente avermelhava. Se a seca chegasse, não ficaria planta verde. Arrepiou-se. Chegaria, naturalmente. Sempre tinha sido assim, desde que ele se entendera. E antes de se entender, antes de nascer, sucedera o mesmo - anos bons misturados com anos ruins. A desgraça estava em caminho, talvez andasse perto. Nem valia a pena trabalhar.

RAMOS, Graciliano, Vidas secas. Rio de Janeiro: Record. 108 ed. 2008.

Observe que o sentido é o mesmo em toda a obra: acompanhar o ritmo do pensamento fragmentado de Fabiano. É como se o.leitor estivesse caminhando junto aos pensamentos que surgem, na personagem, aos pedaços, meio desconexos, sem uma clara subordinação das ideias.

\section{SITUAC̃̃O DE APRENDIZAGEM 2 ELABORANDO UM PROJETO DE DISSERTAÇÃO}

O objetivo desta Situação de Aprendizagem é ensinar os alunos a elaborar um projeto de texto dissertativo tendo em vista os exames de acesso ao Ensino Superior. Além disso, consideraremos a estrutura do gênero dissertativo-argumentativo e outros elementos de construção da textualidade.

Tempo previsto: 6 a 8 aulas.

Conteúdos e temas: estrutura sintática e construção da tese; texto argumentativo: dissertação escolar; estruturação da atividade escrita: planejamento.

Competências e habilidades: comparar as caracteristicas de diferentes gêneros na apresentação de um mesmo tema; formular opinião adequada sobre determinado fato social; determinar categorias pertinentes para a análise e interpretação do texto literário; inferir o sentido de palavras ou expressões considerando o seu contexto. 
Estratégias: aula interativa, com a participação dialógica dos alunos, com a preparação e conhecimento de conteúdos e estratégias por parte do professor; discussão e sistematização dos temas discutidos,

Recursos: livro didático; dicionário de lingua portuguesa; discussão oral.

Avaliação: produção de projeto de texto dissertativo-argumentativo; resolução de exercícios e situações-problema.

\section{Sondagem}

Pergunte aos alunos quem planeja fazer faculdade para dar continuidade aos seus estudos no futuro imediato, assim que terminar o Ensino Médio, e quem pretende fazer no futuro próximo, dando uma pausa nos estudos. Mostre genuíno interesse em ouvir o que dizem os alunos. Queira saber que cursos pretendem fazer e por quê. Pergunte sobre onde pretendem estudar e por quê.

Pergunte-lhes também se têm medo do vestibular. E do Enem?

Ao final, explique que esta Situação de Aprendizagem tem como foco principal os exames de acesso ao Ensino Superior.

\section{Roteiro para aplicação da Situação de Aprendizagem 2}

\section{$\triangleright$ Estrutura sintática e a construção da tese} tática.

Conceituar tese a partir de sua estrutura sin-

$\triangleright$ Texto argumentativo: dissertação escolar

Estudar as características do texto dissertativo escolar visando aos exames de acesso de Ensino Superior:

$\triangleright$ Estruturação da atividade escrita: planejamento
Considerar a importância e o método do planejamento das atividades escritas, em particular do texto dissertativo escolar:

Continuemos tratando dos exames de acesso ao Ensino Superior. Desta vez, nos concentraremos na redação, em particular no texto dissertativo escolar, aquele que é pedido em tais exames.

\section{Atividade 1}

Primeiro, temos de compreender como funciona o processo de realização desse gênero textual. Apresente estes enunciados aos alunos:

Redija uma dissertação, a tinta, desenvolvendo um tema comum aos textos a seguir.

$\checkmark$ (Enem-1998) Com base nas ideias presentes nos textos acima, redija uma dissertação sobre o tema:

$\checkmark$ (Vunesp-2007) Baseando-se em sua experiência, nos textos literários mencionados e nos dois textos jornalísticos transcritos nesta parte, escreva uma redação, no gênero dissertativo, sobre o seguinte tema.

Pergunte: o que há de comum entre esses três enunciados?

Os três enunciados pedem uma dissertação com base em textos lidos anteriormente pelo candidato. 
Elaborar textos dissertativos exige, de partida, dois conhecimentos básicos:

1. conhecer o gênero dissertativo;

2. saber interpretar adequadamente os textos-base.

\section{Atividade 2}

Explique para a classe a seguinte questão: o que é um texto argumentativo.

O que as instituições de Ensino Superior compreendem como "texto argumentativo" é aquele no qual se expõe um tema, defendendo uma ideia central.

Para isso, é necessário ter uma posição definida sobre o assunto tratado, criando uma tese que se defenderá ao longo do texto. Diante de um tema amplo, por exemplo, o trabalho, temos necessidade de fazer um recorte a fim de que nosso texto tenha um objetivo. Não podemos falar tudo sobre o trabalho, temos de escolher sobre o que vamos falar. Então, temos de fazer uma afirmação a respeito desse recorte do tema, e essa afirmação deve provocar polêmica no grupo que desejamos que leia o nosso texto.

Ou seja, dificilmente a afirmação "o trabalho é algo importante" seria uma tese válida de um texto argumentativo, visto que afirmar isso não levantaria polêmica na grande maioria dos leitores de nossa sociedade.

Assim, a partir de certos temas amplos, como os listados a seguir, peça a seus alunos que elaborem possíveis teses para serem desenvolvidas.
$\triangleright$ Violência
$\checkmark$ Aborto
$\checkmark$ Sexo
$\checkmark$ Leitura
$\triangleright$ Política

$\checkmark$ Pena de morte

$\triangleright$ Imprensa

Deixe claro a seus alunos que, para uma afirmação ser polêmica, ela deve permitir a sua negação, ou seja, ela poderá ser negada pelo seu interlocutor. Por esse mesmo motivo é que não podemos considerar a afirmação "A violência das cidades" como uma tese, pois não é possível encontrar a sua negativa. Negando "A violência das cidades", encontramos algo como "a não-violência das cidades", o que não nos permite a construção clara de sentido.

Mas seria uma afirmação válida se disséssemos: "A violência das cidades leva a sérios problemas familiares". A frase pode ser facilmente negada - "A violência das cidades não leva a sérios problemas familiares" - e é suficientemente polêmica em muitos círculos escolares de leitura, espaço onde circula a dissertação escolar, gênero de que estamos tratando.

Recomendamos que as teses sigam a fórmula sintática:

sujeito + verbo + complementos ou predicativos.

$\checkmark$ Complementos: objeto direto, indireto e complementos adverbiais.

$\triangleright$ Predicativos: predicativo do sujeito.

A seguir, temos de desenvolver procedimentos argumentativos.

\section{$\triangleright$ O que é isso?}

São os recursos utilizados por quem escreve visando a que o leitor acredite na tese que o texto está defendendo, sentido-se motivado a fazer o que se propõe.

Um deles é esclarecer o sentido das palavras-chave da tese. Pensemos em "A violência 
das cidades conduz a sérios problemas familiares". As palavras-chave "violência" e "problemas familiares" devem ser esclarecidas.

Sobre "violência", temos que delimitar o seu sentido, para isso, pensemos: o que é violência em nosso texto? Apenas a violência armada na rua? A agressão física familiar também será considerada violência? E o que dizer dos insultos e de outras formas de violência verbal?

A mesma tarefa deve ser desenvolvida para "problemas familiares": Que sentido desejaremos dar a essas palavras no texto? Brigas? Agressão física? Imoralidade? Casos extremos noticiados pela mídia?

Isso tudo deve ficar bem claro para quem vai escrever antes de começar o texto, para que mantenha coerência em todo o desenvolvimento e coesão entre os argumentos apresentados e a tese defendida.

No entanto, o principal procedimento argumentativo é encontrar argumentos que sustentem a tese.

Como encontrar os argumentos? Perguntando "por quê?" para a tese. Por exemplo: "A violência das cidades conduz a sérios problemas familiares." Por quê? As respostas encontradas funcionam como argumentos, que deverão ser desenvolvidos no texto dissertativo solicitado.

A argumentação é um processo textual que exige organização: os argumentos devem se encadear uns nos outros, dando ao leitor a sensação de unidade. Uma excelente ideia pode ser perdida se os argumentos não forem bem organizados ou se forem fracos.

Imaginemos a seguinte tese: $\checkmark$ "A imprensa deve ser responsável ao transmitir informações"

Primeiro, devemos esclarecer o que entendemos por "imprensa" e "transmitir informações", mas principalmente o que entendemos por "responsável". O conceito de responsabilidade muda muito de pessoa para pessoa e precisamos ter bem claro com que sentido usaremos esse termo em nosso texto.

Tendo claro o sentido que essas três palavras-chave assumirão em nosso texto dissertativo, podemos avançar para a etapa seguinte, que é levantar uma série possivel de argumentos. Vale a pena lembrar que um texto dissertativo escolar deve ter entre dois e quatro bons argumentos. Eis alguns exemplos:

As informações da imprensa são o principal instrumento de manutenção da democracia.

$\triangleright$ A sociedade precisa conhecer a verdade dos fatos.

$\checkmark$ Acontecimentos importantes para a nação não podem ser tratados como uma simples distração.

Agora, vamos hierarquizar esses argumentos, ou seja, colocá-los em ordem crescente de importância. $\mathrm{O}$ argumento que consideramos mais importante para defender a nossa tese será o último a ser considerado na elaboração do texto, ele fica sempre para o final. Se, de imediato, apresentarmos o nosso melhor argumento e ele não convencer, de que adiantará oferecer os outros ao leitor? Claro que aquilo que consideramos "melhor argumento" depende de nossa intencionalidade comunicativa: a quem se dirige o texto?

Esquematizando o nosso projeto de texto, temos: 


\begin{tabular}{|l|l|}
\hline \multicolumn{2}{|c|}{ Projeto de texto dissertativo } \\
\hline Tema & Imprensa. \\
\hline Tese & A imprensa deve ser responsável ao transmitir informações. \\
\hline $\begin{array}{l}\text { Termos que vou } \\
\text { definir no texto }\end{array}$ & Imprensa, transmitir informações, responsabilidade. \\
\hline $\begin{array}{l}\text { Argumento menos } \\
\text { importante (1) }\end{array}$ & A sociedade precisa conhecer a verdade dos fatos. \\
\hline $\begin{array}{l}\text { Argumento } \\
\text { (2) }\end{array}$ & $\begin{array}{l}\text { Acontecimentos importantes para a nação não podem ser tratados } \\
\text { como uma simples distração. }\end{array}$ \\
\hline $\begin{array}{l}\text { Argumento mais } \\
\text { importante (3) }\end{array}$ & $\begin{array}{l}\text { As informações da imprensa são o principal instrumento de manuten- } \\
\text { ço da democracia. }\end{array}$ \\
\hline
\end{tabular}

\section{Atividade 3}

Observe que, até agora, não falamos do papel da leitura dos textos para a construção do texto argumentativo. Propomos, no entanto, uma atividade que tome como base alguns textos a fim de que os alunos possam extrair deles o tema e, a partir daí, elaborar um projeto de texto dissertativo. Sugerimos os textos a seguir:

\section{Texto 1}

O açúcar

O branco açúcar que adoçará meu café nesta manhã de Ipanema não foi produzido por mim nem surgiu dentro do açucareiro por [milagre.

$[\ldots]$

Este açúcar veio

da mercearia da esquina e tampouco o fez [o Oliveira, dono da mercearia.

Este açúcar veio

de uma usina de açúcar em Pernambuco ou no Estado do Rio

e tampouco o fez o dono da usina.
Este açúcar era cana e veio dos canaviais extensos que não nascem por acaso no regaço do vale.

[...]

Em usinas escuras,

homens de vida amarga

e dura

produziram este açúcar

branco e puro

com que adoço meu café esta manhã em

[Ipanema.

GULLAR, Ferreira. Toda poesia. Rio de Janeiro: Civilização Brasileira, 1980. p. 227-228.

Para você, professor!

Relacione a proposta textual de Ferreira Gullar com a de Graciliano Ramos: observe que os dois são nomes importantes do que se chama de "literatura engajada", ou seja, aquela que visa a defender um posicionamento político-social de denúncia e de conscientização do leitor. 


\section{Texto 2}

\section{O que é trabalho escravo}

Muitas vezes, quando peões reclamam das condições ou querem deixar a fazenda, capatazes armados os fazem mudar de ideia. "A água parecia suco de abacaxi, de tão suja, grossa e cheia de bichos." Mateus, natural do Piaui, e seus companheiros usavam essa água para beber, lavar roupa e tomar banho. [...] "Sempre que vejo um trabalhador cego ou mutilado pergunto quanto o patrão the pagou pelo dano, e eles têm me respondido assim: 'um olho perdido, RS 60 . Uma mão perdida, RS $100^{\prime}$. E assim por diante. Estranho é que o corpo com partes perdidas tem preço, mas se a perda for total não vale nada", afirma um integrante da equipe de fiscalização do Ministério do Trabalho e Emprego.

Repórter Brasil. Agência de noticias Disponivel em: <http:/www.reporterbrasil.org.br/ conteudo.php?id=4>. Acesso em: 12 fev. 2008.

Discuta os textos em classe e, a seguir, peça aos alunos que, em duplas ou em trios, e em uma folha à parte, para entregar, preencham o esquema a seguir de um projeto de texto dissertativo:

\section{Projeto de texto dissertativo}

\begin{tabular}{|l|l|}
\hline Tema central & \\
\hline Tese & \\
\hline $\begin{array}{l}\text { Termos que vou } \\
\text { definir no texto }\end{array}$ & \\
\hline $\begin{array}{l}\text { Argumento menos } \\
\text { importante (1) }\end{array}$ & \\
\hline $\begin{array}{l}\text { Argumento } \\
\text { (2) }\end{array}$ & \\
\hline $\begin{array}{l}\text { Argumento mais } \\
\text { importante (3) }\end{array}$ & \\
\hline
\end{tabular}

O tema central é a "exploração do trabalhador", os projetos de texto devem respeitar os limites desse tema. Discuta esse tema com seus alunos.
Corrija as atividades e reserve um espaço em uma aula da Situação de Aprendizagem 4 para comentar os resultados, destacando os pontos fortes e identificando aqueles que precisam de maior atenção.

ANEXO H - "Momento de escrita: a redação de acesso ao ensino superior" ( $C P$, Vol. 2, $3^{\text {a }}$ série $\left.E M\right)$ 


\section{SITUAÇÃO DE APRENDIZAGEM 4 \\ MOMENTO DE ESCRITA: A REDAÇÃO DE ACESSO AO ENSINO SUPERIOR}

Os alunos escreverão um texto dissertativo de uma prova do Enem. Para isso, ativarão todos os conhecimentos desenvolvidos até agora neste bimestre. A orientação do professor deve incidir sobre alguns aspectos considerados prioritários, tais como: compreensão dos textos-base, elaboração de projeto de texto, atitude reflexiva na produção textual, revisão do texto produzido, dominio da norma-padrão da língua portuguesa.

Tempo previsto: 6 a 8 aulas.

Conteúdos e temas: estruturação da atividade escrita: planejamento, construção do texto e revisão; texto argumentativo: dissertação escolar de acesso ao Ensino Superior.

Competências e habilidades: propor a reescrita de partes de um texto, utilizando os recursos do sistema de pontuação; formular opinião adequada sobre determinado fato social; desenvolver uma atitude reflexiva na atividade escrita formal.

Estratégias: aula interativa, com a participaçào dialógica do aluno e a preparação e o conhecimento de conteúdos e estratégias por parte do professor; discussão e sistematização dos temas discutidos.

Recursos: livro didático; dicionário de língua portuguesa; discussão oral.

Avaliação: produção de dissertação escolar de acordo com modelo do Enem; resolução de exercícios e situações-problema.

\section{Sondagem}

Discuta em classe o tema do trabalho infantil. $\mathrm{O}$ que os alunos conhecem sobre o assunto? O que pensam a respeito? Ouça atentamente os diversos comentários e desenvolva na sala uma atitude de escuta que estimule o respeito não apenas pela palavra do professor, mas também pelo comentário do colega.

\section{Roteiro para aplicação da Situação de Aprendizagem 4}

$\triangleright$ Estruturação da atividade escrita: planejamento, construção do texto e revisão

Conhecer, estruturar e sintetizar as diferentes partes da atividade escrita argumentativa.

\section{$\triangleright$ Texto argumentativo: dissertação escolar de acesso ao Ensino Superior}

Desenvolver o texto dissertativo-argumentativo visando ao acesso ao Ensino Superior:

\section{Atividade 1}

Comente os pontos fortes do projeto de texto realizado ao final da Situação de Aprendizagem 2. Identifique também os pontos em que houve dificuldades e sugira possibilidades para superá-las. Se possível, identifique páginas do livro didático que tratam especificamente desse tema.

\section{Atividade 2}

A seguir, apresente aos alunos uma proposta de redação do Enem. Ressalte que, antes, eles devem fazer quatro leituras. 
Texto 1

\section{Trabalho infantil no Brasil}

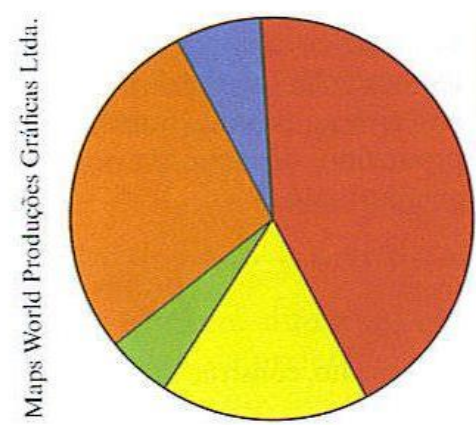

Nordeste $42,2 \%$ (2,296 milhões)

Sudeste $27,82 \%$ ( 1,513 milhão)

Sul $17,25 \%$ (938 mil)

Centro-Oeste $7,02 \%$ (382 mil)

Norte $5,25 \%$ (285 mil)

Há 5,438 milhões de

crianças e adolescentes

entre 5 e 17 anos que

trabalham no país.

Fonte: IBGE/PNAD, 2001.

\section{Texto 2}

\section{A crueldade do trabalho infantil}

A crueldade do trabalho infantil é um pecado social grave em nosso país. A dignidade de milhões de crianças brasileiras está sendo roubada diante do desrespeito aos direitos humanos fundamentais que não lhes são reconhecidos: por culpa do poder público, quando não atua de forma prioritária e efetiva, e por culpa da família e da sociedade, quando se omitem diante do problema ou quando simplesmente o ignoram em decorrência da postura individualista que caracteriza os regimes sociais e políticos do capitalismo contemporâneo, sem pátria e sem conteúdo ético.

\section{Texto 3}

\section{O trabalho infantil na agricultura moderna}

Submetidas aos constrangimentos da miséria e da falta de alternativas de integração social, as famílias optam por preservar a integridade moral dos filhos, incutindo-lhes valores, tais como a dignidade, a honestidade e a honra do trabalhador. Há um investimento no caráter moralizador e disciplinador do trabalho, como tentativa de evitar que os filhos se incorporem aos grupos de jovens marginais e delinquentes, ameaça que parece estar cada vez mais próxima das portas das casas.

MARIN. J. O. B. O trabalho infantil na agricultura moderna. Revista UFG, v.7, $\mathrm{n}^{2} 01$, jun. 2004. 


\section{Texto 4}

Art. $4^{\circ} \dot{E}$ dever da familia, da comunidade, da sociedade em geral e do Poder Público assegurar, com absoluta prioridade, a efetivação dos direitos referentes à vida, à saúde, à alimentação, à educação, ao esporte, ao lazer, à profissionalização, à cultura, à dignidade, ao respeito, à liberdade e à convivência familiar e comunitária.

Estatuto da Criança e do Adolescente. Lei n. 8.069. de 13 de julho de 1990.

Para você, professor!

Os textos podem ser apresentados todos de uma só vez ou um de cada vez, seguidos de uma discussão de seus conteúdos. O importante é que haja um momento de diálogo da classe com os textos-base.

Nessa discussão, não deixe de perguntar:

$\triangleright$ Qual o tema central, em comum, desses textos?

$\triangleright$ Como eles apresentam contradições entre ideal e realidade?

$\triangleright$ Como os textos demonstram que o problema não pode ficar reduzido ao senso comum?

\section{Para você, professor!}

O senso comum é um conjunto de crenças que são consideradas verdadeiras em um determinado grupo social, mesmo que, na maior parte dos casos, não o sejam. Observe que o Texto 3 destaca que o trabalho infantil, para muitos pais, é um modo de incutir valores "tais como a dignidade, a honestidade e a honra do trabalhador", afastando-os de grupos marginais e lutando contra a miséria. Já o Texto 4 apresenta a situação ideal do Estatuto da Criança e do Adolescente, mas que, lamentavelmente, se afasta da realidade de muitas crianças brasileiras.

Finalmente proponha:

Com base nas ideias presentes nos textos. redijam uma dissertação sobre o tema: $\mathrm{O}$ trabalho infantil na realidade brasileira. Esclareça a eles que, ao desenvolver o tema proposto, devem utilizar os conhecimentos adquiridos e as reflexões feitas ao longo de sua formação. Selecionem, organizem e relacionem argumentos, fatos e opiniões para defender seu ponto de vista e suas propostas, sem ferir os direitos humanos.

\section{Observações:}

$\triangleright \mathrm{O}$ texto deve ser escrito na modalidade padrão da língua portuguesa.

$\triangleright$ O texto não deve ser escrito em forma de poema (versos) ou narração.

$\triangleright \mathrm{O}$ texto deve ter, no mínimo, 15 linhas escritas.

Comente com os alunos o enunciado do exercício. Em especial o que significa "modalidade padrão da língua portuguesa" (retome a Situação de Aprendizagem 3, a narrativa do Maikon) e a exigência de não escrever o texto em versos ou narração.

\section{Atividade 3}

Proponha que, antes de tudo, os alunos elaborem um projeto de texto (recapitule a Situação de Aprendizagem 2), conforme o esquema a seguir: 


\begin{tabular}{|l|l|}
\hline \multicolumn{2}{|c|}{ Projeto de texto dissertativo } \\
\hline Tema central & \\
\hline Tese & \\
\hline Termos que vou definir no texto & \\
\hline Argumento principal & \\
\hline Argumento secundário & \\
\hline Argumento terciário & \\
\hline Exemplo(s) que comprove(m) os argumentos & \\
\hline Outras ideias que desejo aproveitar para o texto & \\
\hline
\end{tabular}

\section{Para você, professor!}

Observe que introduzimos dois itens novos em relação ao esquema apresentado na Situação de Aprendizagem 2: "Exemplo(s) que comprove (m) os argumentos" e "Outras ideias que desejo aproveitar para o texto". O objetivo desses itens é que os alunos incorporem ao seu projeto elementos que possam depois aproveitar para a construção do texto dissertativo-argumentativo.

\section{Atividade 4}

Quando o projeto de texto estiver pronto, é hora de redigir, transformar esse projeto no texto dissertativo-argumentativo. Essa passagem exige que se acrescentem exemplos e explicações que acompanhem os argumentos. Além disso, é necessário tomar cuidado na passagem de um argumento para outro e que se façam parágrafos que não se confundam com frases, ou seja, que tenham mais de um período.
Recapitule especialmente o conceito de tese, solicitando que sigam a estrutura sintática que propusemos:

sujeito + verbo + complementos ou predicativos

\section{Aprofundando conhecimentos}

A utilização dos dados tendo em vista a argumentação não pode ser feita sem uma elaboração conceitual que lhes confira um sentido e os torne relevantes para o seguimento do discurso. São os aspectos dessa elaboração - dessa formalização - que fornecem um dos ângulos pelos quais se pode apreender melhor o que distingue uma argumentação de uma demonstração.

PERELMAN, Chaīm; OLBRECHTS-TYTECA, L Tratado da argumentação. Trad. Maria Ermantina Galvão G. Pereira. São Paulo: Martins Fontes, 1996. p. 136 
Afixe na lousa os critérios segundo os quais o texto será corrigido:

a) demonstrar domínio da norma-padrão da língua escrita;

b) compreender a proposta de redação e aplicar conceitos das diferentes áreas do conhecimento para deśenvolver o tema, dentro dos limites estruturais do texto dissertativo-argumentativo;

c) selecionar, relacionar, organizar e interpretar informações, fatos, opiniōes e argumentos em defesa de um ponto de vista;

d) demonstrar conhecimentos dos mecanismos linguísticos necessários para a construção da argumentação;

e) elaborar proposta de solução para o problema abordado, mostrando respeito aos valores humanos e considerando a diversidade sociocultural.

Comente o significado de tais critérios. Relacione o que eles pedem com aquilo que está sendo ensinado e aprendido no curso neste ano letivo.

Para você, professor!

Comente com os alunos que escrever bem não é apenas seguir a norma-padrão da língua portuguesa - embora isso, em textos formais, seja importante. Aplicar conceitos das diferentes áreas do conhecimento para desenvolver o tema significa fazer uso de conhecimentos de outras disciplinas para desenvolver a redação. Para esse tema, História, Geografia e Filosofia certamente têm contribuições importantes que devem ser resgatadas. Além disso, elaborar uma proposta de solução para o problema não significa ser irrealista e jogar toda a responsabilidade para o poder público ou para uma outra entidade superior. Expressões como "O governo deveria acabar com o trabalho infantil" ou "Só Deus pode terminar com esse problema" significam notas baixas na correção.

Não há uma fórmula para fazer um texto dissertativo, mas exploraremos uma possibilidade nesta Situação de Aprendizagem. Acreditamos que este modelo poderá ser a base para outras possibilidades criativas de construção do texto argumentativo. Proponha que, para cada pergunta a seguir, o aluno faça uma frase.

\section{Primeiro parágrafo - introdução}

$\triangleright$ Do que vai tratar esta redação? Que tese será defendida?

$\triangleright$ Por que esse tema é importante?

Segundo parágrafo - argumento mais fraco

Qual é o argumento menos convincente de que disponho?

$\checkmark$ Como ele se relaciona com o tema e com a tese?

$\triangleright$ Existe algum modo de exemplificar esse argumento?

diário

$\triangleright$ Qual é o argumento intermediário de que disponho?

$\checkmark$ Como ele se relaciona com o tema e com a tese?

$\checkmark$ Existe algum modo de exemplificar esse argumento? 


\section{Quarto parágrafo - argumento mais forte}

$\triangleright$ Qual é o argumento mais convincente de que disponho?

$\triangleright$ Como ele se relaciona com o tema e com a tese?

$\checkmark$ Existe algum modo de exemplificar esse argumento?

$\checkmark$ Qual é a relação entre esse argumento e os dois anteriores?

\section{Último parágrafo - conclusão}

$\checkmark$ Como recapitular esse texto?

$\checkmark$ Que solução proponho para esse problema do trabalho infantil?

$\checkmark$ Como essa solução se relaciona com a realidade?

Corrija as atividades e reserve uma aula no próximo bimestre para entregar os textos e comentar os resultados, destacando os pontos fortes e identificando os pontos que precisam de maior atenção.

\section{Expectativas de aprendizagem e Grade de Avaliaçã̃o}

Ao terminar o $2^{\circ}$ bimestre da $3^{\text {a }}$ série do Ensino Médio, podemos transformar o momento de avaliação em uma oportunidade de compreender os acertos e problemas do processo de aprendizado da turma e de rever projetos e percursos. Ainda há tempo para mudanças e para aprimorar estratégias que produziram bons resultados. Para esse fim, precisamos estar atentos às diferentes fontes de consulta de que dispomos: tanto as atividades que foram feitas no decorrer do bimestre, como as finais.

Desejamos que nossos alunos e alunas se desenvolvam como cidadãos autônomos no que respeita à leitura e à escrita; que tenham autonomia ao prestar exames de acesso ao Ensino Superior. Isso inclui considerar como a linguagem constrói algumas das relações próprias do campo do trabalho. Para nós, neste bimestre, algumas habilidades se destacaram:

Estabelecer relação entre a tese e os argumentos apresentados para defendê-la ou refutá-la.

$\checkmark$ Elaborar estratégias de produção de textos argumentativos.

$\downarrow$ Inferir tese, tema ou assunto principal em um texto.

$\checkmark$ Relacionar informações sobre concepções artísticas e procedimentos de construção do texto literário com os contextos de produção e circulação social da arte, para atribuir significados de leituras críticas em diferentes situações.

$\triangleright$ Utilizar conhecimentos formais para formular hipóteses sobre o uso de determinadas variantes da lingua portuguesa presentes em um texto.

$\checkmark$ Compreender a literatura como sistema social que concretiza valores sociais e humanos atualizáveis e permanentes no patrimônio literário nacional.

$\triangleright$ Elaborar estratégias de resolução de questões de exames de acesso ao Ensino Superior.

Essas habilidades constituem o alicerce da avaliação que findará o bimestre. Nela, procuraremos compreender o desenvolvimento dos alunos nessas habilidades identificadas como centrais naquilo que elas representam de apropriação criativa e crítica da linguagem, tanto no papel de enunciador como no de coenunciador. Compreendemos criatividade como algo processual, assim como a leitura e a escrita. Processo que parte de um diálogo como a tradição, seja para continuá-la, para romper com ela ou para manter com ela alguma referência. 


\title{
Currículo de Língua Portuguesa
}

\author{
Ensino Fundamental (Ciclo II) e Ensino Médio
}

\section{O ensino de Língua Portuguesa: breve historico}

Particlpar da formaçąo dos alunos na disciplina Lingua Portuguesa Implica superar uma attidade apenas voltada para a informaça, uma vez que desejamos formar para o mundo do corhecimento por melo da lingusgem. Corhecer e o ato cognittwo de compreender para transformar a st eao mundo em que viemos, construindo relaços ente os diversos significados de uma mesma idela ou de um mesmo fato. Corhedmentoe, pols, uma rede de significados. Quem conhece, corhece algo ou alguem, e conhecer algo, portanto, e partidpar do processo constante de transformar e atribuir significados e relaçces ao objeto do conhecimento, seja ele o verbo, o resumo ou o texto literário.

Ate meados do seculo XVII, o ensino de Lingua Portuguesa, tanto no Brasll como em Portugal, Imltava-se a alfabetizaçao. Os poucos que prolongaram a sua escolarizaça passa vam dretamente a aprendzagem da gramatica latina, da retorica e da poetica. A Reforma felta pelo Marques de Porrbal, em 1759, tornou obrigatorio, em Portugal e no Brasil, o ensino da Lingua Portuguesa. Esse ensino passou a seguir a tradiça do ensino do latim, ou seja, passou a ser visto como ensino da gramatica do portugues. Ate o final do seculo XX, cbservamos ainda o ensino da retorica e da postica.
Gramatica, Retcrica e Poestica eram, pols, as disciplinas nas quals se faza o ensino da Lingua Portuguesa ate o fim do imperio. A disciplina Gramatica, alnda no seculo XX, passou a ser chamada Portugues, e fol crlado o cargo correspondente de professor de portugues. Mudar o nome, no entanto, náo significou mudar o objetivo: a disciplina Portugues manteve, ate a metade do seculo $\propto \mathcal{X}$ a tradiçăo da Gramatica, da Retorica e da Postica.

Fatores externos levaram a democratizaça do ensino: os filhos dos trabalhadores chegaram a sala de aula nas decadas de $1950 \mathrm{e}$ 1960. Mas, do ponto de vista Interno, poucas mudanças occrreram, a língua continuou a ser concebida como um sisterna centrado na gra matica vista como um Instrumento para atingr fins retoricos e poeticos.

Principalmente a partir dos anos 1970 , estudos de Linguistica começaram a visitar o ensino de lingua materna. Tals estudos, nos dferentes campos da linguagem, começaram a pressionar a escola rumo a mudanças signiffcattvas, nem sempre devidamente compreenddas ou aplicadas.

Vemos surgir a preccupaçăo com o ensino da língua organizado a partir de duas vas Inseparavels: corno objeto e como melo 
para o corhecimento. Ou seja, deveria ser apresentada como materia a ser analisada, minuclosamente, ao mesmo tempo em que proporcionaria ao sujelto a construçăo e a compreensto de conhedmentos do mundo. E, por Isso mesmo, ja nao poderia ser pensada de modo fragmentado, como mera decodificaçâo de conteodos e reprodução de Idelas, desconsiderando as experiendas de vida de seus Interlocutores, nao levando em conta seus conhedmentos previos e a legitimidade de seu saber, descontextualizando o ensino no exerdido mecanico e repetitivo, desvirtuando a gramatica ao valcrizar regras especficas em detrimento de multas cutras existentes.

Nesse sentido, o atual Curriculo nåo representa uma ruptura em relaça acs documentos ofidals que o precederam. As Propostas Curriculares do Estado de sao Paulo, construdas no periodo de 1986 a 1993 e que deram origem acs Parametros Currkulares Nadonals (PCNs) do Ensino Fundamental, de 1997, e aos PCNs do Ensino Medio, de 1998, constituem a base sobre a qual ele se desenvolve.

A partir desse contexto e seguindo conceltos solidos de denclas que estudam a Inguagem, explicitados nos PCNst da área de Linguagens e Codgos (2006), nossa proposta para a disciplina Língua Portuguesa nåo separa o estudo da linguagem e da literatura do estudo do homem em sodedade. Sabemos que o ser humano e um sujelto sodasel, que pode partidpar social e culturalmente no mundo em que vive. Mas como fundiona isso na pratica?

\section{Fundamentos para o ensino de Lingua Portuguesa}

A disciplina Lingua Portuguesa pode centrar-se:

a) no conjunto de regras que nos leva a produzir frases para, a partir dar, chegarmos aos enunclados concretos;

b) nos enunclados que clrculam efetivamente no cotidlano e seguem regras especificas que permitem a comunicaçăo.

Observe que, por regras, nato estamos necessariamente falando das gramaticals. Por exemplo, considere os tres bihetes a seguir.

Texto 1

Marla,

eu io chega tardl in casa og pruque o patraum aviso que vo percka fase hora elstra.

Texto 2

Marla,

provaveimente chegaral tarde a casa hole porque ful informado de que precksarel fazer hora extra.

Texto 3

patráo,

podré no Marla extra Informado a preckarel today porque ful pelo boss chey mol de que temprano fazer hova chegar. 
Mesmo com as dificuldades no uso da norma-padraso no texto 1, Identfficamos as intençoes do texto porque ele segue regras proprias da Lingua Portuguesa. O problema, do ponto de vista da comunicaça, encontra-se no texto 3.

Os textos 1 e 2 comunicam, mas ao clrcular na sodedade, dlante das possibilidades de Interpretaçao, provocam reaçoes distintas, que se relacionam com as diferentes situaçoes em que tals textos droulam: quem os val len? Por que? o que esses textos revelam de quem $\alpha$ escreveu?

Assim, os corhedmentos lingứsticos nao podem ser Imitados apenas pelo conhedmento da norma-padráo. Os textos fazem uso de estruturas gramaticals, e verdade; e multos desses textos se organizam segundo a gramatica normatwa para a sua acel taça na socledade.

Ha estruturas que surgem das relaçoes entre as frases, entre os paragrafos e, ate, entre os textos de que a gramatica tradicional nao da conta, e tals estruturas merecem abordagem no cotidlano escolar. Alem disso, ha o aspecto social da lingua que, como organismo vvo e pulsante, transforma-se a toda hora e relaciona os textos com o momento de produçso e de leitura.

A attividade de Lingua Portuguesa deve evitar que 0 aluno se sinta um estrangeiro ao se utilizar de sua propria lingua: e necessario saber lidar com os textos nas dversas situaçoes de Interaçăo social. É essa habilldade de Interagir linguisticamente por melo de textos, nas situaçces de produça e recepço em que clrculam soclamente, que permite a construça de sentidos. Desse modo, deserwolve-se a comrpetencla discursiva e promove-se o letramento. Assim, o centro da aula de Lingua Portuguesa eo texto, mas o que isso significa realmente?

0 texto ao qual nos referimos e aqu compreendido em sentido semlotico, poderdo, assim, estar organizado a partr da combinaça de dferentes linguagens, naso apenas da verbal.

Desse modo, uma foto, uma cerla de telenovela, uma cança, entre multas outras posst billdades, sao textos. A principal propriedade de um texto e que ele comunica, dando a impressao de totalidade aos interlocutores. Em outras palavras, tanto quem o produs como quem o recebe tem a impresså de que aquela produça esta completa no proposito a que se destina.

Os textos sto utllzados em atividades soclals varladas. Embora um texto seja sempre uma produça Indimdual, cada esfera de utlleaça da língua constrol seus modelos relativamente estavels orlentados pelo conteodo termatico, pelo estilo e pela construçao composkidonal. É o que denomnamos generos textuals. Alguns exemplos de genero sao aula, fofoca, monografla, debate, horoscopo, conversa telefonica, conversa em roda de amigos, tese de doutoramento etc.

Os generos textuals sao, ao mesmo tempo, eventos linguisticos e açoes socials. 
Fundonam como paradigmas comunicativos que nos permitem gerar expectativas e previsoes ao elaborarmos a compreensto de um texto. E, embora sejam definidos tanto por aspectos formals como funcionals, nao ha dovidas, entre os estudiosos, de que a funçáo $e$ mals importante do que a forma.

Os generos textuals sto artefatos linguisticos construidos historica e culturamente pelas pessoas para atingir objetwos especificos em sltuaçoes soclals particulares.

Por tipologla textual entende-se uma especle de sequenda teoricamente definida pela natureza linguística de sua composiçăo. Enquanto os generos textuals sao illmitados, os tipos textuals abrangem cinco categorlas principais: narrar, relatar, prescrever, expor e argumentar. Como parte de sua competencla comunicativa, os enundadores dispoem de t1pologlas, adquindas por contato ou ensho orgarizado, necessarlas para compreender ou produzir textos especificos. Desse modo, as tipos textuals incorporam os generos de discurso particulares. Por exemplo, dentro da tipologla narrativa encontramos os generos conto, fabula, apologo, romance, telenovela etc.

o nivel de letramento e deterrininado pela varledade de generos textuals com os quals a crlança ou o adulto conseguem Interagr. Todos os textos surgem na socledade pertencendo a diferentes categorlas ou generos textuals que relaclonam os enuncladores com attvidades soclals especificas. Nao se trata de pensarmos em uma lista de caracteristicas que compoem um modelo segundo o qual devemos produzr o nosso texto, mas de compreender como esse texto funclona em socledade e de que forma ele deve ser produzido e utilzado a fim de atingir 0 objetwo desejado.

Nesse sentido, discurso sera entendido como a materialidade do texto, organizado em um dado genero, insentdo em uma situaçao real de interaçaentre sujel tos en determinado contexto. Em outras palavras, discurso e a lingua gem em Interaçao, que leva em conta o que esta dito ou slenclado, os valores, os sentimentos, as vivenclas e as visces de mundo dos interlocutores erwolvidos em uma determinada situaçâ comuricativa. É o produto de uma enunda ça formado por todos os elementos que concorrem ao processo de slgnificaças, de tal modo que supera a simples somatorla dessas partes. O discurso esquematiza as experienclas a fim de torna-las significantes e compartllhavels.

A proposta de estudar a lingua constderada como uma attvidade soclal, como um espaço de interaça entre pessoas, num determinado contexto de comunicaçao, Implica a compreensáo da enundaça como ebxo central de todo o sisterna linguístico e a importancla do letramento, em funçào das relaçces que cada sujelto manterm em seu melo.

Alguem, com seu trabalho físico e mental, produz um texto em determinado tempo $\mathrm{e}$ espaço. Esse texto sera interpretado por outro Indviduo, com uma personalidade espedfica, 
que pode ou nao estar nos mesmos tempo e espaço do produtor. A esse fato que leva em conta esses tres elwos (tempo, espaço, Indviduo) na produça/recepça textual denominamos enunclaça. Esse acontedmento nstaura um "eu" que, dentro do enundado, assume-se como o responsavel pelo ato de linguagem e um "voce" constiturdo por esse eu enundador do texto.

Para o trabalho escolar com textos, torna-se necessarlo compreender tanto as caracteristicas estruturals (ou seja, como o texto e felto) como as condiçoes soclals de produçao e recepçaso, para refletir sobre sua adequaça e funclonalidade. Por exemplo, falar de curnculum vitae, na escola, nao pode ser separado do campo da atividade "trabalho", o que nos leva a pensar no Individuo que procura emprego, no empregador - em suas expectativas, habilidades -, em outros generos de discurso assoclados, tals como entrevista de emprego, anúnclo de jornal etc., e nas questoes soclals de desemprego, primeiro emprego e competitividade no mundo do trabal ho.

Em sintese, ternos:

TIPO

Composiçâo linguistica que organiza pela sua predominánda em um texto - $\alpha$ diferentes generos textuals.

\section{GËNERO}

Evento Inguistico sccial que organiza os textos a partir de caracteristicas sociossemiotlcas: conteódos, propriedades funclonals, estilo e composiçăo estrutural.

\section{TEXTO}

Totalidade semiotica de sentido constitưda por uma combnaça de linguagens $e$ operaçoes aplcadas ao fluxo de uma produçáo semiotica concreta.

\section{ENUNCIAÇÃO}

Ato ou acontecimento pelo qual um individuo errpirico, por melo de trabalho fisko e mental, produz um enunclado que sera recebrdo, em processo interatvo e social, por outro Indviduo. Esse acontecimento instaura um "eu" que, dentro do enunciado, assume a responsabildade do ato de linguagem e um "voce" corstiturdo pelo "eu" (enunclador) do texto.

\section{DISCURSO}

Produto de uma enundaça composto de todos os elementos que concorrem ao processo de significaças, superando a soma torla das partes. O discurso esquematiza as experienclas a fim de torna-las significantes e compartlhâvels.

Centrar o ensino de Língua Portuguesa no texto requer o desemwolvimento de habilldades que ultrapassam uma visto reduclonista dos fenomenos linguístico e literario.

- discurso literario, como realidade linguística e socdal, atravessa todos os tipos textuals. Desse modo, podemos encontrar, praticamente, qual quer genero textual em uma obra literaria: uma carta, um poema, um conto, uma cantiga, uma notida de Jornal, uma recelta etc. SIrvam de exemplos " Poema tirado 
de uma notida de Jornal", de Manuel Bandelra, e "Recelta para fazer um poema dadaista", do romeno Tistan Tzara. o que, naturalmente, náo sigrifica que qualquer carta ou noticla de jornal sejam consideradas literatura.

Se o texto, em qualquer genero textual, propidar ao leitor um desafio em que, esteticamente, se misturem a construçáo da cul tura com o prazer de ler, sera um forte candidato a pertencer a esfera Iterarla. Isso porque a literatura e, antes de tudo, um desaflo ao espirito. No entanto, ela e tambem uma instituçaso. Ou seja, naso e apenas a compreensao de texto ou um jogo emodonal de gostanano-gosta. Tal visao redue o papel historico da literatura como participante na construçâo da identidade de um powo.

A literatura participa da consoldaça da tela humana que chamamos "socledade". Entáo, o prazer do texto se constitul como jogo entre a compreensto do proprio texto como fenomeno de leltura Iteraria e a Interaça com a delicada trama social que e a institulça literdrla. O texto Iiterario vocaciona-se a eternidade e a reflexaso humana, mas e atualizado por uma comunidade leitora que segue um intrincado e plural conjunto de regras semloticas e soclals.

\section{Língua Portuguesa para o Ensino Fundamental (Cldo II) e o Ensino Médlo}

De acordo com o Curriculo, as propostas de ensino de lingua nos segmentos Fundamental II e Medio corwergem em seus objetwos.
Ambas tem a pretensao de culdar para que os estudantes sejam capazes de simbolizar as experienclas (suas e dos outros) a partir da pa lavra (oral e escrita), refletindo sobre elas medlante o estudo da lingua, Instrumento que Ihes permite organizar a realidade na qual se Inserem, construindo significados, nomeando conhecimentose experlenclas, produzindo sentidos, tornando-se sujeltos.

No entanto, ha em cada um dos segmentos as especificddades proprlas que auxillam o trabalho do professor na escolha dos conteodos e objetwos a serem deserwohidos nas aulas de língua. Os criterios para articular os conteodose as competenclas do estudo da língua no Ensino Medlo devern ampliar, necessarlamente, os estudos deserwolvidos no Ensino Fundamental II, observando uma progressto que possa diversificar, ao longo da escolaridade, abordagens, contextos, sltuaçoes etc.

Esses criterios serao apresentados, detaIhando as espedficldades, nas propostas para cada um dos segmentos.

Sobre a organtzaçăo dos conteúdos básicos para o Ensino Fundamental (Gdo II)

o presente Curriculo, em consonarncla com os Parametros Curriculares Nacionals e com os avanços feitos ate o momento, parte do estudo do texto - apresentado sempre em uma dacta sttuaça de comuricaça - como base para o estudo de conteódos, o desenvolumento de habblidades e competenclas - 
especialmente de leitura e escrita - e de propostas metodologicas de ensino e aprendzagem.

Nesse sentido, baseamo-nos em uma ampla concepça de texto, visto sob dols aspectos princlpals:

- Ele sera compreendido em sentido semiotlco, podendo, assim, estar organizado a partir da combinaçao de diferentes linguagens, náo apenas a verbal (uma foto, uma cena de telenovela, uma cançăo, entre multas outras posslbilidades, serao compreendidas como textos).

- o estudo do texto tera alnda como premissa sua Inserçáo em dada situaça de comuricaça - podendo, dessa forma, ser entendido corno sinonimo de enunclado. Ele naso sera visto como objeto portador de sentido em sl mesmo, mas como uma tesstura que, inserida em contextos maks amplos, materializa as trocas comunicativas. Esse resultado nao deve ser analıado apenas como uma organizaçăo de frases e palasras, mas como forma de representaça de valores, tensces e desejos de indviduos, Inseridos em diversos contextos soclaks, em um momento historico determinado.

Com o objetivo de apresentar o texto em situaçoes de comunicaçao diversificadas, propornos, para cada bimestre, um ebxo de organizaça. Cada elxo tera o texto em uma dada sltuaça como base para a organizaçăo dos estudos. Assim, em todos os anos do Ensino Fundamental II, serao estudados:
- 12 bimestre: Tipologlas e generos textuals

- $2^{2}$ bimestre: Tipologas e generos textuals

- 32 bimestre: Texto, discurso e historia

- 42 bimestre: Texto, discurso e historia

\section{Os elxos de organizaçăo dos conteúdos}

\section{Tipologlas textuals}

O ensino-aprendizagem partira das organizaçoes internas basicas dos diferentes textos (narrar, relatar, prescrever, expor e argumentar). Neste ebxo, o cbjetwo central, do ponto de vista dos conteudos, e compreender que, nas sltua çoes reals de comuricaçao, diferentes textos, compostos em diferentes Inguagens, podem apresentar uma forma de orgarizaça interna semelhante. Essa orgarizaçao, de alguma for$\mathrm{ma}$, contribul para o sentido que podera ser dado a esses textos, em diversos contextos.

\section{Generos textuals}

Este elxo reladona os textos com suas funçces sodocomunicativas. Seráo selecionados dols generos para estudo em cada bimestre. Essa escolha reladona-se com a tipologla textual apresentada naquele ano, uma vez que cada genero prillegla uma ou mak tipologlas em seus modos de organizaçao. 0 objetino princlpal dessa separaçao, do ponto de vista da escoha do conteodo, e apresentar o texto e suas especificldades funclonals, constituidas pelas demandas das situaçoes de comuricação nas quals eles sáo constrưdos. 


\section{Texto e discurso}

Neste ebro, o texto sera visto em amblto ainda mals amplo. Sendo organtzado a partir de uma ou mals tipologlas e em um dado genero, cada texto surge dentro de um contexto comunicativo multo mals complexo, inserido em um universo de valores conflitantes de uma dada socledade. A organizaçáo tipologica e, prindpalmente, do genero textual esta em relação direta com os valores soclats que orientaram sua constitulçăo, em dado momento historico. Tendo essas premissas, escolhemos quatro grandes discursos para estudo: o publlcltario, o Jornalistico, o artistico e o portico.

\section{Texto e histórla}

Este ebxo abarca os tres anteriores (assim como cada nowo elxo proposto abarca o anterior ou os anteriores). Nesse momento, os educandos seräo corwidados a refletir sobre valores sodals, politicos, economicos, culturals etc., materialzados em textos de diversas tipologias e generos, construidos em diferentes situaçoes de comunicaçaso historicamente determinadas.

É preciso destacar alnda que os conteudos serao apresentados nas serles seguindo outros aspectos orgarizadores. Um deles e o deserwolvimento das habilidades de leltura, de escrita, de fala, de audição e as relaclonadas aos aspectos gramaticals da lingua.

Os conteódos mendonados estao assoclados a dferentes habilidades: estudar a tipologla narrativa, por exemplo, implicara deservolve-la pondo en funclonamento habll- dades de leltura, escrita, cralidade, audçăo e de estudos de aspectos gramaticals. Isso sigrifica que em todos as bimestres, em todas as serles, os conteudos seráo apresentados a partir do deserwolimento dessas dferentes hablldades.

No que diz respelto acs estudos dos aspectos gramaticals da língua, gostariamos de ressaltar ainda doks pontos: havera momentos de sistematizaça, com destaque maior para os temas que geram mals problemas de uso para os falantes (em razao das diferenças entre norma-padras e cutras nomas). Alem disso, nosso ohar gramatical segura a organizaçao tradicional apresentada pelos lvros ddaticos, tendo, no entanto, ocuidado de expor os temas dentro da perspectiva das varledades linguisticas e textuals.

Em relação a leltura Iteraria, e predso anda considerar dols aspectos: como fol dito anteriormente, o carater Iiterario de um texto nao esta, necessarlamente, atrelado a seu genero. Todos os generos e tipologlas estudados podem, a priorl, fazer parte desse untverso. Lembramos que a dimensso linguistica do texto literario interage com o fato de que a Iiteratura e uma institulçà sodal que legitima ou năo os seus textos.

O professor precka garantir em seu pla nejamento que o texto literario entre corno objeto de analise e interpretaçâ, mas tambem como pratica social, resgatando a dimensao frultuva da literatura. 0 aluno deve desenvolver-se como leltor autonomo, com preferenclas, gostos e historla de leltor. 
Assim, seja qual for a tipologla ou o ge nero em estudo, o texto literario pode e deve ser trabalhado permanentemente, uma vez que e elemento fundamental na construçăo da competenda leltora e na formaça do habito leltor do estudante.

Sobre a organizaçăo dos conteúdos básicos para o Ensı́no Médio

No Ensino Medio, os conteudos discipllnares foram organizados em quatro grandes campos de estudo que se entrecruzam e se orlentam a partir de importantes questionamentos soclas. Cada um desses elxos sugere uma questao que sera respondida no decorrer do bimestre. Essa questao central estabelece a abordagem dos diferentes conteudos em cada campo de estudo da disciplina. Por Isso, um mesmo conteódo pode surgr em mals de um bimestre, de acordo com os Imites estabelecidos pelo elxo crganizador.

Esses ebxos centram-se no individuo que se constitu na linguagem verbal como ser humano, em sua subjetividade, portanto, unico em relaça aos outros, e ser soclal, ou seja, parte constitutiva de um todo historico, social e culturalmente construido.

Os campos de conteódos tratam o fenomeno lingurstico nas dimensoes discursiva, semantica egramattcal. Dessa forma, procura-se deserwolver o olhar dalatico entre o Intrnsecamente linguistico e as dimensces subjetivas e sodals.
Os campos de estudo de organizaçáo dos conteúdos

\section{Linguagem e socledade}

Neste campo, o objetwo central e a analse, principalmente externa, da lingua e da litera tura, em sua dimensáo sodal, como instituçcees.

\section{Leltura e expressăo escrita}

Neste campo, o objetwo principal eo estudo das caracteristicas dos generos textuals, desde o lugar do receptor e/ou produtor na materialidade escrita da linguagem verbal. Os generos textuals sao concebldos como acontedmentos sodals em que interagem caracteristicas especificas do genero com elementos soclals e subjettros.

\section{Funclonamento da lingua}

Neste campo, o objetivo prindipal e a análse interna da língua e da literatura como realidades (untersemioticas).

\section{Produçăo e compreensăo oral}

Neste campo, o objetwo prindipal e o estudo de aspectos relacionados a produçąo $\mathrm{e}$ esculta do texto cral.

Dessa forma, na malor parte das vezes, optamos por inter-relacionar tals campos de estudo em uma determinada abordagem. Assim, por exemplo, ao falarmos do genero poema em gêneros textuals, no primelro bimestre, parece-nos importante assocla-lo a outros, como a lusofonla e a historla da Úngua Portuguesa, e a construça da textualidade. Por sua vez, 
tratarmos da lusoforia remete-nos facilmente as relaçoes historicas entre linguagem e gramatica, e assim por dante. Em outras palavras, os diferentes campos de estudo devem ser trabaIhados, quase sempre, Interligados, com vistas a aprofundar o elxo orgarizador do bimestre.

Sobre a metodologla de ensino-aprendizagem dos conteúdos básicos

Para apresentarmos os aspectos centrals da metodologla deserwolvida na area de Língua Portuguesa, consideramos oportuno divldl-los em duas partes: Ensino Fundamental e Ensino Medio.

No Ensino Fundamental, a organizaçao metodologica segue algumas premissas:

- Em todas as series, no $1^{2}$ bmestre, o ebxo princlpal e o estudo de um agrupamento tpologico (narrar, expor, descrever açoes e argumentar, respectivamente, da $5 \mathrm{~s}$ serle/62 ano a ge serle/gs ano). O $2^{s}$ bmestre, por sua vez, e orgarizado em torno do estudo de generos textuals que apresentern, predominantemente, o agruparnento tipologico estudado no bimestre anterior. Ja nos $3^{2} \mathrm{e}$ 42 bimestres deserwolve-se, em cada um, um projeto, que engloba a tipologla e os generos estudados, Inserindo-os em uma perspectiva discursiva. Essa opçso metodologla pareceu-nos articular tres aspectos fundamentals nos estudos de língua contemporaneos: os agrupamentos tipologicos, os generos e o dscurso.
- Em todos os bimestres, sao apresentadas, em medla, anco Situaçoes de Aprendr zagem. Desse modo, para o estudo da thpologla argumentativa, no 18 bimestre da an serle/ga ano, sao apresentadas anco Situa çoes de Aprendizagem; para o $2^{2}$ bimestre, com o objetwo de estudar generos como o texto de opiriso, sao apresentadas mals cinco, e assim sucessivamente. Cada uma das Sltuaçoes pode ser compreendida como uma proposta de sequencla ddatica, com outras sugestoes de encarinhamento no Caderno do Professor.

- Em cada situação de Aprendragem sá deserwolvidos, em concomitäncla com o estudo tipologico, de genero ou de discurso, doks aspectos:

a) Estudo de conteados: em todas as sequenclas didaticas, ha conteódos especficicos sendo trabalhados (caracteristicas de um genero ou tipo$\log l a$, aspectos gramaticals etc.). Eles sto os temas comuns de estudo linguistico, vistos em uma perspectiva de varledades linguisticas, assoclados a questoes de generos, tipologla ou qualquer cutro conteodo necessario ao deservolvimento de habilidades leltoras (a IntertextuaIIdade, por exemplo), escritoras (a coesta e a coerencla, por exemplo) e de oralidade (estudo de generos orals, como apresentaçoes ou debates, entre outros). 
b) Deserwolvimento de habilidades centradas em quatro grandes competenclas: escrittora, de leltura, de habblldades orals, linguistica. Cada situaçăo, no Caderno do Professor, começa com um quadro, que indica os conteudos e as habilidades que serao deserwolydos. No texto do Caderno do Professor propriamente dito, encontra-se uma sequencla didatica, ja organizada de forma a contemplar as quatro corricetenclas mencionadas. lsso esta marcado no texto com expressoes corno "para - desermolvimento de habildades de leltura...".

Ja no Ensino Medo, consideramos:

- Em todas as serles, a valorizaçáo de interfaces entre o corhedmento reflexdvo de conteudos Inguisticos e literarios e o cotldlano cultural em que o aluno esta Inserido. 0 objetivo e que tals conteodos sejam nao apenas "passados", mas que se tornem objato de constante reflexao. Para esse fim, valorizam-se diferentes esferas de at1vidades com a linguagem, que a consideram a partir de varladas perspectivas (extra e intralinguisticas), visando a surpreende-la em sua multiplicldade dinamica e soclal.

- A nao dissao do estudo da Úngua Portuguesa nas tradicionals frentes (Literatura, Gramatica e Redaça). lsso se da por diferentes motivos: a) O texto Iiterario, pela sua natureza, pode ser contemplado em diferentes dlscipinas. A escolha, contudo, de situar o estudo literario dentro da disciplina Lingua Portuguesa deve conddonar e orlentar as clhares e a pratica ddatica com tal texto. Desse modo tambem, o estudo literário, na escola, abre-se ao dialogo com outras disciplinas, partlclpando nas diferentes estrateglas de formaçăo do leltor.

b) o estudo da Lingua Portuguesa, tal como aqul proposto, náo e satisfatorlamente atendido na tradicional divtsao em trés frentes. Vale lembrar que partimos sempre, em nossos estudos, de um determinado contexto soclocultural que encaminha e condiciona - nosso trabalho com a linguagem. Esse mesmo contexto e tarrbem o ponto de chegada, de tal modo que o corhedmento de linguagem possa, efetivamente, propidar a transforma ça da realdade da qual partimos.

c) O processo de escrita, quando const derado em sua dinamica socdal, ultra passa as propostas tradidonalmente convencionals de uma aula de redaçao ou de produçaso textual. Isso porque ensinar as regras inerentes a estru tura de detemnado genero textual nà e necessarlamente permitir que o educando tenha uma experlenda real 
com o processo de escrita. Escrever e uma pratica social e assim deve ser sempre considerada. Essa perspectiva náo deve desaparecer da proposta pedagdgica da disciplina Língua Portuguesa, mesmo quando ela se detiver em estudos morfossintaticos ou que exjam maior abstração.

d) O conhecimento compartimentado em Gramatica, Literatura e Redaça nas promove o desermolvimento de uma consclenda linguistica de produça e recepcáo textual que se evidenda em todas as praticas sodals.

- Em todos os bimestres, sao apresentadas, em medla, anco situaçoes de Aprendizagem. Essas Situaçoes Intercalam diferentes objetivos linguisticos, literarios e soclals, o que possibilita um movimento espiralado de construçäo de conhecimentos. Esse movimento de ir e vir permite retomar at1vidades realizadas em outros momentos, analisando-as a luz de nowos conceltos construidos em sala de aula. Alem disso, posslbilita que o professor tenha tempo suficlente para a correção de textos produzidos pelos alunos.

- O deserwolvmento de habilidades entrelaçase ao corhedmento de conteodos da area da unguagem, particularmente a linguagem verbal, visando a construir uma ónica realldade. Cada situaçăo de Aprendizagem, no
Caderno do Professor, começa com um qua dro que indka cs conteodos e as habllidades que serăo desenvoludas. Cada sltuaça de Aprendizagem faz interagr diferentes habiltdades que se deseja que os educandos desenvolvam com conhecrmentos especificos dos estudos literarios e linguísticos. A sequenda de conteodos, naso obstante pricrize o desenvolvimento de hablidades, procura respeltar, sempre que possivel, a cordem mals comum encontrada nos diferentes materials didaticos a que o professor tem acesso. Podernos dtar varios exerrplos, entre eles, o fato de aprofundarmos a discussáo do que e Literatura na 12 serle, discutirmos o Romentismoe o Realismo na $2^{\mathrm{a}}$ serle e discorrermos scbre a Moderridade na ja serle. Tambem, pelo mesmo motiwo. detemo-nos primairoem aspactos morfologicos para, depols, adentrar na sintaxe.

Sobre os subsidios para Implantaçăo do Curriculo proposto

A Implantaçáo de um Currículo em uma rede, espedalmente nas proporçces de uma rede estadual, pressupoe que sejam definidas e executadas algumas açoes para seu efetho fundonamento.

Nesse sentido, o Curriculo do Estado de Săo Paulo organizou-se, do ponto de vista do apolo para o trabalho pedagogico em sala de aula, com base em tres suportes: o Caderno do Professor, o Caderno do Aluno e os videos dos espedalistas. 
Os Cadernos do Professor Indicam as orlentaçces bassicas do Curriculo, sugerindo sequenclas didaticas e indicando quals sao os conteudos e as habildades basicas em cada Situação de Aprendizagem.

0 mesmo ccorre nos Cadernos do Aluno: em consonancla absoluta com os Cadernos do Professor, eles apresentam exerciclos que deserwolvem os conteodos e as habilidades indcadas em cada situaçao de Aprendizagem.

Os videos com os especialistas, por sua vez, foram organizados a partir dos principals elxos organizadores da disciplina Lingua Portuguesa, de acordo com cada segmento (Ensho Fundamental ou Ensho Medo). Assim, em cada video, foram apresentados os temas (gramatica, generos, leltura e escrita no Ensino fundamental; leitura literaria, estllo e educaçao, produça textual e trabalho com generos no Ensino Medio) mostrando de que forma eles aparecem no Caderno do Professor.

Sobre a organ|zaçăo das grades curriculares (sérle/ano por bimestre): conteúdos assoclados a habillidades

Atualmente, buscando a renovaçăo da disciplina Lingua Portuguesa, multos se voltam para os generos textuals. "Temos de trabalhar os generos!" tornou-se parte do discurso corrente na escola.

No entanto, vale o alerta: sem conhecer bem o tema, trabahar com generos pode tra- zer mals problemas do que soluçoes. Promover uma aula baseada no concelto de genero textual permite o deserwolvimento da identidade cldada de nossos alunos, mas exige considerar a lingua portuguesa como uma athdade hur mana, um melo, por excelencla, de existir no mundo. kso nos desafla a levar essa lingua para a sala de aula o mals proxdmo possivel de como ela e surpreendida em seu uso cotidano, por vezes deslocando-a do ideal de correçao apresentado em gulas gramaticals.

Todas as atividades humanas estao rela clonadas a utllizaçao de linguagens e estas nao s\$o apenas feltas de palavras, mas de cores, formas, gestos etc. Para se tornarem "lingua gem", tals elementos predsam obedecer a certas regras que hes permitam entrar no jogo da comuricaça. Uma delas e que toda manifestaçao da linguagem se da por melo de textos, os quals surgem de acordo com as diferentes attividades humanas e podem ser agrupados em generos textuals.

Compreendemos generos textuals como modelos comunicativos que nos possibilitam gerar expectativas e previsoes para compreender um texto e, assim, Interagir com o outro.

Apenas para exemplificar, Imagine a confusto causada por uma simples conta de luz se ela vlesse, a cada mes, escrita de modo diferente, sem seguir um padrá. Quando recebemos uma conta de luz, recorhecemos - por melo das habilldades que desenvolvemos ao longo 
da vida - o modelo. Desse modo, sabemos para que serve e revelamo-nos competentes para localizar as Informaçoes mals Importantes, delxando de lado as que náo nos interessam, ou seja, conseguimos orgarizar a nossa vida. Isso porque conta de luz e um genero textual. Conta de luz, telenovela, fofoca, aula sao alguns exemplos de generos que, pelo constante uso soclal, nao oferecem multas dificuldades de compreensao. o mesmo nao podemos dizer de outros generos textuals menos frequentes em nosso cotidano, mas tambem Importantes, tals como a cronica, o editorial, a reportagem, o romance, 0 artigo de opinas, o ensalo etc.

Os generos surgem de acordo com sua funçao na socledade; seus conteôdos, seu estllo e sua forma estáo sujeltos a essa funça.o. Isso quer dizer que conhecer um genero nào e apenas conhecer suas caracteristicas formals, mas, antes de tudo, entender sua funçà e saber, desse modo, Interagir adequadamente. Em outras palawras, deserwolver habllidades que possibilitem essa interaça.

Um enorme desafio: valorizar forma $e$ funçao como uma unica realidade Interativa!

Pode ser relativamente simples ensinar as caracteristicas formals de um genero; por exemplo, uma carta sempre começa com um vocativo. Mas ensinar o uso soclal dessa carta, bem como a funçao e o valor desse vocatwo, e multo mals desaflador. Possibilitar que o aluno desenvolva as habilidades necessarlas para que se aproprie de um determinado ge nero textual nas apenas como uma serie de caracteristicas, mas como realidade dinamica e sodal, e o nosso espaço de trabalho na discIplina Úngua Portuguesa.

Voltemos ao exemplo da carta. Uma vez que os generos sto produtos culturals construfdos por determinada comunidade historico-soclal, uma carta que nao tenha vocativo, mas que comece com algo como "Que saudade de voce!" continuara sendo uma carta. Alem disso, uma carta para minha mà náo tera a mesma forma nem, provavelmente, a mesma funçao daquela dirigida a uma crlança ou ao dretor da escola. Por esse motivo, ensinar uma lista de caracteristicas formals (o que ja náo e pouco!) nao sera sufidente para garantir que um aluno salba escrever ou ler bem. Faz-se necessario deserwolver as habildades que asseguram que o genero textual seja visto como realidade discursiva e dnamica e, a mesmo tempo, produto linguistico e soctal.

O desenvolwmento de habilidades assocladas a um Curriculo que se alicerça no trabalho com generos textuak pressupce que se promova o convivio com esses generos.

É Importante pensar em para quem se escreve, por que se faz, qual a real necessidade de faze-to, o que o leltor efetivamente conhece sobre o tema, o que pensa dele, como fazer-se compreender, como usar a língua na produçâo 
desse texto, como o texto solicita uma ou cutra estrategla de leltura.

Tals questoes, na escola, tornam necessarlo cons truir um Cumículo que valorize a funçao soclal do texto e a sua forma em Interface com o desernvolvimento de habilidades que possiblIitem a reflexao lingurstica e socdal da interaçao do Indlviduo com a linguagem.

Na pratica, isso significa considerar a cultura na quel o genero seconstitul corno aço soclal. Em outras palavas, devernos considerar ateque ponto a comunidade que faz uso desse genero efetiva mente se aproprlou delee como o fez Lembramos, contudo, que a comuridade que faz uso de determinado genero e composta de ind Miduos, entre os quals professor etou aluno devern se ndur.

Isso nos leva a novas questoes: Como de serwolver aproprladamente as habilidades que promovem a relaçao do aluno com um determlnado genero se sua leltura e escrita nao fazem parte do cotidlano? Em outras palavras: Como escrever um artigo de coiniso se nas ha o habito de pensar em quemleo que seescreve? Comodstinguir o registro de formalidade na escritta de um texto se nao se sabe quando usar a norma-padrao? Como ler bem se naso se sabe como agr dlante de uma palavra descorhedda?

A Istadeperguntase taograndequantolou malor do que!) o nummero de generos que extste. Os generos sao produtos de cultura de deterrrinada sodedade. Constiturdos por certos conteudos, alem de estlo e forma proprios, apresentam funçoes soclals espedficas. Tornarn-se, desse modo, modelos comuricatwos que permitem a interaçao social. 0 trabalho com generos textuals na escola pressupoe um modo proprio de se reladonar com a linguagem e com o Curriculo da Lingua Portuguesa, um modo emribasado no deservolvimento de hablldades. Significa oultvar uma attitude educacional alicerçada em solido conhedmento da linguagem, vista como pratica cotidana. Pode ser desaflador, mas vale a pena!

Neste Curriculo, as hablldades estao assocladas 305 conteudos que promovem a melhor compreensao do genero textual tomado como realidade dintrivica, acontecimento que perrilte a construção psicossoclal dos interlocutores.

Referênclas

BAKHTIN, Mkhall. Estética da crlaça verbal. Tradução Paulo Bezerra. 4. ed. sá Paulo: Martins Fontes, 2003.

Marxismo e fibsofía da Mnguagem. S\$o Paulo: Hucltec, 2006.

BOSI, Alfredo. O ser e o tempo da poesla. SaO Paulo: Cultrtx, 1997.

BRANDÁO, Helena H. Nagamine. introduçáo à anallse do discurso. Campinas: Editora da Unt camp, 2004

BRASIL. Secretarla de Educaçăo Fundamental. Parametros Curriculares Naclonals: Lingua Portuguesa. Brasilla: MEC/SEF, 1998.

BRASIL. Ministerlo da Educação. Gula de Wwos didáticos PFLD 2008. Língua Portuguesa/ Ministerio da Educaça (Anos Finals do Ensino Fundamental). Brasilla: MEC, 2007. 152 p. 
CANDIDO, Antonlo. O estudo analitico do poema. Sao Paulo: Humanltas, 1996.

CARONE, Fláma de Barros. Morfossintaxe. Sao Paulo: Ática, 2004.

CARVALHO, Nely de. Publicidade: a linguagem da seduçao. Sso Paulo: Ática, 2002.

COMPAGNON, Antoine. O demónlo da tearla: Iiteratura e senso comum. Belo Horlzonte: Edtora da UFMG, 1999.

D'ONOFfuO, Salvatore. Reorla do texto: prolegome nos e tecrla da narrativa. Sao Paulo: Ática, 2006.

Dionisio, Angela Palva; bezerra, Marla Auxdladora; MACHADO, Anna Faquel. Generos textual's e ensino. Flo de Janeiro: Lucerna, 2002.

ECO, Umberto. Ensalos sobre a Mteratura. Traduçao Ellana Agular. Rlo de Janeiro: Record, 2003.

FAIRCLOUGH, Noman. Dscurso e mudança social. Traduçao Izabel Magalhaes. Brasilia: Unversldade de Brasilla, 2001.

JOUVE, VIncent. A leitura. Traduçao Brigitte Hervor. SaO Paulo: Unesp, 2002.

$\mathrm{KOCH}$, Ingedore Villaça. O texto e a construçăo do sentido. Sao Paulo: Contexto, 2003.

LEFNER, Dela. Ler e escrever na escola. o real, oposstvel e o necessario. Porto Alegre: Artmed, 2002.
MAAR, Wolfgang L. O que é politica. Sao Paulo: Brasillense, 1994.

MARCUSCHI, Lulz Antonio. Produçao textual, anallse de gêneros e compreensto. sao paulo: Parabola, 2008.

ORLANDI, EnI Pulcinell. Discurso e leitura. Sao Paulo: Cortez, 2006.

$P C N+$ Ensino Médlo: Orlentaçoes Educadonals Complementares aos Parametros Curriculares Naclonaks - Linguagens, Codigos e Suas Tecnologlas. 2006. Disponivel em: <ittp/Nportal. mec.gov.br/seb/arqulvos/pdf/linguagens02 . pdf . Acesso em: 22 Jan. 2010.

PEDRO, Emilla Fibeiro (Org.). Anallse critica do dscurso: uma perspectiva soclopolitica e funclonal. LIsboa: Caminho, 1997.

PERRENOUD, Phillipe. Construr competenclas de ensho desde a ercola. Porto Alegre: Artmed, 1999.

PIZANI, Alida Palados. Compreensáo da katura e expressato da escita. Porto Alegre: Artmed, 1997.

SALO PAULL (Estado). SEE-SPYCENP. Proposta CUNMalar: Ereino Medicyensho Fundemental (52 serie a ga serle). Sso Paulo, 1981-1997.

SILVA, VItor Manuel de Agular e. Rearla da Wteratura. Colmbra: Almedina, 2000.

VANDUK, Teun A. ideologla. Barcelona: Gedisa, 1999. 
ANEXO J - Quadro de conteúdos e habilidades em Língua Portuguesa - 1ª série EM (Currículo de Língua Portuguesa)

lingus

Portagues

Curriculo do Estado de SSo Paulo

\section{1? série do Ensino Médio}

\section{Conteúdos}

Esferas de attvildades soclals da linguagem

As diferentes midas

A lingua e a constituiçăo psicossocial do individuo

A lingua portuguesa na escola: o genero textual no cotidano escolar

A literatura na socledade atual

Lusofonla e historla da Ingua portuguesa

Leltura e expressð̃o escrita

Estrateglas de pre-leltura

- Relaçoes de corhedmento sobre o genero do texto e antecipaçao de sentidos a partir de diferentes Indidos

Estruturaça da atuvidade escrita

- Projeto de texto

- Construçáo do texto

- Revisáo

Textos prescrittvos (foco: escrita)

Projeto de atividade midlatica (reportagem fotografica, propaganda, documentario em video, entre outros)

Texto Ifrico (foco: leltura)

Poema: diferenças entre verso e prosa

Texto narrativo (foco: leltura)

Conto tradicional

Texto argumentativo (foco: escrita)

- Opinices pessoals

Texto expositivo (foco: leltura e escrita)

- Tomada de notas

- Resumo de texto audoisual (novela televisiva, filme, documentario, entre outros)

- Legenda 
Relato (foco: leltura e escrita)

- Notida

Informaças, exposiçăo de idelas e midla Impressa

Intencionalidade comunicativa

Estrateglas de pos-leltura

Organizaçăo da informaçao e utllizaçao das habilidades desenvolvidas em nowos contextos de leltura

Funclonamento da língua

Analise estilistica: verbo, adjetwo e substantwo

Aspectos lingứsticos especticos da construçào do genero

Construçąo da textualidade

Identificaça das palawras, sincnimla e ldelas-chave em um texto

Lexicografla: dicionärio, glossario, endclopeda

Vsao crituca do estudo da gramatica

Compreensăo e discussăo oral

A oralidade nos textos escritos

Discussao de pontos de vista: Literatura e Arte

Expressa oral e tomada de turno

\section{Habilidades}

Espera-se que, tendo como prindpal referencla as esferas de at/midades reladonadas com o estudo, bem como a construçăo semiotico-cultural do concelto de literatura, em situaçoes de aprendizagem orlentadas por athidades de leltura e escrita, os alunos façam uso de dfferentes tipos textuals, priorizando, contudo, a tipologia expositiva, e deserwolvam as seguintes habillidades:

- Relacionar o uso da norma-padrao as dferentes esferas de atividade soclal

- Identificar idelas-chave em um texto, concatenando-as na elaboraçăo de uma sintese

- Elaborar projetos escritos para executar atividades

- Elaborar sinteses de textos verbo-vsuals, compreendendo a Inguagem como realizaçăo cotidana em circulaçáo soclal por melo de generos textuals de diferentes tipologlas

- Reconhecer os elementos basicos da narrativa literária 
Lingus

Porbuguesa

Curriculo do Estado de SSo Paulo

- Reconhecer a língua portuguesa como realidade historica, sodal e geografica, como manifestaça do pensamento, da cultura e Identidade de um indkiduo, de um powo e de uma comunidade

- Elaborar estrateglas de leltura e de produçao de textos diversos (verbals e náo verbals), respeltando as suas diferentes caracteristicas de genero e cs procedimentos de coesto e coerencla textuaks

- Relaclonar linguagem verbal literarla com Inguagem nå verbal

- Construir sentido pela comparação entre textos a partir de diferentes relaçces intertextuals

- Analisar os efeltos semánticos e expressivos producidos pelo uso das diferentes classes morfologicas estudadas no bimestre: verbo, adjetho, substantivo 


\section{9 série do Ensino Médio}

\section{Conteúdos}

Esferas de atlvidades soclals da linguagem

A exposição artistica e o uso da palavra

Comunicaçăo e relaçoes sodals

Discurso e valores pessoals e soclals

Literatura e Arte como institulçoes sodals

Varledade lingurstica: preconcel to lingurstico

Leltura e expressð̃o escrita

Estrateglas de pre-leltura

- Corhedmento sobre o genero do texto e a antedpaçáo de sentidos a partir de diferentes indiclos

Estruturaça da attvidade escrita

- Projeto de texto

- Construçáo do texto

- Revisao

Texto prescritio (foco: escrita)

8

- Projeto de atuvidade extracurricular

Texto narrativo (foco: leltura)

- Cronica

Texto teatral (foco: leltura)

Diferenças entre texto teatral e texto espetacular

- Fabula

Texto Ifrico (foco: leltura)

- Poema

Texto expositwo (foco: leitura e escrita)

- Folheto

- Resumo

O texto literario e a mida impressa

Intendonalidade comuricativa

Estrateglas de pos-leltura 
- Organização da informação e utlltzaçao das habilidades deserwolvidas em novos contextos de leltura

Funclonamento da língua

Analise estlistica: verbo

Aspectos lingứsticos especticos da construçào do genero

Construçao da textualidade

Identificaça das palawras, sincnimla e idelas-chave em um texto

Intertextualdade: Interdiscursiva, intergenerica e referenclal, tematica

Lexicografia: dicionário, glossário, endclopeda

o concelto de genero textual

Pollssemla

\section{Compreensăo e dlscussăo oral}

Discussao de pontos de vista em textos literários

Expressato de coinices pessoals

SItuaça comunicativa: contexto e Interlocutores

\section{Habilidades}

Espera-se que, tendo como principal referencla as esferas de atividades relacionadas com o estudo, bem como a construça semiotico-cultural do concelto de literatura, em situaçoes de aprendizagem orientadas por atividades de leltura e escrita, os alunos façam uso de diferentes tipos textuals, priorizando, contudo, a tipologla expositiva, e deserwolvam as seguintes habilidades:

- Adaptar textos em diferentes Inguagens, levando em conta aspectos linguísticos, historicos e sodals

- Reconhecer caracteristicas basicas do texto dramatico teatral

- Localizar Informaçces visando a resolver problemas, no campo das instltulçces linguística e literárla, em dicionarios, endiclopedas, gramaticas, internet etc.

- Avaliar a proprla expressão oral cu a alhela durante ou apos situaçôes de interaçao, fazendo, quando possivel, os ajustes necessarios

- Analisar textos que transcrevem a fala ou que fazem Interagir linguagens verbal e náo verbal, tals como as relaçoes entre legenda e fotografla etc. 
- Distinguir as marcas proprlas do texto Iterario e estabelecer relaçces entre o texto literário e o momento de sua produçáo, situando aspectos do contexto historico, soclal e político

- Relaclonar Informaçoes sobre concepçoes artisticas e procedimentos de construçao do texto Iiterario com os contextos de produçào, para atribuir significados de leituras criticas em diferentes sltuaçoes

- Estabelecer relaçoes entre as informaçces do texto lido com outras de conhedmento previo

- Identificar em textos o uso de tempos verbals no ebxo do presente ou do preterito para reconhecer eventos anteriores e posteriores a esses tempos

- Analisar os efeltos semánticos e expressivos producidos pelo uso do verbo

- Utlizar procedimentos Iniclaks para a elaboraça do texto: estabelecer o tema; pesquisar Idelas e dados; planejar a estrutura; formular projeto de texto 


\section{9 série do Ensino Médio \\ Conteúdos}

\section{Esferas de attvidades soclals da linguagem}

A literatura como sistema Intersemiotico

O eu e o cutro: a construção do dlalogo e do conhedmento Leltura e expressăo escrita

Estrateglas de pre-leltura

- Conhecimento sobre o genero do texto e a antecipaça de sentidos a partir de diferentes Indidos

Estruturaça da attvidade escrita

- Projeto de texto

- Construçáo do texto

- Revisto

Texto prescritho (foco: escrita)

- Projeto de texto

Texto argumentatwo (foco: leltura e escrita)

- Estrutura tipologica

Texto exposittwo (foco: leltura e escrita)

- Folder

- Entrevista

Texto Iirico (foco: leltura)

- O poema e o contexto historico

Texto narrativo (foco: leltura)

- o conto

- Comedia e tragedia (semehanças e diferenças)

As entrevistas e a midla impressa

Relaçoes entre literatura e outras expressces da Arte Intendonalidade comuricativa

Estrategas de pos-leltura 
- Organizaçao da informação e utillzaçao das habilidades deserwolvidas em nowos contextos de leltura.

\section{Funclonamento da língua}

Analise estlistica: verbo, adjetivo, substantivo

Aspectos linguísticos especticos da construçào do genero

Construçao da textualidade

Construçao linguistica da superficle textual: coesto

Identificaçao das palawras, sinonimla e Idelas-chave em um texto

Intertextualdade: Interdiscursiva, Intergenerica, referenclal e tematica

Interserrioticidade

Lexicografia: dicionărio, glossario, enciclopeda

Relaçoes entre os estudos de Iteratura e linguagem

\section{Compreensăo e discussão oral}

Discussao de pontos de vista em textos literários

Expressto de cpinices pessoals

Hetero e autoavallaça

\section{Habilidades}

Espera-se que, tendo como princlpal referencla as esferas de atMdades relaclonadas com o estudo, bem como a construçáo semlotico-cultural do concelto de literatura, em situaçoes de aprendizagem orlentadas por athidades de leltura e escrita, os alunos façam uso de dferentes tipos textuals, priorizando, contudo, a tipologia expositiva, e desenwolvam as seguintes hablidades:

- Construir um concelto de Literatura a partir de sua dimensło semiotica, compreendendo-o como sistema intersemiotico

- Analisar, em um texto, os mecarismos lingústicos uttlizados na sua construçao

- Reconhecer diferentes elementos Internos e externos que estruturam uma entrevista, apropriando-se deles no processo de construçao do sentido

- Reconhecer marcas da alteridade do coenunclador presentes no texto

- Identificar e explicar as diferenças entre comedla e tragedla 
Lingus

Portuguesa

Cumiculo do Estado de SSo Paulo

- Reconhecer, em contos, entrevistas e poemas, marcas linguisticas que singularizam os diferentes generos

- Identificar os efeltos de sentido resultantes do uso de determinados recursos expressivos, em contos, entrevistas e poemas

- Reconhecer caracteristicas bassicas do poema lirico

क - Posiclonar-se criticamente dlante do texto do outro, defendendo ponto de vista ccerente a partir de argumentos

- Analisar os efeltos semánticos e expressivos produzidos pelo uso das diferentes classes morfologicas e discursivas: verbo e conectores 
Lexicografla: didonario, glossario, enciclopedla

Rebaçoes entre cs estudos de literatura e Inguagem

Compreensăo e dlscussáo oral

Discussao de pontos de vista em textos Iterarios

Expressto de opinices pessoak

Estrateglas de escuta

\section{Habilidades}

Espera-se que, tendo como princlpal referenda as esferas de atividades reladonadas com o estudo, bem como a construçao semiotico-cultural do concelto de literatura, em sltuaçoes de aprendizagem orlentadas por athidades de leitura e escrita, os alunos façam uso de diferentes tipos textuals, priorizando, contudo, a tipologla exposkça, e deserwolvam as seguintes habilidades:

- Analsar os efeltos semánticos e expressivos produzidos pelo uso das diferentes classes morfologicas: verbo, artigos e numerals

- Posiclonar-se criticamente diante do texto do outro, defendendo ponto de vista coerente a partir de argumentos

- Identificar e analisar mecarismos de ruptura no texto narrativo tradiclonal

- Reconhecer as principals diferenças e semelhanças entre generos literarios narratwos

- Reconhecer e analsar a expressao literárla popular, es tabelecendo dialogos Intertextuals com a produçáo literarla erudita

- Analisar os efeitos semánticos e expressivos produridos pelo uso das diferentes classes morfologicas: verbo, pronomes, artigos e numerals

- Construir sentido pela cortparaça entre textos a partir de diferentes relaçoes Intertextuals 
ANEXO K - Quadro de conteúdos e habilidades em Língua Portuguesa - $2^{\mathrm{a}}$ série $\mathrm{EM}(C L P)$

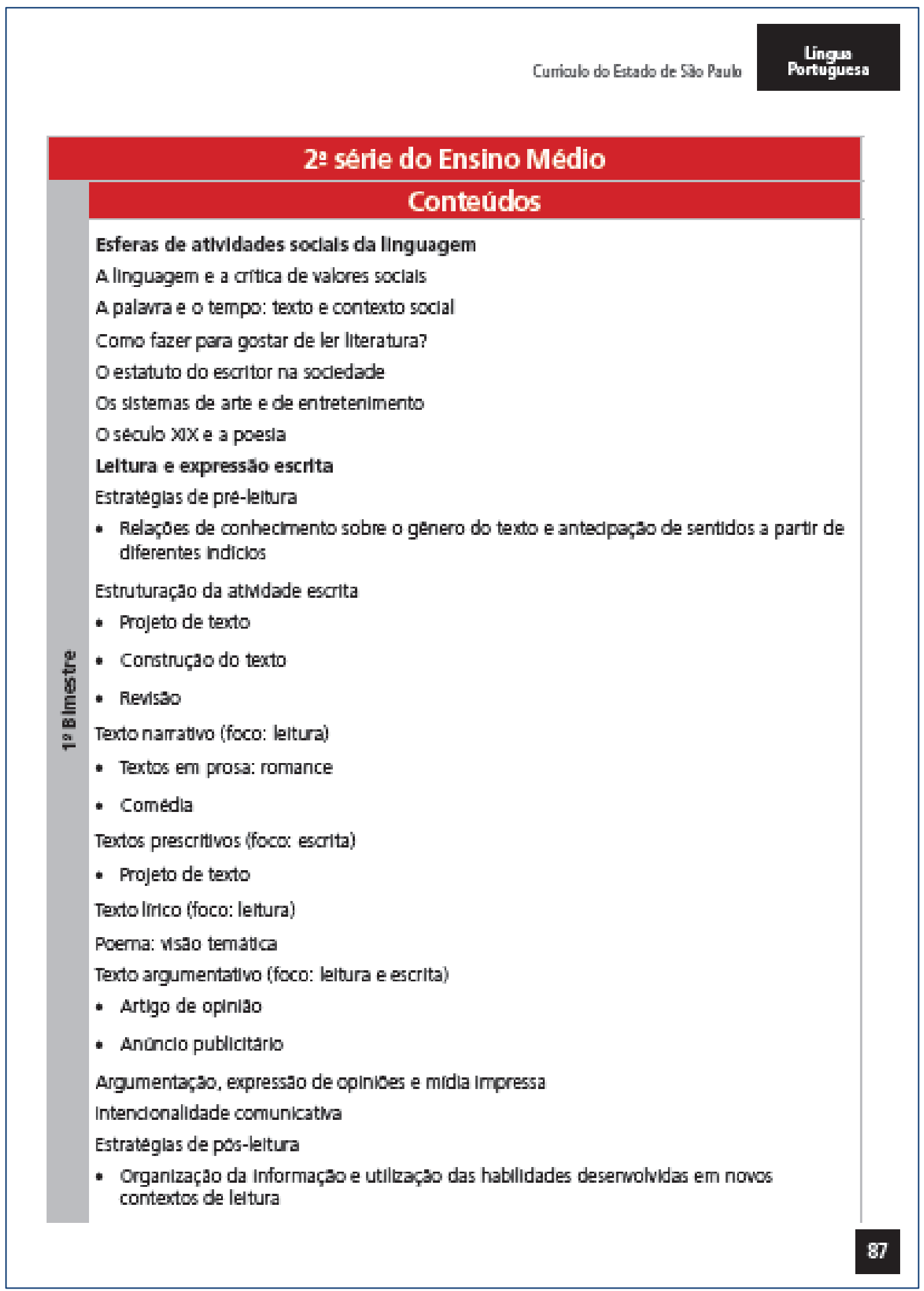


Funclonamento da língua

Analse estilistica: conecthos

Aspectos linguisticos especificos da construça da textualidade

Construça linguistica da superficle textual: uso de conectores

Cocrdenaçăo e subordinaçăo

Formaça do genero

Intertextualidade: Interdiscursiva, Intergenerica, referenclal e tematica

Lexicografia: diclonario, glossario, enciclopedla

Periodos simples e composto

Valor expressivo do periodo simples

Compreensăo e discussăo oral

Discussao de pontos de vista em textos crlativos (publicitario)

\section{Habilidades}

Espera-se que, pelo uso de diferentes tipos textuals, tendo como principal referenda as esferas de attidades relacionadas com a midla, bem como as relaçces temporaks entre linguagem e Individuo, em situaçces de aprendzagem orientadas por atividades de leitura e escrita, e priorizando a tipologia argumentativa, os estudantes deserwolvam as seguintes habilidades:

- Distinguir as diferenças entre leitura de distraçäo e leitura literária, atentando para o valor estetico do texto ficcional

- Sintetizar ophioes

- Distinguir enundados objetivos e enunclados subjettwos

- Reconhecer, em textos, os procedimentos de corwendmento utilizados pelo enundador

- Reconhecer o Impacto social das diferentes tecnologlas de comunicaçăo e nformação

- Analisar, em textos de variados géneros, elementos sintaticos utilizados na sua construçáso

- Analisar os efeltos semánticos e expressivos, em um texto, produzidos tanto pelo uso de periodos simples ou compostos como pelo uso das conjunçoes

- Analisar os efeltos semánticos e expressivos produzidos pela cocordenaçáo e subordinaçáo de periodos na construçáo de textos argumentativos

- Distinguir notida de artigo de cpiniso

- Relacionar -em artigos de opiniao e anundos publicitarios - cpinioes, temas, assuntos, recursos linguísticos, identificando o dialogo entre as idelas e o embate dos interesses existentes na sodedade

- Reconhecer as caracteristicas que definem o genero literario romance

- Estabelecer relaçoes logico-discursivas, analısando o valor argumentattwo dos conectivos 


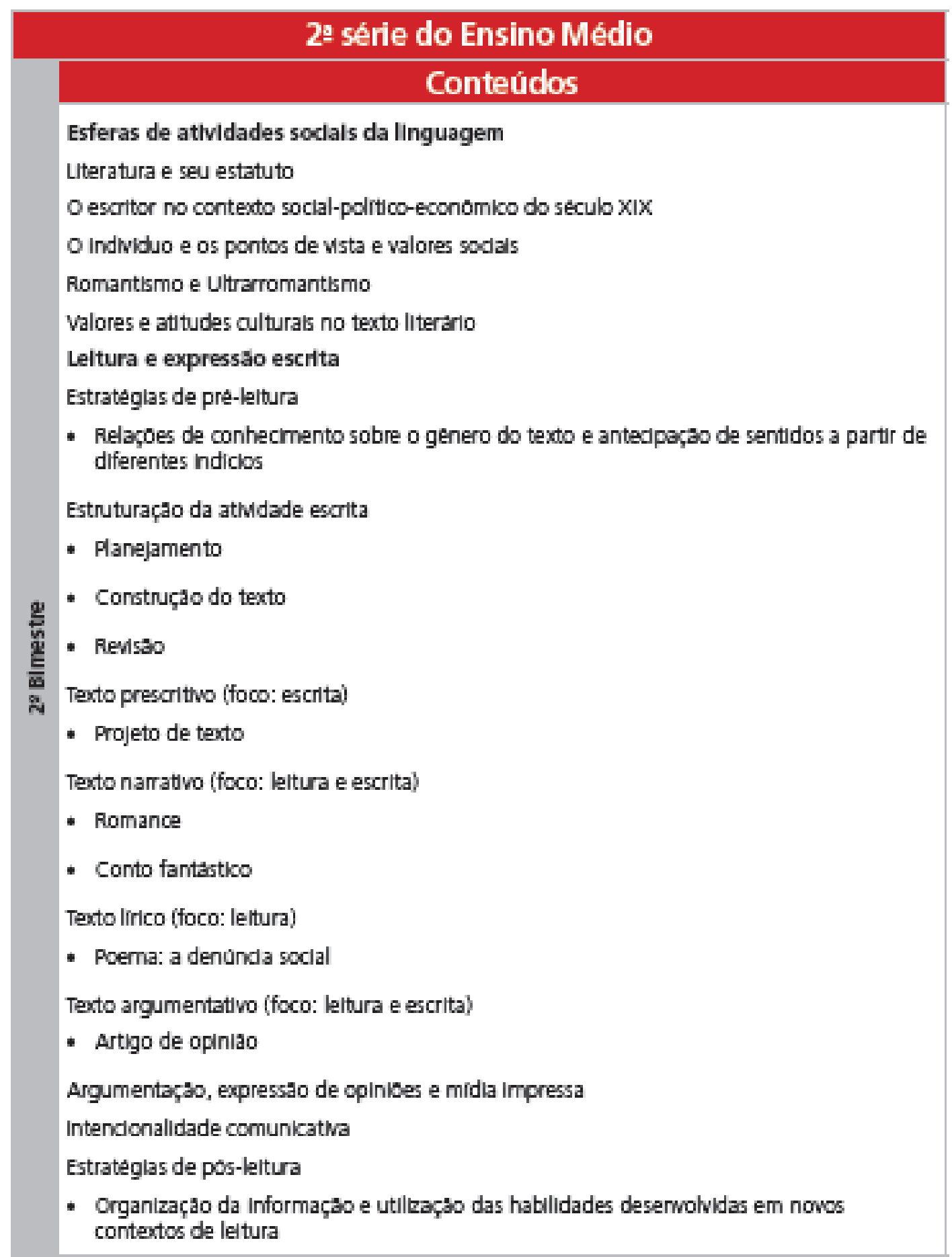


Funclonamento da lingua

- Analise estilistica: adverblo e metonimla

- Aspectos linguísticos especificos da construçá do genero

- Coesáo e coerenda com vistas a construçao da textualidade

identificaçao das palauras e idelas-chave em um texto

Interaça entre elementos literarios e lingứsticos

Intertextualidade: Interdiscursiva, Intergenerica, referenclal, tematica

Lexicografia: didonário, glossario, enciclopedla

Processos interpretativos inferenclais: metafora

Compreensăo e dlscussăo oral

Concatenaçao de Idelas

Discussao de pontos de vista em textos cpinatwos

Expressto de opinices pessoals

\section{Habilidades}

Espera-se que, pelo uso de diferentes tipos textuals, tendo como principal referencla as esferas de attidades relacionadas com a midla, bem como as relaçces temporals entre linguagem e Indwiduo, em situaçces de aprendzagem orientadas por attvidades de leltura e escrita, e priorizando a tjpologla argumentativa, os estudantes deserwolvam as seguintes habilidades:

- Inferr o sentido de palavras ou expressces en textos literarios do seculo XX, considerando o contexto que as envolve

- Contextualizar historica e sodalmente o texto literário produzido no seculo XX

- Reconhecer dferentes elementos que estruturam o texto narratwo (personagens, marcadores de tempo e de localizaçao, sequencla logica dos fatos) na construçáo do sentido do romance e do conto do seculo XXX, apropriando-se deles no processo de elaboraçăo do sentido

- Formular opiniao sobre detemnado fato artistico, clentfico ou soclal, defendendo-a por melo de argumentaçăo logica 
- Estabelecer relaçao entre a tese e os argumentos apresentados para defende-la ou refuta-la

- Inferir tese, tema ou assunto principal nos generos textuals: artigo de cpiniao, romance, conto fantastico e poema

- Reconhecer recursos prosodicos e expressmos frequentes em texto poetico (ima, nitmo, assonanda, aliteraçao), estabelecendo relaçoes entre eles e o tema do poema

- Reconhecer o texto literario produzido no seculo XXX como fator de promoçao dos direltos e valores humanos atualzavels na contemporaneldade

- Identificar o valor semantico e expressivo do adverblo na construçáo coestva de um texto

- Identificar o valor expressivo da metafora e da metonímla na construçáo coesiva de um texto

- Confrontar um texto produzido antes do seculo $x \propto$ com outros textos, opinioes e Informaçoes, posiclonando-se critucamente, levando em conta os diferentes modos de ver o mundo presente

- Diferendar Idelas centrals e secundarlas de um texto 


\section{2 série do Ensino Médio}

\section{Conteúdos}

Esferas de atlvldades soclals da linguagem

Ética, semualidade e linguagem

Literatura e seu estatuto

O escritor no contexto soclal-político-economico do seculo XIX

As propostas pos-romanticas e a literatura realista e naturdista

Leltura e expressăo escrita

Estrateglas de pre-leltura

- Relaçoes de conhecimento sobre o genero do texto e antedpaçao de sentidos a partir de diferentes indiclos

Estruturaçăo da at/Midade escrita

- Planejamento

- Construça do texto

- Revisao

Texto prescritivo (foco: escrita)

- Projeto de texto

Texto expositivo (foco: leltura e escrita)

- Reportagem

- Correspondencla

Texto narrattvo (foco: leltura)

- O símbolo e a moral

Texto lírico (foco: leltura)

- O símbolo e a moral

- Poema: a ruptura e o dalogo com a tradiça

Relato (foco: escrita)

- Ensalo ou perfil bicgrafico 
A expressáo de idelas e corhedmentos e a midla impressa

Intendonalidade comunicativa

Estrateglas de pos-leltura

- Organização da Informaçăo e utillzaçào das habilidades deserwolvidas em novos contextos de leltura

\section{Funclonamento da língua}

A sequendalizaça dos parágrafos

Analise estlistica: preposiçąo

Aspectos lingứsticos especticos da construçà do genero

Coesao e coerencla com vistas a construçao da textualdade

Intertextualdade: Interdiscursiva, Intergenerica, referendal, ternatica

Lexicografia: dicionário, glossario, endclopeda

\section{Compreensăo e discussăo oral}

Concatenaça de idelas

Intenclonalidade comunicativa

Discussio de pontos de vista em textos opinativos

के

Hetero e autoavallaçăo

\section{Habilidades}

Espera-se que, pelo uso de diferentes tipos textuals, tendo como princlpal referenda as esferas de attvidades relacionadas com a mida, bem como as relaçoes terncorals entre linguagem e individuo, em sltuaçoes de aprendizagem orlentadas por athidades de leltura e escrita, e pricrizando a tipologla argumentativa, os estudantes desenvolvam as seguintes habilidades:

- Relacdonar diferentes produçoes textuals aos valores proprios da sexualidade e contemporaneldade

- Relacionar a produçà textual presente a herança cultural acumulada pela língua portuguesa nos processos de continuldade e ruptura

- Organizar adequadamente os paragrafos de um texto visando a atingir a proposta enunclativa 
Lingus

Portugues

Curriculo do Estado de SSo Paulo

- Elaborar estrateglas de produçao de textos expositivos e argumentativos

- Inferir tese, tema ou assunto principal nos diferentes generos: reportagem, correspondencla, poema, ensalo e/ou perfil biografico

- Concatenar Idelas na estruturaçao de um texto argumentativo

- Relacionar a construçáo da subjetividade a expressao literaria em textos do seculo XX

- Analsar e revisar o proprio texto em funçáo dos objetwos estabelecidos, da intençaso comuricativa e do leltor a que se destina

- Analsar os efeltos semanticos e expressmos produaddos pelo uso dos elementos de linguagem (preposiçăo e conectivos) em textos varlados

- Usar adequadamente os conectores na construçao coesiva de um texto 


\begin{tabular}{|c|c|}
\hline & 2e série do Ensino Médio \\
\hline & Conteúdos \\
\hline & Esferas de atlvidades soclals da linguagem \\
\hline & Literatura e realidade soclal \\
\hline & Comunicaça, socledade e poder \\
\hline & Ruptura e dlalogo entre linguagem e trad çă \\
\hline & Leltura e expressăo escrita \\
\hline & Estrateglas de pre-leltura \\
\hline & $\begin{array}{l}\text { - Relaçoes de conhecimento sobre o genero do texto e antecipaçáo de sentidos a partir de } \\
\text { diferentes indicios }\end{array}$ \\
\hline & Estruturaçao da athidade escrita \\
\hline & - Planejamento \\
\hline & - Construçao do texto \\
\hline$\stackrel{g}{\underline{H}}$ & - Revisao \\
\hline$\underline{\underline{E}}$ & Texto literario (foco: leltura) \\
\hline & - Conto: a ruptura com a trad çá \\
\hline & - Pcerna: subjethidade e cojettividade \\
\hline & Texto expositivo (foco: leitura e escrita) \\
\hline & - Entrevista \\
\hline & Relato (foco: leltura e escrita) \\
\hline & - Reportagem \\
\hline & Texto Informativo (foco: leltura e escrita) \\
\hline & - Folder ou prospecto \\
\hline & A expressto de opirioes pela institulça jornalistica \\
\hline & Intendonalidade comunicativa \\
\hline & Estrateglas de pos-leltura \\
\hline & $\begin{array}{l}\text { - Organizaçao da Informaça e utillzaça das habilidades deserwolvidas em nowos } \\
\text { contextos de leitura }\end{array}$ \\
\hline
\end{tabular}


Funclonamento da língua

Anal|se estilistica: craçoes coordenadas e subcrdnadas

A sequenclalização dos paragrafos

Conhecimentos linguisticos e de genero textual

Coesa a coerenda com vistas a construção da textualidade

Intertextualidade: Interdiscursiva, Intergenerica, referenclal e ternatica

Lexkcografia: didonario, glossario, enciclopedla

Compreensăo e discussăo oral

Concatenaçâo de Idelas

Discussio de pontos de vista em textos ophativos

Estrateglas de escuta

\section{Habilidades}

Espera-se que, pelo uso de diferentes tipos textuals, tendo como princlpal referencla as esferas de attidades relacionadas com a midla, bem como as relaçces temporals entre linguagem e indivduo, em situaçces de aprendzagem orlentadas por atuvidades de leitura e escrita, e priorizando a tipologla argumentativa, os estudantes deserwokvam as seguintes habilidades:

- Relacionar a produçáo textual presente a herança cultural acumulada pela língua portuguesa nos processos de continuldade e ruptura

- Relacionar a dimensáo persuasiva da Inguagem as diferentes vivendas sodals visando a polemizar preconceltos e incoerendas

- Concatenar adequadamente as dferentes frases de um texto visando a construçăo da textualidade

- Identficar, em textos Iiterarios dos seculos XX eXX as relaçoes entre tema, estilo e contexto de produçäo

- Relacionar o genero textual conto a construçäo de expectativas de leitura

- Reconhecer processos linguisticos para romper com a tradiça literarla anterior ao seculo XXX, na Uteratura

- Analisar o uso da linguagem na produçăo de entrevistas em nterface com a construção da Identidade socdal

- Analisar os efeitos semánticos e expressivos produzidos pelo uso de oraçoes coordenadas e subordinadas em textos variados

- Analisar os efeitos semánticos e expressivos produzidos pelo uso de conectores em entrevistas

ANEXO L - Quadro de conteúdos e habilidades em Língua Portuguesa - 3ª série $\mathrm{EM}(C L P)$ 


\section{3ొ série do Ensino Médio}

\section{Conteúdos}

Esferas de ativldades soclals da linguagem

A literatura e a construçăo da modernidade e do moderno

LInguagem e o desenvolwmento do olhar critico

Leltura e expressăo escrita

Estrateglas de pre-leltura

- Relaçoes de conhecrmento sobre o genero do texto e antedpaçao de sentidos a partir de diferentes ndicios

Estruturaçăo da at/Midade escrita

- Planejamento

- Construçào do texto

- Revisao

2. Textos prescritivos (foco: escrita)

- Projeto de texto

a Texto narrattvo (foco: leltura e escrita)

- A narrativa moderna

- Cartum ou HQ

Texto lírico (foco: leltura)

- A lírica moderna

Texto argumentativo (foco: leltura e escrita)

- Resenha crituca

Argumentaça, critica e midia impressa

Intencionalidade comunicativa

Estrateglas de pos-leltura

- Organização da informação e utilizaçaso das habilidades deserwolvidas em nowos contextos de leltura 
Funclonamento da lingua

A Lingua Portuguesa e os exames de acesso ao Ensino Superior

Aspectos formals do uso da língua: ortografia e concordancla

Aspectos linguisticos especificos da construçáo do genero: uso do numeral

Categorlas da narratwa: personagem, espaço e enredo

Construçao da textualidade

identificaçào das palawras e idelas-chave em um texto

Intertextualidade: Interdiscursiva, Intergenerica, referencial e ternatica

Linguagem e adequaça vocabular

valor expressivo do vocativo

o problema do eco em textos escritos

Resoluça de problemas de oralidade na produçao do texto escrito

Compreensăo e discussáo oral

A oralidade nos textos escritos

Discussao de pontos de vista em textos Iterarios

A Importáncla da tomada de turno

\section{Habilidades}

Espera-se que, tendo como principal referencla a esfera de at/Mdade profissoes e o concelto semlotico-cultural de modernidade, em situaçoes de aprendzagem orlentadas por attildades de leitura e escrita e centradas em diferentes tipos textuals, priorizando, contudo, a tipologla argumentativa, os estudantes desenvolvam as seguintes habilidades:

- Reladonar as culturas produzidas, en lingua portuguesa, en Portugal, na África e no Brasl

- Construir um concelto de modernidade que explique fenomenos culturak e literarios conterrporaneos, relaclonando, a partir desse concelto, as diferentes produçces culturals conterrporaneas

- Relaclonar diferentes produçoes artisticas e culturals contemporaneas com outras obras do passado, procurando aproxdmaçoes de terna e sentido

- Analisar os efeitos semanticos e expressivos produridos pelo uso do vocattio em tertos e frases

- Resolver problemas de oralidade na produça do texto escrito visando a adequar o texto a intenclonalidade comunicativa

- Adequar o registro escrito e cral a situaçoes formak de uso da Inguagem

- Identficar e analisar caracteristicas proprlas da linguagem literaria da modernidade

- Identficar a tese e Idelas-chave em um texto argumentativo 


\section{3: série do Ensino Médio}

\section{Conteúdos}

Esferas de attvidades soclals da linguagem

A critica de valores sodals no texto literario

Adequaça Inguistica e ambiente de trabalho

A literatura e a construçà da modernidade e do Modernismo

A lingua portuguesa e o mundo do trabalho

Leltura e expressåo escrita

Estrateglas de pre-leltura

- Relaçoes de corhedmento sobre o genero do texto e antedpaçáo de sentidos a partir de diferentes Indiclos

Estruturaça da attividade escrita

- Planejamento

- Construção do texto

- Revisáo

Texto prescritho (foco: escrita)

- Projeto de texto

Texto narrativo (foco: leltura)

- Romance de tese

Texto Iricico (foco: leltura)

- Poesla e critica sodal

Texto argumentatwo (foco: escrita)

- Dissertaçáo escolar

Mundo do trabalho e midla Impressa

Intenclonalidade comuricativa

Estrateglas de pos-leltura

- Organização da informaçăo e utilização das habilidades desenvolidas em nowos contextos de leltura

Funclonamento da língua

Adequaçao Ingulstica e trabalho

Analse estilistica: nivel sintatico 
Conhecimentos linguisticos e de genero textual

Construçao da textualidade

Construça linguistica da superficle textual: paralelismos, coordenaçäo e subordinaça

Estrutura sintatica e construçâo da tese

Intertextualidade: interdiscursiva, intergenerica, referenclal e tematica

Lexicografla: diconario, glossario, enciclopedla

Compreensăo e discussăo oral

Expressto de opinices pessoals

identficaçąo de estruturas e funçoes

\section{Habilidades}

Espera-se que, tendo como principal referencla a esfera de athdade profissoes e o concelto semiotico-cultural de modernidade, em situaçoes de aprendizagem orlentadas por atividades de leltura e escrita e centradas em diferentes tipos textuals, pricrizando, contudo, a tipologla argumentativa, os estudantes desenvolvam as seguintes habilidades:

- Reconhecer diferentes elementos que estruturam o texto narratwo (personagens, marcadores de tempo e de localizaçao, sequencla logica dos fatos) visando a resolver questoes de acesso ao Ensino Superior

- Usar adequadamente a norma -padr ao formal da lingua portuguesa na elaboraçao de respostas e textos dissertativos que atendam as solidtaçes de exames de acesso ao Ensino superior ekou seleçces e entrenistas de emprego

- Contextualizar historica e sodalmente o texto literario

- Projetar dissertaçces escolares

- Relacionar contexto soclocultural a uma deteminada obra Iiterarla produzida na segunda metade do seculo $x$

- Analsar o paraleltsmo, particularmente como ele se marifesta na construçáo dos periodos do texto nos processos de coordenaçăo e subordinaçăo

- Identficar, no texto, marcas de uso de variaçäo Inguistica

- Comparar as caracteristicas de diferentes generos sobre a apresentaçao de um mesmo terna 
Funclonamento da língua

Conhecimentos lingứsticos e de genero textual

Construçao da textualidade

Construçăo linguistica da superficle textual: reformulaçăo, parafrase e estilizaçao

Intertextualidade: Interdiscursiva, Intergenerica, referenclal e tematica

Lexicografia: didonario, glossario, enciclopedia

o diche e o chavao

Compreensăo e discussăo oral

Expressto de opirices pessoals

Hetero e autoaral laçaso

\section{Habilidades}

Espera-se que, tendo como principal referencla a esfera de atimdade profissoes e o concelto semiotico-cultural de modernidade, em situaçoes de aprendzagem orlentadas por atividades de leitura e escrita e centradas em diferentes tipos textuals, priorizando, contudo, a tipologla argumentativa, os estudantes desenvolvam as seguintes habilidades:

- Considerar Indicios de valores presentes na contemporaneidade manifestos na urdidura textual

- Analisar as intençoes enunclativas dos textos literarios na escolha dos temas, das estruturas e dos estllos, como procedmentos argumentativos

- Elaborar a revisao de texto produzido seguindo procedimentos aprendidos na serie

- Relacionar, como realdade cultural lusofona, as produçoes, en lingua portuguesa, na Africa e no Brasl|

- Identficar o papel de categorlas da enunclaça - pessca, tempo e espaço- na construçáo de sentidos para o texto

- Usar conhecimentos de tercelros (citaçao) na produçao de projeto de texto proprio, mantendo autorla

- Relaclonar, em produça textual, informaçoes velculadas pela mídla impressa sobre a esfera de atimdades "trabalho e emprego" na produçao de um texto dissertativo

- Analisar criticamente as relaçoes entre poesla da modernidade e a construçao do mundo atual

- Identficar o valor discursivo e expressivo da estillzaçao, da parodia e da reformulaçäo na construçáa do sentido de um texto

- Relaclonar criticamente, na produçà de um texto de acesso ao Ensino Superior, Informaçoes das diferentes áreas do saber. Flosofla, Economia, Soclologla, Literatura, Arte, entre cutras 


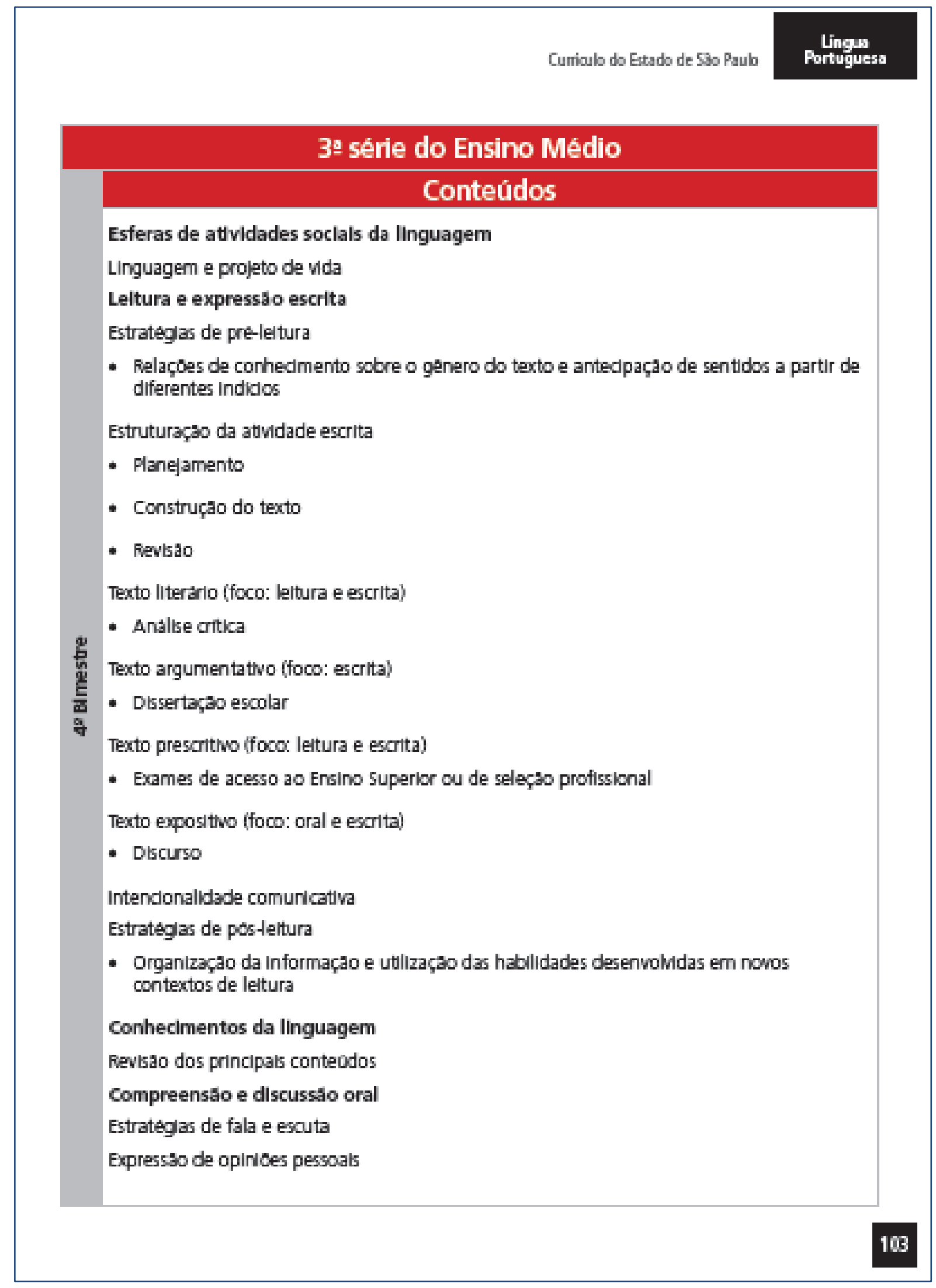




\section{Habilidades}

Espera-se que, tendo como principal referencla a esfera de atwidade profissoes e o concelto semiotico-cultural de modernidade, em sltuaçoes de aprendizagem orlentadas por athidades de leltura e escrita e centradas em diferentes tipos textuals, priorizando, contudo, a tipologla argumentativa, os estudantes deserwolvam as seguintes hablidades:

- Posidonar-se criticamente dlante da realidade fazendo interagir conceltos, valores Ideologicos e elementos linguisticos

- Considerar indicios de valores presentes na conterrporaneidade manifestos na urdidura textual

- Analisar as intençoes enundativas dos textos literarios na escolha dos temas, das estruturas e dos estilos, como procedimentos argumentatwos

- Localizar Informaçces relevantes do texto para soluclonar determinado problema apresentado

- Identificar os elementos pertinentes a um projeto de vida mantendo, por melo da atividade linguistica, o sentido de interdependencla com o mundo

- Mobilizar informaçces, conceltos e procedimentos na produço escrita de um projeto de vida

- Identificar e avaliar as caracteristicas proprlas da apresentaça de um discurso de orador

- Reladonar corhedmentos do uso da norma-padráo da Ingua portuguesa a construçáo de um discurso de orador

- Avaliar as habilidades do cutro seguindo citerios especificos preestabelecidos

- Reladonar criticamente, na produçăo de um texto, Informaçces das diferentes areas do saber: Fllosofla, Economla, Soclologla, Literatura, Arte, entre outras 